\title{
पBERㅇำ
}

\section{Alicja Niedźwiecka}

\section{Analiza interakcji dziecko-rodzic}

Wprowadzenie dla studentów,

klinicystów i badaczy

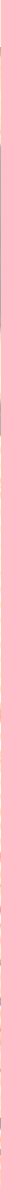


Alicja Niedźwiecka

Analiza interakcji dziecko-rodzic

Wprowadzenie dla studentów, klinicystów i badaczy 

Alicja Niedźwiecka

Analiza interakcji dziecko-rodzic

Wprowadzenie dla studentów, klinicystów i badaczy 
Alicja Niedźwiecka iD https://orcid.org/oooo-0002-7485-846X

Analiza interakcji dziecko-rodzic. Wprowadzenie dla studentów, klinicystów i badaczy

Recenzenci:

prof. dr hab. Marta Białecka-Pikul (Uniwersytet Jagielloński)

dr hab. Ludwika Wojciechowska, prof. UZ (Uniwersytet Zielonogórski)

Projekt okładki:

Dominika Karaś

Ilustracja na okładce:

pixabay.com

Korekta językowa:

Małgorzata Najderska

Skład i łamanie:

Justyna Harasimczuk

Publikacja jest udostępniona na licencji Creative Commons Uznanie autorstwa 4.0 Treść licencji jest dostępna na stronie: https://creativecommons.org/licenses/ by/4.0/

Publikacja finansowana ze środków Wydziału Psychologii Uniwersytetu Warszawskiego przyznanych przez MNiSW w formie subwencji na utrzymanie i rozwój potencjału badawczego w roku 2021 (501-D125-01-1250000 zlec*5011000632)

Warszawa: Wydawnictwo Liberi Libri, 2021

www.LiberiLibri.pl

ISBN: 978-83-63487-53-9

DOI: 10.47943/lib.9788363487539 


\section{SPIS TREŚCI}

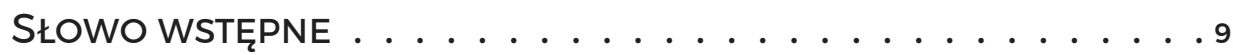

\section{CZĘŚĆ I}

1. DLACZEGo ANALIZA INTERAKCJI? . . . . . . . . . . . . . . . . 13

1.1 MIEJSCE ANALIZY INTERAKCJI DZIECKO-RODZIC W DIAGNOZIE PSYCHOLOGICZNEJ I W BADANIACH NAUKOWYCH . . . . . . . . . 13

1.1.1. ANALIZA INTERAKCJI DZIECKO-RODZIC W PROCESIE DIAGNOZY PSYCHOLOGICZNEJ . . . . . . . . . . . . 15

1.1.2. ANALIZA INTERAKCJI DZIECKO-RODZIC W BADANIACH NAUKOWYCH . . . 16

1.2. ROLA TEORII PSYCHOLOGICZNYCH W ANALIZIE INTERAKCJI

DZIECKO-RODZIC. . . . . . . . . . . . . . . 17

1.3. INTERAKCYJNY KONTEKST ROZWOJU. . . . . . . . . . . . . . 20

2. ANALIZA INTERAKCJI JAKO NARZĘDZIE DIAGNOSTYCZNE

I BADAWCZE . . . . . . . . . . . . . . . 25

2.1. ANALIZA INTERAKCJI KROK PO KROKU . . . . . . . . . . . . . 25

2.1.1. SUROWY OPIS . . . . . . . . . . . . . . . . . 26

2.1.2. OPIS WŁASNYCH ODCZUĆ . . . . . . . . . . . . 27

2.1.3. OPIS OCÓLNY . . . . . . . . . . . . . . . . . . 28

2.1.4. OPIS WYBRANYCH ZACHOWAŃ LUB ICH SEKWENCJI . . . . . . . . 29

2.1.5. NADAWANIE ZNACZENIA WYBRANYM ZACHOWANIOM . . . . . . . . 30

2.1.6. INTEGRACJA INFORMACJI . . . . . . . . . . . . . . 32

2.1.7. OSTATECZNA INTERPRETACJA. . . . . . . . . . . . . . . 34

2.2. UCZESTNICY INTERAKCJI . . . . . . . . . . . . . . . . . . . . . . . . . . . . . . . . .

2.2.1. POZIOM OSOBY: DZIECKO . . . . . . . . . . . . . . . . . 35

2.2.2. POZIOM OSOBY: RODZIC. . . . . . . . . . . . . . . . . . . 39

2.2.3. POZIOM OSÓB: DIADA DZIECKO-RODZIC . . . . . . . . . . . 43

2.2.4. POZIOM OSÓB: TRIADA DZIECKO-RODZICE . . . . . . . . . . . . 49

2.3. SCHEMATY OCEN STOSOWANE W ANALIZIE INTERAKCJI

DZIECKO-RODZIC. . . . . . . . . . . . . . . 50

2.3.1. MIKRO-I MAKROANALIZA INTERAKCJI . . . . . . . . . . . . 50

2.3.2. WYBRANE SCHEMATY OCENY STOSOWANE W ANALIZIE INTERAKCJI . . . 52

2.3.2.1. OCENA ZACHOWANIA RODZICA . . . . . . . . . . . . 53

2.3.2.1.1. SKALE WRAŻLIWOŚCI MACIERZYŃSKIEJ AINSWORTH. . . . . . 53

2.3.2.1.2. Q-SET ZACHOWAŃ MACIERZYŃSKICH . . . . . . . . 54

2.3.2.1.3. SKALE DOSTĘPNOŚCI EMOCJONALNEJ . . . . . . . . . 54

2.3.2.1.4. MACIERZYŃSKI STYL INTERAKCYJNY . . . . . . . . . . 55 


\section{SPIS TREŚCI}

2.3.2.1.5. OCENA ZACHOWAŃ RODZICIELSKICH PODCZAS CZYTANIA

DZIECKU . . . . . . . . . . . . . . . 55

2.3.2.1.6. KWESTIONARIUSZ RESPONSYWNOŚCI MACIERZYŃSKIEJ ••56

2.3.2.1.7. OCENA JAKOŚCI INTERAKCJI OPIEKUN-DZIECKO DLA

NIEMOWLĄT I MAŁYCH DZIECI . • • • • • • • • • . 57

2.3.2.2. INTERAKCJE DIADYCZNE . . . . . . . . . . . . . . . . 57

2.3.2.2.1. PROCEDURA KAMIENNEJ TWARZY I FAZY MONADYCZNE • • • . 57

2.3.2.2.2. KODOWANIE STANÓW WSPÓLNEGo ZAANGAŻOWANIA • • • • . 58

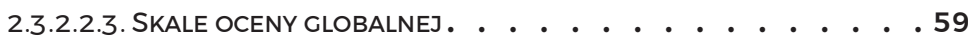

2.3.2.2.4. SYSTEM DO KODOWANIA INTERAKCJI DIADYCZNYCH

RODZIC-DZIECKO . . . . . . . . . . . . 60

2.3.2.2.5. KODOWANIE MIKROANALITYCZNE. . . . . . . . . . 60

2.3.2.3. INTERAKCJE TRIADYCZNE. . . . . . . . . . . . . . . 61

2.3.2.3.1. LOZAŃSKA ZABAWA TRIALOCOWA. . . . . . . . . . . 61

2.3.2.3.2. TRIADYCZNE I DIADYCZNE KOLO INTERAKCYJNE • • . • . • . 62

2.3.2.3.3. KODOWANIE ZACHOWAŃ INTERAKCYJNYCH . . . . . . . . . 63

2.3.2.4. INTERAKCJE CZTERECH LUB WIĘCEJ OSÓB . . . . . . . . • . . . . 63

2.3.2.5. NARZĘDZIA DLA DZIECI Z RODZINNYM RYZYKIEM WYSTĄPIENIA

ZABURZEŃ ZE SPEKTRUM AUTYZMU LUB OBJAWAMI AUTYZMU . . . . . . 64

2.3.2.5.1. MANCHESTERSKIE NARZĘDZIE DO OCENY JAKOŚCI

INTERAKCJI OPIEKUN-DZIECKO. . . . . . . . . . . 64

2.3.2.5.2. MIARA KOMUNIKACJI DIADYCZNEJ W AUTYZMIE . • . . . . 65

2.3.2.5.3. OCENA RADOŚCI ZABAWY. . . . . . . . . . . . 65

2.3.2.5.4. SKALA DO OCENY INTERAKCJI SPOŁECZNYCH . . • . . . . 66

2.3.3. AUTOMATYCZNE ZBIERANIE DANYCH . • . . . . . . . . • • . . 66

\section{CZĘŚĆ II}

\section{ROZWÓJ KOMPETENCJI INTERAKCYJNYCH W PIERWSZYM} ROKU ŻYCIA . . . . . . . . . . . . . . . . . . . . . 70

3.1. INTERAKCJE TWARZĄ W TWARZ . . . . . . . . . . . . . 71

3.2. MIMICZNA EKSPRESJA EMOCJI . . . . . . . . . . . . . . . . 76

3.3. KOMUNIKOWANIE SIĘ ZA POMOCĄ WIELU ZMYSŁÓW . . . . . . . . . 79

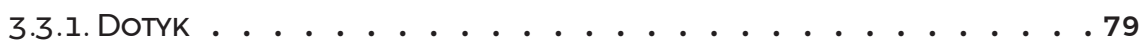

3.3.2. StUCH I MOWA. . . . . . . . . . . . . . . 81

3.3.3. WielozMYStOWOŚĆ . . . . . . . . . . . . . . 83

3.4. INTERAKCJE Z WYKORZYSTANIEM PRZEDMIOTÓW I ODNIESIEŃ

DO OTOCZENIA. . . . . . . . . . . . . . . . . 84

4. PRZEGLĄD BADAŃ NAD INTERAKCJAMI DZIECI

Z ZABURZENIAMI ROZWOJU . . . . . . . . . . . . . . . . 91

4.1. DZIECI Z ZABURZENIAMI ZE SPEKTRUM AUTYZMU. . . . . . . . . . . 91

4.2. DZIECI ZZESPOŁEM DOWNA . . . . . . . . . . . . . 102

4.3. DZIECI Z NIEPEŁNOSPRAWNOŚCIĄ INTELEKTUALNĄ . . . . . . . . 107 


\section{SPIS TREŚCI}

4.4. DZIECI Z ZESPOŁEM NADPOBUDLIWOŚCI PSYCHORUCHOWEJ

Z DEFICYTEM UWAGI . . . . . . . . . . . . . . 109

4.5. DZIECI Z ZABURZENIAMI ZACHOWANIA . . . . . . . . . . . . 114

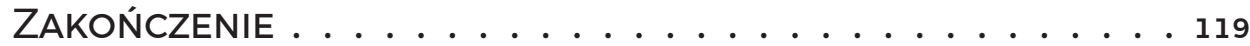

BIBLIOGRAFIA . . . . . . . . . . . . . . 120

ZAŁĄCZNIK A: KARTA OCENY INTERAKCJI DZIECKO-RODZIC . . . . 165

ZAŁĄCZNIK B: NAUCZANIE ANALIZY INTERAKCJI

DZIECKO-RODZIC. . . . . . . . . . . . . . 173

ZAGADNIENIA PODSTAWOWE ................... 173

POZIOM ROZSZERZONY . . . . . . . . . . . . . . . . . 175

ANALIZA INTERAKCJI Z PUNKTU WIDZENIA STUDENTÓW . . . . . . . . . . 176

MATERIAtY DO ZAJĘĆ ANALIZA INTERAKCJI DZIECKO-RODZIC . . . . . . . 181

PRZYKŁADOWY SYLABUS DO ZAJĘĆ FAKULTATYWNYCH ANALIZA INTERAKCJI

DZIECKO-RODZIC. . . . . . . . . . . . . . . . 181

WYBRANE POZYCJE Z LITERATURY DO ZAJĘĆ FAKULTATYWNYCH ANALIZA

INTERAKCJI DZIECKO-RODZIC . . . . . . . . . . . . . 182

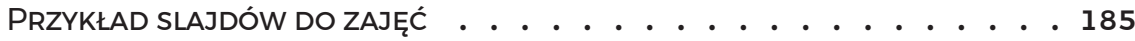

WPROWADZENIE DO ANALIZY INTERAKCJI DZIECKO-RODZIC . . . . . . . . 186

OPIS SEKWENCJI INTERAKCYJNEJ NA PODSTAWIE NAGRANIA . . . . . . 186

PROTOKÓ Z Z OBSERWACJI ZABAWY DZIECKA Z OJCEM . . . . . . . . . . 187

INSTRUKCJA DO PRZYGOTOWANIA NAGRANIA I PREZENTACJI WŁASNEJ

ANALIZY INTERAKCJI DZIECKO-RODZIC WRAZ Z KRYTERIAMI OCENY . . . . . 189

ISTOTA ZADANIA . . . . . . . . . . . . . . . . 189

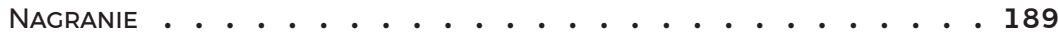

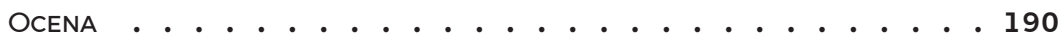

A. INFORMACJE WSTEPRE. . . . . . . . . . . . . . . . 190

B. JAKOŚĆ NAGRANIA . . . . . . . . . . . . . . . . . 191

C. ANALIZA . . . . . . . . . . . . . . . . 191 



\section{SŁOWO WSTĘPNE}

Analiza interakcji dziecko-rodzic to narzędzie stosowane w diagnozie klinicznej, a także w badaniach naukowych dotyczących rozwoju człowieka we wczesnym okresie życia. W obu kontekstach bazuje ona na założeniu, że interakcje są kształtowane przez wszystkich uczestników, w szczególności przez nieustanne wymiany i wzajemne dostosowywanie się do siebie partnerów interakcji. Dzieci od urodzenia mają wkład w przebieg interakcji, współtworząc z rodzicami złożone i dynamiczne wzorce zachowań. Takie myślenie o interakcjach zostało ugruntowane w literaturze polskiej (Babska, Shugar, 1984; Bokus, 1984; Kmita, 2005) i zagranicznej (Bornstein, Tamis-LeMonda, 2008; Sameroff, Fiese, 2000; Trevarthen, Aitken, 2001).

W myśleniu o dziecku ważne jest widzenie go jako odrębnej osoby, która ma swoje uczucia i myśli, preferencje, intencje i cele. Uczy się, poznaje świat, aktywnie kształtuje swoje relacje z innymi. Dziecko nie jest tylko odbiorcą oddziaływań innych osób i rzeczy („środowiska”), lecz również jego twórcą. Wszyscy uczestnicy interakcji są intencjonalnymi, dążącymi do osiągania osobistych celów osobami, nigdy tylko obiektami analiz. Tytuł książki umieszcza w centrum zainteresowania dziecko i jego rodziców (stąd interakcje dziecko-rodzic), jednak w istocie mam na myśli podstawowych opiekunów, czyli osoby, które pełnią rolę rodziców. W książce będę używać tych terminów zamiennie.

Celem tej pracy jest uzupełnienie istniejącej literatury o pozycję, która zbiera najważniejsze informacje na temat analizy interakcji dziecko-rodzic. Książka ma za zadanie pomóc osobom, które kształcą się lub pracują w obszarach wymagających rozumienia zachowań dzieci i ich rodziców. Mam nadzieję, że okaże się przydatna dla studentów kierunków społecznych, klinicystów i badaczy. Ze względu na rozległość i złożoność poruszanych zagadnień, wybór treści jest subiektywny, a ujęcie problemu jest tylko jednym $\mathrm{z}$ wielu możliwych podejść.

Pierwsza część książki opisuje analizę interakcji dziecko-rodzic jako narzędzie. W pierwszym rozdziale przedstawiam ogólne informacje na temat analizy interakcji w diagnozie psychologicznej i w badaniach naukowych oraz rozważania teoretyczne. W drugim rozdziale omawiam kolejne kroki analizy i interpretacji materiału obserwacyjnego, a dalej schematy oceny interakcji stosowane w badaniach naukowych. Druga część książki dotyczy 
zagadnień rozwojowych i klinicznych, których znajomość jest ważna przy stosowaniu analizy interakcji dziecko-rodzic. W rozdziale trzecim opisuję zmiany rozwojowe $\mathrm{w}$ interakcjach dziecko-rodzic w pierwszym roku życia dziecka w typowym rozwoju. W rozdziale czwartym przedstawiam wyniki badań nad interakcjami diad, w których dziecko ma zaburzenia rozwoju. Książka zawiera również załączniki: Kartę oceny interakcji do wykorzystania w kontekście klinicznym i dydaktycznym (Załącznik A) oraz propozycje skierowane do psychologów-dydaktyków, którzy chcieliby nauczać analizy interakcji dziecko-rodzic na uczelniach wyższych (Załącznik B).

Chciałabym serdecznie podziękować osobom, bez których książka ta nie mogłaby powstać: moim Mentorkom, Pani Profesor Marinie Zalewskiej i Pani Profesor Grażynie Kmicie, które uczyły mnie myślenia klinicznego, umiejętności obserwacji i nadawania znaczenia zachowaniom dzieci i rodziców. Pani Profesor Marinie Zalewskiej ogromnie dziękuję za uwagi dotyczące pierwszej wersji książki.

Dziękuję Recenzentkom, Pani Profesor Ludwice Wojciechowskiej oraz Pani Profesor Marcie Białeckiej-Pikul za wszystkie wnikliwe uwagi.

Dziękuję Pani Profesor Ewie Pisuli oraz Koleżankom i Kolegom z Katedry Psychologii Zdrowia i Rehabilitacji na Wydziale Psychologii Uniwersytetu Warszawskiego za ich ciągłe wsparcie i życzliwość.

Dziękuję Studentom, którzy współtworzyli ze mną zajęcia dotyczące analizy interakcji na Wydziale Psychologii Uniwersytetu Warszawskiego.

Szczególne wyrazy wdzięczności kieruję do wszystkich spotkanych na przestrzeni lat Dzieci i Rodziców, którzy pozwolili mi obserwować swoje interakcje. Były one dla mnie i są nadal bezcennym źródłem wiedzy i inspiracji do pracy. 


$$
\text { czEşé } 1
$$





\section{DLACZEGO ANALIZA INTERAKCJI?}

\subsection{Miejsce analizy interakcji dziecko-rodzic w diagnozie psychologicznej i w badaniach naukowych}

Interakcje społeczne, zarówno te, w których uczestniczymy, jak i te, które obserwujemy, są budulcem życia społecznego. Przybierają bardzo różne formy w świecie fizycznym i wirtualnym, mają różny przebieg, jakość i cel. Książka ta dotyczy szczególnego rodzaju interakcji - tych które są tworzone przez dziecko i rodzica. Ich wyjątkowość polega na tym, że są to pierwsze interakcje w życiu człowieka, dominują w początkowym okresie życia i stanowią kontekst rozwoju dziecka.

W tabeli 1 przedstawiłam najważniejsze pojęcia, których będę używać w tym i w kolejnych rozdziałach. Przyjmuję definicję interakcji zaproponowaną przez Kmitę (2018), ponieważ wskazuje ona, że interakcje to zachowania (poziom obserwowalny), które są wyrazem pewnej relacji (poziom intrapsychiczny, nieobserwowalny). Definicja ta uszczegóławia, że są to zachowania społeczne i mają swoje ramy czasowe. Ponadto interakcja zachodzi wtedy, kiedy partnerzy interakcyjni mają wspólne pole uwagi (uwaga uczestników jest skupiona na tym samym bodźcu, zdarzeniu czy temacie). Zatem jeżeli rodzic i dziecko budują razem wieżę z klocków, mówimy o interakcji. Czy możemy mówić o interakcji, jeżeli rodzic siedzi na krześle i czyta książkę, a dziecko siedzi na podłodze i bawi się przedmiotami? Według podanej powyżej definicji - nie. Natomiast ta konkretna sytuacja może być częścią sekwencji zdarzeń, w których interakcje przeplatają się z przerwami interakcyjnymi (okresami braku wspólnego pola uwagi).

Interakcje mają różne właściwości, które łącznie określam mianem jakości (quality) interakcji. Jest to ważny termin, ponieważ pojawia się $\mathrm{w}$ wielu badaniach, szczególnie tych nad związkami między jakością interakcji i efektami rozwoju dziecka. Jednocześnie muszę zaznaczyć, że w poszczególnych badaniach autorzy różnie jakość interakcji definiują. Na przykład często, choć nie zawsze, jednym z elementów w ocenie jakości interakcji jest synchronia interakcyjna, czyli dopasowanie zachowań partnerów w czasie. 
Tabela 1

Podstawowe pojęcia używane $w$ książce

\begin{tabular}{|c|c|c|}
\hline Termin & Definicja & $\begin{array}{c}\text { Odnośniki } \\
\text { bibliograficzne }\end{array}$ \\
\hline Interakcje & $\begin{array}{l}\text { „Są bezpośrednio obserwowalnym, } \\
\text { behawioralnym aspektem relacji } \\
\text { i obejmują sekwencję zachowań } \\
\text { ukierunkowanych społecznie, } \\
\text { w określonych ramach czasowych } \\
\text { i we wspólnym polu uwagi”. }\end{array}$ & Kmita, 2018, s. 519 \\
\hline Jakość interakcji & $\begin{array}{l}\text { Zestaw właściwości interakcji; } \\
\text { w opisie wyników badań: } \\
\text { ocena interakcji sformułowana } \\
\text { w odniesieniu do wybranych } \\
\text { kryteriów, np. poziomu } \\
\text { synchronii, koordynacji, afektu, } \\
\text { współdziałania. }\end{array}$ & $\begin{array}{l}\text { Bernier, Calkins, Bell, } \\
\text { 2016; } \\
\text { Murray i in., 2008; } \\
\text { Poehlmann, Fiese, } \\
2001\end{array}$ \\
\hline $\begin{array}{l}\text { Synchronia } \\
\text { interakcyjna }\end{array}$ & $\begin{array}{l}\text { Wzajemne, dynamiczne } \\
\text { dopasowywanie zachowań } \\
\text { partnerów interakcyjnych, które } \\
\text { zachodzi w czasie. }\end{array}$ & $\begin{array}{l}\text { Feldman, 2003; } \\
\text { Leclère i in., } 2014\end{array}$ \\
\hline Obserwacja & $\begin{array}{l}\text { Polega „na zaplanowanym } \\
\text { rejestrowaniu (...) określonych } \\
\text { zachowań”. }\end{array}$ & $\begin{array}{l}\text { Stemplewska- } \\
\text { Żakowicz, Paluchowski, } \\
2011 \text {, s. } 46\end{array}$ \\
\hline $\begin{array}{l}\text { Diagnoza } \\
\text { psychologiczna }\end{array}$ & $\begin{array}{l}\text { „Polega na nadawaniu znaczenia } \\
\text { psychologicznego zachowaniom } \\
\text { jednostki”. }\end{array}$ & $\begin{array}{l}\text { Czownicka, Zalewska, } \\
\text { 1988, s. } 34\end{array}$ \\
\hline
\end{tabular}

Analiza interakcji dziecko-rodzic ma swoje miejsce w diagnozie psychologicznej i w badaniach naukowych. W obu tych kontekstach analiza interakcji diady (lub większej liczby osób) przewyższa, moim zdaniem, analizę zachowania pojedynczych osób, np. tylko dziecka czy tylko zachowań rodzicielskich. Po pierwsze, ze współczesnego rozumienia mechanizmów rozwoju wynika konieczność uwzględnienia jego kontekstu, m.in. kontekstu relacyjnego. Piszę o tym bardziej szczegółowo w rozdziale 1.3. Po drugie, ze względu na dużą zależność dziecka od rodzica, obserwacja tych osób w interakcji jest najbardziej naturalną sytuacją obserwacyjną. Po trzecie, istnieją aspekty interakcji, takie jak synchronia interakcyjna, o których wiadomo, że mają znaczenie dla rozwoju dziecka, a można je oceniać wyłącznie analizując interakcje osób. Po czwarte, w interakcji z rodzicem dziecko pokazuje inne (często szersze) kompetencje niż podczas aktywności samodzielnej 
(zob. np. Wygotski, 2002). Wreszcie, więcej dowiadujemy się o rodzicu, kiedy obserwujemy go w interakcji z dzieckiem niż bez niego. Poznajemy wtedy wkład rodzica w tworzenie interakcji, a co za tym idzie - relacji. Patrząc na interakcje, można stwierdzić, zgodnie z podejściem systemowym, że całość stworzona przez dziecko i rodzica w interakcji jest czymś więcej niż tylko prostą sumą działań dziecka i rodzica (synteza informacji o podejściu systemowym znajduje się w pracy de Barbaro, 1999). Więcej na ten temat piszę $\mathrm{w}$ rozdziale 2.2.3.

\subsubsection{Analiza interakcji dziecko-rodzic w procesie diagnozy} psychologicznej. Przyjmuję za Czownicką i Zalewską (1988) że diagnoza to nadawanie psychologicznego znaczenia zachowaniom jednostki ${ }^{1}$. Poszłabym nawet dalej - rozumiem diagnozę psychologiczną jako próbę zrozumienia drugiego człowieka.

Chciałabym zwrócić uwagę na sposób ujmowania diagnozy psychologicznej, który proponują Stemplewska-Żakowicz i Paluchowski (2011), a mianowicie diagnoza psychologiczna jest rodzajem postępowania badawczego. Oznacza to m.in., że służy dochodzeniu do zdefiniowanego uprzednio celu, wymaga przestrzegania rygoru naukowego i obejmuje testowanie hipotez za pomocą odpowiednio dobranych narzędzi i w odniesieniu do teorii (Stemplewska-Żakowicz, Paluchowski, 2011). W rozdziale 2.1 przedstawiam schemat postępowania $\mathrm{w}$ analizie interakcji dziecko-rodzic, który polega na zbieraniu danych w celu weryfikacji hipotez i nadawaniu im znaczenia w odniesieniu do teorii. Więcej o roli teorii psychologicznej w analizie interakcji dziecko-rodzic piszę dalej, w rozdziale 1.2.

Nadmieniony rygor naukowy wymaga podstawowej umiejętności: oddzielania obserwowalnych zachowań („surowych” danych) od ich interpretacji (nadawania znaczeń). Jak pisze Brzezińska (2015, s. 149) o kształceniu osób mających analizować materiał obserwacyjny: „Podstawowym celem szkolenia powinno być więc uświadomienie jego uczestnikom konieczności oddzielania »tego, co spostrzegane« od tego »co to oznacza«, czyli różnicowanie spostrzeżeń od ich interpretacji”. Ponadto, obserwatorzy muszą wiedzieć, co obserwować, ponieważ posiadana wiedza nadaje kierunek obserwacji (Czownicka, Zalewska, 1988). Muszą być także świadomi ograniczeń metody obserwacyjnej, takich jak ryzyko popełnienia błędu wynikającego

$1 \quad$ Podsumowując rozważania definicyjne: diagnoza jest procesem, obserwacja metodą zbierania danych, a analiza interakcji narzędziem stosowanym do opracowania tych danych. 
z subiektywizmu obserwatora czy brak możliwości replikacji (Hornowska, Brzezińska, Appelt, Kaliszewska-Czeremska, 2014).

Przed zastosowaniem analizy interakcji dziecko-rodzic w procesie diagnostycznym psycholog musi sobie zadać szereg pytań, między innymi:

Jaka teoria ukierunkuje moją obserwację, analizę i nadawanie znaczeń?

Dlaczego wybrałam/em właśnie analizę interakcji dziecko-rodzic jako narzędzie diagnostyczne?

Czemu ma służyć ta analiza?

Na którym etapie procesu diagnostycznego będę ją stosować?

Jakiego rodzaju dane chcę zebrać?

Co zrobię, aby zbierane dane obserwacyjne („surowe”) były jak najbardziej obiektywne?

Jak połączę informacje uzyskane za pomocą analizy interakcji z informacjami z innych źródeł?

Odpowiedzi na te pytania pozwolą w sposób najlepszy z możliwych wykorzystać wybrane narzędzie.

\subsubsection{Analiza interakcji dziecko-rodzic w badaniach nauko-}

wych. W książce przywołuję wyniki różnych badań naukowych, w których wykorzystano analizę interakcji dziecko-rodzic, a które są jedynie małą częścią istniejącego materiału badawczego. Analiza interakcji jest użyteczna w poszukiwaniu odpowiedzi na szereg pytań badawczych dotyczących trajektorii rozwoju, identyfikacji czynników ryzyka i czynników ochronnych w rozwoju, przewidywania jego efektów, mechanizmów rozwoju typowego i nietypowego, interwencji opartych na dowodach oraz implikacji dla pracy klinicznej: diagnostyki, wspomagania i terapii.

Zasady stosowania analizy interakcji dziecko-rodzic w badaniach nie różnią się w istocie od ogólnych zasad prowadzenia badań naukowych w psychologii, które opisali Brzeziński i Zakrzewska (2011). Tutaj chcę wskazać na kilka zagadnień specyficznych dla tego narzędzia.

Po pierwsze, analiza interakcji to ogólnie rzecz biorąc narzędzie niewystandaryzowane. Choć istnieją nieliczne schematy kodowania (oceny interakcji), które są wystandaryzowane i posiadają ustalone właściwości psychometryczne, w większości badań wiedza o schemacie ogranicza się do rzetelności rozumianej jako zgodność ocen sędziów kompetentnych. Powraca tu nadmieniona wcześniej kwestia subiektywizmu obserwatora i konieczności oddzielania danych obserwacyjnych od interpretacji. 
Po drugie, analiza interakcji może obejmować różne jej aspekty i odwoływać się do różnych konstruktów i teorii psychologicznych. Może być stosowana na wiele różnych sposobów, co jest jej zaletą, ale wiąże się również z ryzykiem nieprawidłowego użycia i wyciągania nieuzasadnionych wniosków.

Po trzecie, badacz wykorzystujący analizę interakcji w zasadzie potrzebuje kompetencji klinicznych (umiejętności analizy interakcji pojedynczych diad dziecko-rodzic czy triad dziecko-rodzice w celach diagnostycznych). Wydają się one podstawą myślenia o interakcjach dziecko-rodzic i ich implikacji dla rozwoju dziecka. Nadawanie znaczenia danym badawczym zebranym w ramach analizy interakcji dziecko-rodzic ma wiele wspólnego $\mathrm{z}$ diagnozą psychologiczną. Dlatego też kompetencje osób stosujących to narzędzie muszą być szerokie.

Planując badanie z użyciem analizy interakcji, badacz musi odpowiedzieć sobie między innymi na pytania:

Jaka teoria leży u podstaw mojego badania?

Na jakie pytania badawcze odpowiem, wykorzystując dane $\mathrm{z}$ analizy interakcji? Na jakie nie?

Co zrobię, aby prowadzone badanie z użyciem analizy interakcji spełniało standardy badań naukowych?

Jakie przygotowanie muszą mieć osoby oceniające interakcje (sędziowie kompetentni)?

Jak określę trafność i rzetelność schematu oceny interakcji?

Jakie są ograniczenia użytego schematu oceny interakcji?

Czy udzielę uczestnikom badania informacji zwrotnych, odwołując się do zaobserwowanej jakości interakcji i jej potencjalnego wpływu na rozwój dziecka?

Więcej o zastosowaniach analizy interakcji w badaniach naukowych piszę $\mathrm{w}$ rozdziale 2.3 .

\subsection{Rola teorii psychologicznych $w$ analizie interakcji dziecko-rodzic}

Obserwacja interakcji dziecko-rodzic jest źródłem wielu danych. Jeszcze przed ich zebraniem diagnosta czy badacz musi wiedzieć, w jaki sposób dane te będzie analizować, ponieważ ukierunkuje to jego prace już od etapu przygotowywania sytuacji obserwacyjnej, a następnie rejestracji materiału. Po zebraniu danych konieczne będzie dokonanie wyboru, uporządkowanie 
i nadanie im znaczenia w terminach psychologicznych. W tym celu niezbędne jest odniesienie się do teorii.

Odwołania do interakcji społecznych jako kontekstu rozwoju są wyraźne w klasycznych teoriach, np. u Wygotskiego (2002). Jeśli chodzi o współczesne myślenie, Brzezińska, Appelt i Ziółkowska (2011) wskazują na znaczenie społecznej psychologii rozwoju w rozumieniu uwarunkowań zachowania człowieka i jego rozwoju. Włącza się w nie prace takich badaczy jak Schaffer, Ainsworth czy Bornstein (zob. Brzezińska i in., 2011). Szczegółowy opis tego podejścia Czytelnik znajdzie w pracy Brzezińskiej (2000). Tutaj chciałabym przywołać trzy teorie, które szczególnie uwypuklają znaczenie interakcji dziecko-rodzic w rozwoju: teorię przywiązania, model transakcyjny rozwoju i model bioekologiczny rozwoju. Podsumowanie informacji o tych podejściach zawarte jest $\mathrm{w}$ tabeli $2^{2}$.

Tabela 2

Teorie użteczne $w$ analizie interakcji dziecko-rodzic

\begin{tabular}{|c|c|c|}
\hline Ramy teoretyczne & $\begin{array}{l}\text { Aspekty kluczowe } \\
\text { dla analizy interakcji }\end{array}$ & $\begin{array}{c}\text { Odnośniki } \\
\text { bibliograficzne }\end{array}$ \\
\hline \multirow[t]{5}{*}{$\begin{array}{l}\text { Teoria przywiązania } \\
\text { (attachment } \\
\text { theory) }\end{array}$} & $\begin{array}{l}\text { Obserwacja przywiązaniowych } \\
\text { i eksploracyjnych zachowań } \\
\text { dziecka }\end{array}$ & $\begin{array}{l}\text { Ainsworth, Blehar, } \\
\text { Waters, Wall, } \\
\text { 1978/2015; }\end{array}$ \\
\hline & \multirow{2}{*}{$\begin{array}{l}\text { Fazy rozwoju przywiązania } \\
\text { i ich behawioralne wskaźniki } \\
\text { (obserwacja zmian } \\
\text { rozwojowych) }\end{array}$} & Bowlby, 1969/2007; \\
\hline & & $\begin{array}{l}\text { Polskie opracowanie } \\
\text { Lubiewska, } 2019\end{array}$ \\
\hline & $\begin{array}{l}\text { Rola wrażliwości rodzicielskiej } \\
\text { dla rozwoju przywiązania }\end{array}$ & \\
\hline & $\begin{array}{l}\text { Uwzględnienie różnic } \\
\text { indywidualnych }\end{array}$ & \\
\hline
\end{tabular}

$2 \quad$ Natomiast przegląd różnych teorii opisujących rozwój człowieka w cyklu życia, także tych w mniejszym stopniu odnoszących się do roli interakcji dziecko-rodzic, Czytelnik znajdzie w podręczniku pod redakcją Trempały (2012). 
Ciąg dalszy tabeli z poprzedniej strony.

\begin{tabular}{lll}
\hline $\begin{array}{l}\text { Model transakcyjny } \\
\text { (transactional }\end{array}$ & $\begin{array}{l}\text { Kształtowanie interakcji przez } \\
\text { dziecko i opiekuna }\end{array}$ & $\begin{array}{l}\text { Sameroff, Fiese, } \\
2000 ;\end{array}$ \\
& $\begin{array}{l}\text { Zmieniający się z wiekiem } \\
\text { dziecka wkład rodzica }\end{array}$ & $\begin{array}{l}\text { Sameroff, Mackenzie, } \\
\text { W regulację stanów dziecka }\end{array}$ \\
& $\begin{array}{l}\text { Znaczenie interakcji w obrębie } \\
\text { rodziny }\end{array}$ \\
\hline Model & Procesy proksymalne-interakcje & Bronfenbrenner, \\
bioekologiczny & zosobami i środowiskiem & Morris, 2006 \\
(bioecological & fizycznym - jako główny motor & \\
model) & rozwoju & \\
& Aby rozwijać się we wszystkich \\
& sferach rozwoju, dziecko & \\
potrzebuje uczestniczyć w coraz \\
bardziej złożonych interakcjach \\
z osobami, do których jest \\
przywiązane \\
Znaczenie wspólnej aktywności \\
dziecko-opiekun
\end{tabular}

Teoria przywiązania jest jedną z najbardziej znanych i najczęściej cytowanych teorii w odniesieniu do rozwoju w dzieciństwie, a także w rozumieniu bliskich relacji w dorosłości. Szczegółowe jej omówienie, zarówno w jeśli chodzi o badania klasyczne, jak i nowe perspektywy, można znaleźć w pracy Lubiewskiej (2019). Teoria ta obejmuje opis zmian rozwojowych i różnic indywidualnych, a także specyficznych zachowań rodzicielskich, które wpływają na jakość przywiązania (Ainsworth i in., 1978/2015). Szczególnie ważny jest tu konstrukt wrażliwości rodzicielskiej (umiejętności dostrzegania komunikatów dziecka) ${ }^{3}$ oraz uwzględnienie przywiązaniowych i eksploracyjnych zachowań dziecka, tak w sytuacji eksperymentalnej, jak i naturalnej, które mogą być przedmiotem oceny $\mathrm{w}$ analizie interakcji.

Transakcyjny model rozwoju przykłada szczególną wagę do wkładu dziecka i jego opiekuna w kształtowanie interakcji, a bardziej ogólnie do wkładu czynników indywidualnych i środowiskowych w kształtowanie trajektorii rozwoju (Sameroff, Fiese, 2000). Jest to również model, który ma służyć wyjaśnieniu wpływu czynników ryzyka i czynników ochronnych na rozwój. Obiektem rozważań jest m.in. regulacja stanów dziecka - przez

3 W oryginalnych pracach opisywano wrażliwość macierzyńską. 
innych (opiekunów) i samoregulacja oraz zmieniające się proporcje wkładu dziecka i rodzica. Początkowo stan dziecka (somatyczny, psychiczny) $\mathrm{w}$ większym stopniu zależy od rodzica, ale z czasem dziecko staje się bardziej „odpowiedzialne” za swój stan. Jednocześnie przyjmuje się, że dziecko (w tym jego zasoby i ewentualne czynniki ryzyka, np. podatność genetyczna) od urodzenia ma wpływ na kształt interakcji (Sameroff, Fiese, 2000).

Model bioekologiczny jako kontekst rozwoju wskazuje diadę matkadziecko (Bronfenbrenner, Morris, 2006). To w niej (i w środowisku fizycznym) zachodzą procesy proksymalne (proximal processes), czyli „interakcje ${ }^{4}$ między organizmem i środowiskiem, które zachodzą w czasie i są podstawowym mechanizmem kształtującym rozwój człowieka" (Bronfenbrenner, Morris, 2006, s. 795). Model ten odwołuje się również do doświadczenia (experience), czyli subiektywnej oceny środowiska przez osobę. Z kolei biologiczny aspekt tej teorii dotyczy założenia, że czynniki biologiczne i procesy ewolucyjne zawężają możliwości rozwoju człowieka (to, co człowiek może osiągnąć w rozwoju), a także wyznaczają niezbędne warunki, które pozwolą osobie osiągnąć najlepsze z możliwych efekty rozwojowe. Założenia te mają wyraźne przełożenie na sposób rozumienia interakcji dziecko-rodzic i ich roli w kształtowaniu osiągnięć rozwojowych dziecka.

Podsumowując, istnieją teorie rozwoju, które wprost odnoszą się do interakcji dziecko-rodzic, dzięki czemu są szczególnie użyteczne w procesie nadawania znaczenia psychologicznego obserwowanym zachowaniom interakcyjnym. Opisałam tu tylko wybór tych teorii, do których sama najczęściej się odwołuję.

\subsection{Interakcyjny kontekst rozwoju}

Interakcje to obserwowalne zachowania (poziom behawioralny), natomiast opisując poziom intrapsychiczny, mówimy o relacji. Tak jak wskazałam wyżej, istotą współczesnego myślenia o rozwoju człowieka jest teza, że procesy rozwojowe zachodzą w relacjach i poprzez relacje społeczne (np. Bronfenbrenner, Morris, 2006; Greenspan, Wieder, 2006; Sameroff, Fiese, 2000; Schaffer 1996/2006). Innymi słowy, człowiek staje się sobą w relacji z drugą

4 Proszę zwrócić uwagę na inne niż w pozostałej części książki użycie terminu „interakcje”. Chodzi tu o relację osoba x środowisko (społeczne, fizyczne), a nie interakcje społeczne osoba-osoba. 
osobą (Stern, 1985, 1998; Zalewska, 1998). Chodzi tu nie tylko o znaczenie relacji w rozwoju osoby (poziom psychiczny), ale także o wpływ kontekstu społecznego na rozwój struktury i funkcji mózgu (poziom biologiczny; Johnson, de Haan, 2018; Siegel, 1999). W relacji kształtują się cechy indywidualne na różnych poziomach złożoności, od poziomu komórkowego po wyższe procesy psychiczne (Phillips, Shonkoff, 2000). Wymienione powyżej prace należą do różnych podejść teoretycznych, jednak mają wspólne jedno z założeń - relacje z najbliższymi osobami są kluczowe w rozwoju człowieka.

$\mathrm{W}$ psychologii rozwoju interakcje to wymiany interpersonalne, w ramach których wszyscy uczestnicy wywierają na siebie wzajemne wpływy (Bornstein, Tamis-LeMonda, 2008). Interakcje składają się z obserwowalnych sekwencji zachowań. Pojedyncze interakcje utrwalają się, stając się wzorcami interakcji. Wzorce te są następnie internalizowane - przyjmują formę reprezentacji umysłowych. Reprezentacje te ujawniają się z kolei w interakcjach. Zatem interakcje budują relacje, a zarazem są ich wynikiem.

Dzięki rozwojowi neuronauki coraz więcej wiemy o mózgowych mechanizmach leżących u podłoża interakcji i rozwoju relacji dziecko-rodzic (Perry, Blair, Sullivan, 2017; Swain, Lorberbaum, Kose, Strathearn, 2007). Zarówno zachowania niemowlęcia, jak i zachowania opiekuńcze dorosłych mają znane korelaty mózgowe. Niemowlę od narodzin jest wyposażone w zdolność przetwarzania bodźców społecznych oraz repertuar zachowań, które umożliwiają mu angażowanie się w interakcje społeczne (Parsons, Young, Murray, Stein, Kringelbach, 2010; Trevarthen, Aitken, 2001). Rodzice natomiast są wrażliwi na różne sygnały komunikacyjne i cechy dziecka, dzięki czemu mogą dostosowywać swoje zachowania do jego potrzeb (Strathearn, 2011; Swain, Ho, 2017). Wiadomo również, że zaniedbanie i przemoc mają destrukcyjny wpływ na rozwój mózgu niemowlęcia i małego dziecka (Nemeroff, 2016; Teicher, Samson, 2016).

Wyniki wielu badań wykazały, że jakości interakcji z rodzicami jest związana z osiągnięciami rozwojowymi dziecka. Najbardziej oczywisty wydaje się związek między interakcjami i rozwojem emocjonalnym (Gadaire, Henrich, Finn-Stevenson, 2017; Kochanska, Boldt, Goffin, 2019; Rosenblum, Dayton, Muzik, 2009). Badania w tym obszarze często odwołują się do teorii przywiązania (Ainsworth, Bell, 1970; Bowlby 1969/2007), ponieważ mechanizmy wpływu jakości interakcji z opiekunami na rozwój emocjonalny wynikają wprost z jej tez. Na przykład jedna z cech zachowań rodzicielskich, wrażliwa responsywność (adekwatne i wspierające reagowanie na zachowanie dziecka), jest predyktorem kompetencji społecznych. W badaniu 
podłużnym stwierdzono, że wyższa responsywność rodzica podczas interakcji z dzieckiem w wieku 12 miesięcy wiązała się z wyższymi kompetencjami społecznymi dziecka w wieku 4,5 lat (Steelman, Assel, Swank, Smith, Landry, $2002)^{5}$. W rozdziale 2.1 przedstawiam przykład procesu nadawania znaczenia zachowaniom interakcyjnym w odniesieniu do teorii przywiązania.

Wiele uwagi poświęcono również związkom między jakością interakcji i rozwojem poznawczym (np. Gomez, Carter, Forbes, Gray, 2018; Magill-Evans, Harrison, 2001; Sethna i in., 2017; Tamis-LeMonda, Shannon, Cabrera, Lamb, 2004), szczególnie w grupach ryzyka ze względu na depresję matki (np. Ahun, Côté, 2019; Azak, Raeder, 2013; Gueron-Sela, Camerota, Willoughby, Vernon-Feagans, Cox, Family Life Project Key Investigators 2018; Murray, Fiori-Cowley, Cooper, 1996), przedwczesne narodziny dziecka (np. Forcada-Guex, Pierrehumbert, Borghini, Moessinger, Muller-Nix, 2006; Poehlmann, Fiese, 2001; Treyvaud i in., 2016) czy niski status socjoekonomiczny rodziny (np. Justice i in., 2019; Miser, Hupp, 2012; Pungello, Iruka, Dotterer, Mills-Koonce, Reznick, 2009). Jednym z mózgowych mechanizmów wyjaśniających te związki jest wpływ jakości interakcji na rozwój funkcji wykonawczych (wyższych procesów poznawczych kierujących m.in. uwagą, uczeniem się i zachowaniem), których mózgowym podłożem jest kora przedczołowa (Carlson, 2005). Bernier i in. (2016) wykazali, że wyższa jakość interakcji niemowlę w wieku 5 miesięcy-matka wiązała się z wyższą aktywnością elektryczną w obszarach czołowych kory mózgu dziecka w wieku 10 i 24 miesięcy, a także z większym wzrostem tej aktywności między 5. i 10. oraz 10. i 24. miesiącem życia. Wynik ten oznacza, że jakość interakcji ma długoterminowy wpływ na rozwój mózgu w pierwszych latach życia dziecka.

Na rolę jakości interakcji dziecko-rodzic w kształtowaniu rozwoju poznawczego dziecka wskazują również wyniki badań nad skutecznością interwencji skoncentrowanych na wspomaganiu tych interakcji. Wiadomo, że poprawa jakości interakcji może przekładać się na poprawę funkcjonowania poznawczego dziecka (Baudry, Tarabulsy, Atkinson, Pearson, St-Pierre, 2017; Obradović, Yousafzai, Finch, Rasheed, 2016).

Różne zachowania interakcyjne mogą także wpływać na przebieg zaburzeń rozwoju pojawiających się w dzieciństwie, np. autyzmu (Ginn,

$5 \quad$ Jednak nie we wszystkich badaniach stwierdzono istnienie związku między zachowaniami interakcyjnymi rodzica i kompetencjami społecznymi dziecka, np. Blandon, Calkins, Keane (2010). 
Clionsky, Eyberg, Warner-Metzger, Abner, 2017; Shire, Gulsrud, Kasari, 2016) czy zespołu nadpobudliwości psychoruchowej z deficytem uwagi (Ahmadi, Chaudhry, Olango, Molla, 2017; Chronis-Tuscano, Lewis-Morrarty, Woods, O’Brien, Mazursky-Horowitz, Thomas, 2016). Ponadto jakość interakcji może modyfikować wpływ czynników ryzyka (zwiększających prawdopodobieństwo wystąpienia zaburzeń) na rozwój dziecka. Na przykład w grupie dzieci z ryzykiem patologii rozwoju ze względu na wrodzoną wadę twarzoczaszki (Murray i in., 2008) czy wcześniactwo (Poehlmann, Fiese, 2001), wyższa jakość interakcji z matką wiąże się z lepszymi wynikami w późniejszych badaniach skalą rozwojową. Wreszcie niektóre wzorce zachowań interakcyjnych należą do mechanizmów powstawania zaburzeń zachowania (Dishion, Patterson, 2016; Moffitt, 2005; Woltering, Lishak, Elliott, Ferraro, Granic, 2015).

Najogólniej rzecz ujmując, jakość interakcji dziecko-rodzic jest związana z rozwojem samoregulacji na różnych poziomach: biologicznym, regulacji uwagi i uczenia się, emocji i zachowania (np. Feldman, 2007b, 2015; Kmita, 2013; Thomas, Martin, 1976). W konsekwencji związki te są widoczne w różnych obszarach życia na przestrzeni wielu lat. Siła oddziaływania interakcji na rozwój jest jednak największa w pierwszych latach życia, kiedy to zachodzą najbardziej intensywne procesy rozwojowe (Johnson, de Haan, 2018). Dlatego też teorie rozwoju samoregulacji są dobrym punktem odniesienia $\mathrm{w}$ analizie interakcji. W rozdziale 2.1 przedstawiony zostanie przykład procesu nadawania znaczenia zachowaniom interakcyjnym $\mathrm{w}$ terminach rozwoju samoregulacji.

Specyficzną cechą interakcji, której poświęcono wiele uwagi, jest synchronia. Ruth Feldman (2012, s. 42) definiuje ją jako „dynamiczny proces wymiany hormonalnych, fizjologicznych i behawioralnych sygnałów między rodzicem i małym dzieckiem w ramach kontaktów społecznych".

$\mathrm{W}$ odniesieniu do synchronii na poziomie behawioralnym używa się wielu zachodzących na siebie pojęć, takich jak spójna responsywność, wzajemność, dostrojenie afektywne, diadyczna regulacja afektu czy dopasowanie stanów behawioralnych (przegląd w: Harrist, Waugh, 2002). Jeśli chodzi o poziom fizjologiczny, badania najczęściej dotyczą synchronii działania przywspółczulnego i współczulnego układu nerwowego oraz układu endokrynnego, w szczególności osi podwzgórze-przysadka-nadnercza (Davis, West, Bilms, Morelen, Suveg, 2018). Najnowsze badania obejmują również synchronię mierzoną na poziomie mózgowym. W jednym z badań (Reindl, Gerloff, Scharke, Konrad, 2018) rodzice i dzieci w wieku od 5 do 9 lat grali 
w grę komputerową. W pierwszej wersji mieli za zadanie wspólnie doprowadzić do wygranej (współpraca), w drugiej każde grało osobno i miało zdobyć dla siebie zwycięstwo (rywalizacja). Ponadto dzieci wykonywały analogiczne zadanie w parze z osobą obcą. Mierzono aktywność mózgową uczestników za pomocą funkcjonalnej spektroskopii w bliskiej podczerwieni (fNIRS ${ }^{6}$ ). Okazało się, że podczas współpracy, ale nie podczas rywalizacji, aktywność mózgowa dzieci i rodziców była zsynchronizowana w pewnych obszarach kory przedczołowej. Synchronii nie stwierdzono między dzieckiem i osobą obcą ani podczas współpracy, ani podczas rywalizacji (Reindl i in., 2018).

Stopień synchronii dziecko-rodzic (w dotychczasowych badaniach zwykle dziecko-matka) wiąże się z także z różnymi trudnościami i zaburzeniami, które mogą wystąpić u matki (np. depresja) lub dziecka (np. zaburzenia rozwoju) oraz przyszłymi osiągnięciami rozwojowymi dziecka (jakość przywiązania, funkcjonowanie poznawcze, społeczne i emocjonalne), bardzo pomocny przegląd Czytelnik znajdzie w pracy Leclère i in. (2014). Niedawna metaanaliza potwierdziła, że cały szereg wyników badań wykazał pozytywny związek między synchronią dziecko-rodzic i samoregulacją dziecka (Davis, Bilms, Suveg, 2017). Poziom synchronii jest zatem wartościową, choć wymagająca szczegółowego zdefiniowania i zoperacjonalizowania, miarą funkcjonowania diady.

Interakcje dziecko-rodzic są procesami złożonymi, dynamicznymi i uwarunkowanymi szerokim kontekstem społecznym i niespołecznym. W związku z tym badanie interakcji jest praco- i czasochłonne, a wynik danej analizy obejmuje tylko wycinek rzeczywistości dotyczący pewnych aspektów interakcji i funkcjonowania psychicznego uczestników. Jednak, pomimo trudności koncepcyjnych i metodologicznych, które wynikają z takiego podejścia, analiza zachowania osób w interakcjach wydaje się jednym z najlepszych narzędzi badania mechanizmów funkcjonowania psychicznego człowieka i ich rozwoju.

6 Jest to metoda obrazowania aktywności mózgu wykorzystująca falę świetlną. Dokonuje się pomiaru poziomu hemoglobiny utlenowanej w naczyniach mózgowych, podczas gdy osoba wykonuje zadania (Lloyd-Fox, Blasi, Elwell, 2010). 


\section{ANALIZA INTERAKCJI JAKO NARZĘDZIE DIAGNOSTYCZNE I BADAWCZE}

\subsection{Analiza interakcji krok po kroku}

Analiza interakcji to narzędzie służące do opracowywania materiału obserwacyjnego. Jej istotą jest nadawanie znaczenia zachowaniom osób, aby zrozumieć mechanizmy funkcjonowania ich osobowości (Czownicka, Zalewska, 1988). Analizując interakcje, uwzględniamy relacyjny kontekst zachowania wszystkich uczestników. Przyglądamy się złożonym sekwencjom zachowań (wymianom behawioralnym) współtworzonym przez osoby i stawiamy hipotezy odnośnie przyczyn, celu i skutków tych zachowań dla rozwoju poszczególnych osób i ich relacji. Psychiczne źródło obserwowanych zachowań zarazem kształtuje interakcje, jak i jest ich produktem.

Interakcje warto analizować według pewnego planu, który pozwoli rzetelnie i dokładnie opracować materiał obserwacyjny, od poziomu zachowań do syntezy danych i ich interpretacji. Dobrze jest najpierw dokonać surowego opisu zachowania osób. Następnie warto opisać własne uczucia i myśli, które pojawiły się podczas obserwacji. W kolejnym kroku można opisać interakcje na poziomie ogólnym, aby następnie wybrać poszczególne zachowania lub ich sekwencje i dokładniej się im przyjrzeć. Zachowaniom tym lub sekwencjom próbujemy nadać znaczenie w terminach wybranej teorii. Kolejny etap to integracja zgromadzonych informacji i wstępna ich interpretacja (sformułowanie hipotez interpretacyjnych). Interpretacja ta powinna uwzględniać wątpliwości i ograniczenia wynikające z warunków, czasu trwania i przebiegu obserwacji oraz dyspozycji osób badanych. W końcowej części warto sformułować pytania na przyszłość oraz w idealnych warunkach, zaplanować następną obserwację. Dzięki kolejnym obserwacjom możliwe będzie powtarzanie wcześniej opisanych kroków, co odpowiada dokonywaniu kolejnych pomiarów w badaniach naukowych. W takiej sytuacji można 
pozyskać dane, których wcześniej nie udało się zebrać oraz weryfikować wcześniej postawione hipotezy interpretacyjne. Wreszcie, po uwzględnieniu wszystkich informacji, można podjąć się sformułowania ostatecznej interpretacji. Jeżeli możliwa jest tylko jedna obserwacja, interpretacja będzie trudniejsza, obciążona większym ryzykiem błędu i będzie zawierała wiele pytań i niepewności.

Nieodłącznym elementem analizy interakcji dziecko-rodzic są ramy teoretyczne, które przyjmuje obserwator. Wybrana teoria - jej założenia, terminologia i implikacje praktyczne - kształtuje wszystkie kroki analizy. W najmniejszym stopniu dotyczy to surowego opisu, bo powinien on bowiem być jak najbardziej neutralny. Natomiast kolejne etapy analizy i jej wynik są zawsze mocno osadzone w teorii, do której odwołuje się obserwator. Wielość możliwych interpretacji tych samych zachowań dziecka w zależności od przyjętej perspektywy teoretycznej unaoczniają Czownicka i Zalewska (1988). Autorki przedstawiają aż 10 różnych interpretacji jednej krótkiej sekwencji zachowań dziecka.

Co ważne, pojęcia opisywane przez wybraną teorię muszą przekładać się na obserwowalne zachowania (w procesie zwanym operacjonalizacją). $\mathrm{Na}$ przykład wrażliwość rodzicielska wyraża się w określonych zachowaniach, dobrze opisanych w literaturze. Dzięki temu, jeżeli odpowiednio zaaranżujemy sytuację obserwacyjną, pozwalając rodzicowi swobodnie decydować o własnym zachowaniu, będziemy mieli szansę zaobserwować konkretne zachowania (wskaźniki), na podstawie których określimy poziom wrażliwości rodzica.

2.1.1. Surowy opis. Surowy opis interakcji powinien zawierać jedynie to, co widzi obserwator. Oczywiście nie jest możliwe przygotowanie w pełni neutralnego opisu zachowania, pozbawionego wpływu obserwatora. Podczas obserwacji, pomimo wszelkich wysiłków, diagnosta podlega wpływowi zniekształceń poznawczych i emocjonalnych (zob. prace dotyczące diagnozy psychologicznej: Stemplewska-Żakowicz, 2009; Stemplewska-Żakowicz, Paluchowski, 2011). Ponadto doświadczony specjalista jest w stanie dostrzec znacznie więcej szczegółów niż osoba początkująca. Niemniej jednak, w surowym opisie należy dążyć do jak najwierniejszego oddania przebiegu interakcji, bez uwzględniania subiektywnych odczuć, opinii ani prób interpretacji. Objętość i szczegółowość opisu zależą od celów analiz. 
Przykład:

Fragment surowego opisu zachowania diady dziecko-matka

Osobami obserwowanymi sa Hania (18 miesięcy) i jej mama (32 lata). Obserwacja ma miejsce na placu zabaw. Oprócz Hani i jej mamy obecny jest obserwator oraz troje innych malych dzieci i trzy osoby dorosłe. Plac zabaw ma w przybliżeniu wielkość klasy szkolnej i jest odgrodzony płotkiem. Wewnątrz znajduja się zjeżdżalnia, domek, huśtawka, piaskownica, zabawki rozrzucone na ziemi, a przy płotku wózki dziecięce. Hania i jej mama znajduja się wewnątrz placu, a obserwator po drugiej stronie płotka.

Hania stoi przodem do piaskownicy, spojrzenie ma skierowane w jej stronę, wyraz twarzy neutralny. Mama podchodzi do Hani, pyta „Chcesz piciu?” i podaje jej bidon. Hania odwraca się plecami i odchodzi w kierunku zjeżdżalni. Podchodzi do drabinki, która pozwala na nią wejść i stawia prawą nogę na pierwszym szczeblu, ręce opiera na wyższych szczeblach, patrzy przed siebie. Mama podchodzi do niej, chwilę stoi z boku, po czym mówi „Daj rączkę”. Hania puszcza drabinkę i prawą rękę podaje mamie, patrząc przed siebie, a mama bierze ją za rękę i podtrzymując w okolicy talii podnosi ją na górę zjeżdżalni, przy czym Hania podpiera się nogami o szczebelki. Postawiona na górze zjeżdżalni, Hania spogląda na mamę, uśmiecha się. Mama uśmiecha się i mówi „No, mama raczej tam nie wejdzie”. Hania odwraca głowę przodem w kierunku zjazdu, siada, odpycha się rękami i nogami i zjeżdża. Stojąc na dole zjeżdżalni, uśmiecha się szeroko, patrząc przed siebie. Mama, która przez cały czas patrzyła na Hanię, stojąc przy drabince, zaczyna klaskać, szeroko się uśmiecha.

2.1.2. Opis własnych odczuć. Świadomość i rozumienie własnych reakcji na zachowania innych osób są istotnymi elementami analizy materiału obserwacyjnego. Własne doświadczenia relacyjne obserwatora mogą zniekształcać jego postrzeganie zachowań i proces ich interpretacji. Dlatego też obserwator musi uważnie przyglądać się swoim uczuciom i myślom, a jeżeli jest uczestnikiem interakcji, także zachowaniom. Ważne, aby mieć świadomość, w jaki sposób przeszłe, bieżące oraz wyobrażane przyszłe doświadczenia mogą kształtować nasze postrzeganie zachowania innych osób oraz sposób, w jaki nadajemy znaczenie tym zachowaniom. Zróżnicowanie przeżyć związanych z obserwacją interakcji dziecko-rodzic uwidacznia się, 
kiedy analiza materiału odbywa się w grupie, na przykład podczas zajęć dydaktycznych. Nierzadko te same zachowania wywołują skrajnie różne emocje i refleksje.

Pierwsze pytanie, które warto sobie zadać po obejrzeniu interakcji to: jak się czułam/em, patrząc na tę interakcję? Czy było to dla mnie przyjemne doświadczenie, czy trudne? Czy coś mnie zirytowało, zezłościło, zasmuciło? Czy byłam/em cały czas zaciekawiona/y, czy też szybko się znudziłam/em? Czy coś mnie zdziwiło lub zaskoczyło? Czy z łatwością współodczuwałam/ em z obserwowanymi osobami? Czy coś mnie zaniepokoiło lub przestraszyło? Te informacje są ważnymi wskazówkami w dalszej analizie i interpretacji, a także mogą umożliwić dostrzeżenie, w jaki sposób nastrój, dyspozycja, cechy, doświadczenia czy oczekiwania obserwatora mogą zniekształcać jego postrzeganie danej interakcji.

2.1.3. Opis ogólny. W kolejnym kroku dobrze jest opisać ogólne cechy interakcji. W szczególności warto ocenić ton emocjonalny interakcji i dominujący nastrój (radość, smutek, złość, napięcie itd.), a także nasilenie obserwowanych emocji (słabe, umiarkowane, intensywne). Warto zaobserwować, czy ton emocjonalny zmienia się w toku interakcji, jaka jest sekwencja nastrojów i jakie wydarzenia poprzedzają zmiany. Następnie próbujemy określić styl interakcyjny poszczególnych osób (zaangażowany, wycofany, aktywny, bierny, uległy, intruzywny, kontrolujący, współpracujący, ugodowy, itd.) i zależności między stylami rodzica i dziecka. Zastanawiamy się, czy przebieg interakcji jest naturalny, swobodny, czy też sprawia wrażenie wymuszonego.

Ważne jest opisanie struktury interakcji, która obejmuje naprzemienność i długość sekwencji zachowań oraz wkład poszczególnych uczestników w te sekwencje. Oceniamy symetrię interakcji, czyli proporcjonalny wkład osób. Jeden z uczestników może dominować czy nadawać kształt interakcji (interakcja asymetryczna). Może też istnieć pewna równowaga wkładów (interakcja symetryczna). Jest to ważne ze względu na naturalne zmiany rozwojowe: podczas gdy w interakcjach $\mathrm{z}$ młodszymi dziećmi oczywista jest asymetria: dominujący rodzic - zależne dziecko, z wiekiem zdolność dziecka do wpływania na kształt interakcji rośnie, można zatem oczekiwać zmian w kierunku symetrii. Oczywiście, w toku jednej interakcji mogą mieć miejsce okresy asymetrii i symetrii. Warto przyjrzeć się, z jakimi zachowaniami, emocjami czy formami aktywności wiążą się te epizody; co prowadzi do przejścia od asymetrii do symetrii i vice versa? W interakcjach triadycznych 
możemy zaobserwować, czy wszystkie osoby biorą aktywny udział w interakcji, czy ktoś jest wycofany lub wykluczany (kto? w jaki sposób?).

Kolejnymi cechami interakcji są tempo i jego zmiany oraz stopień organizacji. Czy wydarzenia toczą się szybko, czy raczej wolno? Czy interakcje przebiegają płynnie? Czy następują nagłe, gwałtowne zmiany? Czy interakcja wydaje się chaotyczna, czy uporządkowana, a następowanie po sobie zachowań wydaje się logiczne?

Powstały w ten sposób ogólny opis jest tłem dla dalszej, bardziej szczegółowej analizy wybranych zachowań.

2.1.4. Opis wybranych zachowań lub ich sekwencji. Opis wybranych zachowań jest podobny do surowego opisu interakcji pod tym względem, że powinien być pozbawiony ocen i interpretacji obserwatora. Jest on jednak bardziej szczegółowy. Jego celem jest zwrócenie uwagi na poszczególne epizody interakcyjne, istotne zwłaszcza ze względu na cel analiz i z punktu widzenia wybranych ram teoretycznych. Umożliwia on wydobycie części składowych budujących cały materiał obserwacyjny. Poszczególne sekwencje zachowań warto opisywać niezależnie od siebie. W ten sposób, każda z nich jest odrębną próbką zachowania. Szczegółowa analiza zachowań pozwala dostrzec kompetencje i właściwości zachowania osób, niezbędne do oceny ich wkładu w przebieg interakcji. 
Przykład:

Opis sekwencji zachowań diady dziecko-ojciec

Chłopiec w wieku 9 miesięcy i jego tata. Oboje siedzq na podłodze obok siebie tak, że ich twarze znajduja się pod kątem około $45^{\circ}$ względem siebie.

1. Chłopiec siedzi z podparciem i wokalizuje, patrzy przed siebie. Pochyla się w przód i wyciąga rękę w kierunku piłeczki, która leży przy jego nodze. Końcami palców dotyka piłeczki. Patrzy w dół, w kierunku piłeczki, na krótko przenosi wzrok w stronę taty, wciąż będąc pochylonym (widzi prawdopodobnie nogi taty). Przenosi wzrok z powrotem na piłkę. W tym czasie tata patrzy na książeczkę, którą trzyma w rękach. Przekłada strony, wzrok ma skierowany na książeczkę.

2. Chłopiec, wciąż pochylony, wokalizuje. Końcami palców dotyka piłeczki. Prostuje się, patrzy przed siebie. Przenosi wzrok na tatę. W tym czasie tata patrzy na książeczkę.

3. Chłopiec wokalizuje, przenosi wzrok na piłeczkę, pochyla się w jej kierunku. Końcami palców dotyka piłeczki, patrzy na nią.

4. Tata przenosi wzrok w stronę dziecka. Wyciąga rękę w kierunku piłeczki (w polu widzenia ma prawdopodobnie dziecko i piłeczkę).

5. Chłopiec prostuje się. Przenosi wzrok na tatę. Rozkłada ręce na bok.

2.1.5. Nadawanie znaczenia wybranym zachowaniom. Istnieją pewne warunki, których spełnienie pozwala rzetelnie nadawać znaczenie zachowaniom uczestników interakcji. W tym kontekście rzetelność oznacza, że formułowane wnioski są uzasadnione merytorycznie, a proces dochodzenia do nich można dokładnie prześledzić i odtworzyć. Rzetelne podejście do analizy interakcji chroni obserwatora i uczestników przed możliwymi konsekwencjami wysnuwania nieuprawnionych wniosków, dokonywania niemerytorycznych ocen i wychodzenia poza określony w kontrakcie lub celu badania naukowego zakres analiz. 
Po pierwsze, cały proces obserwacji i analizy musi być spójny z wybraną teorią. Na przykład, aby wnioskować o wzorcu przywiązania dziecko-opiekun, niezbędna jest obserwacja zachowania obojga w kilku określonych sytuacjach. Między innymi należy przyjrzeć się reakcji dziecka na rozłąkę i na powrót rodzica po okresie rozłąki. Jeżeli warunki nie pozwalają na obserwację takich zachowań, możliwość wnioskowania o jakości przywiązania jest ograniczona. Po drugie, zaaranżowana sytuacja obserwacyjna musi umożliwiać uczestnikom w miarę swobodną ekspresję behawioralną. Każde ograniczenie swobody uczestników (np. prośba, aby pozostawali w określonym miejscu, czy używali danych przedmiotów) należy uwzględnić w procesie nadawania znaczenia ich zachowaniu. Jeżeli poprosimy rodzica, aby podczas obserwacji niemowlę pozostawało $\mathrm{w}$ foteliku, zakres zachowań samoregulacyjnych dostępnych dla obojga będzie zawężony (np. niemowlę nie będzie mogło się odwrócić całym ciałem, czy oddalić, rodzic nie będzie mógł go wziąć go na ręce). Po trzecie, czas obserwacji musi być na tyle długi, aby obserwator mógł być świadkiem wielu zachowań.

Po wybraniu zachowań do interpretacji szukamy dla nich nazwy w terminologii właściwej dla danego podejścia teoretycznego. Następnie, odwołując się do posiadanej wiedzy, rozważamy możliwe interpretacje każdego z zachowań. 
Przykład:

Interpretacja zachowania $w$ terminach teorii przywiazania

Dwunastomiesięczne dziecko, jego rodzic i osoba obca znajduja się w nowym dla dziecka pomieszczeniu.

1. Zachowanie: dziecko raczkuje w kierunku rodzica.

2. Nazwa zachowania w terminach teorii przywiązania: poszukiwanie bliskości.

3. Hipotezy interpretacyjne: dziecko odczuwa lęk przed osobą obcą i reguluje emocje, poszukując bliskości z rodzicem; dziecko posiada reprezentacje rodzica jako bezpiecznej przystani.

4. Fragment wstępnej interpretacji: zachowanie jest przejawem ufności przywiązaniowej dziecka.

5. Plan dalszych obserwacji: zachowania eksploracyjne w obecności rodzica i osoby obcej, interakcje z osobą obcą, reakcja dziecka, kiedy kieruje się ona do wyjścia.

2.1.6. Integracja informacji. Po opisaniu co najmniej kilku określonych zachowań i ich sekwencji, przystępujemy do syntezy zebranych informacji dotyczących własnych odczuć, ogólnej oceny interakcji, szczegółowej analizy sekwencji zachowań oraz różnych aspektów zachowania dziecka, rodzica i diady. Uwzględniamy również inne posiadane informacje, np. stan zdrowia dziecka i rodzica, ważne wydarzenia w ich życiu, sytuację rodzinną i społeczną. Po połączeniu wszystkich informacji formułujemy coraz bardziej szczegółowe hipotezy interpretacyjne. Do stworzenia ostatecznej interpretacji prowadzi proces formułowania i weryfikowania kolejnych hipotez interpretacyjnych. Tak jak w badaniach naukowych, hipoteza jest tylko rodzajem przypuszczenia i nie należy się do niej przywiązywać (chociaż mamy taką tendencję!). Poszukiwanie faktów zaprzeczających wstępnym hipotezom jest tak samo ważne, jak szukanie argumentów ją potwierdzających. 
Następnie zastanawiamy się, jakich informacji brakuje do przygotowania całościowej interpretacji. W idealnych warunkach - przeprowadzamy kolejne obserwacje i dokonujemy ponownych analiz. Niezwykle trudno jest zrozumieć zachowanie osób na podstawie jednej obserwacji. W diagnozie klinicznej dziecka i rodziny niezbędnych jest co najmniej kilka spotkań (obejmujących również wywiad). Ponadto warto korzystać z możliwości zaobserwowania interakcji w różnych kontekstach. Obserwacje w gabinecie można na przykład uzupełnić nagraniami zarejestrowanymi w domu lub na placu zabaw. Dzięki analizie danych obserwacyjnych zebranych podczas kilku kolejnych spotkań w gabinecie psychologa, można również ocenić zmiany następujące ze spotkania na spotkanie. Jest to ważne, ponieważ trakcie procesu poznawania się zmienia się kontekst relacyjny interakcji. Mianowicie, klinicysta staje się częścią obserwowanego systemu. Ponadto otoczenie jest coraz bardziej znajome dla dziecka i rodziców, a uczestnicy mogą podczas kolejnych spotkań odwoływać się do doświadczeń z poprzednich wizyt. Jednocześnie pod względem formalnym sytuacja pozostaje podobna, tzn. możliwości (osoby, wyposażenie gabinetu) i ograniczenia fizyczne są w zasadzie takie same.

Jak wyjaśniono wcześniej, umieszczenie osób w określonej sytuacji definiuje zakres możliwych zachowań. Dlatego możliwość stawiania hipotez, a co za tym idzie interpretacja zachowań rodziców i dziecka wyłącznie na podstawie obserwacji przeprowadzonych w gabinecie (lub laboratorium), jest ograniczona.

Zdarza się, że obserwując interakcje dziecko-rodzic, dostrzegamy zachowania, które wydają się sprzeczne. Po części wynika to ze złożoności ludzkiej psychiki. Jest to również argument za zbieraniem wielu danych obserwacyjnych przed przystąpieniem do ich interpretacji. Należy również pamiętać, że niespójność, ambiwalencja i uderzające sprzeczności w zachowaniu osób są ważnymi wskazówkami diagnostycznymi. Sprzeczne zachowania różnego rodzaju są bowiem właściwe m.in. dla lękowo-ambiwalentnego i zdezorganizowanego wzorca przywiązania. Klinicyści mówią również o podwójnym wiązaniu, polegającym na kierowaniu do drugiej osoby sprzecznych komunikatów, na które odbiorca nie może zareagować w sposób dla siebie korzystny (Bateson, 1972/2001). Ponadto obserwator może zauważyć, że ma szczególne trudności ze zrozumieniem interakcji w danej rodzinie. Należy wtedy zadać sobie pytanie, co może utrudniać zrozumienie tych właśnie interakcji. Czy może wynika to z sytuacji obserwacyjnej? A może materiał obserwacyjny wzbudza w obserwatorze bardzo silne emocje? W takiej 
sytuacji potrzebna może być pomoc innego specjalisty. Chaotyczne, pełne sprzecznych zachowań, trudne pod względem emocjonalnym interakcje wymagają wielokrotnych obserwacji. Powinniśmy się również zatrzymać, jeżeli interpretacja materiału obserwacyjnego przebiega niezwykle łatwo. Interakcje dziecko-rodzic lub rodzice, nawet te „dobre” jakościowo, uporządkowane i płynne, są bardzo złożonymi procesami, zatem należy wystrzegać się pochopnych, powierzchownych interpretacji.

2.1.7. Ostateczna interpretacja. Po etapie testowania hipotez przychodzi czas na ostateczną interpretację. Podsumowujemy argumenty za i przeciw różnym hipotezom interpretacyjnym i uzyskany wynik analizy formułujemy, używając terminologii właściwej dla wybranej teorii.

Analiza interakcji jest rodzajem wnioskowania naukowego. Dlatego też pracujemy zgodnie z przyjętym planem. Wychodzimy zawsze od zaobserwowanych zachowań i traktujemy je jako wskaźniki pewnych konceptów psychologicznych. Powstrzymujemy się od osądzania. Oczywiście każdy rodzaj diagnozy klinicznej ma charakter oceny, jej celem nie jest jednak wartościowanie. O rzetelnej analizie możemy mówić wyłącznie, kiedy odwołuje się ona do uznanej, sprawdzonej empirycznie teorii.

Przedstawiona tu analiza interakcji jest wartościowym, lecz niełatwym $\mathrm{w}$ stosowaniu narzędziem. Wynika to z konieczności opisywania zachowania uczestników w całej jego złożoności, zachowanie natomiast uwarunkowane jest wieloma czynnikami. Analizujemy różne wymiary zachowania, ponieważ wnioskowanie w odniesieniu do konstruktów teoretycznych wymaga wielu wskaźników.

Forma zapisu wyników analizy interakcji zależy od jej celu. Klinicysta, który prowadzi dokumentację swojej pracy, może opracować raport. Powinien on zawierać opis warunków obserwacji i aktywności podejmowanych przez uczestników. Zgodnie z zaproponowanym tu schematem analizy, należy wyodrębnić części poświęcone opisowi „faktów” subiektywnym odczuciom i interpretacjom. Dla każdej interpretacji warto podać przykłady zachowań, które ją uzasadniają. Należy zawsze udzielić ustnej informacji zwrotnej uczestnikom interakcji, zgodnie z ogólnymi zasadami obowiązującymi psychologów pracujących klinicznie.

Wreszcie, nadając znaczenia zachowaniom innych osób, warto kierować się zasadą ograniczonego zaufania do siebie. Ostateczna interpretacja nie oznacza bowiem interpretacji pełnej i niepodważalnej. Zawsze istnieje powinien poziom niepewności, wynikający z niedoskonałości narzędzia 
obserwacji, którym w przypadku analizy interakcji jest człowiek. Ponadto należy mieć świadomość, że rozwój we wczesnym dzieciństwie jest niezwykle dynamiczny, dlatego prowadzone analizy wymagają powtórnych obserwacji, a płynące z nich wnioski - modyfikacji. Powyższe ograniczenia metodologiczne powinny mieć odzwierciedlenie w opiniach i informacjach zwrotnych przygotowywanych przez klinicystę oraz raportach opracowywanych przez badaczy.

W dalszej części rozdziału przedstawiam informacje, które ułatwią szczegółową analizę interakcji na poziomie osób i diady.

\subsection{Uczestnicy interakcji}

2.2.1. Poziom osoby: dziecko. Dostępnych jest wiele podręczników, rozdziałów i artykułów dotyczących rozwoju dziecka. Dlatego w tej książce nie będę przedstawiać informacji, które Czytelnik znajdzie w innych opracowaniach ${ }^{7}$. Najważniejsze informacje dotyczące obserwacji dziecka i rodziców lub opiekunów zawarte są w artykułach Czownickiej i Zalewskiej (1988; w tomie tym na stronach 80-82 znajdują się cenne Kategorie analizy materiału obserwacyjnego) i Brzezińskiej (2015) oraz w rozdziale 2. książki Hornowskiej i in. (2014).

Chcę tu zwrócić uwagę na najważniejsze sfery rozwoju i osiągnięć rozwojowych, które zawsze wymagają obserwacji, kiedy przystępujemy do analizy interakcji dziecko-rodzic. Można je przyporządkować do kilku grup: rozwój ruchowy, poznawczy, emocjonalny, społeczny i językowy. Podział taki ma oczywiście sztuczny charakter i służy jedynie uporządkowaniu informacji. W rzeczywistości kompetencje we wszystkich obszarach przenikają się i łączą, tworząc złożony obraz funkcjonowania dziecka. Aby móc rzetelnie ocenić poziom rozwoju dziecka, należy prowadzić obserwację w warunkach dla niego sprzyjających, w porze dnia, kiedy zwykle jest aktywne.

1. Rozwój ruchowy

Motoryka duża (ruchy całego ciała)

Motoryka mała (precyzyjne ruchy części ciała, np. palców rąk)

Napięcie mięśniowe i siła mięśni

Koordynacja ruchowa

Poziom aktywności i energii

7 Polecam podręczniki autorstwa Schaffera (1996/2006) oraz Schaffera i Kipp (2015). 
2. Rozwój poznawczy

Percepcja za pomocą różnych zmysłów

Uwaga (pojemność, wycofywanie, przenoszenie, utrzymywanie, rozpraszalność)

Uczenie się i pamięć

Teoria umysłu

Rozumienie pojęć, symboli, zależności i procesów

Planowanie i rozwiązywanie problemów

3. Rozwój emocjonalny

Wyrażanie emocji

Rozpoznawanie emocji i reagowanie na emocje innych osób

Regulacja emocji, odraczanie gratyfikacji, reakcja na frustrację

Rozumienie emocji

Empatia (współodczuwanie, empatia emocjonalna, empatia poznawcza)

4. Rozwój społeczny

Funkcjonowanie w relacjach

Funkcjonowanie w grupie

Współdziałanie i rywalizacja

Rozumienie zasad społecznych i stosunek do nich

Rozwój moralny

5. Komunikacja

Niewerbalna

Werbalna (mowa bierna i czynna)

Łączenie komunikatów niewerbalnych z werbalnymi

6. Rozwój tożsamości

Poczucie siebie, pojęcie Ja, tożsamość

7. Temperament i reagowanie na bodźce zmysłowe

8. Zdolności

Umiejętności związane z codziennym funkcjonowaniem

Ponadprzeciętne umiejętności

9. Trudności rozwojowe

Nieprawidłowości w zachowaniu

Istnieją pewne szczegółowe pytania, które warto sobie zadać, analizując interakcje dziecka $\mathrm{z}$ bliskimi i obcymi osobami. W jaki sposób dziecko inicjuje, podtrzymuje i przerywa interakcje? Jak odpowiada na inicjatywy interakcyjne (zachowania drugiej osoby mające na celu nawiązanie lub 
podtrzymanie interakcji)? W jaki sposób wyraża akceptację i odmowę? Jak wyznacza fizyczny i psychiczny dystans między sobą i innymi? Czy próbuje skracać dystans wyznaczony przez inne osoby, a jeżeli tak, to w jaki sposób? Czy podąża za uwagą i linią aktywności drugiej osoby? Czy podejmuje próby kierowania jej zachowaniem?

Ponieważ interakcje wymagają od uczestników ciągłego interpretowania zachowań drugiej osoby, należy zwrócić uwagę na to, czy obserwator jest w stanie zrozumieć komunikaty dziecka. Na dalszych etapach analizy pojawi się pytanie, czy komunikaty te rozumie rodzic.

Warto obserwować interakcje dziecko-dorosły w różnych kontekstach. Dzięki temu możliwe jest zaobserwowanie, jak dziecko zachowuje się w znanym, a jak w obcym otoczeniu. Jak reaguje na nowość (nowopoznane osoby, miejsca, przedmioty)? Jakie emocje towarzyszą jego zetknięciu z nowością? ${ }^{8}$ Jak poznaje nowe elementy środowiska? Co robi, kiedy nie znajduje w otoczeniu osób lub przedmiotów, które wzbudzają w nim ciekawość? Jak reaguje na monotonię, niezmienność, rutynę?

Podstawowymi formami aktywności dziecka są zabawa i eksploracja. Dlatego często analizuje się interakcje dziecko-rodzic lub rodzice w sytuacji umożliwiającej im bawienie się i poznawanie otoczenia. Obserwując zabawę dziecka z opiekunem, należy zwrócić uwagę na to, jakiego rodzaju aktywności (formy zabawy) wybiera każde z nich. Jak bardzo zróżnicowana jest zabawa dziecka? Czy jest adekwatna do wieku? W jakim stopniu polegają na wykorzystaniu przedmiotów, a w jakim na udziale innych osób? Czy aktywność zabawowa jest spontaniczna, czy sztywna? Chaotyczna, czy uporządkowana? Czy zmienia się w czasie, a także pod wpływem aktywności dorosłych? Jakie emocje jej towarzyszą? Czy emocje te są adresowane do innych osób?

W obserwacji dziecka proponuję przyjmować zasadę „od ogółu do szczegółu”, to znaczy najpierw opisywać szerokie kategorie i najważniejsze kompetencje, a następnie bardziej szczegółowe obszary i podkategorie zachowań.

Ponieważ zagadnienia związane z obserwacją dziecka są bardzo rozległe, warto ułatwić sobie zbieranie informacji, odwołując się do wybranej koncepcji czy modelu rozwoju. Pomoże to nie tylko uporządkować proces zbierania danych, ale także, na dalszym etapie, nadać znaczenie zachowaniom.

8 Reakcja na nowość jest jednym z przejawów temperamentu. O temperamencie małych dzieci Czytelnik może się dowiedzieć z prac Mary Rothbart (np. Gartstein, Rothbart, 2003) czy Wojciecha Dragana (2014). 
Użyteczne mogą być również klasyfikacje diagnostyczne, np. Klasyfikacja diagnostyczna DC: 0-3R (polska wersja pod red. Kmity [2007]) oraz nowsza DC: 0-5 (ZERO TO THREE, 2016), które zawierają opis obszarów podlegających ocenie w diagnozie dziecka. Polecam także zapoznanie się z Kategoriami analizy materiatu obserwacyjnego zaproponowanymi przez klinicystki Czownicką i Zalewską (1988).

Ważne jest, aby pamiętać, że zadaniem obserwatora jest nie tylko odnoszenie widocznych zachowań do norm rozwojowych, czy ocena harmonijności rozwoju. Dla psychologa szczególnie ważne jest pytanie, co dla dziecka wynika z posiadania danej umiejętności (lub z opanowania jej w ograniczonym czy niedostatecznym stopniu)? W jaki sposób umiejętność ta wpływa na jego możliwości poznawania siebie i otaczającego go świata, relacje z innymi osobami oraz ogólne funkcjonowanie w różnych sytuacjach? Pytania specyficzne dla analizy interakcji dotyczą tego, w jaki sposób dziecko, mając określone kompetencje, może kształtować interakcje. Czy w interakcjach z daną osobą wykorzystuje wszystkie swoje umiejętności? W jaki sposób niedobór pewnych umiejętności (czy to wynikający z typowej dla wieku niedojrzałości, czy też z powodu nieprawidłowości w rozwoju) wpływa na przebieg i jakość tych interakcji?

Analiza interakcji dziecko-rodzic może mieć szczegółowy cel. Na przykład może być elementem diagnozy dziecka pod kątem zaburzeń ze spektrum autyzmu (autism spectrum disorders, ASD). W takim wypadku obserwator będzie zwracał szczególną uwagę na zachowania interakcyjne, które wiążą się z kryteriami diagnostycznymi, np. inicjowanie interakcji i reagowanie na inicjatywy drugiej osoby, podążanie za wzrokiem, uwspólnianie uwagi, wskazywanie, łączenie komunikatów niewerbalnych z werbalnymi, sztywność versus elastyczność zachowania, zróżnicowanie aktywności, zaangażowanie we wspólne działanie itd. (zob. kryteria diagnostyczne w ICD11; World Health Organization [WHO], 2018). Ze względu na to, że wyżej wymienione zachowania mają w ASD specyficzny obraz, obserwując je, diagnosta będzie mógł odróżnić objawy ASD od np. opóźnienia rozwoju (a u starszych dzieci niepełnosprawności intelektualnej) czy opóźnienia rozwoju mowy. Niezwykle ważne będzie porównanie jakości interakcji dziecko-osoba bliska z interakcjami dziecko-klinicysta lub dziecko-nauczyciel, ponieważ jednym z kryteriów diagnostycznych ASD jest utrzymywanie się objawów $\mathrm{w}$ różnych sytuacjach, $\mathrm{w}$ interakcjach $\mathrm{z}$ różnymi osobami. Jako narzędzie diagnostyczne i badawcze, analiza interakcji jest bardzo złożona. 
Szczegółowy plan pracy i detale metodologiczne można dostosowywać do potrzeb i możliwości.

$\mathrm{Na}$ koniec warto nadmienić, że porównanie interakcji dziecko-rodzic versus dziecko-klinicysta, a także interakcji dziecka $\mathrm{z}$ każdym $\mathrm{z}$ rodziców, dostarcza ważnych informacji o tym, jakie kompetencje dziecko pokazuje w różnych kontekstach relacyjnych. Ujmując w pewnym uproszczeniu, oceniamy, czy w którejś interakcji dziecko „wypada” lepiej albo gorzej. Czy $\mathrm{w}$ danej interakcji pojawiają się zachowania nieobecne w kontakcie z innymi osobami? Zwracamy uwagę na to, jakie zachowania interakcyjne bądź ogólne cechy interakcji sprzyjają, a jakie utrudniają dziecku optymalne funkcjonowanie. W zależności od celu analizy i wybranych ram teoretycznych, możemy wnioskować o jakości relacji dziecko-osoba. Oczywiście wyciąganie wniosków jest możliwe dopiero po uwzględnieniu informacji o zachowaniu innych uczestników interakcji.

2.2.2. Poziom osoby: rodzic. Opisując zachowanie rodzica, możemy posługiwać się istniejącą terminologią (zob. np. Belsky, Jaffee, Sligo, Woodward, Silva, 2005; Bornstein, 2002; Bornstein, Tamis-LeMonda, Hahn, Haynes, 2008; Ryan, Martin, Brooks-Gunn, 2006). Poniżej przedstawiam wybór terminów, które są przydatne w analizie interakcji według zaprezentowanego w dalszej części książki schematu.

1. Reagowanie na zachowanie dziecka

Wrażliwość i responsywność

Podążanie

Komentowanie, nazywanie

Pomaganie, współdziałanie

2. Uwaga

Uważna obserwacja

Wzmożona czujność

Pozytywna versus negatywna uwaga

3. Wpływanie na zachowanie dziecka

Nadawanie struktury

Formułowanie zakazów i nakazów

Konsekwentne reagowanie

Wspieranie rozwoju w różnych sferach

Dyrektywność i kontrola

Intruzywność 
4. Jakość emocjonalna

Okazywanie czułości

Odzwierciedlanie, współczucie

Ogólny afekt

Dystans, wycofanie

Wrogość, szorstkość

Jednym z najczęściej używanych terminów opisujących zachowania rodzicielskie jest wrażliwość (Ainsworth, 1969), czyli umiejętność dostrzegania komunikatów dziecka. Pokrewnym terminem jest responsywność, oznaczająca adekwatne reagowanie na te komunikaty. Ponieważ cechy te są ze sobą ściśle związane, często mówi się o wrażliwej responsywności (sensitive responsiveness). Jest to umiejętność dostrzeżenia zachowania dziecka oraz właściwego zareagowania na nie. Jeżeli dziecko wskazuje na przedmiot, zachowaniem rodzica świadczącym o wrażliwości będzie spojrzenie w kierunku wskazywanym przez dziecko. Jeżeli dziecko wyciąga rękę w kierunku zabawki i wykonuje chwytający ruch dłoni, o responsywności będzie świadczyć podanie jej dziecku. Wrażliwa responsywność wymaga zarówno umiejętności rozumienia obserwowanych zachowań dziecka i potrzeb, jakie zachowania te wyrażają, jak i dostosowania swoich reakcji do tych zachowań, z uwzględnieniem poziomu rozwoju dziecka i kontekstu. Informacje o narzędziach służących do oceny wrażliwości i responsywności Czytelnik znajdzie w rozdziale 2.3.

Zachowania rodzicielskie zwykle oceniamy na pewnym kontinuum. Określamy stopień nasilenia, np. od bardzo niskiej i niskiej, przez średnią i wysoką, do bardzo wysokiej wrażliwości. Jest to odpowiednik stosowanej w badaniach naukowych skali porządkowej (Likerta). Opisując zachowanie w taki sposób, unikamy nadmiernych uproszczeń, które wynikają z dychotomicznych podziałów (np. jest albo nie jest wrażliwy).

Reagowanie na aktywność dziecka w sposób, który nie zmienia jego zachowania, nazywamy podążaniem. Aby podążać, dorosły musi dostosowywać swoją aktywność do aktywności dziecka. Ważną formą podążania, a także włączania się w aktywność dziecka, jest nazywanie (zachowań dziecka, przedmiotów, na które patrzy) i komentowanie. Podążanie sprzyja współdziałaniu, ważnej rozwojowo formy aktywności diadycznej. Jedną z form współdziałania jest pomaganie. Częstość i sposób udzielania dziecku pomocy zależą od wrażliwości i responsywności rodzica oraz jego umiejętności podążania. 
Pożądaną umiejętnością osób, które partnerują dziecku w interakcjach, jest uważna obserwacja. Stanowi ona wzrokowy odpowiednik uważnego słuchania. Taki rodzaj uważności różni się od uwagi nasyconej lękiem czy niepokojem, którą określam tu wzmożoną czujnością. Z perspektywy obserwatora rodzic ze wzmożoną czujnością sprawia wrażenie, jakby oczekiwał, że stanie się coś złego, że będzie musiał reagować na jakieś negatywne czy zagrażające wydarzenie. Uwagę rodzica można również określić ze względu na jej obiekt: pożądane (uwaga pozytywna) i niepożądane zachowania dziecka (uwaga negatywna).

Jak opisałam wcześniej, w toku rozwoju dziecko nabywa coraz większe kompetencje $\mathrm{w}$ zakresie kształtowania interakcji. W okresie wczesnego dzieciństwa to rodzic w większym stopniu nadaje strukturę czy też ramy interakcjom (scaffolding), chociaż wkład dziecka jest obecny od urodzenia. W oryginalnym znaczeniu scaffolding oznaczał strategie wspierania dziecka w sytuacji rozwiązywania problemu i nawiązywał bezpośrednio do teorii Wygotskiego (Wood, Bruner, Ross, 1976). Obecnie rozumiemy je szeroko jako różne zachowania rodzica, które wspierają aktywność dziecka. Nadawanie struktury pomaga dziecku organizować swoją aktywność, a także może służyć wspieraniu rozwoju dziecka w różnych sferach. Na najbardziej podstawowym poziomie strukturyzowanie polega na zapewnieniu odpowiednich warunków dla interakcji (obejmujących m.in. przestrzeń, natężenie różnych dźwięków, fizyczną dostępność partnerów interakcji). Nadawaniem struktury jest także udostępnienie zabawek i innych materiałów, z którymi dziecko ma styczność, włączenie innych osób w interakcje, umożliwianie podejmowania różnych form aktywności. Wreszcie, rodzic może nadawać strukturę interakcjom poprzez modelowanie, demonstrowanie, tłumaczenie, instruowanie itd. Strukturyzowanie nie jest tym samym co kontrola, która ma na celu podporządkowanie działań dziecka woli dorosłego. Dyrektywne zachowania, takie jak polecenia, zakazy, odbieranie zabawek czy usilne próby przekierowania uwagi dziecka, służą zmianie zachowania wbrew jego intencjom. W skrajnej formie przybierają formę zachowań intruzywnych. Formułowanie zakazów i nakazów jest formą kontroli niezbędną dla zachowania bezpieczeństwa, a także socjalizacji dziecka. Ważne jest obserwowanie, w jaki sposób rodzic komunikuje zakazy i nakazy (ton emocjonalny, jasność, poziom szczegółowości, uzasadnianie) oraz czy w swoich zachowaniach jest konsekwentny, tzn. na podobne zachowania dziecka w podobnych warunkach zwykle reaguje w podobny sam sposób. 
Nie mniej ważną właściwością zachowań rodzicielskich jest ich jakość emocjonalna. Obserwujemy, jaki ogólny afekt rodzic wprowadza do interakcji, jakimi emocjami wysycone są jego zachowania, jak często i w jaki sposób okazuje - wprost i nie wprost - różne emocje. Ważne jest również natężenie emocji, ich adekwatność do sytuacji oraz ewentualne sprzeczności w ich wyrażaniu. W rozdziale 3. opisałam znaczenie odzwierciedlania w rozwoju dziecka. Ważne, aby zaobserwować, czy rodzic dostrzega stan emocjonalny dziecka. Czy jest w stanie go zrozumieć? Czy towarzyszy dziecku w przeżywaniu różnych emocji? W jaki sposób? Czy odzwierciedlane są wszystkie stany emocjonalne dziecka, czy tylko niektóre?

Wkład rodzica w strukturę interakcji analizujemy analogicznie do zachowań dziecka. Pytamy, w jaki sposób rodzic inicjuje, podtrzymuje i kończy interakcje. Jak odpowiada na inicjatywy dziecka? W jaki sposób akceptuje i odmawia? Jak włącza dziecko w swoją aktywność? Czy jego komunikaty są zrozumiałe dla obserwatora? Czy zdają się zrozumiałe dla dziecka (co wskazuje na to, że dziecko rozumie komunikaty rodzica)? Ponadto należy zwrócić uwagę na tempo. Jak szybko rodzic reaguje na zachowanie dziecka, wykonuje czynności pielęgnacyjne i opiekuńcze? Jak często zmienia aktywność? Czy tempo rodzica jest dostosowane do tempa dziecka?

Zwięzły opis różnych pożądanych zachowań osób dorosłych w sytuacji nawiązywania kontaktu z dzieckiem przedstawia Frydrychowicz (1991).

Na koniec chciałabym zwrócić uwagę na samopoczucie osób dorosłych w sytuacji obserwacyjnej. Dorośli znacznie częściej niż dzieci mogą odczuwać napięcie, będąc obserwowanymi. Jednym ze źródeł napięcia może być lęk przed nieznanym. Sytuacja, w której profesjonalista przygląda się interakcjom dziecko-rodzic, jest nietypowa. Dla większości rodziców jest to pierwsze takie doświadczenie. Ważne zatem, aby dokładnie poinformować uczestników, w jaki sposób będzie przebiegać obserwacja, m.in. przedstawić informację o pomieszczeniu i jego wyposażeniu, czasie trwania obserwacji, form aktywności, które będą dostępne, obecności innych osób czy planowanym użyciu sprzętu do rejestracji dźwięku lub obrazu. Należy unikać obserwowania uczestników w niekomfortowej dla nich sytuacji.

Kolejne obawy dorosłych związane z obserwacją ich interakcji z dzieckiem wynikają z lęku przed oceną. Mogą oni obawiać się, że klinicysta stwierdzi, że nie są „dobrymi” rodzicami. Można się spodziewać, że lęk ten będzie tym większy, im więcej będzie zależeć od wyniku diagnozy. Jednak często występuje on nawet w przypadku badań naukowych, kiedy to uczestnicy wiedzą, że interakcje będą analizowane z zachowaniem anonimowości 
(badacze nie posługują się nazwiskami), a dane będą analizowane zbiorczo (dla całej grupy uczestników).

Poziom lęku jest zarówno względnie stałą cechą, jak i przejściowym stanem w danej sytuacji. Wysoka jakość kontaktu z klinicystą czy badaczem służy redukcji poziomu lęku sytuacyjnego i odpowiedzialny jest za nią profesjonalista. Ponadto prowadzenie wielokrotnych obserwacji pozwala uczestnikom zaadaptować się do sytuacji, co obniża poziom lęku przy kolejnych spotkaniach. Analiza nagrań wykonanych w domu czy innym naturalnym dla uczestników otoczeniu również może dostarczyć informacji o tym, jak bardzo zachowanie w gabinecie różni się zachowania w codziennych sytuacjach. Ponadto, aby ocenić poziom i rolę lęku, można wykorzystać odpowiednie kwestionariusze (np. STAI; Spielberger, Strelau, Tysarczyk, Wrześniewski, 1987) czy rozmowę psychologiczną.

Pomimo zastrzeżeń wynikających z możliwości wzbudzenia u osób dorosłych oraz starszych dzieci lęku przed oceną w sytuacji obserwacyjnej, jest mało prawdopodobne, aby zachowanie podczas obserwacji całkowicie różniło się od zwyczajowego zachowania. Wynika to z faktu, że wzorce zachowań interakcyjnych są utrwalone, a zatem mają charakter nawykowy i nie podlegają łatwej modyfikacji pod wpływem czynników sytuacyjnych (z wyjątkiem sytuacji ekstremalnych). Niektóre dane wskazują jednak, że pewne aspekty zachowania mogą się różnić podczas obserwacji w warunkach domowych i w gabinecie klinicysty czy w laboratorium (Gardner, 2000). Należy uwzględnić taką możliwość w procesie nadawania znaczenia obserwowanym zachowaniom, szczególnie jeżeli obserwacje miały miejsce wyłącznie poza naturalnym środowiskiem osób badanych. Ponieważ nasze interpretacje mogą być niepełne, a nawet błędne, formułowane opinie i wnioski muszą być ostrożne i uwzględniać informacje o ograniczeniach wynikających z procedury obserwacyjnej.

2.2.3. Poziom osób: diada dziecko-rodzic. Analiza interakcji dziecko-rodzic w kontekście klinicznym różni się od diagnozy psychologicznej poszczególnych osób. Analogicznie jest w badaniach naukowych - narzędzie to różni się od narzędzi polegających na zbieraniu danych na poziomie jednostek. Zarówno w diagnozie, jak i w badaniach naukowych, inne są założenia, procedury oraz rodzaj wyników.

Kluczowym założeniem analizy interakcji jest istnienie dwukierunkowych zależności między uczestnikami. Osoby wzajemnie wpływają na swoje zachowanie, kształtując przebieg interakcji. Zgodnie z teorią systemów 
dynamicznych, efekt końcowy (działanie systemu) nie jest prostą sumą elementów, które ten system budują, lecz produktem wyłaniającym się z ich współdziałania (Granic, Hollenstein, 2003; Smith, Thelen, 2003). Oznacza to, że nie można przewidzieć przebiegu interakcji, nawet jeżeli znane są cechy osobowości każdego z uczestników.

Z wymienionych założeń wynika konieczność stosowania określonych procedur zbierania danych obserwacyjnych. Muszą one być dopasowane do wszystkich uczestników interakcji, tzn. każda z osób powinna mieć możliwość swobodnej ekspresji behawioralnej. Ponadto, jeżeli interakcje mają być rejestrowane, urządzenia nagrywające muszą być zainstalowane w taki sposób, aby widoczne były sylwetki wszystkich uczestników i otoczenie. Zarazem rozmiar i umiejscowienie tych urządzeń nie powinny ograniczać ich aktywności.

Wyniki analizy interakcji mają specyficzny charakter. Po pierwsze, złożoność opisu jest znacznie większa niż w przypadku analiz dotyczących jednostek. Po drugie, przyczynowość w interakcjach jest cyrkularna - często trudno jest stwierdzić, które zachowanie było początkiem sekwencji i przyczyną dalszych wydarzeń. Dlatego też wyniki analizy interakcji są złożone. Wnioskowanie wymaga od klinicysty uwzględniania i łączenia wielu informacji na różnych poziomach, a w badaniach naukowych stosowania zaawansowanych technik rejestracji i przetwarzania danych (zob. rozdział 2.3.3). Chociaż interpretacja wyników analizy interakcji to pracochłonny proces, uzyskany obraz jest bardziej adekwatnym opisem rzeczywistości niż analiza zachowania osób oderwana od kontekstu interakcyjnego.

Aby zobrazować różnicę między analizą na poziomie jednostek i na poziomie diady, przytoczę przykład obserwacji kontaktu wzrokowego dziecka z rodzicem. W odniesieniu do dziecka możemy zadać pytanie, czy dziecko inicjuje kontakt wzrokowy. Pytanie to dotyczy zachowania, które świadczy o pewnej kompetencji dziecka. W odniesieniu do rodzica możemy zapytać, w jaki sposób reaguje on, kiedy dziecko próbuje nawiązać kontakt wzrokowy. Jest to pytanie o wrażliwą responsywność. Jeśli chodzi o diadę, pytamy, czy i w jaki sposób diada nawiązuje kontakt wzrokowy. Istotą jest tu ustalenie, czy dziecko i rodzic potrafią skoordynować swoje zachowania (dziecko - inicjowanie, rodzic - odpowiadanie) w taki sposób, że udaje się im doprowadzić do epizodu kontaktu wzrokowego. Na bardziej szczegółowym poziomie można rozważyć specyficzne zachowania, które składają się na inicjowanie kontaktu wzrokowego przez dziecko (np. skierowanie wzroku w okolice oczu rodzica, uśmiech, wokalizacja) i na reakcje rodzica (np. 
skierowanie wzroku w okolice oczu dziecka, uśmiech, komentarz słowny), sekwencje tych zachowań i ich nakładanie się, czas trwania, latencje itd.

Z przytoczonego przykładu wynika, że aby doszło do kontaktu wzrokowego, nie wystarczy, aby każda z osób popatrzyła w okolice oczu drugiej osoby (koordynacja przestrzenna). Pozostaje jeszcze koordynacja działań w czasie: oboje muszą w tym samym czasie utrzymywać uwagę wzrokową w okolicach oczu partnera interakcji. Jeżeli wystąpi tylko koordynacja przestrzenna, ale nie czasowa, zaobserwujemy, że raz jedna, raz druga osoba patrzy w okolice oczu partnera interakcji. Może to oznaczać, że dziecko monitoruje uwagę wzrokową rodzica, a rodzic dziecka. Natomiast jeżeli obecna będzie koordynacja czasowa, ale nie przestrzenna, partnerzy będą patrzeć na siebie bez kontaktu wzrokowego, np. rodzic będzie obserwował dziecko, a dziecko przedmiot, który rodzic trzyma w ręce. Z kolei jeżeli rodzic i dziecko skoordynują przestrzennie i czasowo swoją uwagę wzrokową, tak, że nastąpi kontakt wzrokowy, po czym rodzic przeniesie uwagę na inny obiekt, stwierdzimy, że rodzic zakończył epizod kontaktu wzrokowego.

$\mathrm{W}$ analizie interakcji przyglądamy się, w jaki sposób zachowania poszczególnych uczestników budują zachowania diadyczne. Odwołując się do podejścia ekologicznego (Gibson, 1979/2014; Gibson, 1982; Gibson, Schmuckler, 1989), możemy opisywać zachowania w terminach „afordancji” (affordances; możliwości, które daje środowisko ${ }^{9}$ ) i ograniczeń (constraints; cech środowiska, które zawężają możliwości działania). Pewne zachowania rodzica umożliwiają, a inne ograniczają repertuar zachowań dostępnych dziecku i vice versa. Na przykład zbliżenie twarzy opiekuna do twarzy niemowlęcia, które leży w foteliku samochodowym, umożliwia dziecku przyjrzenie się tej twarzy, dotknięcie jej i nawiązanie kontaktu wzrokowego. Jednocześnie dziecko ma ograniczone możliwości wycofania się z interakcji, ponieważ nie jest w stanie odwrócić się całym ciałem ani wyswobodzić z fotelika. Analogicznie, ufna więź umożliwia dziecku swobodną eksplorację nowego otoczenia w obecności opiekuna, ale ogranicza możliwość długotrwałego rozstania się z nim bez skutków w postaci reakcji protestu, rozpaczy i żałoby (por. Bowlby, 1969/2007). Z każdym zachowaniem interakcyjnym uczestnicy wspólnie tworzą środowisko, ze wszystkimi możliwościami i ograniczeniami, które podlega ciągłym zmianom wraz z rozwojem osób.

Tak jak w odniesieniu do jednostek, zachowania diady możemy opisać za pomocą bardzo szerokiej i zróżnicowanej terminologii. Jej wybór

9 W tej książce afordancje będę nazywała możliwościami. 
podyktowany jest przyjmowanymi ramami teoretycznymi i celowi analiz. Proponuję, aby w pierwszej kolejności zwrócić uwagę na przedstawione poniżej grupy zachowań diadycznych i cech interakcji.

1. Ilość i jakość kontaktu za pomocą różnych zmysłów

Dotyk i kontakt fizyczny, proksemika

Słuch i kontakt werbalny

Wzrok (uwaga wzajemna, równoległa, wspólna i podzielana; kierowanie uwagą drugiej osoby)

2. Aktywność i jej cele

Rodzaj i zróżnicowanie aktywności

Aktywność wspólna, równoległa, kolidująca

Cele wspólne, rozbieżne, kolidujące

Decydowanie o formie aktywności i uzgadnianie jej celów

3. Emocje

Kierowane do drugiej osoby

Podzielane

4. Dopasowanie interakcyjne

Koordynacja

Synchronia

Naprawy interakcyjne

Diada może nawiązywać, utrzymywać i przerywać kontakt za pomocą różnych zmysłów. Analizując interakcje, bierzemy pod uwagę sprawność i poziom rozwoju narządów zmysłu dziecka i rodziców. Przyglądamy się temu, jak często i w jakich momentach interakcji uczestnicy używają różnych zmysłów, aby się komunikować, utrzymywać bliskość lub dystans. Zastanawiamy się, jakie rodzaje komunikatów uczestnicy przekazują za pomocą poszczególnych modalności oraz analizujemy sekwencje zachowań pod kątem wykorzystywanych zmysłów (np. rodzic dotyka dziecka $\rightarrow$ dziecko spogląda na rodzica $\rightarrow$ dziecko wokalizuje $\rightarrow$ rodzic mówi do dziecka).

Proksemika dotyczy fizycznej odległości między osobami. Odległość ta jest ważnym wskaźnikiem rodzaju i jakości łączącej ich relacji. Regulacja proksemiki to ważne narzędzie regulacji dystansu psychicznego, akcentowane w teorii przywiązania. Zbliżanie się, oddalanie i unikanie mają bowiem swoistą dynamikę, zależną od wieku dziecka, obecności osób (rodziców, obcych), ich zachowania oraz wzorców przywiązania. Przyglądając się diadzie, analizujemy rodzaj i funkcję zachowań zmniejszających i zwiększających 
dystans między uczestnikami, formy utrzymywania bliskości za pomocą różnych zmysłów oraz unikania jej.

Kontakt za pomocą wzroku podlega szczegółowej analizie ze względu na jego rolę w rozwoju umysłowym dzieci widzących. Zmiany rozwojowe $\mathrm{w}$ posługiwaniu się uwagą są związane $\mathrm{z}$ nabywaniem kluczowych umiejętności komunikacyjnych, rozwojem teorii umysłu, uczeniem się i szeroką gamą kompetencji społecznych. Ontogenetycznie pierwszym rodzajem uwagi diadycznej jest uwaga wzajemna, czyli na poziomie behawioralnym patrzenie na siebie (z kontaktem wzrokowym lub bez). Drugi rodzaj to uwaga równoległa, czyli na poziomie behawioralnym jednoczesne patrzenie na ten sam obiekt (Gaffan, Martins, Healy, Murray, 2010), któremu może towarzyszyć wspólna aktywność na tym obiekcie. Wreszcie, pod koniec 1. roku życia wyłania się uwaga wspólna. Wiąże się ona z możliwością kierowania uwagi partnera interakcji na obiekty. Zachowaniami, które tworzą epizody wspólnej uwagi są np. naprzemienne patrzenie na przedmiot i na osobę, z nawiązywaniem kontaktu wzrokowego, czy wskazanie palcem przedmiotu, zwykle również połączone z nawiązaniem kontaktu wzrokowego. Warto zatem obserwować, w jaki sposób osoby konstruują epizody uwagi diadycznej.

W sytuacji obserwacyjnej diady zwykle podejmują celową aktywność: dowolną lub narzuconą przez obserwatora. W interakcji swobodnej obserwujemy formę i zróżnicowanie aktywności (np. zabawa i jej rodzaje, poznawanie otoczenia i uczenie się, czynności związane z codziennym funkcjonowaniem, modyfikowanie środowiska). W przypadku aktywności wspólnej warto zaobserwować, w jaki sposób rodzice i dziecko uzgadniają wybór aktywności i jej cel. Aktywność diady może mieć również charakter równoległy, kiedy to osoby podejmują odrębne działania, jednocześnie pozostając we względnej bliskości fizycznej (np. rodzic czyta książkę, a dziecko buduje z klocków). W obserwacji przyglądamy się reakcjom każdej z osób na taką niezależność partnera interakcji oraz proporcji aktywności wspólnej i równoległej. Cele i aktywność mogą również ze sobą kolidować, kiedy na przykład rodzic próbuje nakarmić dziecko, a ono ucieka i podejmuje zabawę. Zwracamy uwagę na to, w jaki sposób rodzic i dziecko negocjują ostateczne cele i formy aktywności.

Wszystkie zachowania diady wysycone są emocjami, choć nie zawsze łatwo zinterpretować ich sygnały. W analizie skupiamy się na tym, które emocje są kierowane (adresowane) do drugiej osoby, a które nie. Adresowanie jest czytelne, kiedy ekspresji emocji towarzyszy skierowanie wzroku na drugą osobę, zbliżenie się do niej czy komunikat werbalny. Szczególną formą 
zachowania diadycznego jest podzielanie emocji, czyli współprzeżywanie po tym, jak uczestnik lub uczestnicy je do siebie zaadresują. Przykładem zainicjowania podzielania emocji jest spojrzenie na rodzica $\mathrm{z}$ uśmiechem, po zbudowaniu wieży z klocków. Jeżeli rodzic zareaguje np. podtrzymaniem kontaktu wzrokowego, uśmiechem i komentarzem „Jaką wieżę zbudowałeś!”, będziemy mówić o epizodzie podzielania radości. W diadach nie wszystkie emocje są zawsze jasno kierowane do partnera interakcji czy podzielane. Warto przyjrzeć się ewentualnym wzorcom i prawidłowościom w tym zakresie.

Opisane powyżej zachowania składają się na dopasowanie interakcyjne. Mówiąc o dopasowaniu, praktycy i badacze używają różnych bardziej lub mniej nakładających się na siebie terminów, takich jak: koordynacja, synchronia, spójność, zgranie czy dostrojenie (przegląd w: Harrist, Waugh, 2002). Uczestnicy interakcji dokonują na bieżąco, z chwili na chwilę, dopasowań swojego zachowania (moment-to-moment adjustments; Granic, Hollenstein, 2003; Patterson, Reid, 1984). Interakcje wymagają zgrania zachowań pod względem czasoprzestrzennym i treściowym, co wymaga ciągłego wzajemnego obserwowania się. Ponadto konieczne jest ciągłe negocjowanie przebiegu interakcji. Osoby dostosowują się do zachowań partnera, ale również powodują, że druga osoba się dostosowuje. Nieuniknione są pewne nieporozumienia, momenty braku koordynacji i spójności treściowej. Mogą one wynikać np. z niezrozumienia komunikatu drugiej osoby czy rozbieżności celów i polegać na niespójności stanów emocjonalnych, kolizji linii aktywności, nakładaniu się pewnych zachowań (np. jednoczesnym mówieniu) itd. Jak podają Tronick i Gianino (1986) w pierwszym roku życia dziecka niedopasowanie może stanowić nawet 70\% czasu interakcji. Zależy to jednak w znacznej mierze od przyjętych kryteriów oceny dopasowania. O kompetencjach diady świadczy nie tyle obecność epizodów niedopasowania, lecz jej zdolność do dokonywania napraw w toku interakcji (interactive repairs; Tronick, 1989), czyli osiągania (czasowej) synchronii stanów lub zachowań (Bosco, Bucciarelli, Bara, 2006).

Aby przyjąć klocek podawany przez rodzica, dziecko musi zauważyć, że trzyma go on w ręce i wyciąga rękę z przedmiotem w jego stronę. Następnie musi zinterpretować to zachowanie jako chęć przekazania mu przedmiotu (np. dlatego, że jednocześnie rodzic patrzy na dziecko i się uśmiecha), wyciągnąć własną rękę we właściwym kierunku i chwycić przedmiot. Przekazanie klocka może się nie udać, jeżeli rodzic cofnie rękę, zanim dziecko zauważy jego zachowanie, odczyta intencję i zareaguje. Rodzic i dziecko mogą 
naprawić interakcję, jeśli np. dziecko, wyciągając w stronę rodzica rękę, wyda odgłos niezadowolenia, a w odpowiedzi rodzic ponownie poda mu przedmiot. Do przyjęcia przedmiotu może również nie dojść, jeżeli dziecko go nie zechce, jak choćby wtedy, gdy rodzic podaje żółty klocek, podczas gdy dziecko planuje zbudować wieżę wyłącznie z zielonych klocków. Byłoby to nieporozumienie, brak dopasowania. Jeżeli dziecko odepchnie rękę rodzica, a ten zinterpretuje to jako odmowę i skomentuje „Nie chcesz”, na co dziecko przytaknie, będzie to naprawa interakcyjna.

2.2.4. Poziom osób: triada dziecko-rodzice. Jeszcze bardziej złożoną formą interakcji są interakcje triadyczne, czyli takie, w których biorą udział trzy osoby. Interakcje w triadzie dziecko-matka-ojciec są dla wielu niemowląt naturalnym kontekstem rozwoju, jednak wymagają od uczestników szczególnych kompetencji. Fivaz-Depeursinge (2008) wśród cech pozytywnej interakcji dziecko-matka-ojciec wymienia uwzględnianie wszystkich trzech osób i aktywny udział każdej z nich, wspólne pole uwagi, dostrojenie oraz podzielanie pozytywnych emocji. Z punktu widzenia niemowlęcia największym wyzwaniem wydaje się kontrola uwagi - przenoszenie jej między dwoma partnerami interakcji, a także utrzymywanie w pamięci większej ilości informacji niż podczas interakcji diadycznej. Rodzice mogą ułatwiać dziecku to zadanie, koordynując swoje działania względem niego.

W badaniu podłużnym wykazano, że zachowania interakcyjne dzieci w wieku 4 lat (inicjowanie zachowań naprzemiennych) i rodziców (reagowanie na te inicjacje) podczas interakcji triadycznych były związane z poziomem umiejętności społecznych tych dzieci w wieku 15 lat (Hedenbro, Rydelius, 2019). Zatem kompetencje triadyczne są predyktorem dalszego rozwoju społecznego. Ze względu na przewagę badań nad interakcjami diadycznymi, mechanizmy wpływu jakości interakcji w triadzie na rozwój dziecka są stosunkowo mało poznane. Zagadnienie to wymaga dalszych badań.

Niemowlętom może być trudno uwzględniać w interakcji więcej niż dwie osoby. Nie oznacza to, że nie są one w stanie przebywać w większym gronie. Jednak w danym momencie aktywnie uczestniczą raczej w interakcji diadycznej lub triadycznej, a nie w interakcji z większą liczbą osób. Wraz $\mathrm{z}$ wiekiem umiejętność angażowania się $\mathrm{w}$ interakcje w grupie rośnie. Ze względu na cel analiz korzystne może być przeanalizowanie interakcji w całej najbliższej rodzinie dziecka, np. obejmującej wszystkie osoby mieszkające w tym samym gospodarstwie domowym. Obserwując triady, tetrady czy jeszcze większe systemy, przyglądamy się również interakcjom diadycznym 
w ich obrębie. Analizujemy diady dziecko-matka, dziecko-ojciec, matka-ojciec, dziecko-dziecko, dziecko-obserwator itd. Chociaż zarówno obserwacja, jak i późniejsza interpretacja zachowań wielu osób stanowi duże wyzwanie, daje ona najwierniejszy obraz funkcjonowania rodziny. Ponadto można zaobserwować, w jaki sposób rodzina przyjmuje osoby z zewnątrz, w tym wypadku obserwującego klinicystę lub badacza. Podejście takie jest zgodne z systemowym rozumieniem relacji rodzinnych (synteza informacji w: de Barbaro, 1999).

Z połączenia zachowań poszczególnych osób w różnych konfiguracjach w czasie i w przestrzeni powstaje cała różnorodność zachowań interakcyjnych. Analizując interakcje, przyglądamy się, w jaki sposób dziecko i rodzice kształtują ich przebieg. Zachowanie każdej z osób tworzy kontekst dla zachowania partnerów interakcji i vice versa, a jednocześnie zależy od czynników indywidualnych. Dlatego też każda diada, triada czy tetrada jest wyjątkowa i ma specyficzne dla niej wzorce interakcji. Obserwując interakcje dziecka $\mathrm{z}$ rodzicami i innymi osobami w jego życiu, uzyskujemy dostęp do zbioru wzorców zachowań, które mają kluczowe znaczenie w jego rozwoju osobowym.

Aby uporządkować zbierane informacje, Czytelnik może zastosować przedstawioną w Załączniku A Kartę oceny interakcji.

\subsection{Schematy oceny stosowane $w$ analizie interakcji dziecko-rodzic}

2.3.1. Mikro- i makroanaliza interakcji. Analiza interakcji dzieckorodzic(e) umożliwia poszukiwanie odpowiedzi na szereg pytań badawczych dotyczących mechanizmów typowego i nieprawidłowego rozwoju oraz trajektorii rozwoju, czynników ryzyka i czynników chroniących przed zaburzeniami rozwoju, predyktorów osiągnięć rozwojowych, różnic wewnątrzi międzyosobowych oraz międzygrupowych, a także optymalnych w różnych kontekstach zachowań rodzicielskich. Syntetyczne wprowadzenie do analizy interakcji jako narzędzia badawczego Czytelnik znajdzie w pracy Aspland i Gardner (2003).

Ogólnie ujmując, istnieją dwa podejścia w badaniach interakcji dzieckorodzic: mikroanalityczne i makroanalityczne. Mikroanaliza polega na kodowaniu specyficznych zachowań w małych jednostkach czasu (zwykle poniżej 1 s.). Przykładem jest kodowanie zachowań uwagowych, np. patrzenia na 
osoby versus przedmioty klatka po klatce. Mikroanaliza najlepiej się sprawdza, kiedy dotyczy możliwych do wyodrębnienia i policzalnych zachowań, np. liczby spojrzeń, czasu patrzenia. Jak pisze Beebe (2017, s. 4), „mikroanaliza działa jak społeczny mikroskop dający wgląd w świat, który widziany w czasie rzeczywistym jest niedostępny percepcyjnie". Mikroanaliza ujawnia zachowania o krótkim czasie trwania, a także pozwala wyodrębnić poszczególne zachowania składające się na większe całości. Przykłady użycia mikroanalizy w badaniach Czytelnik znajdzie w pracach Beebe (Beebe i in., 2010; Beebe, Steele, 2013), Kmity (2005, 2011), czy Gratier (2003; Gratier i in., 2015). Wymienione właściwości mikroanalizy stanowią o jej wartości jako narzędzia badawczego, jednak wiążą się z dużym nakładem pracy, wymaganym do opracowania nawet krótkich epizodów interakcyjnych. Niezbędne jest także sprzęt do nagrywania - zwykle kilka kamer - oraz odpowiednie oprogramowanie, takie jak programy Observer XT firmy Noldus, INTERACT firmy Mangold, ELAN opracowany przez zespół naukowców z Instytutu Psycholingwistyki Maxa Plancka czy ANVIL opracowany przez Michaela Kippa z Uniwersytetu w Augsburgu. Ponadto osoby kodujące mikroanalitycznie muszą posiadać wysoko rozwiniętą kompetencję obserwacji zachowań dzieci i dorosłych oraz być bardzo cierpliwe i rzetelne. Ze względu na wysokie wymagania sprzętowe i osobowe mikroanaliza znajduje zastosowanie głównie w badaniach naukowych. Zaletą kodowania specyficznych zachowań w sposób mikroanalityczny jest stosunkowa obiektywność oceny - koduje się widoczne zachowania bez nadawania im znaczenia. Subiektywność nie jest jednak całkowicie wyeliminowana, np. sędziowie mogą się nie zgadzać pod względem tego, na co w danym momencie patrzy osoba, jeżeli w jej polu widzenia znajdują się różne obiekty. W mikroanalizie zwykle stosunkowo krótkie epizody interakcyjne traktuje się jako reprezentatywne próbki zachowania osób (ze względu na ograniczone zasoby kodowanie długich epizodów zwykle nie jest możliwe), co jednak nie musi być prawdą.

Makroanaliza polega natomiast na ogólnej ocenie zachowania osób, przy czym zwykle dotyczy nie pojedynczych odrębnych zachowań, lecz ich grup, które odzwierciedlają pewne konstrukty, jak choćby wrażliwość rodzicielska czy afekt. Oceniać można jakość zachowania, np. na skali porządkowej (od bardzo wysokiej wrażliwości, przez średnią do niskiej), czas trwania epizodów, w których zachowanie oceniono jako wrażliwe, lub częstość występowania danej grupy zachowań. Pewnym uproszczeniem jest kodowanie w obrębie przedziałów czasowych, np. dychotomiczna ocena czy w 15-sekundowym przedziale czasowym wystąpiły, czy nie wystąpiły zachowania 
świadczące o wrażliwości. Taki sposób oceny materiału obserwacyjnego może być stosowany zarówno w analizie nagrań, jak i podczas obserwacji na żywo, co jednak nie jest zwykle stosowane w badaniach naukowych ze względu na brak możliwości ponownej oceny materiału. Makroanalitycznym można również nazwać kodowanie specyficznych zachowań (podobnie jak w mikroanalizie), jednak w większej skali czasowej, np. bez spowalniania obrazu. Makroanalizą jest również kodowanie całych wiązek lub sekwencji zachowań, które są składowymi większych jednostek, np. zamiast kodować mikroanalitycznie poszczególne wokalizacje i wypowiedzi uczestników, można zakodować epizod jako „dialog”, zamiast kodować czas patrzenia na obiekty czy osoby i przenoszenie wzroku, można zakodować epizod jako „uwagę wspólną".

Makroanaliza wymaga bardzo dokładnego zdefiniowania konstruktów i ich właściwej operacjonalizacji. Przykładowo wrażliwość rodzicielska może być różnie oceniana i tylko bardzo szczegółowe opisanie zachowań, które są jej wskaźnikami, umożliwia trafną i rzetelną ocenę obserwacji przez osoby kodujące. Po zakodowaniu przez wyszkolonych sędziów kompetentnych dane są stosunkowo łatwe do zinterpretowania - zachowaniom już nadano znaczenie i przypisano wartość (np. stopień nasilenia). W makroanalizie można stosować oprogramowanie takie jak w mikroanalizie, co ułatwia opracowywanie materiału, jednak nie jest to niezbędne. Można na przykład wykorzystywać arkusze oceny lub skale kwestionariuszowe. Ilość uzyskanych danych jest mniejsza niż w mikroanalizie i to od celu analiz zależy, czy jest wystarczająca. Makroanaliza wydaje się bardziej użyteczna w zastosowaniach klinicznych niż mikroanaliza. Ponadto umożliwia kodowanie dłuższych epizodów interakcyjnych w znacznie krótszym czasie.

Tak jak i inne schematy oceny stosowane w badaniach psychologicznych, skale mikro- i makroanalityczne mają trafność i rzetelność (zob. Hornowska, 2001). W pracach wykorzystujących analizę interakcji trafność nie zawsze jest oceniana, natomiast rzetelność podaje się przeważnie jako współczynnik zgodności między sędziami kompetentnymi oceniającymi te same obserwacje. Niektórzy autorzy nie podają żadnych informacji o właściwościach narzędzia, które zastosowali. Wybierając narzędzie do własnego badania, warto zwrócić uwagę na jego właściwości psychometryczne oraz sposób, w jaki zostały one ustalone.

2.3.2. Wybrane schematy oceny stosowane $w$ analizie interakcji. Trudno byłoby wymienić i opisać wszystkie schematy oceny, które 
wykorzystano dotychczas w badaniach nad interakcjami dziecko-rodzic lub rodzice. Część skal do oceny interakcji znalazła swoje stałe miejsce w tym nurcie badawczym, inne opracowano na potrzeby jednego badania i więcej nie były używane. Pewne schematy mają ustalone właściwości psychometryczne, inne - nie. Jednocześnie podejścia teoretyczne leżące u ich podłoża, stosowane konstrukty i ich operacjonalizacja oraz ogólny sposób oceny zachowań w znacznej mierze się pokrywają. Poniżej zostaną przedstawione wybrane systemy kodowania, które zastosowano w opublikowanych pracach. Ponadto opis niektórych narzędzi Czytelnik znajdzie w pracach przeglądowych Mesman (2010), Munson i Odoma (1996) oraz Lotzin i in. (2015).

\subsubsection{Ocena zachowania rodzica.}

2.3.2.1.1. Skale wrażliwości macierzyńskiej Ainsworth. Skale Maternal Sensitivity Scales opracowane przez Mary Ainsworth (1969; Ainsworth i in., 1978/2015) są odzwierciedleniem jej myślenia o uwarunkowaniach ufnego przywiązania. Skale zostały skonstruowane na podstawie dokonanych przez Ainsworth i zespół obserwacji interakcji dzieci i matek w codziennych sytuacjach. Z założenia mają one służyć do oceny interakcji w naturalnym otoczeniu, po obserwacji przez ponad 12 godzin. Kluczowe aspekty zachowania matki Ainsworth pogrupowała w cztery skale: wrażliwość versus niewrażliwość, współdziałanie versus zakłócanie, dostępność fizyczna i psychiczna versus ignorowanie i zaniedbywanie oraz akceptacja versus odrzucanie potrzeb dziecka. Każdy aspekt zachowania wymieniony w nazwie skali ocenia się od 1 do $9 \mathrm{w}$ zależności od nasilenia danej cechy. Wyniki oceny korelują z jakością przywiązania dziecka (wzorzec ufny versus lękowy) ocenianą podczas laboratoryjnej procedury obcej sytuacji (Bretherton, 2013). Ainsworth stwierdziła, że matki dzieci ufnie przywiązanych cechowały się wyższą wrażliwością niż matki dzieci przywiązanych lękowo (Ainsworth, Bell, Stayton, 1971). Skale te niestety nie mają ustalonych właściwości psychometrycznych.

Mesman, Minter i Angnged (2016) rozbudowały skalę wrażliwościniewrażliwości na potrzeby badań z udziałem dzieci, którymi opiekuje się więcej niż jeden dorosły, uwzględniając inne relacje niż tylko matka-dziecko. Narzędzie zawiera zaadaptowaną skalę wrażliwości-niewrażliwości Ainsworth oraz skalę otrzymanej wrażliwości (received sensitivity). Ma ona sumować wrażliwe zachowania wobec dziecka, niezależnie od tego, która osoba z jego otoczenia akurat się nim zajmowała. Zgodność ocen sędziów kompetentnych została wstępnie oceniona jako dobra (tylko w odniesieniu do dwóch nagrań ocenianych przez dwie osoby). 
2.3.2.1.2. Q-set zachowań macierzyńskich. Schematem opracowanym w odniesieniu do badań i skal Ainsworth jest Q-set zachowań macierzyńskich (Maternal Behavior Q-set; Pederson, Moran, 1995; Pederson i in., 1990). Jest to seria stwierdzeń, które obserwator sortuje pod względem stopnia, $\mathrm{w}$ jakim opisują zachowanie matki podczas zwykłych interakcji w domu, np. „Spowalnia tempo; czeka na odpowiedź dziecka podczas interakcji twarzą w twarz”, „Zauważa, kiedy dziecko uśmiecha się i wokalizuje”, „Poszukuje interakcji twarzą w twarz" (Pederson, Moran, 1995, s. 249-250). Ocena polega na uporządkowaniu 90 stwierdzeń od najbardziej do najmniej charakterystycznych dla zaobserwowanych interakcji. Niedoskonałość tego schematu oceny polega na koncentracji na rodzicu. Zachowanie dziecka jest tutaj widziane jedynie jako bodziec, który wyzwala oceniane zachowania rodzica. Narzędzie to było szeroko używane w badaniach, a także adaptowane do sytuacji innej niż domowa (procedury obcej sytuacji; Behrens, Parker, Haltigan, 2011) oraz dla dzieci w wieku przedszkolnym (Posada, Kaloustian, Richmond, Moreno, 2007). Zgodność ocen wyszkolonych sędziów kompetentnych jest wysoka (korelacje o sile powyżej 0,90).

2.3.2.1.3. Skale dostępności emocjonalnej. Bringen ze współpracownikami (Biringen, Robinson, Emde, 2000) opracowała globalne Skale dostępności emocjonalnej (Emotional Availability Scales), które bazują na skalach Ainsworth, jednak mają oceniać ogólny styl behawioralny, a nie poszczególne zachowania rodzica. Koncepcja leżąca u podłoża konstrukcji narzędzia podkreśla rolę dziecka w kształtowaniu interakcji (Biringen, Easterbrooks, 2012). Uwzględniany jest ich dwukierunkowy i wzajemny charakter (Biringen, 2010). Na skali od 1 do 9 ocenia się u rodzica wrażliwość, nadawanie struktury, nie-intruzywność i nie-wrogość, a u dziecka responsywność względem zachowań rodzica i uwzględnianie rodzica w zabawie. Narzędzie to było wykorzystane w wielu badaniach, co pozwoliło potwierdzić jego trafność teoretyczną (przegląd w: Biringen, Derscheid, Vliegen, Closson, Easterbrooks, 2014). Zgodność sędziów kompetentnych jest dobra do wysokiej (współczynniki korelacji wewnątrzklasowej ${ }^{10}$ od 0,79 do 0,92). Szczegółowy opis skal (wersja trzecia) i instrukcje dla oceniających są dostępne w pracy Biringen i in. (2000).

10 Jest to jedna $\mathrm{z}$ miar zgodności sędziów kompetentnych. 
2.3.2.1.4. Macierzyński styl interakcyjny. Narzędzie opracowane przez Calkins, Hungerford i Dedmon (2004) obejmuje ocenę wrażliwości, intruzywności i stymulacji fizycznej dziecka, które składają się na styl interakcyjny rodzica. Narzędzie zostało użyte do oceny zachowania matek wobec niemowląt podczas specyficznych, ustalonych przez badaczki zadań, natomiast w innym badaniu wykorzystano go do oceny zabawy swobodnej (Bernier i in., 2016). W tej ostatniej publikacji uwzględniono jeszcze jedną skalę pozytywnego afektu matki. Ocenia się epizody interakcyjne podzielone na 30-sekundowe interwały. Należy nadmienić, że Calkins i in. (2004) opracowały swoje narzędzie, odwołując się do wcześniejszego badania, w którym oceniano wrażliwość i intruzywność matek (Fish, Stifter, Belsky, 1993), uzyskały jednak wyższe wskaźniki zgodności ocen osób kodujących (kappa powyżej 0,80), co może wskazywać na przewagę nowszego narzędzia.

\subsection{Ocena zachowań rodzicielskich podczas czytania dziec-} $k u$. Istnieją narzędzia opracowane specjalnie do oceny zachowania rodzica w szczególnej sytuacji, jaką jest czytanie dziecku i wspólne zapoznawanie się z treścią książeczek. Jest to aktywność, której rodzic w znacznym stopniu nadaje kształt (kieruje jej przebiegiem i dostarcza informacji), a samo czytanie w przypadku młodszych dzieci pozostaje wyłącznie domeną rodzica. Aktywność ta ma często charakter edukacyjny.

Schwartz (2004) opracowała skalę, którą wykorzystała do oceny zachowań rodziców dzieci w wieku około 12 do 40 miesięcy, takich jak sprawdzanie rozumienia, powtarzanie wypowiedzi dziecka, chwalenie, dopytywanie itd. Nie ustalono właściwości psychometrycznych narzędzia. Podobny, lecz bardziej obszerny i skoncentrowany na języku system zaproponowali Anderson-Yockel i Haynes (1994). Obejmuje on kodowanie pytań typu co, kto, gdzie, kiedy (wh-questions), pytań wymagających odpowiedzi tak lub nie, nakazów lub próśb, nazywania, opisywania udzielania informacji zwrotnej, stosowania wokatyw ukierunkowujących uwagę, stosowania gestów ukierunkowujących uwagę i pauz. System obejmuje również ocenę zachowań dziecka: werbalizacji lub wokalizacji o charakterze komunikacyjnym, odpowiedzi na pytania rodzica i gestów. Zgodność sędziów kompetentnych, liczoną jako proporcję ocen zgodnych do sumy ocen zgodnych i niezgodnych oceniono jako wysoką. Wyniosła 92\% dla zachowań macierzyńskich i 93\% dla zachowań dziecka.

Narzędziem skoncentrowanym na języku jest również protokół do obserwacji czytania książek Kaderavek-Sulzby (Kaderavek-Sulzby Bookreading 
Observational Protocol; Kaderavek, Sulzby, 1998). W założeniu jest to narzędzie diagnostyczne - specjalista zajmujący się rozwojem i terapią mowy i języka dziecka ocenia to, na ile interakcja jest ogólnie udana, trafność doboru książki przez opiekuna, nadawanie struktury, klimat społeczno-emocjonalny i responsywność werbalną, a następnie udziela opiekunowi informacji zwrotnej oraz może sformułować zalecenia odnośnie do terapii mowy i języka dziecka. Jak podają autorki (Kaderavek, Sulzby, 1998), protokół może służyć również do oceny postępów w toku tej terapii. Jak się wydaje, zastosowanie tego narzędzia może być szersze, bowiem protokół strukturyzuje obserwację interakcji dziecko-rodzic w sytuacji zadaniowej i umożliwia ocenę jej jakości. Niestety, protokół nie ma ustalonych właściwości psychometrycznych.

W pracach dotyczących czytania dzieciom stosowano również narzędzia zaczerpnięte $z$ innych badań, obejmujących inne sytuacje zadaniowe. Na przykład Bus, Leseman i Keultjes (2000) w badaniu porównującym zachowania rodziców $\mathrm{z}$ różnych kultur podczas czytania dzieciom użyli systemu opracowanego do oceny zachowań rodziców w sytuacjach zadaniowych, kiedy rozwiązanie problemu przez dziecko wymagało pomocy rodzica (Erickson, Sroufe, Egeland, 1985). W systemie tym ocenia się m.in. wspieranie, jakość pomocy, poszanowanie autonomii czy wrogość. Nie podano właściwości psychometrycznych tego systemu.

2.3.2. 1.6. Kwestionariusz responsywności macierzyńskiej. Kwestionariusz responsywności macierzyńskiej (Maternal Responsiveness Questionnaire; Leerkes, Qu, 2017) zasadniczo różni się od innych opisywanych tu narzędzi, ponieważ oceny dokonuje sama matka lub inny opiekun dziecka. Osoba badana wypełnia kwestionariusz zawierający pytania o sposób, w jaki reaguje na zachowania niemowlęcia (głównie płacz), także w sytuacjach, kiedy zajęcie się dzieckiem oznacza porzucenie obecnie wykonywanej czynności. Spośród trzech empirycznie wyłonionych podskal: responsywności, odroczonej responsywności i nieresponsywności, ta ostatnia okazała się najtrafniejsza. Należy zauważyć, że wyniki w podskali nieresponsywności słabo lub umiarkowanie ujemnie korelowały z obserwacyjne ocenionym poziomem wrażliwości. Może to oznaczać, że konstrukty wrażliwości i responsywności (tak, jak je zoperacjonalizowano w cytowanej pracy) tylko w niewielkim stopniu się pokrywają. Może to również znaczyć, że ocena własnego zachowania wobec dziecka tylko w ograniczonym stopniu jest spójna $\mathrm{z}$ oceną dokonywaną przez niezależnego obserwatora. Ustalono podstawowe 
właściwości psychometryczne narzędzia (trafność, rzetelność - współczynnik korelacji wewnątrzklasowej wyniósł 0,87, oraz strukturę czynnikową), co jest ważną zaletą kwestionariusza.

\subsection{Ocena jakości interakcji opiekun-dziecko dla niemowląt} i małych dzieci. Narzędzie do oceny jakości interakcji opiekun-dziecko dla niemowląt i małych dzieci (Quality of Caregiver-Child Interactions for Infants and Toddlers; Atkins-Burnett i in., 2015) służy do oceny interakcji dzieci z osobami innymi niż rodzice, np. opiekunami w żłobkach. Może znaleźć zastosowanie w doskonaleniu personelu różnych instytucji opiekuńczo-wychowawczych, stąd koncentracja na zachowaniach dorosłego oraz duży nacisk na aspekt nauczania w interakcjach. Narzędzie zawiera cztery podskale: wspieranie rozwoju społeczno-emocjonalnego (np. odpowiadanie na sygnały emocjonalne, nadzorowanie lub dołączanie do zabawy i innych aktywności), wspieranie rozwoju poznawczego (np. wspieranie eksploracji obiektów, nadawanie struktury podczas rozwiązywania problemów), wspieranie rozwoju językowego i czytelnictwa (np. stosowanie zróżnicowanego słownictwa, angażowanie dziecka w zabawy z książkami), niepokojące zachowania opiekuna (np. szorstkość, niedopasowanie afektywne). Jest ono w całości dostępne, wraz z podręcznikiem, w formie elektronicznej. Jest to jedno z nielicznych tak starannie opracowanych pod względem teoretycznym i psychometrycznym narzędzi do oceny zachowania opiekunów w interakcjach z niemowlętami i małymi dziećmi.

\subsubsection{Interakcje diadyczne.}

2.3.2.2.1. Procedura kamiennej twarzy i fazy monadyczne. W procedurze kamiennej twarzy (Still Face Procedure) obserwuje się interakcje niemowlę-rodzic twarzą w twarz, bez użycia zabawek. Podczas gdy niemowlę siedzi w foteliku lub krzesełku, rodzic ma za zadanie w pierwszej fazie procedury nawiązać i podtrzymywać interakcję w naturalny dla siebie sposób, następnie zaprzestać reagowania na komunikaty dziecka i utrzymywać niezmienny („kamienny”) wyraz twarzy, a w ostatniej fazie powrócić do zwykłego zachowania (Cohn, Tronick, 1983). Chociaż sytuacja, kiedy rodzic przestaje reagować na sygnały i będąc twarzą w twarz z dzieckiem utrzymuje kamienny wyraz twarzy, jest poważnym stresorem dla dziecka, procedura ta była i nadal jest szeroko wykorzystywana w badaniach (zob. przeglądy w: Adamson, Frick, 2003 oraz Mesman, van IJzendoorn, Bakermans-Kranenburg, 2009). 
Cohn i Tronick (1983) kodowali nagrania podzielone na 5-sekundowe interwały i oceniali „stany” dziecka: patrzenie w bok, protest, czujność, monitorowanie i stan pozytywny. Szczegółowe kategorie, które były podstawą kodowania procedury pochodzą z systemu do oceny "faz monadycznych” (monadic phases; Cohn, Tronick, 1987; Tronick, Cohn, 1987; zob. też: Feldman, 2003). Jest to system mikroanalityczny, w którym wskaźniki behawioralne (kierunek spojrzenia, orientacja ciała, mimiczna ekspresja emocji itd.) składają się na „konfiguracje afektywne” (Feldman, 2003, s. 8), których natężenie jest oceniane.

W różnych badaniach wykorzystujących procedurę kamiennej twarzy interakcje kodowano również za pomocą innych systemów. Na przykład Field i współpracownicy (Field, Vega-Lahr, Scafidi, Goldstein, 1986) kodowali specyficzne zachowania dziecka (uśmiech, wokalizacje, aktywność ruchowa) i matki (uśmiech, wyolbrzymiona ekspresja mimiczna, wokalizacje). Zgodność sędziów kompetentnych w ocenie zachowań uczestników była wysoka (współczynnik korelacji od 0,81 do 0,93 dla ocen zachowania dziecka i 0,89 do 0,97 dla ocen zachowania matki). Yirmiya i in. (2006) zaadaptowali istniejące systemy, aby kodować kierunek spojrzenia i ekspresję emocjonalną niemowlęcia w 10-sekundowych interwałach. Zgodność sędziów kompetentnych była wysoka - kappa od 0,89. Natomiast Beebe i Gerstman (1984) kodowali klatka po klatce takie szczegóły, jak stopień rozwarcia ust i orientację głowy dziecka w trzech płaszczyznach, które wraz z innymi wskaźnikami składały się na miarę zaangażowania. Zgodność sędziów kompetentnych w tym badaniu była bardzo wysoka i bardzo wysoka (88\% dla stopnia ekspresji mimicznej i 95\% dla ogólnej zgodności co do tego, czy dane zachowanie wystąpiło).

2.3.2.2.2. Kodowanie stanów wspólnego zaangażowania. Bakeman i Adamson (1984; Adamson, Bakeman, Deckner, 2004; Adamson, Bakeman, Deckner, Nelson, 2012) opracowali systemy kodowania stanów wspólnego zaangażowania (joint engagement states), który skupia się na epizodach wspólnego działania dziecka i rodzica. Starsza wersja systemu została wykorzystana w badaniu porównującym interakcje matka-dziecko i dzieckodziecko (w wieku 6-15 miesięcy) i obejmowała sześć poziomów zaangażowania: brak zaangażowania (unengaged), przyglądanie się (onlooking), zaangażowanie - osoby (persons), zaangażowanie - przedmioty (objects), bierne wspólne zaangażowanie (passive joint engagement) oraz aktywne wspólne zaangażowanie (active joint engagement; Bakeman, Adamson, 
1984). Druga wersja, dla dzieci w wieku 8-30 miesięcy, oprócz wymienionych sześciu kategorii zawierała kolejnych pięć, które dotyczą zaangażowania obejmującego symbole: tylko symbol, osobę i symbol, przedmiot i symbol, zaangażowanie obejmujące symbol wspierane przez matkę oraz skoordynowane wspólne zaangażowanie obejmujące symbol (Adamson i in., 2004).

Materiałem obserwacyjnym, który zakodowano z użyciem tego systemu, była ustrukturyzowane sytuacja zabawowa - protokół zabawy komunikacyjnej (Communication Play Protocol), która ma stwarzać różnego rodzaju „konteksty komunikacyjne” (Adamson i in., 2004). Interakcje kodowano na podstawie nagrań, oglądając je w zwykłym tempie i spowalniając, aby precyzyjnie oznaczyć te momenty, kiedy kończył się jeden i zaczynał inny stan zaangażowania. Każde nagranie było kodowane przez parę wspólnie pracujących sędziów kompetentnych.

Ostatnia, najbardziej rozbudowana wersja systemu kodowania została opracowana do badania rozwoju typowego, a także dla dzieci z zaburzeniami ze spektrum autyzmu i z zespołem Downa. W odniesieniu do dziecka koduje się zaangażowanie (ogólne zaangażowanie, wspólne wspierane zaangażowanie, skoordynowane wspólne zaangażowanie i skoordynowane wspólne zaangażowanie obejmujące symbol) oraz inicjowanie i odpowiadanie na komunikaty, poziom mowy czynnej, jakość wzorców zachowania $i$ afekt. U rodzica koduje się nadawanie struktury, uwypuklanie symboli, podążanie za uwagą dziecka i afekt. Natomiast w odniesieniu do diady ocenia się rozwijanie, podtrzymywanie i zakres wspólnego tematu oraz płynność i spójność konwersacji (Adamson i in., 2012). Ta wersja systemu również została wykorzystana do oceny interakcji w ramach protokołu zabawy komunikacyjnej, jednak sędziowie kodowali w parach tylko stan zaangażowania dziecka, natomiast pozostałe kategorie sędziowie kodowali indywidualnie. Opisany system jest użyteczny ze względu na możliwość analizowania dynamiki zaangażowania dziecka w interakcję, rozwój funkcji symbolicznej i tych zachowań dziecka, rodzica i diady, które są szczególnie ważne z punktu widzenia rozwoju języka dziecka. Zgodność sędziów kompetentnych była dobra do wysokiej (kappa od 0,74 do 0,97).

2.3.2.2.3. Skale oceny globalnej. Skale oceny globalnej (Global Rating Scales; Gaffan i in., 2010; Murray i in., 1996) są przykładem miary, która łączy ogólną ocenę jakości interakcji z oceną specyficznych zachowań i ich współwystępowania lub następowania po sobie. Kontekstem interakcji jest 
zabawa niemowlęcia z matką twarzą w twarz. Pierwszy opis systemu zawarto $\mathrm{w}$ raporcie $\mathrm{z}$ badania dotyczącego jakości interakcji 2-miesięczne niemowlę-matka z objawami depresji poporodowej (Murray i in., 1996). W systemie tym na poziomie ogólnym u matki ocenia wrażliwość oraz intruzywność, a u niemowlęcia aktywność i zaangażowanie oraz dystres. Na poziomie specyficznych zachowań koduje się u matki potwierdzanie (empatyczne reakcje) i negacje (zaprzeczanie, reakcje niespójne z zachowaniem lub ekspresją emocjonalną dziecka). Natomiast specyficznymi zachowaniami kodowanymi u dziecka są pozytywne oraz negatywne ekspresje emocjonalne i nagłe przerywanie aktywności. Stwierdzono, że zgodność sędziów kompetentnych w ocenie tymi skalami jest wysoka - współczynniki korelacji wewnątrzklasowej od 0,82 do 0,97 (Murray i in., 1996).

2.3.2.2.4. System do kodowania interakcji diadycznych rodzic-dziecko. System do kodowania interakcji diadycznych rodzic-dziecko (Dyadic ParentChild Interaction Coding System; Eyberg, Nelson, Duke, Boggs, 2004; Nelson, Olsen, 2018) to narzędzie skoncentrowane na komunikatach werbalnych rodzica i dziecka oraz wokalizacjach dziecka, $\mathrm{z}$ dodatkowym uwzględnieniem dotyku. Kategoria komunikatów zawiera szereg rodzajów wypowiedzi (np. pochwała, polecenie, pytanie), a dotyk dzieli się na pozytywny i negatywny. Ocenie podlegają interakcje zabawowe różnego rodzaju: zabawa kierowana przez dziecko, zabawa kierowana przez rodzica oraz wspólne sprzątanie po zabawie. Pierwsza wersja systemu powstała jako narzędzie do oceny zmian w toku terapii interakcji rodzic-dziecko (McNeil, Eyberg, Hembree Eisenstadt, Newcomb, Funderburk, 1991). Narzędzie w obecnej (trzeciej) wersji posiada ustalone podstawowe właściwości psychometryczne i jest w całości dostępne wraz ze szczegółowym podręcznikiem w wersji elektronicznej (Eyberg $\mathrm{i}$ in., 2004).

2.3.2.2.5. Kodowanie mikroanalityczne. Beatrice Beebe (2006) podkreśla znaczenie kodowania zachowań o krótkim czasie trwania i niewidocznych gołym okiem, obejmujących w szczególności spojrzenia, orientację głowy, wyraz twarzy i wokalizacje niemowlęcia. W badaniu jej współpracowników (Koulomzin i in., 2002) mikroanalitycznie kodowano kierunek spojrzenia (na matkę versus na coś innego), mimiczne ekspresje emocji (w tym szereg zmian związanych z ekspresją mimiczną w różnych częściach twarzy: gładkie versus zmarszczone czoło, uniesione policzki, różne stopnie rozwarcia ust), orientację głowy (kąt odchylenia od linii środkowej, 
na której znajdowała się twarz matki), dotyk i poruszanie lub dotykanie ustami. Ten szczegółowy schemat kodowania okazał się trafny, ponieważ analizowane zachowania u niemowląt $\mathrm{w}$ wieku 4 miesięcy były predyktorami jakości przywiązania (wzorzec ufny versus lękowy) w wieku 12 miesięcy (Koulomzin i in., 2002). Zgodność sędziów kompetentnych w tym badaniu była umiarkowana do wysokiej (kappa od 0,78 do 0,97, w zależności od kodowanego zachowania).

\subsubsection{Interakcje triadyczne.}

2.3.2.3.1. Lozańska zabawa trialogowa. Prawdopodobnie najbardziej znaną procedurą do badania interakcji w triadzie matka-ojciec-niemowlę jest Lozańska zabawa trialogowa (Lausanne Trilogue Play, LTP; Fivaz-Depeursinge, 2008; Fivaz-Depeursinge, Corboz-Warnery, 1999; Fivaz-Depeursinge, Favez, Lavanchy, De Noni, Frascarolo, 2005; McHale, Fivaz-Depeursinge, 1999). „Trialog” w nazwie procedury to neologizm utworzony ze słowa dialog. Wskazuje ono na triadyczny charakter zabawy, w przeciwieństwie do diadycznego. Teoretyczne ramy LTP stanowi systemowe rozumienie rodziny.

Podczas zabawy uczestnicy siedzą w taki sposób, że tworzą trójkąt, w którym każdy widzi każdego i może z łatwością nawiązać kontakt wzrokowy. W wersji podstawowej procedura składa się z epizodów: (1) zabawy w diadzie (jeden rodzic jest aktywny, drugi jest obecny, ale tylko obserwuje), (2) zabawy w diadzie (zamiana ról między rodzicami), (3) zabawy w triadzie (oboje rodzice są aktywni) i (4) rozmowy rodziców ze sobą. Natomiast w wersji z epizodami kamiennej twarzy procedura rozpoczyna się od zabawy $\mathrm{w}$ triadzie, następnie jeden $\mathrm{z}$ rodziców przyjmuje niezmienny („kamienny") wyraz twarzy, a drugi pozostaje aktywny, później następuje zamiana ról między rodzicami, a w ostatniej fazie oboje rodziców znów aktywnie uczestniczy w zabawie. Jest to modyfikacja klasycznej procedury kamiennej twarzy (Cohn, Tronick, 1983). Dzięki uwzględnieniu zróżnicowanych następujących po sobie epizodów, LTP pozwala obserwować dynamikę interakcji przy zmieniającym się poziomie zaangażowania poszczególnych uczestników. Ocena materiału obserwacyjnego może odbywać się na poziomie mikroanalitycznym bądź makroanalitycznym i może znaleźć zastosowanie zarówno w badaniach naukowych, jak i w praktyce klinicznej (McHale, Favez, Fivaz-Depeursinge, 2018).

Autorzy opracowali globalny (makroanalityczny) system kodowania LTP obejmujący ocenę zachowań (niewerbalnych zachowań komunikacyjnych i zabawy) pod kątem ich adekwatności (Carneiro, Corboz-Warnery, 
Fivaz-Depeursinge, 2006; Fivaz-Depeursinge, Corboz-Warnery, Carneiro, Wasem, 2002). Ponadto w jednym $\mathrm{z}$ badań Fivaz-Depeursinge i in. (2005) kodowali na poziomie mikroanalitycznym spojrzenia, konfiguracje afektywne i inicjacje triangulacyjne. Innym narzędziem również opracowanym z myślą o ocenie interakcji w ramach LTP są skale do oceny przymierza rodzinnego (Family Alliance Assessment Scales; Favez, Scaiola, Tissot, Darwiche, Frascarolo, 2011; Lavanchy Scaiola, Favez, Tissot, Frascarolo, 2009).

Powstał również system kodowania interakcji dziecka i rodziców (Child and Parents' Interaction Coding System; Hedenbro, Lidén, 2002; Hedenbro, Rydelius, 2019), który pozwala dokonywać jakościowych i ilościowych ocen skoncentrowanych na zachowaniach komunikacyjnych rodziców i dziecka. System został szczegółowo opisany i udostępniony w pracy Hedenbro i Lidén (2002)

2.3.2.3.2. Triadyczne i diadyczne koło interakcyjne. Triadyczne i diadyczne koło interakcyjne (Kmita, 2013, 2018; Kmita, Kiepura, Majos, 2014) to procedura do badania interakcji rodziców z dzieckiem i osobą obcą. Istnieją dwie wersje procedury - dla niemowląt 6- i 12-miesięcznych. Procedura przypomina LTP, ponieważ oprócz zabawy swobodnej w triadzie zawiera epizody zabawy diadycznej, a także epizod rozmowy między rodzicami (z osobą obcą). Jednak w triadycznym i diadycznym kole interakcyjnym podczas zabawy w diadzie dziecko-rodzic, drugi rodzic jest nieobecny. Ponadto procedura obejmuje epizody z osobą obcą, kiedy jest ona bierna, następnie rozmawia $\mathrm{z}$ rodzicami i wreszcie, kiedy próbuje nawiązać kontakt z dzieckiem. Osoba obca wprowadza również nowy element do zabawy ciekawą, skomplikowaną zabawkę, która wcześniej była schowana. W wersji dla dzieci 12-miesięcznych obecny jest również epizod bez rodziców (oboje na chwilę opuszczają pokój i dziecko zostaje samo). Procedurze obserwacyjnej towarzyszy bardzo szczegółowy mikroanalityczny system kodowania zachowań wszystkich uczestników interakcji. Koduje się m.in. proksemikę, afekt, uwagę wzrokową, mowę, wokalizacje i behawioralne strategie samoregulacji dziecka. Każda nadrzędna kategoria zachowań zawiera szereg podkategorii, a część $\mathrm{z}$ nich dodatkowo specyfikację, do kogo lub na co skierowane jest dane zachowanie. Analiza danych może obejmować częstość i czas trwania poszczególnych zachowań, ich współwystępowanie i następowanie po sobie oraz powstające sekwencje lub wiązki, które tworzą zachowania na poziomie makroanalitycznym (np. następujące po sobie skupianie wzroku to na przedmiocie, to na twarzy osoby może tworzyć epizod podzielania 
uwagi). Zgodność sędziów kompetentnych w ocenie nagrań za pomocą tego systemu wyniosła kappa 0,73 (Kmita, 2013).

2.3.2.3.3. Kodowanie zachowań interakcyjnych. Narzędzie Feldman $(1998,2007 b, 2010)$ do kodowania zachowań interakcyjnych (Coding Interactive Behavior) jest systemem oceny globalnej. Składa się z części dla triad i diad. Możliwa jest zatem ocena systemu dziecko-matka-ojciec jako całości, a także diad dziecko-rodzic w jego obrębie. Podskale dla diad dotyczą wrażliwości macierzyńskiej (spojrzenie, afekt, wokalizacje, dotyk, przewidywalność, adaptacja do zachowań dziecka), intruzywności, zaangażowania dziecka i wzajemności diadycznej. Natomiast pozycje dotyczące triad składają się na dwa czynniki: spójność rodziny i sztywność rodziny (Feldman, Masalha, Nadam, 2001). Obserwowane zachowania ocenia się na skali od 1 do 5. Narzędzie posiada wersje dla różnych grup wiekowych, od niemowląt do nastolatków. System ten był szeroko stosowany w badaniach i ma dobre właściwości psychometryczne (Feldman, 2010).

2.3.2.4. Interakcje czterech lub więcej osób. Badacz lub klinicysta, który myśli o rodzinie jako o systemie może być zainteresowany obserwacją interakcji rodzin z dwojgiem lub więcej dziećmi. Do tego celu opracowano Lozańską zabawę rodzinną (Lausanne Family Play; Frascarolo, Tissot, Favez, 2011). Podczas zabawy rodzina siedzi przy stole i ma za zadanie „bawić się jak zwykle” (Frascarolo i in., 2011, s. 2) dostarczonymi zabawkami, ale poziom zaangażowania uczestników jest narzucony, tak jak w LTP. Najpierw jeden rodzic bawi się z dziećmi, a drugi tylko obserwuje, następnie zamieniają się rolami, później wszyscy uczestnicy bawią się razem, a na końcu rodzice rozmawiają ze sobą. Jak podają autorzy, procedura ta jest odpowiednia dla rodzin, w których najmłodsze dziecko jest w stanie siedzieć w wysokim krzesełku, a najstarsze ma 12-13 lat. Ocenia się: partycypację, organizację ról, wspólne skupienie, ciepło rodzinne, błędy komunikacyjne i ich naprawianie oraz zaangażowanie dzieci. Możliwa jest również ocena za pomocą zmodyfikowanej wersji Skal do oceny przymierza rodzinnego (Favez i in., 2011; Lavanchy Scaiola i in., 2009).

Drugim narzędziem również opracowanym przez badaczy z Lozanny jest Zabawa w piknik (The PicNic Game; Favez, Frascarolo, Grimard, 2016; Frascarolo i in., 2011). Rodzina $z$ dziećmi w dowolnym wieku ma za zadanie pobawić się na niby w piknik, przy czym każdy członek rodziny ma odgrywać siebie. Autorzy proponują, aby analizę materiału obserwacyjnego 
rozpocząć od oceny klinicznej (odpowiadając na pytania dotyczące partycypacji, przywództwa, struktury zadania itd.), a następnie wykorzystać opracowany specjalnie do analizy tej sytuacji schemat oceny (Favez i in., 2016).

Niestety nie określono właściwości psychometrycznych tych schematów oceny interakcji.

\subsubsection{Narzędzia dla dzieci z rodzinnym ryzykiem wystąpie- nia zaburzeń ze spektrum autyzmu lub objawami autyzmu.}

2.3.2.5.1. Manchesterskie narzędzie do oceny jakości interakcji opiekun-dziecko. Narzędzie Manchester Assessment of Caregiver-Infant Interaction (MACI; Wan i in., 2012, 2013) zostało stworzone na potrzeby badań $\mathrm{z}$ udziałem dzieci obciążonych rodzinnym ryzykiem wystąpienia autyzmu (mających starsze rodzeństwo $\mathrm{z}$ diagnozą autyzmu). Jest to skala do globalnej oceny interakcji diadycznych dla niemowląt i małych dzieci w wieku od 5 do 15 miesięcy. Składa się w sumie z siedmiu podskal. Dwie z nich dotyczą opiekuna: wrażliwa responsywność (dostrzeganie zachowań dziecka i odpowiadanie na nie w sposób spójny i adekwatny, zaspokajanie potrzeb bieżących i rozwojowych, zaangażowanie, wspieranie, nadawanie struktury aktywności dziecka) i niedyrektywność (akceptowanie aktywności dziecka, koncentracja na pomysłach dziecka i zachęcanie do ich realizacji, kierowanie do dziecka pozytywnych, wspierających komentarzy, niewydawanie poleceń). Trzy dotyczą dziecka: uważność na rodzica (czas trwania kontaktu wzrokowego $\mathrm{z}$ rodzicem, zainteresowanie rodzicem, jego aktywnością i przedmiotami, którymi się zajmuje, stosowanie odniesienia społecznego), pozytywny afekt (wysoki poziom pozytywnego afektu, niski poziom negatywnego afektu) i żwawość (poziom spontanicznej aktywności dziecka). Pozostałe dwie koncentrują się na diadzie. Są to wzajemność (wzajemne dostrojenie, podzielanie doświadczenia, w tym podzielanie uwagi, wspólna zabawa, płynność interakcji) i intensywność zaangażowania (nasilenie pozytywnego afektu: ekscytacji, zainteresowania, poziom dostrojenia). Oceny dokonuje się na skali porządkowej od 1 do 7 . Narzędzie posiada normy dla grupy brytyjskiej. W pierwszym badaniu (Wan i in., 2012) zgodność sędziów kompetentnych była umiarkowana do wysokiej, w zależności od skali (współczynniki korelacji wewnątrzklasowej przyjmowały wartość od 0,58 do 0,82). W kolejnym badaniu ustalono również inne właściwości psychometryczne narzędzia (Wan, Brooks, Green, Abel, Elmadih, 2017). 
2.3.2.5.2. Miara komunikacji diadycznej w autyzmie. Miara komunikacji diadycznej w autyzmie (Dyadic Communication Measure for Autism; Aldred, Green, Adams, 2004) została opracowana do oceny skuteczności interwencji terapeutycznej skoncentrowanej na komunikowaniu się dla dzieci z zaburzeniami ze spektrum autyzmu w wieku 2-6 lat (Green i in., 2010; Pickles i in., 2016). Kodowanie dotyczy tych aspektów zachowania, które są szczególnie istotne w rozwoju języka dziecka i stanowią trudność dla osób z autyzmem. Ocenie podlegają: (1) jakość aktów komunikacyjnych rodzica (synchroniczne, tu w znaczeniu niedyrektywne - komentarze, opisy zachowania dziecka, przytakiwanie, potwierdzanie, versus niesynchroniczne, czyli dyrektywne - polecenia, pytania, próby zmiany zachowania dziecka), (2) zachowania komunikacyjne dziecka (inicjowanie i odpowiadanie na komunikaty rodzica) oraz (3) podzielanie uwagi w diadzie. Zachowaniom komunikacyjnym dziecka i rodzica można również przypisać dodatkowe kody dookreślające ich charakter (np. inicjowanie przez dziecko: prośba, ukierunkowywanie uwagi; odpowiedź dziecka: komentarz, negacja, przyjęcie). Koduje się zarówno zachowania werbalne, jak i niewerbalne. Oceniając interakcje, można obliczyć np. proporcje różnych rodzajów aktów komunikacyjnych czy czas trwania epizodów podzielania uwagi. Narzędzie to zostało opracowane $\mathrm{z}$ myślą o kodowaniu w czasie rzeczywistym, dlatego dotyczy zachowań dostrzegalnych „gołym okiem”, jednak znacznym ułatwieniem w późniejszej ocenie materiału jest kodowanie nagrań za pomoc odpowiedniego oprogramowania. Zgodność sędziów kompetentnych oceniono jako dobrą i wysoką (kappa od 0,72 do 1,00; Aldred i in., 2004).

2.3.2.5.3. Ocena radości i zabawy. Skala do oceny radości i zabawy (Joy and Fun Assessment; McConachie, Randle, Hammal, Le Couteur, 2005; Parr, Gray, Wigham, McConachie, Le Couteur, 2015) została opracowana do oceny zmiany zachowania rodzica $\mathrm{w}$ wyniku interwencji mającej na celu poprawienie jakości zabawy w diadzie rodzic-dziecko z ASD, w szczególności zwiększenie przyjemności płynącej z tej zabawy. Interwencja jest przeznaczona dla rodziców tych małych dzieci, u których stwierdzono opóźnienie rozwoju mowy i objawy zaburzeń ze spektrum autyzmu. Kodowane są zachowania, które rodzic ćwiczył w ramach interwencji, mające na celu ułatwianie zabawowych interakcji z dzieckiem, m.in. używanie uproszczonego języka, chwalenie czy uśmiech i śmiech. Zachowania interakcyjne dziecka nie są kodowane. Zgodność sędziów kompetentnych w kodowaniu zachowań rodzica oceniono jako wysoką (Parr i in., 2015). 
2.3.2.5.4. Skala do oceny interakcji społecznych. Skala do oceny interakcji społecznych (Social Interaction Rating Scale; Ruble, McDuffie, King, Lorenz, 2008) również jest narzędziem opracowanym do oceny skuteczności interwencji dla rodziców dzieci z ASD. Narzędzie składa się z sześciu pozycji ocenianych na skali od 1 do 5, są to: spójność, dyrektywność, inicjacje skierowane do dziecka, poruszanie się razem z dzieckiem, afekt oraz podtrzymywanie interakcji z dzieckiem. Wyniki można zsumować, uzyskując ogólną ocenę responsywności opiekuna. Zgodność sędziów kompetentnych oceniono jako wysoką. W pracy Ruble i in. (2008) znajduje się całość narzędzia wraz ze wskazówkami dla oceniających.

Podsumowując, schematy oceny interakcji są zróżnicowane i mają duży potencjał, jeśli chodzi o ich zastosowanie w badaniach. Ich zastosowanie wymaga jednak ostrożności, ponieważ, poza nielicznymi wyjątkami, są to narzędzia niewystandaryzowane nawet dla oryginalnych prób badawczych i większość z nich nie ma ustalonych właściwości psychometrycznych innych niż tylko zgodność sędziów kompetentnych.

2.3.3. Automatyczne zbieranie danych. Na koniec należy nadmienić, że istnieją narzędzia umożliwiające częściową automatyzację procesu zbierania i kodowania danych. Dotyczy to w szczególności wykrywania kierunku spojrzenia, mimicznej ekspresji emocji, ruchów ciała i mowy.

Analiza zachowań uwagowych (np. czasu patrzenia na bodźce, częstości przenoszenia wzroku, a na poziomie makroanalitycznym uwspólniania i podzielania uwagi) jest częstym elementem badań nad rozwojem w dzieciństwie i w badaniach interakcji w ogóle. Jednak kodowanie uwagi wzrokowej przez sędziów kompetentnych jest czasochłonne oraz obarczone sporym błędem. Wynika to $\mathrm{z}$ faktu, że w polu widzenia osoby znajdować się może $\mathrm{w}$ danym momencie wiele bodźców i ustalenie, na który z nich w istocie patrzy osoba, może sprawiać trudności. Zadanie jest łatwiejsze, kiedy koduje się interakcje twarzą w twarz $\mathrm{z}$ dzieckiem siedzącym w foteliku, w specjalnie przygotowanym do tego celu pokoju badawczym. Jednak im bardziej otoczenie badanych jest zbliżone do naturalnego, im starsze dziecko i im więcej swobody mają osoby badane w wyborze aktywności, tym trudniejsze jest rzetelne kodowanie uwagi wzrokowej. Pewnym ułatwieniem w takiej sytuacji jest stosowanie przenośnych systemów do eye-trackingu (okulografii; np. Abney, Smith, Yu, 2017; Pereira, Shen, Smith, Yu, 2009; Venuprasad 
i in., 2019). Umieszczenie opaski z detektorem ruchu oczu na głowach osób badanych pozwala precyzyjnie ustalać, na co patrzą. Wiąże się jednak z różnymi niedogodnościami. Po pierwsze, dziecko musi tolerować urządzenie na głowie, po drugie, ze względów technicznych obszar, po którym osoby badane mogą się poruszać, jest ograniczony. Okulografia jest zwykle wykorzystywana w laboratorium, ale nie w obserwacji w warunkach domowych.

$\mathrm{W}$ analizie epizodów interakcyjnych twarzą $\mathrm{w}$ twarz prawie zawsze badacze są zainteresowani mimiczną ekspresją emocji uczestników. Ustalenie, jaką emocję wyraża osoba, szczególnie na poziomie mikroanalitycznym (przy kodowaniu ciągłym, klatka po klatce), nie zawsze jest łatwe. Zmiany w ekspresji mimicznej są z jednej strony dynamiczne, a z drugiej - mogą być bardzo subtelne. Aby ułatwić identyfikację wyrażanych emocji, można zastosować oprogramowanie do ich detekcji. Systemy specjalnie opracowane dla niemowląt i małych dzieci dopiero są rozwijane (Maroulis, Spink, Theuws, Oster, Buitelaar, 2017), natomiast istnieje wiele algorytmów dla detekcji mimicznych ekspresji osób dorosłych (np. Matsugu, Mori, Mitari, Kaneda, 2003; Stöckli, Schulte-Mecklenbeck, Borer, Samson, 2018), także pozwalających śledzić zmiany w ekspresji (ruch twarzy; Lien, Kanade, Cohn, Li, 2000; Polikovsky, Kameda, Ohta, 2013; Valstar, Pantic, 2006). Zastosowanie tych programów wymaga nagrania obrazu w wysokiej jakości, przedstawiającego twarz z przodu.

Na uwagę zasługują również narzędzia do automatycznej detekcji i analizy ruchu (np. Brenger, Mittelberg, 2015; Lebowitz, Shic, Campbell, MacLeod, Silverman, 2015; López Pérez i in., 2017; Yu, Smith, Pereira, 2008) oraz także mowy (Greenwood, Schnitz, Irvin, Tsai, Carta, 2018; Mahdhaoui i in., 2011; Oller i in., 2010).

Wszystkie wymienione tu narzędzia bywają zawodne; konieczna jest weryfikacja danych przez człowieka. Mogą one jednak zwiększać efektywność i rzetelność analiz, w szczególności na poziomie mikroanalitycznym. Ogólna ocena zachowania wciąż pozostaje domeną wyszkolonych sędziów kompetentnych. 

czEşé 2 


\section{ROzWój KOMPETENCJI INTERAKCYJNYCH W PIERWSZYM ROKU ŻYCIA}

Niemowlęta od urodzenia są w stanie aktywnie kształtować przebieg interakcji z opiekunem. W szczególności potrafią odpowiadać na zachowania drugiej osoby i uczestniczyć w naprzemiennej komunikacji (Trevarthen, Aitken, 2001). Rozwój zachowań interakcyjnych w diadzie niemowlę-rodzic stanowi podstawę dalszego rozwoju komunikacji społecznej dziecka (Legerstee, 2009). W tabeli 3 Czytelnik znajdzie podsumowanie informacji na temat rozwoju kompetencji interakcyjnych niemowlęcia.

\section{Tabela 3}

Podsumowanie informacji na temat rozwoju kompetencji interakcyjnych niemowlęcia

\begin{tabular}{llll}
\hline Wiek & $\begin{array}{c}\text { Patrzenie } \\
\text { i uwaga } \\
\text { wzrokowa }\end{array}$ & \multicolumn{1}{c}{$\begin{array}{c}\text { Struktura } \\
\text { interakcji }\end{array}$} & $\begin{array}{c}\text { Percepcja } \\
\text { i ekspresja } \\
\text { emocji }\end{array}$ \\
\hline Od urodzenia & $\begin{array}{l}\text { Patrzenie na } \\
\text { twarze i na } \\
\text { wyraziste } \\
\text { percepcyjnie } \\
\text { przedmioty }\end{array}$ & Dziecko-dorosły & $\begin{array}{l}\text { Wyrażanie } \\
\text { pozytywnych } \\
\text { i negatywnych } \\
\text { stanów }\end{array}$ \\
& & $\begin{array}{l}\text { Rozróżnianie } \\
\text { newnętrzna } \\
\text { kontrola uwagi }\end{array}$ & $\begin{array}{l}\text { podstawowych } \\
\text { emocji }\end{array}$ \\
\hline
\end{tabular}


Ciąg dalszy tabeli z poprzedniej strony.

\begin{tabular}{|c|c|c|c|}
\hline \multirow[t]{2}{*}{ 3-4 miesiące } & \multicolumn{2}{|l|}{$\begin{array}{l}\text { Patrzenie } \\
\text { na osoby } \\
\text { i przedmioty }\end{array}$} & \multirow{2}{*}{$\begin{array}{l}\text { Adresowanie } \\
\text { wyrażanych } \\
\text { emocji do } \\
\text { opiekunów } \\
\text { dzięki łączeniu } \\
\text { ekspresji emocji } \\
\text { z kierowaniem na } \\
\text { nich spojrzenia }\end{array}$} \\
\hline & \multicolumn{2}{|l|}{$\begin{array}{l}\text { Wyłanianie się } \\
\text { wewnętrznej } \\
\text { kontroli uwagi }\end{array}$} & \\
\hline \multirow[t]{4}{*}{ Około 6 miesięcy } & \multirow{4}{*}{$\begin{array}{l}\text { Dalszy rozwój } \\
\text { wewnętrznej } \\
\text { kontroli uwagi }\end{array}$} & J.w. oraz & \multirow{4}{*}{$\begin{array}{l}\text { Wzrost } \\
\text { wrażliwości } \\
\text { na mimiczną } \\
\text { ekspresję strachu }\end{array}$} \\
\hline & & $\begin{array}{l}\text { Dziecko-dorosły- } \\
\text { dorosły }\end{array}$ & \\
\hline & & $\begin{array}{l}\text { Dziecko- } \\
\text { przedmiot }\end{array}$ & \\
\hline & & $\begin{array}{l}\text { Dziecko- } \\
\text { przedmiot } \\
\text { trzymany przez } \\
\text { dorosłego }\end{array}$ & \\
\hline \multirow[t]{5}{*}{ Od 9-12 miesięcy } & \multirow{2}{*}{$\begin{array}{l}\text { Uwaga } \\
\text { wykonawcza }\end{array}$} & J.w. oraz & \multirow{3}{*}{$\begin{array}{l}\text { Rozróżnianie } \\
\text { wszystkich } \\
\text { podstawowych } \\
\text { ekspresji emocji }\end{array}$} \\
\hline & & Dziecko-dorosły- & \\
\hline & Podzielanie uwagi & przedmiot & \\
\hline & \multirow[t]{2}{*}{$\begin{array}{l}\text { Odniesienie } \\
\text { społeczne }\end{array}$} & $\begin{array}{l}\text { Dziecko- } \\
\text { dorosły-dorosły- } \\
\text { przedmiot }\end{array}$ & \multirow{2}{*}{$\begin{array}{l}\text { Regulacja } \\
\text { zachowania } \\
\text { na podstawie } \\
\text { informacji } \\
\text { o uwadze } \\
\text { i ekspresji } \\
\text { emocjonalnej } \\
\text { drugiej osoby }\end{array}$} \\
\hline & & Dziecko-dziecko & \\
\hline
\end{tabular}

\subsection{Interakcje twarzą w twarz}

Struktura epizodów interakcyjnych w pierwszym okresie życia bazuje na wymianach osoba-osoba, a jedną z podstawowych ich form są interakcje twarzą w twarz. Noworodki mają tendencję do kierowania spojrzenia (orientowania się) na twarze (Farroni i in., 2005) i stopniowo rozwijają się u nich wyspecjalizowane mechanizmy przetwarzania informacji o twarzach (Johnson, 2005). Specjalizacja oznacza tu nabywanie biegłości w przetwarzaniu informacji o danej klasie bodźców: ich rozróżnianiu, zapamiętywaniu i rozumieniu sygnałów, które komunikują. Zachodzi ona dzięki wrodzonym 
mechanizmom kierowania uwagi ${ }^{11}$ na twarze i uczeniu się (Morton, Johnson, 1991). To uczenie się przebiega właśnie w ramach interakcji z innymi osobami.

Kontakt wzrokowy odgrywa szczególną rolę w interakcjach społecznych na przestrzeni całego życia człowieka (np. Baron-Cohen, Wheelwright, Jolliffe, 1997; Conty, George, Hietanen, 2016; Farroni, Johnson, Csibra, 2004; Hietanen, 2018; Hoehl, Wahl, Pauen, 2013; MacDonald, 2009; Robson, 1967; Schilbach, 2015; Senju, Johnson, 2009a, 2009b). Podczas interakcji twarzą w twarz, głowy dziecka i rodzica znajdują się na tym samym poziomie, co umożliwia im nawiązywanie kontaktu wzrokowego. Z punktu widzenia dziecka podczas takiej interakcji spojrzenie opiekuna skierowane na wprost oznacza, że patrzy on na dziecko. Doświadczenie to odgrywa ważną rolę w rozwoju poczucia siebie jako odrębnej osoby (por. Reddy, 2003). Kontakt wzrokowy służy komunikowaniu się, budowaniu bliskości oraz uczeniu się (Csibra, Gergely, 2009; Heyes, 2016).

Noworodki widzą nieostro, szczególnie w centralnej części pola widzenia. Lepiej widzą zewnętrzne niż wewnętrzne części bodźców, które znajdują się na wprost (Johnson, 1990). Z każdym kolejnym miesiącem wzrok niemowlęcia ulega poprawie, aż około 6. miesiąca życia ostrość widzenia staje się taka sama jak u dorosłych (Courage, Adams, 1990; Sokol, 1978). Aby dziecko w pierwszych miesiącach życia mogło względnie ostro widzieć twarz dorosłego, partnerzy interakcyjni muszą się znajdować w niewielkiej odległości. To opiekun jest odpowiedzialny za takie ułożenie dziecka, aby możliwy był kontakt twarzą w twarz i by dziecko mogło jak najlepiej widzieć twarz partnera interakcji. Ogólnie rzecz biorąc, w pierwszym okresie życia uwaga niemowlęcia ma charakter egzogenny (jest zależna od bodźców zewnętrznych; Colombo, 2001), dlatego to dorosły w znacznej mierze decyduje o tym, co znajdzie się w polu widzenia dziecka - czy będzie to jego twarz, czy inny bodziec.

Interakcje twarzą w twarz składają się z epizodów utrzymywania kontaktu wzrokowego oraz przerw interakcyjnych. Są to momenty, kiedy jeden z uczestników wycofuje się z kontaktu wzrokowego i przekierowuje wzrok $\mathrm{w}$ inne miejsce. Takie sekwencje zachowań interakcyjnych są typowe w diadach niemowlę-rodzic w pierwszych miesiącach życia (Tronick, 1989).

11 Termin „uwaga” odnosi się do poziomu psychicznego (procesy uwagowe są wewnętrzne), natomiast „patrzenie” odnosi się do poziomu behawioralnego (obserwowalnego zachowania). 
Początkowo jednak epizody te są sterowane przez rodzica, ponieważ wymagają one od niemowlęcia pewnego poziomu dojrzałości uwagowej sieci orientacyjnej (Johnson, Posner, Rothbart, 1991; zob. również Nęcka, Orzechowski, Szymura, 2007). Dziecko musi bowiem najpierw wycofać uwagę $\mathrm{z}$ angażującego bodźca - twarzy, następnie przekierować uwagę na inny bodziec i skupić ją na nim (na poziomie behawioralnym: przenieść spojrzenie z twarzy na inny bodziec). Aby powrócić do kontaktu wzrokowego, musi wycofać uwagę z bodźca, przekierować ją i skupić na twarzy partnera. Nie są to banalne umiejętności - noworodki mają trudność z wycofywaniem uwagi z bodźca, na który patrzą (Johnson, 1990, 1994). Umiejętność ta pojawia się w wieku ok. 4 miesięcy, wraz z dojrzewaniem korowych mechanizmów kontroli uwagi (Atkinson, Braddick, 2012). Wtedy rolą opiekuna jest pozwolenie dziecku na wycofywanie się z kontaktu wzrokowego i cierpliwe czekanie, aż niemowlę znów skieruje wzrok w okolice jego oczu. Jest to niezwykle ważne, ponieważ kontakt wzrokowy jest silnym, pobudzającym bodźcem. Niemowlę potrzebuję więc okresów ograniczenia dopływu bodźców, aby mogło utrzymywać odpowiedni poziom pobudzenia.

Dzięki szybkiemu wzrostowi zdolności sprawowania kontroli nad własną uwagą w 1. roku życia (zob. Johnson, de Haan, 2018), niemowlę staje się coraz bardziej niezależne od działań opiekuna (i innych wpływów otoczenia). Jego zachowanie w interakcjach jest w coraz większym stopniu kontrolowane wewnętrznie.

Niemowlęta mają również tendencję do patrzenia na usta partnera interakcyjnego. Uczą się w ten sposób mowy, obserwując ruch ust partnera interakcji i słuchając towarzyszących mu, spójnych z tym ruchem, dźwięków (np. Hillairet de Boisferon, Tift, Minar, Lewkowicz, 2017; Hunnius, Geuze, 2004; Tsang, Atagi, Johnson, 2018). U typowo rozwijających się niemowląt w ciągu 1. roku życia istnieje pewien charakterystyczny wzorzec zmian w czasie patrzenia na oczy i usta. Lewkowicz i Hansen-Tift (2012) wykazali tę prawidłowość w swoim badaniu z udziałem dzieci wychowywanych w środowisku anglojęzycznym. Niemowlęta 4-miesięczne patrzyły głównie na oczy, a 6-miesięczne w przybliżeniu tak samo długo na oczy i usta. Następnie czas patrzenia na oczy spadał, a na usta wzrastał, tak że w wieku 8 i 10 miesięcy dominowało patrzenie na usta. W kolejnych dwóch miesiąca życia niemowlęta przez coraz dłuższy czas patrzyły na oczy, podążając ścieżką rozwojową, która prowadzi do typowej dla dorosłych tendencji do skupiania uwagi na oczach (Lewkowicz, Hansen-Tift, 2012). Inne badanie podłużne potwierdziło te wyniki: czas patrzenia na oczy wzrastał między 
9. i 12. miesiącem życia. Ponadto w wieku 6, 9 i 12 miesięcy niemowlęta patrzyły dłużej na usta osób, które mówiły, niż takich, które się tylko uśmiechały (Tenenbaum, Shah, Sobel, Malle, Morgan, 2013). Wyniki te pokazują, że tendencja do patrzenia na różne części twarzy zależy od wieku dziecka i zachowania partnera interakcji.

Ważnym aspektem interakcji twarzą w twarz jest towarzysząca im radość rodzica i dziecka. W kontakcie wzrokowym z dzieckiem rodzic, często zmęczony sprawowaniem opieki i innymi obowiązkami, może zobaczyć w dziecku osobę i partnera, a nie tylko odbiorcę czynności pielęgnacyjnych. Kiedy około 6. tygodnia życia pojawia się uśmiech społeczny (Messinger, Fogel, 2007), opiekun otrzymuje od dziecka czytelny, pozytywny komunikat afektywny, rodzaj nagrody za swój wysiłek ${ }^{\mathbf{1 2}}$. Ponadto w niedawnym badaniu podłużnym uzyskano następujący wynik: pozytywny afekt matki i dziecka w wieku 4 miesięcy podczas 2-minutowej interakcji twarzą w twarz był predyktorem rozwoju językowego dziecka w wieku 4,5 roku (Sheinkopf i in., 2017). Pozytywny afekt matki wiązał się również z wynikami dziecka w skali inteligencji w wieku 7 lat (zarówno w skali werbalnej, jak i wykonaniowej). Zatem podzielanie pozytywnych stanów emocjonalnych we wczesnych interakcjach $z$ opiekunem ma dalekosiężny wpływ na rozwój poznawczy dziecka.

W wieku 3 miesięcy niemowlę osiąga takie kompetencje uwagowe, tzn. zdolność do utrzymywania i przenoszenia uwagi, że jest wstanie uczestniczyć w interakcjach twarzą w twarz z trzema osobami, czyli interakcjach triadycznych ${ }^{13}$ (zob. Fivaz-Depeursinge, 2008; Senator, 2006).

Tendencja niemowlęcia do patrzenia na twarze jest ważnym mechanizmem rozwoju. Patrząc na twarz, dziecko może poznać drugą osobę oraz jej stosunek do dziecka i do otaczającego świata. Dzięki dynamicznemu wzrostowi biegłości w przetwarzaniu informacji o różnych bodźcach i kontroli uwagi, niemowlęta pod koniec 1. roku życia są w stanie uczestniczyć w złożonych formach komunikowania się, takich jak podzielanie uwagi i kierowanie do partnerów interakcji pierwszych słów (Butterworth, 2004; zob. niżej) oraz mogą uczyć się od innych osób (Bandura, 1977/2007). Zestawienie

12 W relacji matek pierwszy uśmiech społeczny u dziecka pojawia się wcześniej, niż wynika to z obserwacji przez osobę postronną (zob. Berger, Cunningham, 1986).

13 W literaturze termin „triadyczna” może również oznaczać interakcję diadyczną z wykorzystaniem przedmiotu. Jest to zatem interakcja osoba-osoba-przedmiot, w odróżnieniu od nadmienionej tu interakcji osoba-osoba-osoba. 
terminów odnoszących się do uwagi w interakcjach diadycznych znajduje się w tabeli 4.

Tabela 4

Uwaga wzrokowa w interakcjach diadycznych

\begin{tabular}{|c|c|c|}
\hline Termin & $\begin{array}{l}\text { Definicja i terminy } \\
\text { powiązane }\end{array}$ & $\begin{array}{l}\text { Odnośniki } \\
\text { bibliograficzne }\end{array}$ \\
\hline \multirow{3}{*}{$\begin{array}{l}\text { Uwaga wzajemna/ } \\
\text { wzajemne spojrzenie } \\
\text { (mutual attention/ } \\
\text { mutual gaze) }\end{array}$} & \multirow{3}{*}{$\begin{array}{l}\text { Partnerzy interakcji } \\
\text { patrzą na siebie } \\
\text { wzajemnie }\end{array}$} & $\begin{array}{l}\text { Blass, Lumeng, Patil, } \\
\text { 2007; }\end{array}$ \\
\hline & & MacLean i in., 2014; \\
\hline & & Reddy, 2003 \\
\hline \multirow{3}{*}{$\begin{array}{l}\text { Uwaga równoległa } \\
\text { (parallel attention) }\end{array}$} & \multirow{3}{*}{$\begin{array}{l}\text { Partnerzy interakcji } \\
\text { jednocześnie patrzą } \\
\text { na ten sam bodziec- } \\
\text { przedmiot, osobę lub } \\
\text { wydarzenie }\end{array}$} & Gaffan i in., 2010; \\
\hline & & $\begin{array}{l}\text { Osório, Martins, Meins, } \\
\text { Martins, Soares, } 201 \text {; }\end{array}$ \\
\hline & & Perra, Gattis, 2012 \\
\hline \multirow[t]{4}{*}{$\begin{array}{l}\text { Uwaga wspólna (joint } \\
\text { attention) }\end{array}$} & $\begin{array}{l}\text { Odpowiadanie } \\
\text { (responding): podążanie } \\
\text { za wzrokiem i gestem } \\
\text { drugiej osoby (patrzenie } \\
\text { tam, gdzie patrzy lub na } \\
\text { to, co wskazuje) }\end{array}$ & \multirow[t]{2}{*}{ Mundy, Newell, 2007} \\
\hline & $\begin{array}{l}\text { Inicjowanie (initiating): } \\
\text { wykorzystywanie gestów } \\
\text { i kontaktu wzrokowego, } \\
\text { aby ukierunkować } \\
\text { uwagę drugiej osoby }\end{array}$ & \\
\hline & $\begin{array}{l}\text { Delikatna (fragile): dwie } \\
\text { osoby patrzą na ten } \\
\text { sam obiekt (por. uwaga } \\
\text { równoległa) }\end{array}$ & \multirow[t]{2}{*}{ Butterworth, 2004} \\
\hline & $\begin{array}{l}\text { Solidna (robust): } \\
\text { obejmuje koordynację } \\
\text { uwagi w obrębie } \\
\text { trzech obiektów } \\
\text { uwagi i podzielanie } \\
\text { doświadczenia (sharing } \\
\text { experience) z drugą } \\
\text { osobą }\end{array}$ & \\
\hline
\end{tabular}




\subsection{Mimiczna ekspresja emocji}

Nieodłączną częścią interakcji dziecko-rodzic jest wyrażanie emocji, percepcyjne ich rozróżnianie oraz rozumienie różnych zachowań innych osób jako wyrazu ich stanów emocjonalnych. Wzajemna komunikacja wymaga zatem zdolności ekspresyjnych, jak i percepcyjnych. Ekspresja emocji podstawowych jest uniwersalna dla naszego gatunku i nie wymaga uczenia się (Ekman, 1994; Izard, 1994). Jednak nie oznacza to, że już w pierwszych miesiącach życia dziecko mimicznie wyraża wszystkie emocje w sposób równie czytelny, jak starsze dzieci i dorośli, ponieważ kontrola i koordynacja ruchów twarzy wymagają praktyki (por. Camras, Shutter, 2010) ${ }^{\mathbf{1 4}}$.

Rozróżnianie mimicznych ekspresji emocji jest możliwe dzięki rozwojowi widzenia i uwagi wzrokowej oraz gromadzeniu doświadczeń społecznych. Ze względu na problemy metodologiczne, np. to, że w różnych badaniach pokazywano niemowlętom twarze wyrażające różne emocje (a nie te same w podłużnym schemacie badawczym), trudno precyzyjnie określić sekwencję wyłaniania się umiejętności rozróżniania poszczególnych emocji. Według Field i współpracowników (Field, Woodson, Greenberg, Cohen,1982) 2-dniowe noworodki rozróżniają twarze wyrażające radość, smutek i zaskoczenie. Dziesięciotygodniowe niemowlęta rozróżniają twarze wyrażające radość, smutek i złość (Haviland, Lelwica, 1987). Niemowlęta 3-miesięczne odróżniają twarz uśmiechniętą od twarzy marszczącej brwi (Barrera, Maurer, 1981). Niemowlęta 4-miesięczne różnicują (odmiennie reagują na) radość, zaskoczenie, smutek, złość i strach, demonstrowane w zabawie „a kuku" (Montague, Walker-Andrews, 2001). W wieku 4-6 miesięcy niemowlęta rozróżniają złość, strach i zaskoczenie (Serrano, Iglesias, Loeches, 1992). Roczne dzieci rozróżniają wszystkie podstawowe mimiczne ekspresje emocji (Martin, Witherington, Edwards, 2008).

Między 5. a 7. miesiącem następuje zwiększenie wrażliwości niemowląt na mimiczną ekspresję strachu, która przejawia się wzrostem czasu patrzenia na twarze wyrażające strach oraz rzadszym i wolniejszym wycofywaniem uwagi z twarzy wyrażających strach w porównaniu z twarzami wyrażającym

14 Istnieją szczegółowe systemy oceny mimicznej ekspresji emocji u niemowląt i małych dzieci stosowane w badaniach naukowych. Najbardziej znanymi są Baby FACS (Oster, 2003), odwołujący się do teorii emocji podstawowych Ekmana (1994), oraz AFFEX (Izard, Dougherty, Hembree, 1983), opracowany w odniesieniu do teorii emocji odrębnych Izarda (1992). 
radość (Peltola, Leppänen, Hietanen, 2011; Peltola, Leppänen, Mäki, Hietanen, 2009). Ma to ważne znaczenie adaptacyjne, ponieważ wraz z rozwojem ruchowym rośnie autonomia dziecka w eksploracji przedmiotów i otoczenia oraz możliwość oddalania się od opiekuna.

Aby druga osoba rozumiała, że wyrażane przez dziecko emocje są kierowane do niej (adresowane), dziecko musi skoordynować ekspresję mimiczną $\mathrm{z}$ innym zachowaniem komunikacyjnym, np. ze skierowaniem spojrzenia na partnera interakcji, wyciągnięciem rąk, czy zbliżeniem się do niego. Lavelli i Fogel (2005) zbadali zmiany rozwojowe w uwadze wzrokowej i wyrażaniu emocji podczas interakcji niemowlę-matka twarzą w twarz w pierwszych miesiącach życia dziecka. Stwierdzili, że u dzieci, które skończyły 2 miesiące następowała zmiana rozwojowa, polegająca na łączeniu patrzenia na matkę z głużeniem i uśmiechaniem się. W tym samym okresie matki mówiły i uśmiechały się do swoich dzieci częściej niż we wcześniejszych tygodniach. Można uznać, że dziecko adresowało komunikaty emocjonalne do matki, matka natomiast identyfikowała siebie jako ich odbiorcę i adekwatnie na nie odpowiadała. Ten przykład obrazuje, w jaki sposób rosnące kompetencje dziecka wiążą się z zachowaniami interakcyjnymi rodzica. Skończywszy 2 miesiące, dzieci potrafiły za pomocą patrzenia na osobę adresować do niej komunikaty. Dzięki adresowaniu, interakcja diadyczna mogła nabrać charakteru dialogu. Zmieniło się zarówno zachowanie dziecka, jak i rodzica. Zmiana rozwojowa wyrażała się w zachowaniach diadycznych, czyli współtworzonych przez dziecko i rodzica.

Koordynacja różnych zachowań ekspresyjnych (np. uśmiechu, marszczenia brwi) z kierowaniem uwagi na matkę wzrasta $\mathrm{w}$ kolejnych miesiącach życia (Yale, Messinger, Cobo-Lewis, Delgado, 2003). Większa czytelność sygnałów emocjonalnych i jasne adresowanie ich do opiekuna ułatwiają osobom dorosłym zrozumienie zachowań dziecka i adekwatne reagowanie na komunikaty dziecka.

Ważnym zachowaniem rodzicielskim, polegającym na percepcji i ekspresji emocji w diadzie, jest odzwierciedlanie afektywne (affective mirroring). Polega ono na odtwarzaniu za pomocą własnej mimiki, głosu i gestów tej emocji, którą wyraziło dziecko. Zwykle naśladowanie to jest nadmiarowe tak, że wyrażany stan emocjonalny jest bardzo czytelny. Funkcją odzwierciedlania jest pokazanie dziecku, jak w lustrze społecznym, jego własnego zachowania. Kluczowa jest tutaj spójność, zgodność między zachowaniem afektywnym rodzica i bezpośrednio poprzedzającym je zachowaniem afektywnym dziecka, ponieważ buduje ona samoświadomość (odczuwanych 
stanów; Papoušek, 2007). Dzięki odzwierciedlaniu niemowlę zaczyna zdobywać wiedzę o swoich stanach emocjonalnych. Z czasem nauczy się, które stany zwykle towarzyszą określonym sytuacjom i jak się te stany nazywają.

Odzwierciedlanie jest zatem narzędziem regulacji emocji dziecka. Opisując tę funkcję odzwierciedlania, Gergely, Koós i Watson (2010) nazywają je „społecznym biofeedbackiem”. Podstawowe emocje, bezpośrednio związane z wyzwalającym je bodźcem i niepoddawane świadomej kontroli, mogą dzięki odzwierciedlaniu z czasem zostać uświadomione i kontrolowane, czyli regulowane samodzielnie przez dziecko (Gergely i in., 2010)

Odzwierciedlanie jest wyrazem dostrajania się do dziecka (Stern, 1985). Jasne komunikowanie dziecku, że jego uczucia są dostrzegane, rozumiane i akceptowane już od pierwszych miesięcy jego życia, kształtuje relację dziecko-opiekun. Jest jednym z zachowań, które sprzyja budowaniu relacji, w tym ufnego przywiązania dziecka do rodzica. To narzędzie kształtowania relacji i wspierania rozwoju emocjonalnego i społecznego dziecka jest stosowana spontanicznie przez większość rodziców podczas epizodów interakcyjnych twarzą w twarz z niemowlęciem. Odzwierciedlanie jest elementem intuicyjnego rodzicielstwa (intuitive parenting; Papoušek, 2007; Papoušek, Papoušek, 2002) - należy do repertuaru biologicznie zakorzenionych zachowań, które rodzice podejmują w sposób nieświadomy (tzn. bez wcześniejszego rozważania czy świadomego podejmowania decyzji).

Wpływ odzwierciedlania na rozwój mózgu dziecka wykazano w badaniu aktywności mózgowego systemu motorycznego (Rayson, Bonaiuto, Ferrari, Murray, 2017). Kiedy niemowlęta miały 2 miesiące, przeprowadzono obserwacje interakcji dziecko-matka, natomiast wieku 9 miesięcy mierzono u niemowląt desynchronizację rytmu mu podczas oglądania bodźców ${ }^{15}$. U niemowląt, których matki częściej odzwierciedlały otwieranie ust i uśmiech podczas interakcji w wieku 2 miesięcy, stwierdzono silniejszą desynchronizację rytmu mu 7 miesięcy później. Autorzy (Rayson i in., 2017) konkludują, że odzwierciedlanie wspiera rozwój łączenia („mapowania”) obserwowanych ekspresji mimicznych drugiej osoby z własnymi.

15 Rytm mu jest to wzorzec aktywności elektrycznej mózgu, rejestrowany przez elektrody umieszczone na powierzchni czaszki odpowiadającej obszarom kory sensomotorycznej. Desynchronizacja rytmu mu wiąże się z wykonywaniem, obserwowaniem i wyobrażaniem sobie celowej aktywności ruchowej (Nyström, Ljunghammar, Rosander, von Hofsten, 2011; Pineda, 2005). 


\subsection{Komunikowanie się za pomocą wielu zmysłów}

3.3.1. Dotyk. Ontogenetycznie najbardziej pierwotnym zmysłem jest dotyk (Maurer, Maurer, 1988). Wydaje się, że jest on najbardziej uniwersalnym narzędziem służącym regulacji poziomu pobudzenia dziecka, utrzymywaniu bliskości i komunikowania się z niemowlętami (Stack, 2008), a w szczególności przekazywaniu sygnałów emocjonalnych (Hertenstein, 2002). Kojące działanie ma zwłaszcza tzw. dotyk społeczny. Charakteryzuje się on lekkim naciskiem, ruchem głaszczącym o wolnym tempie i przekazywaniem temperatury ciała drugiej osoby (Brauer, Xiao, Poulain, Friederici, Schirmer, 2016).

W przeciwieństwie do głosu, niedostępnego dla dzieci głuchych, czy kontaktu wzrokowego, niedostępnego dla dzieci niewidomych, $\mathrm{z}$ dotyku rodzica mogą korzystać niemal wszystkie niemowlęta ${ }^{16}$. W badaniu wykazano, że podczas interakcji twarzą $\mathrm{w}$ twarz $\mathrm{w}$ ramach procedury laboratoryjnej rodzice dotykali niemowląt nawet przez ponad 65\% czasu (Stack, Muir, 1990). U niemowląt urodzonych przedwcześnie kontakt skóra do skóry (tzw. kangurowanie) jest rodzajem interwencji medycznej ratującej zdrowie i życie dziecka (WHO, 2003; metaanaliza w: Lawn, Mwansa-Kambafwile, Horta, Barros, Cousens, 2010). U wcześniaków kangurowanie ma również długoterminowy pozytywny wpływ na jakość interakcji dziecko-matka, dziecko-ojciec, a także na osiągnięcia rozwojowe dziecka mierzone za pomocą standardowej skali (Feldman, Eidelman, Sirota, Weller, 2002).

Dotyk rodzica podczas wykonywania przez niemowlę zadań poznawczych wpływa na uczenie się. W eksperymencie z udziałem 4-miesięcznych niemowląt wykazano, że niemowlęta, które podczas oglądania zdjęć twarzy były delikatnie głaskane przez matki, skutecznie uczyły się rozróżniać te twarze (Della Longa, Gliga, Farroni, 2019). Efekt uczenia się nie wystąpił w przypadku braku dotyku ani przy dotyku za pomocą miękkiego pędzelka. Zatem dotyk matki umożliwił dzieciom nauczenie się rozróżniania prezentowanych bodźców społecznych.

Związek między dotykiem w interakcjach i przetwarzaniem informacji społecznych stwierdzono również na poziomie mózgowym, badając wpływ doświadczeń dotykowych na aktywność mózgową pięciolatków (Brauer i in., 2016). W pierwszej części badania rejestrowano 10-minutową zabawę

16 Pewne bardzo rzadkie choroby skóry mogą jednak znacznie utrudniać kontakt za pomocą dotyku. Przykładem jest pęcherzowe oddzielanie się naskórka (WHO, 2018). 
dziecko-matka i mierzono, jak często matka dotykała dziecko. W drugiej części badania dokonano pomiaru spoczynkowej aktywności mózgu dziecka za pomocą rezonansu magnetycznego. U dzieci, które były częściej dotykane przez matki, stwierdzono wyższą aktywność oraz łączność funkcjonalną w niektórych obszarach należących do tzw. mózgu społecznego. Pewną słabością tego badania jest nieuwzględnienie informacji o zachowaniu dzieci oraz ich kompetencjach społecznych, ani zachowań diadycznych. W konsekwencji nie można ocenić, jaka była rola zachowań dziecka w interakcji z matką i jego własnych kompetencji społecznych, ani czy częstość dotyku była przejawem jakiejś innej właściwości dziecka, matki lub diady etc. Rola dotyku diadycznego w rozwoju poznawczym jest wciąż słabo poznana.

Dotyk odgrywa ważną rolę w rozwoju przywiązania, dlatego przyjmuje się, że jakość kontaktu dotykowego jest jednym ze wskaźników jakości przywiązania dziecko-rodzic. Ma to znaczenie kliniczne, ponieważ pewne właściwości dotyku diadycznego są specyficzne dla niektórych zaburzeń rozwoju emocjonalnego u dzieci. W badaniu z udziałem dzieci poniżej 3 . roku życia i ich matek, pacjentów poradni zdrowia psychicznego, oraz grupy kontrolnej, analizie poddano interakcje podczas zabawy i podczas karmienia dziecka (Feldman, Keren, Gross-Rozval, Tyano, 2004). Stwierdzono, że dotyk w diadach dziecko $\mathrm{z}$ zaburzeniami karmienia-matka miał pewne właściwości odróżniające go od dotyku w diadach z dziećmi z innymi zaburzeniami i bez zaburzeń. Dotyczyło to nie tylko dotyku podczas karmienia, ale także podczas swobodnej zabawy. Dotyk w tych diadach był mniej czuły, a dzieci i matki częściej odrzucały dotyk drugiej osoby. Wynik ten wskazuje na relacyjny charakter zaburzeń karmienia. Dotyk w diadzie był behawioralnym wskaźnikiem jakości relacji dziecko-matka. Oznacza to, że właśnie w niej należałoby szukać źródła tych zaburzeń.

Wyniki powyższego badania potwierdzają znaczenie analizy interakcji w pracy klinicznej z małymi dziećmi i ich rodzicami. Poprzez analizę zaobserwowanych zachowań, narzędzie to pozwala zrozumieć psychiczne podłoże objawów, które przejawia diada. Tak jak zachowania mają charakter diadyczny (analizowaną jednostką jest diada, a nie pojedyncze osoby), tak i zaburzenie obejmuje diadę, nawet jeżeli powodem zgłoszenia do klinicysty są objawy występujące u dziecka. Myślenie o zaburzeniach behawioralnych u dziecka jako o wyrazie zaburzeń relacji ma swoje źródła w klasycznych pracach dotyczących relacji rodzic-niemowlę, np. Brazeltona i Cramera (1990), oraz systemowym ujęciu rodziny (zob. de Barbaro, 1999). 
3.3.2. Słuch i mowa. Zdolność do odróżniania głosu matki od innych głosów obecna jest u noworodków, a także przed narodzinami (Hepper, Scott, Shahidullah, 1993). Ponadto noworodki preferują głos własnej matki (DeCasper, Fifer, 1980). Zdolności percepcyjne i umiejętność produkowania różnego rodzaju dźwięków to kolejne elementy wyposażenia behawioralnego niemowląt, które służą rozwojowi przywiązania dziecko-rodzic (Querleu i in., 1984; Sullivan, Perry, Sloan, Kleinhaus, Burtchen, 2011). Pozwalają one niemowlętom uczestniczyć w skoordynowanych wymianach wokalnych - protodialogach (protokonwersacjach). Ich kluczową właściwością jest naprzemienność (zob. Gratier i in., 2015; Jasnow, Feldstein, 1986; Yoo, Bowman, Oller, 2018). Rodzice wprowadzają naprzemienność, dostosowując swoje zachowanie do rytmu wokalizacji dziecka. Czekają, aż dziecko skończy wokalizować i wtedy rozpoczynają swoją wypowiedź (czasem wypowiedzi partnerów interakcji nieznacznie na siebie zachodzą) i przerywają, jeżeli dziecko znów podejmie wokalizację. Dzięki temu niemowlęta poznają naprzemienną strukturę komunikacji językowej i ćwiczą dostosowywanie swojego zachowania we wzajemnych dynamicznych wymianach językowych.

Oprócz poznawania czasowej organizacji komunikacji, niemowlęta uczą się używać wokalizowania, aby kształtować przebieg interakcji. Na przykład $\mathrm{w}$ badaniu $\mathrm{z}$ udziałem niemowląt 6-miesięcznych w paradygmacie kamiennej twarzy (zob. rozdział 3.3.2) zaobserwowano, że dzieci zmieniały natężenie swojego głosu, rodzaj produkowanych dźwięków i częstość wokalizacji w zależności od zachowania rodzica (Franklin i in., 2014). Jest to kolejny dowód na to, że w pierwszych miesiącach życia kompetencje komunikacyjne dziecka wyłaniają się w interakcjach z opiekunami.

W badaniu wykazano, że dopasowanie czasowe podczas interakcji wokalnych niemowlę-matka oraz niemowlę-obcy w wieku 4 miesięcy pozwala przewidywać wyniki rozwojowe dziecka w wieku 12 miesięcy (Jaffe i in., 2001). Stwierdzono, że średni poziom koordynacji (interakcja uporządkowana, ale nie sztywna) w wieku 4 miesięcy wiązał się z ufnością przywiązaniową, kiedy dzieci miały rok. Natomiast wysoki poziom koordynacji wiązał się z lepszymi wynikami w skali rozwojowej. Nie bez znaczenia była również koordynacja osoba obca-matka dziecka. Co ważne, dynamika interakcji wokalnych różniła się między diadami dziecko-matka i dziecko-obcy (np. $\mathrm{w}$ interakcjach z obcymi pauzy były krótsze), a także między warunkami: w domu versus w laboratorium (Jaffe i in., 2001). Wyniki te wskazują na konieczność uwzględniania kontekstu - relacji między osobami (np. osoby bliskie versus obce) oraz otoczenia (np. miejsce znane versus nieznane) 
- w analizie interakcji. Celowe wydaje się obserwowanie dzieci nie tylko $\mathrm{w}$ interakcjach $\mathrm{z}$ bliskimi, ale również z osobami obcymi, tak w domu, jak i poza nim. Warto również zwrócić uwagę na przebieg interakcji rodzic-inna osoba dorosła.

Jednym ze sposobów dostrajania się dorosłych do niemowląt jest zwracanie się do nich w pewien szczególny sposób, określany jako mowa kierowana do niemowlęcia lub dziecka (infant/child-directed speech, baby talk), mowa matczyna (motherese) lub mowa rodzicielska (parentese). Charakteryzuje się ona wysokim tonem głosu, uproszczeniami w składni i słownictwie oraz wyrazistą intonacją i wymową (Fernald, 1985; Milewski, 2009, 2011). Noworodki i niemowlęta wolą słuchać wypowiedzi o takich właściwościach niż mowy, jaką zwykle posługują się dorośli między sobą (Cooper, Aslin, 1990; Fernald, 1985; Pegg, Werker, McLeod, 1992). Zatem używanie mowy kierowanej do niemowlęcia lub dziecka wspomaga jego zaangażowanie w interakcje. Ponadto taki sposób mówienia do dziecka sprzyja rozwojowi mowy, pod warunkiem, że wypowiedzi są spójne semantycznie i czasowo z aktywnością i zachowaniami komunikacyjnymi dziecka (McGillion i in., 2013).

Mowa kierowana do dziecka jest bodźcem bardziej wyrazistym niż mowa kierowana do dorosłych. Dzięki temu, że wymowa dźwięków jest spowolniona, a przerwy między słowami i zdaniami są uwypuklone, dziecku łatwiej jest wychwytywać poszczególne dźwięki, słowa i zdania z ciągu wypowiedzi (Golinkoff, Can, Soderstrom, Hirsh-Pasek, 2015). Schachner i Hannon (2011) zademonstrowali, że niemowlęta 5-miesięczne dłużej patrzyły na twarz osoby, która wcześniej używała mowy skierowanej do dziecka niż na twarz nowej osoby. Nie stwierdzili takiej zależności w przypadku osoby, która mówiła tak, jak zwykle mówi się do dorosłych. Autorzy (Schachner, Hannon, 2011) wyjaśniają, że podczas pierwszych miesięcy życia niemowlęta zdążyły nauczyć się, że to właśnie od osób używających baby talk mogą oczekiwać opieki i okazji do uczenia się.

W niektórych sytuacjach pewne właściwości mowy kierowanej do dzieci nie różną się znacząco od mowy kierowanej do dorosłych. Na przykład komunikaty silnie nacechowane emocjonalnie mają podobne właściwości akustyczne, niezależnie od wieku adresata (Trainor, Austin, Desjardins, 2000). Trainor i in. (2000) argumentują, że różnice między mową kierowaną do dzieci i do dorosłych wynikają w znacznej mierze z tego, że ekspresja emocjonalna dorosłych $\mathrm{w}$ interakcjach $\mathrm{z}$ dziećmi jest bardziej swobodna, podczas gdy w interakcjach dorosły-dorosły osoby hamują ekspresję emocji. Natomiast inni badacze twierdzą, że niemowlęta preferują mowę do nich 
kierowaną, ponieważ jest ona zwykle wysycona pozytywnymi emocjami (Singh, Morgan, Best, 2002). W cytowanym badaniu 6-miesięczne niemowlęta dłużej patrzyły na twarze mówiące radosnym głosem niż na twarze mówiące neutralnym tonem, zarówno kiedy używano mowy kierowanej do dziecka, jak i mowy kierowanej do dorosłych. Te badania pokazują, że pomimo obszernej literatury przedmiotu wciąż pojawiają się nowe pytania dotyczące mowy kierowanej do dziecka. Przyczyniają się do tego różnice w metodach badań i charakterystykach badanych grup.

$\mathrm{W}$ interakcjach dziecko-rodzic mowa jest narzędziem regulacyjnym dla obu stron. Mowa dorosłych zmienia się wraz z wiekiem i kompetencjami dziecka: od kojącego tonu i śpiewu, przez werbalne odzwierciedlanie afektywne, po nazywanie emocji, ukierunkowywanie uwagi dziecka, wyjaśnianie i doradzanie. Dziecko stopniowo opanowuje język, by móc go używać do kształtowania interakcji, organizowania swojego doświadczenia i kierowania zachowaniem. Na przykład dzieci przedszkolne mówią do siebie na głos podczas wykonywania złożonych zadań. Jest to mowa prywatna (private speech), która w rozwoju przekształca się w mowę wewnętrzną i pełni rolę narzędzia samoregulacji przez całe życie (Clowes, 2007; Kielar-Turska, 2013; Winsler, 2009; Wygotski, 1934/1989). Co ważne, jednym z mechanizmów włączania mowy prywatnej w struktury psychiki dziecka są interakcje z bliskimi. Berk i Spuhl (1995) wyjaśniają, że dzieci internalizują kierowaną do nich mowę, co daje początek mowie prywatnej, a następnie wewnętrznej. Język mówiony może oczywiście zostać zastąpiony ekwiwalentem w postaci języka migowego i spełniać te same funkcje (zob. Hall, Levin, Anderson, 2017; Tomaszewski, Rosik, 2002).

Zmysły węchu i smaku również odgrywają rolę w interakcjach dzieckorodzic, szczególnie w najwcześniejszym okresie życia (Corona, Lévy, 2015; Nishitani i in., 2009; Varendi, Porter, Winberg, 1994). Jednak ze względu na bardzo ograniczoną możliwość regulowania własnego zapachu w celu kształtowania przebiegu interakcji, zagadnienia te nie będą tutaj poruszane.

3.3.3. Wielozmysłowość. Dotychczas, ze względu na jasność wywodu, skupiono się na opisie badań dotyczących poszczególnych zmysłów. Tymczasem interakcje dostarczają doświadczeń, które są wielozmysłowe (wielomodalne, multimodal), czyli w tym samym czasie dostarczają bodźców do więcej niż jednego zmysłu. Dzięki czasowemu zsynchronizowaniu informacji uzyskiwanych z różnych zmysłów powstają spójne doświadczenia (Bahrick, 2010). Z wyników badań niemowląt wynika, że: (1) początkowo 
informacje dochodzące z różnych narządów zmysłów są doświadczane jako amodalne, czyli jako jedna całość, a w rozwoju stają się międzyzmysłowe (międzymodalne, intermodal) ${ }^{\mathbf{1 7}}$, tzn. zaczynają być postrzegane jako składające się z informacji dochodzących z różnych zmysłów; (2) informacje wielomodalne są redundantne, tzn. ta sama informacja jest przekazywana za pomocą więcej niż jednego zmysłu, przez co są wyraziste i ukierunkowują uwagę niemowlęcia; (3) redundancja i wiążąca się z nią integracja informacji z różnych zmysłów są niezbędne w prawidłowym rozwoju społecznym (Bahrick, 2010; Bahrick, Lickliter, 2000). Wielozmysłowość jest kolejnym interakcyjnym mechanizmem rozwoju dziecka we wczesnym okresie życia.

Potrzeba doświadczeń wielozmysłowych ujawnia się w interakcjach dziecko-rodzic. Niemowlęta dotykają twarzy opiekuna, przyglądając się jej, a dorośli tak organizują interakcje, że możliwy jest kontakt wzrokowy, słuchowy i fizyczny. Wrażliwy rodzic wie, że aby ukoić niemowlę, często trzeba je wziąć na ręce, przytulić, ukołysać, podać smoczek i mówić do niego, czyli dostarczyć bodźców za pośrednictwem różnych narządów zmysłów. Rohlfing i Nomikou (2014) stwierdzają, że międzyzmysłowe, spójne reakcje rodzica są narzędziem dostrajania się do dziecka. Niedostępność niektórych zmysłów, np. wzroku czy słuchu, może być skutecznie kompensowana, co nadaje interakcjom szczególny charakter.

\subsection{Interakcje z wykorzystaniem przedmiotów i odniesień do otoczenia}

Po początkowym okresie zaangażowania głównie w interakcje osoba-osoba, w wieku około 2 miesięcy u niemowląt wyłania się umiejętność manipulowania przedmiotem, a w wieku około 3 miesięcy - manipulowania przedmiotem, który trzyma druga osoba (Perra, Gattis, 2012). Jest to więc okres stopniowego nabywania zdolności uczestniczenia w interakcjach osoba-osoba-przedmiot. Umiejętnością, która pozawala na angażowanie się w takie interakcje, Butterworth (2004) nazywa słabą bądź kruchą wspólną uwagą (fragile joint attention). Oznacza to, że chociaż dziecko jeszcze nie podziela uwagi w taki sposób, jak pod koniec 1. roku życia, wykazuje ono pewne zachowania będące prekursorem tej umiejętności. Wzrost zdolności

17 Natomiast termin „percepcja międzyzmysłowa” (intermodal perception) odnosi się do zdolności rozpoznania obiektu percypowanego za pomocą jednego zmysłu (np. dotyku), który poznano wcześniej za pomocą innego zmysłu (np. wzroku). Zwięzły przegląd badań na ten temat Czytelnik znajdzie w podręczniku Schaffera i Kipp (2015). 
uwagowych u niemowląt $\mathrm{w}$ wieku około 3 miesięcy wiąże się m.in. z rozwojem korowej kontroli ruchu oczu i łączeniem wizualnych cech bodźców (orientacji w przestrzeni, koloru, ruchu) tak, że możliwe jest ich rozpoznawanie (Johnson, de Haan, 2018)

Uwaga 3-miesięcznego niemowlęcia nadal w znacznej mierze podlega kontroli zewnętrznej (Johnson, 1994). Dlatego też jego eksploracja wzrokowa jest uzależniona od partnera, który kształtuje interakcje z wykorzystaniem przedmiotów, prezentując je, podając dziecku do ręki, zabierając, czy umieszczając dziecko w pozycji pozwalającej mu obserwować otoczenie. Typowymi zachowaniami osób dorosłych w interakcjach $\mathrm{z}$ niemowlętami po 2. miesiącu życia jest monitorowanie uwagi dziecka oraz pokazywanie i nazywanie przedmiotów, na które ono patrzy. Niemowlęta utrzymują na nich uwagę oraz poznają za pomocą różnych zmysłów (Rączaszek-Leonardi, Nomikou, Rohlfing, 2013). Taki wzorzec interakcji, z pewnymi modyfikacjami, jest nadal obecny w dalszym rozwoju. W badaniu z udziałem matek i 14-miesięcznych dzieci wykazano, że matki miały tendencję do włączania się w eksplorację przedmiotu, którym manipulowało dziecko, oraz mówienia o nim lub zadawania dziecku pytań dotyczących tego przedmiotu (Tamis-LeMonda, Kuchirko, Tafuro, 2013). Struktura interakcji pozostała podobna do tej w okresie niemowlęctwa, natomiast zmianie uległy komunikaty rodzicielskie. Stały się one bardziej złożone i wymagały od dziecka udzielania werbalnych odpowiedzi.

Około 4. miesiąca życia wyłania się umiejętność wolicjonalnej (endogennej) kontroli uwagi wzrokowej - skupiania jej, utrzymywania, wycofywania i przenoszenia (Colombo, 2001; Johnson 1990, 1994; Johnson, de Haan, 2018; Johnson i in., 1991). Dzięki temu dziecko w swojej wzrokowej eksploracji otoczenia jest coraz mniej zależne od opiekunów. Czas utrzymywania uwagi na osobach, przedmiotach oraz częstość przenoszenia uwagi w coraz większym stopniu zależy od indywidualnych cech dziecka, takich jak temperament, szybkość uczenia się, motywacja, a u dzieci z zaburzeniami rozwoju także od rodzaju zaburzenia. Wymienione cechy dziecka są jednymi z wielu czynników indywidualnych kształtujących jego interakcje z innymi osobami.

Podczas gdy zdolność niemowlęcia do kontrolowania swojej uwagi wzrasta, rodzice wciąż regulują zachowania uwagowe dziecka. Na przykład kiedy rodzice 5-miesięcznych niemowląt zachowują się w sposób wrażliwy i niedyrektywny (tu: nie próbują przekierować uwagi dziecka), niemowlęta częściej patrzą na przedmioty, które rodzice trzymają (Mason, Kirkpatrick, 
Schwade, Goldstein, 2018). W ten sposób zachowania interakcyjne rodziców organizują procesy poznawania elementów otoczenia przez niemowlę.

Zmiany w zachowaniach interakcyjnych diady są ściśle powiązane ze zdobywaniem przez dziecko nowych umiejętności. Połączenie kompetencji w obszarach kontroli uwagi, pamięci roboczej (Reynolds, Romano, 2016), motoryki (siedzenie i siadanie, sięganie i kontrola chwytania; Rochat, de Campos, Silva, Tudella, 2013) oraz koordynacji oko-ręka (np. Rochat, 1992) pozwala półrocznemu dziecku sprawnie poznawać przedmioty. Nie jest więc zaskakujące, że dzieci w tym wieku angażują się w eksplorację przedmiotów, a mniej w interakcję osoba-osoba bez użycia przedmiotów (Bakeman, Adamson, 1984). Mają również tendencję do skupiania uwagi na rodzicach, kiedy manipulują oni przedmiotami. Poza wzrostem zainteresowania dziecka przedmiotami, z wiekiem zmienia się również koordynacja zachowań rodziców i dzieci. W badaniu podłużnym poddano analizie zachowania wzrokowe matek i niemowląt wieku 3, 6 i 8 miesięcy w trakcie zmieniania pieluszki (Nomikou, Leonardi, Rohlfing, Rączaszek-Leonardi, 2015). Czas uwagi wzajemnej spadał, a czas patrzenia na przedmioty wzrastał po 3. miesiącu. Wzrastała również koordynacja wzrokowa niemowlę-matka, tzn. zachowania partnerów interakcji były sparowane w węższych oknach czasowych. Wyniki te są kolejnym dowodem na to, że koordynacja interpersonalna wyłania się w interakcji. Ma to ogromne znaczenie rozwojowe, gdyż złożone wymiany społeczne, takie jak komunikowanie się za pomocą języka czy współpraca, wymagają od partnerów interakcji precyzyjnego synchronizowania swoich działań.

Kiedy dziecko siada, wstaje lub chodzi, zbiera inne doświadczenia wzrokowe, niż kiedy leży, czy raczkuje. Stawia także inne wymagania przed partnerem interakcji, jeśli chodzi o dostosowywanie jego zachowań do zachowań dziecka (Franchak, Kretch, Adolph, 2018). Im większa mobilność, tym więcej uwagi dziecko poświęca przedmiotom i otoczeniu. Oczywiście rozwój lokomocji ściśle wiąże się z rozwojem przywiązania dziecko-rodzic: wraz z wiekiem, wzrasta liczba zachowań eksploracyjnych polegających na fizycznym oddalaniu się, a zmniejsza liczba zachowań przywiązaniowych opartych na bliskości fizycznej (Ainsworth, Bell, 1970; Bowlby, 1969/2007). Samodzielna lokomocja pozwala także dziecku zwiększać dystans fizyczny i psychiczny względem osób, przedmiotów i miejsc w różnych sytuacjach, na przykład gdy wzbudzają one lęk.

Lokomocja daje dziecku nowe możliwości kształtowania interakcji z opiekunami. Opiekunowie natomiast zwykle dostosowują swoje zachowanie do 
zmieniających się możliwości ruchowych dziecka (a także uwarunkowań środowiskowych i kulturowych, stąd różnice w rozwoju motorycznym dzieci z różnych kultur, np. dzieci afrykańskich i amerykańskich; Super, 1976; Super, Harkness, 1986). W ten sposób działa interakcyjne sprzężenie zwrotne - mechanizm podtrzymujący stabilność, a zarazem napędzający zmiany rozwojowe w interakcjach dziecko-rodzic. Przykładem zmiany związanej $\mathrm{z}$ rozwojem lokomocji jest wzrost liczby rozumianych i wypowiadanych słów wraz z początkiem chodzenia, niezależnie od wieku dziecka w momencie osiągnięcia tej umiejętności (Walle, Campos, 2014). Chociaż pełne zrozumienie tej zależności wymaga dalszych badań, autorzy spekulują, że uwolnienie rąk pozwala dziecku manipulować przedmiotami, przenosić je i podawać rodzicowi, który z kolei je nazywa (Walle, Campos, 2014). Ponadto u rodziców większa samodzielność ruchowa dziecka może wzmacniać postrzeganie go jako odrębnej osoby, zmieniając sposób komunikowania się z nim. Empiryczna weryfikacja tej hipotezy byłaby wartościowa ze względu na znaczenie osobowego traktowania dziecka w rozwoju jego tożsamości (por. Zalewska, 1998, 2004).

U typowo rozwijających się dzieci w wieku 9-12 miesięcy następuje jakościowa zmiana w kompetencjach uwagowych, która ma znaczący wpływ na strukturę interakcji i możliwości komunikowania się dziecka z innymi osobami. Wspólna uwaga, przez Butterwortha (2004) określana jako solidna (robust), polega na tym, że dziecko kieruje uwagę na obiekt, a zarazem monitoruje uwagę rodzica (spogląda na niego), którego uwaga również skierowana jest na ten obiekt. W czwartym trymestrze 1. roku życia niemowlęta zaczynają koordynować patrzenie na przedmioty, ludzi i wydarzenia z patrzeniem na partnera interakcji i nawiązywaniem z nim kontaktu (wzrokowego, werbalnego), aby komunikować się na temat obserwowanych obiektów. Adresowanie zachowania do rodzica może polegać na nawiązaniu kontaktu wzrokowego, wskazywaniu czy wokalizacji lub komunikacie werbalnym.

Odwołując się do innej koncepcji, można powiedzieć, że osiągnięcie biegłości w uwspólnianiu uwagi jest możliwe dzięki coraz skuteczniejszemu funkcjonowaniu mózgowej sieci uwagi wykonawczej (executive attention) ${ }^{\mathbf{1 8}}$, która odpowiada m.in. za wolicjonalną regulację uwagi i jest pod pewnymi

18 W literaturze polskojęzycznej termin executive tłumaczy się również jako „zarządzający” lub „zarządczy”, także w odniesieniu do szerszego pojęcia funkcji zarządzających lub zarządczych (np. Kielar-Turska, Białecka-Pikul, Skórska, 2006; Nęcka i in., 2007). 
względami bardziej dojrzałym następcą systemu kontroli uwagi zależnego od uwagowej sieci orientacyjnej (Posner, Rothbart, Voelker, 2016; Rothbart, Sheese, Rueda, Posner, 2011).

Uwspólnianie uwagi jest podstawą bardziej złożonego, w porównaniu $\mathrm{z}$ interakcjami osoba-osoba, podzielania stanów psychicznych. Zmianę tę obrazuje badanie, w którym udział wzięły dzieci w wieku 6 i 12 miesięcy. Dzieci 12-miesięczne częściej przenosiły wzrok z przedmiotu na opiekuna, kiedy wyrażały pozytywne emocje, niż kiedy ich afekt był neutralny. Takiej prawidłowości nie zaobserwowano u dzieci 6-miesięcznych (Kuroki, 2007). Wynik ten można zinterpretować jako wyraz zdolności starszych niemowląt do podzielania $\mathrm{z}$ rodzicem radości płynącej z zabawy przedmiotem.

O wspólnej uwadze mówi się również, kiedy dziecko podąża za wzrokiem drugiej osoby, tzn. przenosi wzrok na bodziec, na który patrzy druga osoba. Podobnie jest, kiedy patrzy we wskazanym przez nią kierunku i kiedy samo wskazuje. Patrzenie we wskazanym kierunku to odpowiadanie, a ukierunkowywanie uwagi drugiej osoby to inicjowanie wspólnej uwagi. Jest to ważne rozróżnienie m.in. dlatego, że poważne deficyty w inicjowaniu wspólnej uwagi są typowe dla autyzmu, natomiast odpowiadanie ma mniejszą wartość diagnostyczną (część dzieci z autyzmem odpowiada na inicjatywy drugiej osoby; Mundy, Sullivan, Mastergeorge, 2009). Jakościowo różne są także dwa rodzaje wskazywania: imperatywne (komunikujące prośbę czy nakaz, np. „Daj mi to!”) i deklaratywne (mające na celu podzielanie doświadczenia, np. „Zobacz!"). Rozróżnienie to również ma znaczenie diagnostyczne i kliniczne (np. Legerstee, Fisher, 2008; Olafsen i in., 2012; ale zob. też: Białek, Białecka-Pikul, Stępień-Nycz, 2014). Wskazywanie imperatywne i deklaratywne różnią się intencją i mogą odmiennie wyglądać. Gdy dzieci chcą coś dostać, częściej wyciągają całą dłoń, a gdy chcą, aby dorosły spojrzał na to, na co one patrzą, częściej wskazują za pomocą wyprostowanego palca wskazującego (Cochet, Vauclair, 2010).

Dzieci, które mają wyższy poziom umiejętności uwspólniania uwagi (w tym inicjowania i odpowiadania) często w przyszłości mają wyższe osiągnięcia rozwojowe, szczególnie w obszarze rozwoju języka (Brooks, Meltzoff, 2005; Mundy, Block, Delgado, Pomares, Van Hecke, Parlade, 2007) oraz teorii umysłu (Baron-Cohen, 1991; Charman i in., 2000). Dlatego wspomaganie rozwoju wspólnej uwagi w interakcjach jest ważnym elementem interwencji, np. w terapii autyzmu (Kasari, Gulsrud, Paparella, Hellemann, Berry, 2015).

Wspólny wkład rodziców i dziecka w kształtowanie interakcji jest kluczowy dla wyłaniania się złożonych zdolności uwagowych. Według de Barbaro, 
Johnson i Deáka (2013) wspólna uwaga wyłania się płynnie, a nie w postaci skoku rozwojowego. Jest ona wynikiem coraz bardziej złożonych i skoordynowanych sensomotorycznych interakcji dziecko-rodzic, którym ramy nadaje rodzic. Rolę koordynacji podkreślają również Yu i Smith (2016a), którzy w swoim badaniu obserwowali koordynację oczy-ręce podczas poznawania nowych przedmiotów przez diadę. Wykazali, że jedną ze ścieżek prowadzących do uwspólniania uwagi jest podążanie za ruchem dłoni partnera interakcji, kiedy manipuluje on przedmiotem.

Uwaga wzrokowa w interakcjach ma charakter diadyczny, czyli jest procesem wspólnie konstruowanym przez osoby, a nie tylko właściwym jednostce. Yu i Smith (2016b) zaobserwowali, że roczne dzieci były w stanie dłużej utrzymywać uwagę na przedmiotach, kiedy na przedmioty te patrzyli również ich partnerzy interakcyjni. Zatem zachowanie diadyczne (uwaga równoległa) wiązało się z kompetencją dziecka - zdolnością do utrzymywania uwagi. Wykazano również, że czas trwania kontaktu wzrokowego w interakcji niemowlę w wieku 6 miesięcy-matka pozwalał przewidywać zdolność dziecka do kontroli uwagi w wieku 12 miesięcy (Niedźwiecka, Ramotowska, Tomalski, 2017). W diadach, które dłużej pozostawały w kontakcie wzrokowym, niemowlęta osiągały wyższy poziom kontroli uwagi. Co ważne, tylko zachowanie diadyczne (uwaga wzajemna), a nie indywidualne zachowania wzrokowe (czasy patrzenia: dziecko na obiekt, dziecko na matkę, matka na dziecko, matka na obiekt), było predyktorem kompetencji uwagowej dziecka. Wynik ten pokazuje, że obserwacja zachowań diadycznych umożliwia lepsze poznanie mechanizmów rozwoju poznawczego we wczesnym dzieciństwie.

Komunikowanie się na temat, możliwe dzięki uwspólnianiu uwagi, ma ważne znaczenie adaptacyjne. Rosnąca zdolność dziecka do samodzielnego poruszania się daje mu większą autonomię oraz pozwala coraz efektywniej poznawać otoczenie. Wynikają z niej jednak pewne zagrożenia. Dzięki komunikowaniu się na temat, nawet nie będąc w bezpośredniej bliskości dziecka, opiekun może uchronić je przed urazami, wykorzystując np. kontakt wzrokowy. Jest to możliwe między innymi dzięki wyłonieniu się u dziecka w wieku około 12 miesięcy umiejętności stosowania odniesienia społecznego.

W klasycznych badaniach z wykorzystaniem „wzrokowego urwiska” obserwowano zachowanie dzieci w sytuacji niepewności (Sorce, Emde, 
Campos, Klinnert, 1985) ${ }^{19}$. Niepewność ta dotyczyła postrzeganego zagrożenia. Dzieci musiały zdecydować, czy podjąć próbę przejścia po płaszczyźnie, która wyglądała, jakby była znacznie nachylona. Wiele dzieci w wieku około 12 miesięcy i starszych stosowało odniesienie społeczne, to znaczy spoglądało na rodzica, który komunikował różne emocje. Kiedy rodzic wyrażał strach, żadne z badanych dzieci nie przeszło na drugą stronę płaszczyzny. Kiedy wyrażał złość, tylko niektóre podjęły to ryzyko. Wyniki tych badań pokazują, że roczne dzieci potrafią regulować swoje zachowanie, odwołując się do informacji o uwadze wzrokowej opiekuna i jego stosunku emocjonalnym do elementu środowiska. Jest to kolejny przykład adaptacyjnej funkcji diadycznych zachowań uwagowych w rozwoju dziecka.

Podsumowując, w 1. roku życia kompetencje interakcyjne dziecka rozwijają się bardzo dynamicznie. Początkowo interakcje mają strukturę osobaosoba (interakcje diadyczne), następnie, od około 3. miesiąca życia struktura ta może obejmować trzy osoby (interakcje triadyczne). Ponadto dzięki wsparciu partnera interakcji, dzieci w tym wieku coraz sprawniej eksplorują przedmioty. Jest to początkowy etap nabywania umiejętności uczestniczenia w interakcjach o strukturze osoba-osoba-przedmiot lub temat, która wyłania się około 9. miesiąca ${ }^{20}$. Pod koniec 1. roku życia dziecko wykorzystuje w interakcjach zdolności motoryczne i poznawcze, aby w złożony sposób komunikować się i poznawać świat. Pozwolą one dziecku w następnych latach opanowywać kolejne, coraz bardziej złożone umiejętności, niezmiennie osadzone w interakcjach społecznych.

19 Pierwotnie wzrokowe urwiska stosowano w badaniach dotyczących percepcji głębi (Gibson, Walk, 1960).

20 Interakcje osoba-osoba mają podstawę w „pierwotnej intersubiektywności”, a osobaosoba-przedmiot we „wtórnej intersubiektywności” (primary/secondary intersubjectivity; Trevarthen, Aitken, 2001). Tomasello (1995) pisze natomiast o „zaangażowaniu diadycznym” i „zaangażowaniu triadycznym” (dyadic/triadic engagement). 


\section{PRZEgLĄD BADAŃ NAD INTERAKCJAMI DZIECI Z ZABURZENIAMI ROZWOJU}

Rozdział ten zawiera krótkie zestawienie wyników badań nad interakcjami diad dziecko z zaburzeniami rozwoju-rodzic (lub dziecko z ryzykiem wystąpienia zaburzeń rozwoju-rodzic). Ponieważ w różnych badaniach te same terminy mogą być różnie rozumiane i operacjonalizowane, ich znaczenie będzie wyjaśniane, jeżeli różni się od definicji przedstawionych we wcześniejszych rozdziałach tej książki.

Lata badań nad interakcjami zaowocowały powstaniem szeregu skutecznych metod terapeutycznych. W tym rozdziale krótko zostanie opisana metoda Parent-Child Interaction Therapy (PCIT; Funderburk, Eyberg, 2011), jednak nadmienić należy również takie narzędzia terapeutyczne, jak Wideotrening Komunikacji (Biemans, 1990; Kennedy, Landor, Todd, 2010; Piełuć, Fludra, 2010), metodę Marte Meo (Aarts, 2000; Høivik i in., 2015; Vik, Rohde, 2014) czy Interwencję promującą pozytywne rodzicielstwo przez videofeedback (Juffer, Bakermans-Kranenburg, van IJzendoorn, 2012, 2017).

\subsection{Dzieci z zaburzeniami ze spektrum autyzmu}

U osób z zaburzeniami ze spektrum autyzmu (autism spectrum disorders, ASD) występują nieprawidłowości w interakcjach społecznych i komunikacji społecznej oraz ograniczone, sztywne wzorce zachowań i zainteresowań (WHO, 2018). Już w 1. roku życia mogą pojawiać się objawy wskazujące na ryzyko wystąpienia ASD (Jones, Johnson, 2017; Rybakowski i in., 2014). Chociaż wcześniejsze wyniki badań wskazywały, że rzetelną diagnozę można postawić najwcześniej u 2-latków (zob. Matson, Wilkins, González, 2008), nowsze badania wskazują na wysoką stabilność diagnoz stawianych już u dzieci 14-miesięcznych (Pierce i in., 2019) lub 16-miesięcznych (Cervantes, Matson, Goldin, 2016). Ze względu na podwyższone ryzyko wystąpienia 
ASD u młodszego rodzeństwa dzieci z autyzmem - prawie jedna piąta z nich również otrzymuje diagnozę ASD; Shephard i in., 2017) - dzieci te obejmuje się obserwacją psychiatryczną i psychologiczną.

Większość osiowych objawów ASD ujawnia się w interakcjach społecznych. Dlatego można powiedzieć, że za kluczowe nieprawidłowości $\mathrm{w}$ interakcjach (np. krótki czas patrzenia na partnera interakcji, rzadkie inicjowanie wspólnej uwagi, niskie zaangażowanie we wspólną aktywność) odpowiadają objawy dziecka. W zabawie dzieci z ASD dominuje aktywność z wykorzystaniem przedmiotu, bez udziału drugiej osoby (Bentenuto, de Falco, Venuti, 2016; Kasari, Gulsrud, Wong, Kwon, Locke, 2010), co w połączeniu z deficytami w zakresie niewerbalnej i werbalnej komunikacji oraz teorii umysłu i sztywnością zachowania, stawia przed partnerem interakcji szczególne wyzwania. W terminach teorii ekologicznej, środowisko społeczne, jakie tworzy dziecko z ASD, zawiera więcej ograniczeń i mniej afordancji, które pozwalałyby obojgu uczestnikom na inicjowanie i podtrzymywanie satysfakcjonujących interakcji.

Freeman i Kasari (2013) porównały zabawę dzieci z rodzicami w dwóch grupach: dzieci z autyzmem i dobranej pod względem poziomu rozwoju językowego grupie dzieci typowo się rozwijających. Oceniano rodzaj i złożoność zabawy (od zabaw manipulacyjnych, przez proste zabawy na niby, po zabawy polegające na odgrywaniu ról), a także kategoryzowano akty komunikacyjne jako nakazy, sugestie albo naśladowanie. Okazało się, że chociaż podczas oceny poziomu rozwoju zabawy z eksperymentatorem dzieci typowo się rozwijające uzyskały wyższe wyniki niż dzieci z autyzmem, w zabawie $z$ rodzicami poziom ten był podobny w obu grupach. Natomiast rodzice dzieci z autyzmem częściej nakazywali i proponowali, a także odpowiadali na zachowanie dziecka poprzez wprowadzanie zabawy na wyższym poziomie niż ta, którą wybrało dziecko. W grupie dzieci typowo się rozwijających rodzice najczęściej odpowiadali zabawą dopasowaną pod względem poziomu rozwojowego do zabawy dziecka. Wyniki te pokazują, że podczas zabawy rodzice dzieci $z$ autyzmem byli bardziej dyrektywni i mniej dostrojeni do zachowania dziecka. Taki styl interakcyjny można określić jako nadmiernie wymagający. Chociaż zachowanie tych rodziców można tłumaczyć dążeniem do wspierania rozwoju dziecka, z perspektywy dziecka mogło ono być frustrujące (rodzic nadmiernie ingerował w aktywność dziecka, a proponowana przez niego zabawa wykraczała ponad jego możliwości). W efekcie interakcje $\mathrm{w}$ grupie dzieci $\mathrm{z}$ autyzmem cechowały się większym niedopasowaniem niż interakcje w grupie dzieci typowo się rozwijających. 
Pewnym niedostatkiem w opisie zachowań zabawowych uczestników przedstawionego badania jest brak informacji o emocjach wyrażanych przez dzieci i rodziców. Niedopasowanie przywodzi na myśl raczej epizody interakcyjne o negatywnym bądź neutralnym zabarwieniu emocjonalnym. Tymczasem zabawa, z definicji, wiąże się z pozytywnym afektem (Krasnor, Pepler, 1980; Smith, Vollstedt, 1985), a podzielanie pozytywnych emocji jest ważnym elementem komunikacji dziecko-rodzic. Obserwacja ekspresji emocjonalnej pozwala stawiać hipotezy m.in. odnośnie do tego, jak uczestnicy interakcji doświadczają wspólnej aktywności, czyli umożliwia odnoszenie obserwowanych zachowań do stanów psychicznych osób.

Dawson, Hill, Spencer, Galpert i Watson (1990) w swoim badaniu dobrali dzieci $z$ autyzmem i dzieci rozwijające się typowo, tak aby grupy nie różniły się pod względem rozwoju językowego (wiek chronologiczny dzieci z ASD od 1,5 do 5,8 lat). Obserwacja składała się z trzech części: zabawy swobodnej, wspólnego sprzątania po zabawie oraz interakcji twarzą w twarz, podczas której dzieci siedziały $\mathrm{w}$ wysokim foteliku, a matki podawały im przekąskę. Jeśli chodzi wyrażane emocje, istotne różnice międzygrupowe zaobserwowano podczas interakcji twarzą w twarz. Chociaż grupy nie różniły się pod względem częstości czy całkowitego czasu uśmiechania się, bardziej szczegółowe analizy wykazały, że dzieci z autyzmem rzadziej uśmiechały się, jednocześnie utrzymując kontakt wzrokowy z matkami. Ponadto w grupie dzieci $z$ autyzmem dzieci rzadziej uśmiechały się w odpowiedzi na uśmiech matek, a matki tych dzieci rzadziej uśmiechały się w odpowiedzi na uśmiech dzieci. Podsumowując, wyniki wskazały, że dzieci z autyzmem rzadziej adresowały uśmiech do matek, oraz że diady dziecko z autyzmem-matka rzadziej podzielały radość (osoby rzadziej odpowiadały uśmiechem na uśmiech). Zatem, $\mathrm{w}$ porównaniu $\mathrm{z}$ diadami typowymi, $\mathrm{w}$ diadach dziecko z autyzmem-matka komunikacja i współdzielenie emocji pozytywnej było ograniczone.

W jednym z nielicznych badań z udziałem ojców, Pisula (2008) stwierdziła, że podczas zabawy dzieci z autyzmem płakały i krzyczały częściej niż dzieci z zespołem Downa i dzieci rozwijające się typowo. Dzieci z autyzmem rzadziej podejmowały temat zabawy proponowany przez ojców i rzadziej adresowały do nich wokalizacje (wokalizowały, nawiązując kontakt wzrokowy). Taką charakterystykę zachowań interakcyjnych można uznać za wyraz trudności typowych dla ASD. Natomiast ojcowie dzieci z autyzmem częściej niż ojcowie z pozostałych grup próbowali nawiązać kontakt fizyczny z dziećmi. Ponadto, tak jak w wcześniej opisanym badaniu, ojcowie dzieci 
z autyzmem (a także ojcowie dzieci z zespołem Downa) częściej niż ojcowie dzieci rozwijających się typowo sugerowali dziecku, w co się bawić. Wcześniejsze badanie $\mathrm{z}$ udziałem matek dało podobne wyniki: podczas zabawy matki dzieci z autyzmem były bardziej dyrektywne niż matki dzieci rozwijających się typowo, a także rzadziej odpowiadały na zachowania dziecka, a dzieci z autyzmem częściej płakały, krzyczały i odsuwały się od matek (Pisula, 2003). Autorka proponuje model przyczynowo-skutkowy, który może wyjaśniać utrzymywanie się takiego wzorca interakcyjnego w diadach dziecko z autyzmem-matka. Dziecko ma tendencję do samotnej zabawy, nie kieruje uwagi na matkę i nie reaguje na jej inicjatywy. W odpowiedzi na to, matka usiłuje skierować na siebie jego uwagę i przekierować jego aktywność tak, aby doszło do aktywności wspólnej. Dziecko coraz bardziej opiera się powtarzającym się dyrektywnym zachowania matki i protestuje, aż dochodzi do przerwania kontaktu. Matka rezygnuje z dalszych prób zaangażowania dziecka, a dziecko powraca do aktywności bez udziału matki. Można skonkludować, że diady dziecko z autyzmem-rodzic mają trudność w uwspólnianiu aktywności, w ich interakcjach często brakuje wzajemnej uwagi i dopasowania, przez co mniej niż w interakcjach typowo się rozwijających dzieci jest pozytywnych emocji, ich podzielania i współprzeżywania.

Cenny materiał badawczy stanowią przeanalizowane przez Trevarthena i Daniela (2005) nagrania wykonane pod koniec 1. roku życia sióstr bliźniaczek jednojajowych. U jednej z nich zdiagnozowano autyzm w wieku 18 miesięcy, druga rozwijała się typowo. Interakcje córka-ojciec zostały zarejestrowane w domu przez matkę dziewczynek.

Autorzy przyjęli, że obserwowaną jednostką jest diada (a nie każdy uczestnik z osobna). Pierwszym analizowanym epizodem była zabawa twarzą w twarz. Stwierdzono, że ojciec i córka typowo się rozwijająca zdecydowanie dłużej na siebie patrzyli, a w zabawie można było wyodrębnić pewną strukturę, polegającą na stopniowym wzrastaniu napięcia, a także antycypacji i podzielaniu radości. Ojciec i córka, u której później zdiagnozowano autyzm, krótko patrzyli na siebie (ojciec dłużej niż córka), a krótkie epizody radości były raczej skutkiem kontaktu fizycznego niż częścią złożonej sekwencji zachowań w toku zabawy, która w pierwszej diadzie rozwijała się jak rodzaj historii. Zachowanie diad różniło się także w sytuacji triadycznej córka-córka-ojciec. Zaobserwowano głównie interakcje w diadzie typowo rozwijająca córka-ojciec, która cechowała się wzajemną uwagą i radością oraz samotną aktywność drugiej dziewczynki. Ponadto w trakcie interakcji $\mathrm{w}$ diadzie ojciec był bardziej dyrektywny w interakcji z córką rozwijającą się 
nietypowo. Wynik ten jest spójny z wynikami dwóch wcześniej opisanych badań (Freeman, Kasari, 2013; Pisula, 2008).

Interakcje dziecko $\mathrm{z}$ autyzmem-rodzic różnią się od interakcji typowych również pod względem właściwości czasowych. Przeprowadzono badanie na dużej grupie dzieci, które polegało na nagrywaniu przez cały dzień dźwięków wydawanych przez dziecko i jego otoczenie (Warlaumont i in., 2010). W ciągu dnia dzieci nosiły przytwierdzone do ubrania małe urządzenie nagrywające, a zebrany materiał został przeanalizowany w celu wyłonienia wokalizacji i mowy dziecka i osób dorosłych (rodziców, opiekunów w przedszkolu, terapeutów) z tła obejmującego odgłosy wegetatywne, dźwięki dobiegające z telewizora, ciszę itd. Okazało się, że w interakcjach z dziećmi z ASD dorośli zwykle reagowali na wokalizacje dziecka z pewnym opóźnieniem w porównaniu z grupą kontrolną. Również dzieci z ASD odpowiadały na wokalizacje dorosłych później niż dzieci typowo się rozwijające, chociaż różnica ta nie osiągnęła poziomu istotności statystycznej. Ponieważ u dzieci z ASD stwierdza się nieprawidłowości w czasowym przetwarzaniu bodźców (Morimoto, Hida, Shima, Okamura, 2018; Stevenson i in., 2016; Szeląg, Kowalska, Gałkowski, Pöppel, 2004), możliwe, że spowolnienie reakcji dorosłych (w porównaniu $\mathrm{z}$ ich reakcjami na wokalizacje dzieci rozwijających się typowo) może być wyrazem dostrajania się do dziecka. Co ważne, w badaniu analizowano wyłącznie strukturę czasową interakcji wokalnych, bez względu na zawartość treściową wypowiedzi czy ich ładunek afektywny. Uwzględnienie tych zmiennych pozwoliłoby lepiej zrozumieć przebieg i jakość interakcji wokalnych w tej grupie osób.

$\mathrm{W}$ interakcjach dziecko $\mathrm{z}$ autyzmem-rodzic ujawniają się kryterialne objawy zaburzeń ze spektrum autyzmu, wpływając na przebieg interakcji. Im większe jest nasilenie tych objawów u dziecka, tym niższa ogólna jakość interakcji (obejmująca m.in. koordynację, komunikowanie się i afekt) i ko-regulacji oraz poziom zaangażowania (Hobson, Tarver, Beurkens, Hobson, 2016). Z drugiej strony, im wyższa jakość interakcji, tym lepsze funkcjonowanie dziecka. Na przykład w badaniu z wykorzystaniem Skali do oceny interakcji społecznych (Ruble i in., 2008; zob. też: rozdział 2.3) jeden $\mathrm{z}$ aspektów responsywności - spójność (odpowiednio szybkie reakcje, które jednocześnie są treściowo spójne z zachowaniem dziecka) wiązała się z umiejętnościami społecznymi dziecka. Matki, których zachowanie oceniono jako bardziej spójne, wyżej oceniały kompetencje dziecka w zakresie inicjowania interakcji społecznych (Ruble i in., 2008). Dlatego też coraz częściej elementem terapii autyzmu są interwencje mające na celu 
poprawę różnych aspektów interakcji dziecko-rodzic (Ginn i in., 2017; Shire i in., 2016; Solomon, Ono, Timmer, Goodlin-Jones, 2008).

Obecnie wiele badań obejmują dzieci z wysokim ryzykiem wystąpienia ASD ze względu na obciążenia rodzinne. Zwykle są to niemowlęta i małe dzieci, które mają starsze rodzeństwo z diagnozą ASD (w dalszej części rozdziału będą określane mianem dzieci z ryzykiem). Istnieje coraz więcej danych dotyczących wczesnych objawów nietypowego rozwoju u dzieci, które w późniejszym okresie życia otrzymują diagnozę ASD, w szczególności w obszarze rozwoju ruchowego, uwagi i przetwarzania informacji zmysłowych (Johnson, Gliga, Jones, Charman, 2015; Jones, Gliga, Bedford, Charman, Johnson, 2014). Zaobserwowano również trajektorie rozwoju charakterystyczne dla tych dzieci, np. po 2. miesiącu życia postępujący spadek czasu patrzenia na twarze (Jones, Klin, 2013). Natomiast pewne zachowania interakcyjne dzieci z ryzykiem pod koniec 1. roku życia są predyktorem późniejszej diagnozy ASD.

$\mathrm{W}$ badaniu z wykorzystaniem systemu do oceny interakcji MACI (zob. rozdział 2.3) stwierdzono, że w interakcjach niemowlę z ryzykiem-rodzic, kiedy dzieci miały od 6 do 10 miesięcy, niemowlęta były mniej aktywne ruchowo, a rodzice mniej wrażliwi i responsywni oraz bardziej dyrektywni niż w diadach z grupy kontrolnej (Wan i in., 2012). W wieku 12 miesięcy niemowlęta $z$ ryzykiem były mniej uważne na rodzica i wyrażały mniej pozytywnych emocji, a rodzice byli bardziej dyrektywni w porównaniu z diadami z grupy kontrolnej. Ponadto interakcje diad z ryzykiem cechowały się niższym poziomem wzajemności i intensywnego zaangażowania. Niższa uważność na rodzica, gorszy afekt dziecka i niższa wzajemność były predyktorami diagnozy ASD w wieku 36 miesięcy (Wan i in., 2013).

Responsywność i dyrektywność matek oraz emocje wyrażane przez dziecko (uśmiech kierowany do rodzica, czyli współwystępujący z kontaktem wzrokowym) oceniano również $\mathrm{w}$ badaniu podłużnym z pomiarami w wieku 9 i 18 miesięcy (Harker, Ibañez, Nguyen, Messinger, Stone, 2016). Podobnie jak w badaniach dzieci z diagnozą autyzmu (Freeman, Kasari, 2013; Pisula, 2008; Trevarthen, Daniel, 2005), matki niemowląt z ryzykiem były bardziej dyrektywne niż matki dzieci bez ryzyka. Zarówno w grupie dzieci z ryzykiem, jak i bez - dzieci częściej się uśmiechały, gdy matki były bardziej responsywne. Ponadto okazało się, że wraz z wiekiem dzieci z ryzykiem coraz częściej uśmiechały się do matek, podczas gdy dzieci bez ryzyka - mniej. Autorzy tłumaczą ten wynik rozwojowo prawidłowym spadkiem częstości uśmiechania się, kiedy tę formę kontaktu zastępują bardziej 
złożone zachowania komunikacyjne, takie jak gesty czy język (Harker i in., 2016). Utrzymywanie się komunikacji za pomocą uśmiechu byłoby zatem pochodną opóźnienia w rozwoju językowym dzieci z ryzykiem wystąpienia autyzmu.

Kolejne dwa badania również uwzględniły afekt dziecka, a ponadto synchronię diadyczną, która jednak była różnie rozumiana. W pierwszym badaniu zastosowano procedurę kamiennej twarzy oraz oceniano swobodną zabawę dziecka z matką za pomocą systemu do analizy faz monadycznych (zob. rozdział 2.3), kiedy niemowlęta miały 4 miesiące, a następnie mierzono poziom rozwoju dziecka i komunikację niewerbalną w wieku 14 miesięcy (Yirmiya i in., 2006). Podczas procedury kamiennej twarzy niemowlęta z ryzykiem różniły się od grupy kontrolnej pod względem ekspresji emocjonalnej, a mianowicie przez dłuższy czas ich afekt został oceniony jako neutralny. Ponadto w grupie z ryzykiem, im dłużej afekt dziecka w wieku 4 miesięcy był neutralny, tym niższy wynik uzyskiwało ono w zadaniu oceniającym inicjowanie wspólnej uwagi w wieku 14 miesięcy. Prawidłowości takiej nie stwierdzono u dzieci bez ryzyka zaburzeń rozwoju. Są to kolejne wyniki ukazujące różnice w ekspresji emocji podczas interakcji u dzieci z ryzykiem w porównaniu z dziećmi bez ryzyka. Po drugie, neutralny afekt, może mieć inne znaczenie rozwojowe w zależności od istnienia ryzyka wystąpienia ASD bądź jego braku. Lepsze zrozumienie znaczenia neutralnego afektu u dzieci z ryzykiem, podczas gdy matka ma „kamienną twarz”, wymaga dalszych badań. Synchronia (tu: współwystępowanie tego samego natężenia stanów u dziecka i matki) podczas interakcji w wieku 4 miesięcy nie była związana $\mathrm{z}$ osiągnięciami rozwojowymi dziecka w wieku 14 miesięcy.

W drugim badaniu mianem synchronicznych określono takie zachowania rodzica, które wiązały się z obiektami uwagi dziecka (Steiner, Gengoux, Smith, Chawarska, 2018). Jeżeli zachowanie takie nie wymagało od dziecka wykonania czynności, określano je jako synchroniczne-niedyrektywne. Natomiast jeżeli zachowanie to obejmowało prośbę, sugestię lub nakaz, było kodowane jako synchroniczne-dyrektywne. Całkowity czas trwania zachowań synchronicznych-dyrektywnych był wyższy w grupie z ryzykiem ASD. Ponadto im wyższe było nasilenie objawów ASD u dziecka w wieku 12 miesięcy, tym wyższa była dyrektywność rodzica. Stwierdzono również istnienie związku między synchronicznymi-dyrektywnymi zachowaniami rodzica, jego poziomem stresu i negatywnym nastrojem dziecka. Matki, które zachowywały się bardziej dyrektywnie, wyżej oceniły swój poziom stresu związanego z częstością negatywnego nastroju u dziecka. Ze względu 
na korelacyjny charakter badania oraz brak obserwacyjnej oceny nastroju uczestników interakcji, wyniki te można interpretować na różne sposoby, jednak o ich wartości stanowi możliwość formułowania hipotez na potrzeby przyszłych badań.

Kolejnymi zachowaniami, które odróżniają grupy dzieci z ryzykiem i późniejszą diagnozą ASD od dzieci bez ryzyka, jest poziom wzajemności oraz częstość dawania i pokazywanie rodzicowi zabawek w wieku 11 miesięcy (Campbell, Leezenbaum, Mahoney, Day, Schmidt, 2015). Co więcej, opisano pewien wzorzec wyników uzyskanych przez trzy grupy dzieci. Dzieci bez ryzyka uzyskały najwyższe wyniki w obszarach pozytywnego afektu, dawania i pokazywania zabawek oraz adresowanych wokalizacji. Dzieci ryzykiem i późniejszą diagnozą uzyskały wyniki najniższe z wszystkich trzech grup, a dzieci z ryzykiem, które nie otrzymały diagnozy - wyniki średnie. Taki wzorzec wyników odzwierciedla istnienie tzw. szerszego spektrum autystycznego, czyli występowania u członków rodzin osób z ASD, którzy nie mają takiej diagnozy, pewnych objawów o subklinicznym nasileniu (Piven, Palmer, Jacobi, Childress, Arndt, 1997; przegląd dotyczący rodzeństwa dzieci z ASD w: Pisula, Ziegart-Sadowska, 2015). Stąd gorsze wyniki rodzeństwa $\mathrm{z}$ ryzykiem, lecz bez autyzmu, w porównaniu z dziećmi bez ryzyka. Jednocześnie w badaniu tym nie stwierdzono różnic międzygrupowych w zachowaniach interakcyjnych rodziców (Campbell i in., 2015). Również w niedawnym badaniu (Schwichtenberg, Kellerman, Young, Miller, Ozonoff, 2019) nie stwierdzono różnic między matkami dzieci z ASD i bez ani pod względem ogólnej responsywności społecznej ocenianej za pomocą kwestionariusza przez partnerów kobiet, ani w ocenie ich zachowań podczas zabawy z młodszym dzieckiem. Kiedy podzielono dzieci na trzy grupy: rodzeństwo z ryzykiem, które później rozwijało się nietypowo, rodzeństwo z ryzykiem, które rozwijało się typowo i dzieci bez ryzyka, również nie było różnic między matkami w responsywności społecznej, ani w zachowaniu podczas zabawy.

W grupie dzieci z ryzykiem ASD, u których później diagnozuje się autyzm, już około 1. urodzin może występować opóźnienie rozwoju językowego (Jones, Gliga, Bedford, Charman, Johnson, 2014). Stąd zainteresowanie wokalnymi interakcjami w pierwszym roku życia tych dzieci. Swanson i in. (2018) analizowali całodzienne nagrania wokalizacji niemowląt w wieku 9 miesięcy. Ustalili, że wśród dzieci z ryzykiem była grupa niemowląt, które wokalizowały znacznie więcej niż niemowlęta bez ryzyka. Jednocześnie, proporcja wymian konwersacyjnych (czyli wokalizacji dziecka i rodzica 
występujących w odstępie nie dłuższym niż 5 sekund) u tych bardzo aktywnych wokalnie niemowląt była mniejsza niż u niemowląt wokalizujących z przeciętną częstością. Według autorów może to oznaczać, że niemowlęta te „monologują" lub też, że ich wokalizacje mają charakter zachowań repetytywnych bądź stereotypowych (Swanson i in., 2018), a nie komunikacyjnych. Zatem jeszcze zanim dziecko wkroczy w etap posługiwania się słowami, wskaźnikiem nietypowego rozwoju językowego może być produkowanie dużej liczby wokalizacji, które nie służą komunikowaniu się z drugą osobą (nie budują naprzemiennych, dialogowych interakcji).

Specyfika interakcji wokalnych dzieci z ryzykiem, które rozwijają się nietypowo, może również dotyczyć struktury czasowej dialogów. W interakcjach 9-miesięcznych niemowląt z ryzykiem, u których później zdiagnozowano opóźnienie rozwoju językowego, stwierdzono częstsze nachodzenie na siebie wokalizacji dziecka i matki (w szczególności: dzieci zaczynały wokalizować, zanim matki zdążyły zakończyć swoją wypowiedź) oraz niższy poziom koordynacji czasowej (Northrup, Iverson, 2015). Koordynacja operacjonalizowana tu była jako korelacja między latencjami: jeżeli czas od zakończenia wokalizacji jednej osoby do rozpoczęcia wypowiedzi przez drugą był podobny u matki i dziecka, koordynacja była oceniana jako wysoka, jeżeli te czasy znacznie się różniły, koordynacja była niska. Zatem brak zgrania w czasie podczas wymian wokalnych był predyktorem opóźnienia rozwoju językowego u dzieci z ryzykiem ASD.

Nie można tu pominąć prac, w których nie stwierdzono różnic między grupami dzieci z ryzykiem i bez. Na przykład w jednym z badań porównywano wokalizacje 9-miesięcznych niemowląt podczas zabawy z matkami (Talbott, Nelson, Tager-Flusberg, 2016). Niemowlęta z ryzykiem wystąpienia ASD nie różniły się pod względem częstości produkowanych dźwięków (samogłosek i dwudźwięków samogłoska-spółgłoska) od niemowląt nieobciążonych, a ich matki nie różniły się pod względem częstości reakcji werbalnych ani ich zawartości treściowej (potwierdzanie, pytanie itd.) od matek z grupy kontrolnej.

Jak opisano wcześniej, dzieci z ASD mają tendencję do angażowania się w zabawę samodzielną, bez uwzględniania drugiej osoby oraz ignorują inicjatywy rodzica. W takiej sytuacji rodzic może reagować zachowaniami dyrektywnymi. Pewne jego cechy mogą zwiększać prawdopodobieństwo wystąpienia niekorzystnych wzorców interakcyjnych i podtrzymywać je. Po pierwsze mogą to być „cechy autystyczne” związane z szerokim spektrum autystycznym. Hipotezę taką testowano w badaniu z udziałem dzieci 
i matek, które brały udział w programie wczesnej interwencji mającym na celu rozwijanie komunikacji społecznej u dzieci za pośrednictwem rodziców. W spotkaniach terapeutycznych uczestniczyli tylko rodzice (Parr i in., 2015). U matek oceniano jakość zachowań interakcyjnych oraz szeroki fenotyp autystyczny, a u dzieci poziom rozwoju językowego. Przed interwencją nie stwierdzono istotnych statystycznie związków między fenotypem autystycznym matek i ich zachowaniami interakcyjnymi ani rozwojem językowym dziecka. Natomiast po zakończeniu interwencji stwierdzono, że u matek z niskim nasileniem cech autystycznych korzystna zmiana zachowań była większa niż u matek $\mathrm{z}$ wyższym nasileniem cech autystycznych, a u ich dzieci nastąpił większy wzrost umiejętności językowych (w szczególności mowy biernej). Zatem skuteczność interwencji częściowo zależała od nasilenia cech matek związanych $\mathrm{z}$ fenotypem autystycznym.

Po drugie, na zachowania rodzica w interakcjach z dzieckiem może wpływać doświadczany przez niego stres. Wyniki badań wskazują m.in., że matki dzieci z autyzmem czują się mniej kompetentne i mają mniejszą satysfakcję ze związku małżeńskiego niż matki dzieci rozwijających się typowo (Rodrigue, Morgan, Geffken, 1990). Matki i ojcowie dzieci z autyzmem gorzej oceniają funkcjonowanie rodziny i własne funkcjonowanie w tej rodzinie oraz wyżej oceniają poziom stresu związanego z rodzicielstwem, a niżej jakość swojego życia niż rodzice dzieci zdrowych (Pisula, Porębowicz-Dörsmann, 2017). Ponadto ustalono, że rodzice małych dzieci, które niedawno otrzymały diagnozę ASD, jako grupa mieli wyższy średni poziom stresu i wyższe wyniki w skali depresji niż grupa kontrolna (Davis, Carter, 2008). Autorzy badania podkreślają jednak, że wyniki około 50\% rodziców dzieci niedawno zdiagnozowanych nie wskazywały na znaczące podwyższenie poziomu stresu czy objawów depresyjnych.

Trzecim czynnikiem, który może kształtować zachowania interakcyjne rodziców dzieci z autyzmem, są oddziaływania terapeutyczne mające na celu redukcję objawów ASD i wspomaganie rozwoju starszego dziecka. Na przykład niektóre metody terapii i nauczania osób z ASD polegają na dość dyrektywnych zachowaniach wobec dziecka (kierowanie jego aktywnością, sztywne przestrzeganie określonego schematu, dążenie do zrealizowania celów określonych przez dorosłego). Pojawia się pytanie, czy rodzice mogą odtwarzać taki schemat zachowań wyuczony w terapii dziecka z ASD w swoich interakcjach z młodszym dzieckiem. Oczywiście trudno ustalić, w jakim stopniu zachowania rodziców wobec młodszych dzieci są kształtowane przez wyuczone techniki postępowania ze starszym dzieckiem z ASD, ponieważ 
wymagałoby to porównania rodzin uczestniczących w różnego rodzaju interwencjach, przy jednoczesnym kontrolowaniu wielu innych zmiennych. $\mathrm{Z}$ drugiej strony, zachowania rodziców dzieci z ryzykiem ASD, wyuczone czy spontaniczne, mogą odpowiadać na specyficzne potrzeby rozwojowe tych dzieci. Na przykład, ustalono, że matki 12-miesięcznych dzieci z ryzykiem wykonywały więcej gestów niż matki dzieci bez ryzyka, chociaż dzieci z obu grup nie różniły się pod względem liczby wykonywanych gestów (Talbott, Nelson, Tager-Flusberg, 2015). Częstsze gestykulowanie matki wiązało się natomiast z wyższym poziomem rozwoju językowego dziecka w wieku 18 miesięcy, tak u dzieci z ryzykiem, jak i bez. Chociaż różnica ta może wynikać $\mathrm{z}$ zachowań nieocenianych w cytowanym badaniu, może również oznaczać, że matki dzieci z ryzykiem wspomagały komunikowanie się z dzieckiem za pomocą zwiększonej liczby gestów, co mogło sprzyjać rozwojowi językowemu dzieci.

Niedawny przegląd badań dotyczących interakcji dziecko z ryzykiem autyzmu-rodzic w pierwszych dwóch latach życia dziecka Czytelnik znajdzie w pracy Wan, Greena i Scotta (2019). Analizując te wyniki, warto zwrócić uwagę na fakt, że badania różnią się pod względem liczby dzieci z ryzykiem, które później otrzymują diagnozę ASD. Problem ten wymaga uwagi, ponieważ oznacza, że wyniki mogą być nierównoważne. W niektórych badaniach efekt statystyczny może zależeć od wyników uzyskanych przez dzieci z późniejszą diagnozą ASD (kiedy były one stosunkowo liczne w danej próbie), a w innych - od wyników dzieci z ryzykiem bez późniejszej diagnozy (w przypadkach, kiedy dzieci z diagnozą było niewiele).

Pomimo pewnych ograniczeń metodologicznych badań z udziałem młodszego rodzeństwa dzieci z ASD, wiedza o ich interakcjach z rodzicami pozwala lepiej zrozumieć mechanizmy typowego i zaburzonego rozwoju. Badania te pozwalają śledzić rozwój dzieci z ryzykiem od pierwszych miesięcy życia i identyfikować zachowania sygnalizujące późniejsze wystąpienie zaburzeń rozwoju, a także zachowania nietypowe, które jednak nie wiążą się z późniejszymi trudnościami rozwojowymi oraz zachowania kompensacyjne i te, które chronią przed patologią rozwoju. W praktyce klinicznej nie są jeszcze dostępne narzędzia, które pozwalałyby identyfikować niemowlęta, u których w przyszłości rozwinie się autyzm (Zwaigenbaum i in., 2015). Jednak, dzięki rozwojowi różnych narzędzi badawczych, w tym analizie interakcji niemowlę-rodzic, specjaliści mogą obejmować pomocą terapeutyczną coraz młodsze dzieci i ich rodziców. Istnieją pierwsze raporty $\mathrm{z}$ badań randomizowanych wskazujące na skuteczność interwencji skoncentrowanych 
na zachowaniach rodzicielskich, głównie mających na celu podnoszenie wrażliwej responsywności rodzica, które dedykowane są niemowlętom w drugim półroczu życia mających rodzeństwo z ASD (Green i in., 2015; Green, Garg, 2018) oraz rocznym dzieciom, które określono jako grupę ryzyka ze względu na występowanie u nich pewnych wczesnych objawów ASD (Watson $\mathrm{i}$ in., 2017).

\subsection{Dzieci z zespołem Downa}

Zespół Downa (trisomia 21. chromosomu) jest zaburzeniem genetycznym, które wiąże się z nieprawidłowościami w rozwoju fizycznym i psychicznym, występującym w przybliżeniu u jednego na 1000 żywo narodzonych dzieci (WHO). Częstość występowania różni się w zależności od wieku matki oraz poziomu rozwoju gospodarczego kraju (Christianson, Howson, Modell, 2006). Wśród osób z zespołem Downa istnieje znaczne zróżnicowanie pod względem poziomu intelektualnego, jednak większość dzieci jest upośledzonych umysłowo w stopniu umiarkowanym (Hodapp, Thornton-Wells, Dykens, 2009). Pod względem funkcjonowania poznawczego fenotyp behawioralny dzieci z zespołem Downa wyłania się i zmienia wraz z wiekiem. Cechuje się spowolnieniem szybkości uczenia się, trudnościami w planowaniu i rozwiązywaniu problemów oraz deficytami w pamięci roboczej i długotrwałej (Grieco, Pulsifer, Seligsohn, Skotko, Schwartz, 2015). Opóźnienie rozwoju poznawczego ujawnia się w pierwszych dwóch latach życia i staje się coraz bardziej wyraźne w wieku 2-4 lat (Chapman, Hesketh, 2000). $Z$ wiekiem poziom inteligencji spada (Sigman i in., 1999). W sferze języka charakterystyczna jest przewaga rozumienia (mowy biernej) nad ekspresją (mową czynną; Chapman, Hesketh, 2000; Sigman i in., 1999). Dzieci z zespołem Downa uchodzą za towarzyskie i empatyczne, jednak występują u nich również opozycyjność, upór i zachowania eksternalizacyjne (Grieco i in., 2015). Podsumowując, dzieci z zespołem Downa mają charakterystyczny profil zdolności poznawczych i zachowań społecznych. Stanowią one o specyficznych właściwości interakcji dziecko z zespołem Downa-rodzic.

Dzieci z zespołem Downa później niż ich typowo rozwijający się rówieśnicy zaczynają skupiać uwagę na twarzy partnera interakcji i nawiązywać z nim kontakt wzrokowy, jednak w dalszym rozwoju patrzą na bodźce społeczne dłużej niż dzieci rozwijające się typowo (Cebula, Wishart, 2008). Również uśmiech społeczny (adresowany do określonej osoby) u dzieci z zespołem Downa pojawia się z opóźnieniem (Berger, Cunningham, 1986). 
Ponadto uśmiech ten jest znacznie mniej wyraźny, blady, w porównaniu z uśmiechem dzieci rozwijających się typowo (Emde, Katz, Thorpe, 1978). Śmiech wzbudzany różnymi bodźcami (słuchowymi, dotykowymi, wzrokowymi) także pojawia się z opóźnieniem i jest ściśle związany z rozwojem poznawczym (Cicchetti, Sroufe, 1976). Taka ścieżka rozwoju ekspresji pozytywnych emocji stawia przed partnerami interakcji szczególne wyzwania. Po pierwsze, dostrzeżenie sygnałów dziecka wymaga większej wrażliwości. Po drugie, jakość uśmiechu społecznego może powodować, że jest on mniej nagradzający, co wynika z jego niskiej intensywności. Wreszcie, w perspektywie długoterminowej, opiekunowie dzieci o spowolnionym rozwoju emocjonalnym mogą odczuwać frustrację ze względu na długi czas oczekiwania na bardziej intensywne, pozytywne reakcje dziecka, zarówno na bodźce społeczne, jak i niespołeczne.

Tendencji dzieci z zespołem Downa do patrzenia na osoby towarzyszy rzadsze patrzenie na przedmioty (Kasari, Mundy, Yirmiya, Sigman, 1990; Legerstee, Weintraub, 1997). De Campos, da Costa, Savelsbergh i Rocha (2013) stwierdzili, że dzieci z zespołem Downa rzadziej niż dzieci typowo się rozwijające sięgały po przedmioty. Ponadto po chwyceniu przedmiotu rzadziej go eksplorowały (wkładały do ust, wykonywały ruchy większych partii ciała i ruchy precyzyjne dłoni i palców), a częściej upuszczały. Zatem stosunkowo niska wzrokowa eksploracja przedmiotów ściśle wiąże się ze zdolnościami ruchowymi i koordynacją wzrokowo-ruchową dziecka. W konsekwencji u dzieci z zespołem Downa eksploracja przedmiotów jest ograniczona. Badacze (Cebula, Wishart, 2008) zwracają uwagę na dwie kwestie: (1) dzieci z zespołem Downa mogą preferencyjnie patrzeć na bodźce społeczne, ponieważ eksploracja przedmiotów stanowi większe wyzwanie pod względem poznawczym, (2) w związku z powyższym, dzieci te mogą mieć mniej możliwości ćwiczenia przenoszenia uwagi między przedmiotami i ludźmi. Ponieważ kompetencja ta jest niezbędna w interakcjach osobaosoba-przedmiot, u dzieci z zespołem Downa mogą występować trudności w tym obszarze.

Niedawna metaanaliza (Hahn, Loveall, Savoy, Neumann, Ikuta, 2018) wskazała, że dzieci z zespołem Downa nie różnią się pod względem podzielania uwagi od typowo rozwijających się dzieci w podobnym wieku umysłowym, natomiast mają wyższe umiejętności w tym obszarze niż dzieci $z$ innymi niepełnosprawnościami i dziećmi $z$ autyzmem. Jednak pewne umiejętności są u nich na niższym poziomie, np. niewerbalne proszenie o przedmiot (Fidler, Philofsky, Hepburn, Rogers, 2005; Mundy, Kasari, 
Sigman, Ruskin, 1995) oraz odpowiadanie na inicjowanie podzielania uwagi przez dorosłego (Mundy i in., 1995). Ponadto z opóźnieniem pojawia się u nich odniesienie społeczne (Sorce, Emde, Frank, 1982). Zatem, pomimo ogólnej „towarzyskości” i tendencji do patrzenia na partnerów interakcji, u dzieci z zespołem Downa występują pewne deficyty, szczególnie w bardziej złożonych umiejętnościach uwagowych.

$\mathrm{W}$ badaniu z udziałem dzieci z zespołem Downa i dzieci typowo się rozwijających w podobnym wieku umysłowym (od 16 do 44 miesięcy) oceniano jakość zabawy, utrzymywanie zaangażowania w zabawę i jakość interakcji matka-dziecko (Cielinski, Vaughn, Seifer, Contreras, 1995). Badanie było podzielone na dwie części. W pierwszej części dzieci bawiły się same w obecności matki, która miała nie ingerować. Druga część polegała na zabawie wspólnej. Nie stwierdzono różnic międzygrupowych w jakości zabawy. Ponadto w obu grupach zabawa w interakcji z matką była na wyższym poziomie niż zabawa samodzielna. Dzieci z zespołem Downa były krócej zaangażowane w poszczególne części zabawy (częściej zmieniały aktywność) i krócej bawiły się zabawkami podczas epizodu z matką. Matki dzieci z zespołem Downa były bardziej intruzywne i dyrektywne niż matki dzieci rozwijających się typowo. Stwierdzono również pewne istotne korelacje w grupie dzieci z zespołem Downa: czas ich zaangażowania w zabawę przedmiotami w epizodzie z matką wiązał się z wyższą dyrektywnością matki i niższą częstością „inicjatyw społecznych” dziecka. Ponadto w grupie tej wyższa jakość zabawy w epizodzie z matką była związana z częstszymi zachowaniami wspomagającymi matki i większą liczbą intencjonalnych komunikatów dziecka. Powyższych zależności nie stwierdzono w grupie dzieci rozwijających się typowo, co sugeruje, że związek między zachowaniem dziecka i matki jest ściślejszy w diadach $\mathrm{z}$ dzieckiem $\mathrm{z}$ zespołem Downa. Dzieci z zespołem Downa mogą w większym stopniu polegać na partnerze interakcyjnym. Z kolei partner interakcyjny może mieć tendencję do nadmiernego ingerowania w zachowanie dziecka $\mathrm{z}$ zespołem Downa.

Podobnie jak w przypadku matek dzieci $\mathrm{z}$ autyzmem, w pracach powtarza się stwierdzenie, że matki dzieci z zespołem Downa zachowują się bardziej dyrektywnie niż matki dzieci rozwijających się typowo. Jednak, jak pokazały badania Ewy Pisuli (2003), reakcje dzieci z zespołem Downa na dyrektywne zachowania matek diametralnie różnią się od reakcji dzieci z autyzmem. Dzieci z zespołem Downa zwykle zachowują się ulegle - przyjmują inicjatywy matki, stąd zupełnie inny obraz interakcji, które z perspektywy obserwatora wydają się harmonijne (Pisula, 2003). W innym badaniu porównywano 
jakość zabawy dzieci z zespołem Downa i dobranych pod względem wieku umysłowego dzieci rozwijających się typowo (Venuti, de Falco, Esposito, Bornstein, 2009). Grupy nie różniły się poziomem dopasowania uczestników zabawy, mierzonym jako prawdopodobieństwo, że dziecko i matka bawią się tak samo (w zabawę na tym samy poziomie złożoności i tego samego rodzaju). Ponadto nie stwierdzono różnic w „zachowaniach wspierających” matek $\mathrm{z}$ obu grup.

Zwykle dyrektywność uważa się za niepożądaną cechę zachowań rodzicielskich, ponieważ ogranicza dziecku możliwość kształtowania przebiegu interakcji, a w dłuższej perspektywie może utrudniać dziecku rozwój pełnego potencjału rozwojowego ${ }^{21}$. Jednak według niektórych autorów w pewnych kontekstach zachowania dyrektywne mogą być korzystne dla dziecka. Cielinski i in. (1995) stwierdzają, że w ich badaniu (opisanym wcześniej), wyższa dyrektywność matki pozwalała dzieciom z zespołem Downa dłużej utrzymywać zaangażowanie $\mathrm{w}$ zabawę. $\mathrm{Z}$ kolei w badaniu podłużnym z udziałem dzieci urodzonych przedwcześnie, u których wystąpiły wylewy dokomorowe (dzieci te stanowią grupę wysokiego ryzyka wystąpienia zaburzeń rozwoju), stwierdzono pozytywne związki między dyrektywnością rodzica i osiągnięciami rozwojowymi dziecka (Moore, Saylor, Boyce, 1998). Kluczowe były jednak zarówno ilość, jak i jakość zachowań dyrektywnych. Większa ogólna liczba zachowań dyrektywnych matek podczas interakcji $\mathrm{z}$ dzieckiem w wieku 2 lat wiązała się z niższymi wynikami w testach funkcjonowania poznawczego dziecka w wieku 5,5 lat. Jednak wyższy poziom adekwatności (względem zachowania dziecka) i wyższa jakość zachowań dyrektywnych (łagodność, stosowanie sugestii) wiązały się z wyższymi wynikami dziecka w testach. Marfo (1990) argumentuje, że niesłusznie utożsamia się dyrektywność z brakiem wrażliwości i responsywności, a porównywanie zachowań matek dzieci typowo się rozwijających z matkami dzieci z niepełnosprawnościami pomija ocenę adaptacyjnej wartości tego typu zachowań $\mathrm{w}$ diadach z dziećmi o nietypowym rozwoju. Wydaje się, że odmienność opinii autorów po części mogą wynikać z różnego rozumienia i operacjonalizowania dyrektywności rodzicielskiej. Na przykład Lloyd i Masur (2014) w swoim badaniu rozróżniały zachowania dyrektywne intruzywne, responsywne i nieresponsywne, ale adekwatne. Autorki wyjaśniają, że zachowania

21 Należy jednak nadmienić, że istnieją różnice międzykulturowe w poziomie dyrektywności rodzicielskiej, który jest uznawany za adekwatny i korzystny ze względu na cele socjalizacji w danej kulturze (Sorkhabi, 2012). Przedstawiona teza dotyczy kultur zachodnich, indywidualistycznych. 
dyrektywne responsywne mogą być szczególnie pomocne, np. kiedy rodzic przekierowuje zachowanie dziecka, które zaprzestało aktywności zadaniowej, czy próbuje się oddalić.

Badania triad dziecko z zespołem Downa-matka-ojciec są bardzo nieliczne. W jednym $\mathrm{z}$ badań uczestniczyły triady, jednak porównywano funkcjonowanie diad dziecko-matka i dziecko-ojciec (de Falco, Venuti, Esposito, Bornstein, 2009). Oceniano jakość interakcji za pomocą Skal dostępności emocjonalnej (zob. rozdział 2.3). Jeśli chodzi o zachowanie rodziców, we wszystkich podskalach ich zachowanie oceniano co najmniej jako „wystarczająco dobre”. Nie stwierdzono również podwyższonej dyrektywności (w porównaniu ze średnią dla diad z dziećmi rozwijającymi się typowo). Jakość emocjonalna interakcji była podobna w interakcjach dziecko-matka i dziecko-ojciec - im wyższa dostępność emocjonalna w jednej diadzie, tym wyższa w drugiej. Autorzy (de Falco i in., 2009) wyjaśniają, że dostępność emocjonalna może być nie tyle właściwością osoby, co całego systemu rodzinnego. W większości badań interakcje dziecko z zespołem Downa-rodzic(e) są badane przez porównywanie ich z innymi grupami, najczęściej dziećmi $\mathrm{z}$ autyzmem, niepełnosprawnością intelektualną lub dziećmi typowo się rozwijającymi. Opisane powyżej badanie jest cenne nie tylko ze względu na włączenie w nie obojga rodziców, ale także dlatego, że skupiało się na tej specyficznej grupie i różnicach indywidualnych w jej obrębie.

Chociaż fenotyp behawioralny dzieci z zespołem Downa jest dobrze opisany, istnieją rozbieżności w opiniach co do tego, jaki styl interakcyjny rodzica jest optymalny ze względu na rozwój dziecka. Najbardziej dyskusyjne wydaje się zagadnienie dyrektywności rodzicielskiej. Brakuje nowych badań, które jasno pokazałyby, czy pewne rodzaje zachowań dyrektywnych (jakie? w jakich okolicznościach?) mogą wspierać rozwój dziecka z zespołem Downa. W jaki sposób dyrektywność rodzica wpływa na jego rozwój poznawczy, ale też rozwój autonomii, poczucia sprawstwa czy samooceny? Jak rodzic czuje się, kiedy stosuje dyrektywne zachowania, a jak, kiedy jest niedyrektywny wobec dziecka? Potrzebne są również badania, które opisywałyby zróżnicowanie pod względem jakości interakcji wśród diad i triad z dzieckiem z zespołem Downa, ich uwarunkowań i konsekwencji dla funkcjonowania dzieci i rodziców. 


\subsection{Dzieci z niepełnosprawnością intelektualną}

Niniejszy rozdział dotyczy dzieci, których niepełnosprawność intelektualna nie jest związana z zespołami zaburzeń o znanym podłożu genetycznym (zespół Downa, zespół Pradera-Williego, zespół Williamsa). Dzieci te stanowią zróżnicowaną grupę ze względu na stopień obniżenia zdolności intelektualnych, nasilenie trudności w codziennym funkcjonowaniu i kompetencje. Niepełnosprawność intelektualna współwystępuje z szeregiem zaburzeń i niepożądanych zachowań, takich jak samouszkodzenia, tiki, zachowania agresywne i destrukcyjne, zaburzenia uwagi, zaburzenia lękowe i depresyjne oraz zaburzenia przystosowania (Tylenda, Barrett, Sachs III, 2014). U około 50\% młodych osób z niepełnosprawnością intelektualną współwystępują problemy emocjonalne lub behawioralne (Dekker, Koot, Ende, Verhulst, 2002). Natomiast u 25\% dzieci i młodych osób w wieku od 7 do 20 lat z niepełnosprawnością intelektualną występują zespół nadpobudliwości psychoruchowej z deficytem uwagi, zaburzenia opozycyjno-buntownicze lub zaburzenia zachowania - zob. dalej (Dekker, Koot, 2003). Rodzice dzieci niepełnosprawnych intelektualnie mają podwyższony poziom stresu rodzicielskiego w porównaniu $\mathrm{z}$ rodzicami dzieci rozwijających się typowo, przy czym nasilenie tego stresu jest większe, gdy dziecko ma więcej problemów z funkcjonowaniem i zachowaniem (Baker, Blacher, Crnic, Edelbrock, 2002; Hassall, Rose, McDonald, 2005). Rodzice ci mają również podwyższone wyniki w Skali depresji Becka (Olsson, Hwang, 2001). Oznacza to, że interakcje dziecko-rodzic w tej grupie osób są obciążone - mogą stanowić wyzwanie tak dla dzieci, jak i dla rodziców.

Cechą interakcji dziecko z niepełnosprawnością intelektualną-rodzic jest większa zależność dziecka od zachowania rodzica w porównaniu z dziećmi rozwijającymi się typowo (Tylenda i in., 2014). Dzieci niepełnosprawne intelektualnie mają obniżone względem norm dla danego wieku zdolności poznawania świata społecznego i fizycznego oraz interakcji z nimi wynikające z opóźnień i nieprawidłowości w rozwoju percepcji, pamięci i uczenia się, motoryki i koordynacji. W tym kontekście zależność dziecka oznacza większą potrzebę nadawania ram (tworzenia rusztowania) przez partnera interakcji.

Przegląd literatury wykonany na potrzeby tej książki ujawnił ważny problem metodologiczny w badaniach diad $\mathrm{z}$ dzieckiem $\mathrm{z}$ niepełnosprawnością intelektualną. Mianowicie badane próby często są heterogeniczne - $\mathrm{w}$ grupie dzieci z niepełnosprawnością intelektualną często znajdują się dzieci 
z porażeniem mózgowym, zaburzeniami drgawkowymi, zespołami genetycznymi oraz niepełnosprawnością intelektualną o nieustalonym podłożu (zob. przegląd w: Childress, 2010). W takich badaniach trudno zidentyfikować właściwości interakcji specyficzne dla podgrup. Próbę ustalenia takich właściwości dla diad z dziećmi z zespołem Downa, opóźnieniem rozwoju o niezidentyfikowanej etiologii, ASD, porażeniem mózgowym i dziećmi typowo się rozwijającymi podjęli Blacher, Baker i Kaladjian (2013). Ogólnie stwierdzono wyższy poziom zachowań rodzicielskich określanych jako negatywne we wszystkich trzech grupach $\mathrm{z}$ dziećmi z zaburzeniami rozwoju w porównaniu $\mathrm{z}$ dziećmi rozwijającymi się typowo. W grupach z zaburzeniami rozwoju poza wyższym poziomem pozytywnych zachowań u rodziców dzieci z zespołem Downa, nie stwierdzono różnic specyficznych dla określonych niepełnosprawności, jednak wnioskowanie było utrudnione ze względu na niewielką liczbę osób badanych.

Podobnie jak przypadku diad z dziećmi z ASD czy zespołem Downa, dziecko i rodzic mogą wymagać wsparcia w nawiązywaniu i utrzymywaniu satysfakcjonujących interakcji.

W pracach dotyczących interwencji wspierających rozwój dzieci z niepełnosprawnością intelektualną dominuje pogląd, że niezbędnym ich elementem musi być praca nad jakością interakcji rodzic-dziecko (np. Guralnick, 2017). Aspektem zachowania rodziców, który prawdopodobnie ma kluczową rolę dla zmiany terapeutycznej, jest responsywność (Mahoney, Boyce, Fewell, Spiker, Wheeden, 1998). Jest to obszar pracy w większości terapii skoncentrowanych na interakcjach rodzic-dziecko. Ponadto jeżeli u dziecka występują nasilone objawy eksternalizacyjne, skuteczna jest dyrektywna, behawioralna metoda oparta na podręczniku, Parent-Child Interaction Training (PCIT; Bagner, Eyberg, 2007; Ros, Hernandez, Graziano, Bagner, 2016). Narzędziem, które od stosunkowo niedawna wprowadza się do pracy z rodzicami dzieci z niepełnosprawnością intelektualną, jest trening uważności (mindfulness). Ta skuteczna metoda o szerokim zastosowaniu (zob. np. Creswell, 2017; Grossman, Niemann, Schmidt, Walach, 2004) może pomagać im w radzeniu sobie ze stresem i podnosić ogólny dobrostan uczestników (Crnic, Neece, McIntyre, Blacher, Baker, 2017; Neece, 2014).

Ze względu na opisane wcześniej współwystępowanie niepełnosprawności intelektualnej z zaburzeniami emocjonalnymi i behawioralnymi, a także innymi niepełnosprawnościami i problemami zdrowotnymi, można spodziewać się dużego zróżnicowania w przebiegu i jakości interakcji w tej grupie dzieci i rodziców. Skuteczność interwencji wspierających interakcje 
tych diad jest ważnym czynnikiem, który może podnosić poziom funkcjonowania dziecka w różnych obszarach oraz jakość życia całej rodziny.

\subsection{Dzieci z zespołem nadpobudliwości psychoruchowej z deficytem uwagi}

Zespół nadpobudliwości psychoruchowej z deficytem uwagi (attention-deficity hyperactivity disorder, ADHD) jest diagnozowanym zwykle w okresie szkolnym zaburzeniem, którego objawy przez samą swą istotę wprowadzają chaos i dezorganizują przebieg zwykłych wydarzeń, np. zajęć lekcyjnych (jest to grupa zaburzeń określana jako disruptive disorders). Objawy ADHD można podzielić na trzy grupy: zachowania związane z nieuważnością (np. niezauważanie szczegółów, trudności z utrzymywaniem uwagi, trudności $\mathrm{z}$ wykonywaniem poleceń), zachowania związane z nadaktywnością (np. nadmierna ruchliwość, gadatliwość) oraz zachowania związane z impulsywnością (np. udzielanie odpowiedzi na pytania i działanie bez zastanowienia, przerywanie innym, niecierpliwość; Campbell, Halperin, Sonuga-Berke, 2014).

Znany jest szereg neurobiologicznych substratów ADHD obejmujących rozwój, anatomię i funkcjonowanie mózgu (Castellanos, Proal, 2012; Friedman, Rapoport, 2015; Kasparek, Theiner, Filova, 2015), mających źródła genetyczne (np. Klein i in., 2017) oraz związanych z wczesnym uszkodzeniem ośrodkowego układu nerwowego, np. w wyniku ekspozycji in utero na alkohol bądź dym tytoniowy (Mick, Biederman, Faraone, Sayer, Kleinman, 2002) czy przedwczesnego porodu (Bhutta, Cleves, Casey, Cradock, Anand, 2002). Jednak na przebieg tego zaburzenia i osiągnięcia rozwojowe dzieci z ADHD mają również znaczący wpływ czynniki środowiskowe, przede wszystkim środowisko rodzinne. Dlatego niezbędne jest kompleksowe leczenie: oddziaływania o charakterze psychoedukacyjnym, psychoterapeutycznym i treningowym, skierowane wobec dziecka i rodziców, u części dzieci połączone z terapią farmakologiczną (Namysłowska, Wolańczyk, 2010).

Jednym z głównych obszarów pracy terapeutycznej jest modyfikacja zachowania dziecka, rodziców i ich interakcji. Celem jest poprawa funkcjonowania dziecka w różnych sferach i kontekstach, a także całej rodziny, oraz zapobieganie rozwojowi zaburzeń współwystępujących, przede wszystkim zaburzeń zachowania. Mechanizmem rozwoju tych zaburzeń u dzieci z ADHD może być spirala negatywnych interakcji dziecko-opiekun. 
Z punktu widzenia rodzica interakcje z dzieckiem mającym ADHD mogą być trudne. Po pierwsze, dziecko z zaburzeniami uwagi może mieć poważne trudności z utrzymywaniem uwagi na partnerze interakcji oraz wspólnych działaniach. O ile dzieci z ADHD mogą przez dłuższy czas pozostawać zaangażowane w jedną aktywność, która wiąże się i ich zainteresowaniami (np. gry komputerowe), uczestniczenie w interakcjach wymagających dostosowania własnego zachowania do drugiej osoby bywa dla nich wyzwaniem. Po drugie, dziecko z ADHD preferuje aktywność ruchową oraz sytuacje, które dostarczają silnych bodźców i wielu wrażeń. Dla części dorosłych tak intensywne formy spędzania czasu z dzieckiem mogą być przeciążające fizyczne i psychiczne, szczególnie gdy ich czas trwania i częstość miałaby w pełni odpowiadać preferencjom dziecka. Dopasowanie do dziecka pod tym względem łatwiej przychodzi rodzicom, którzy sami mają wysoką potrzebę aktywności i poszukują wrażeń. Natomiast rozbieżność między potrzebami i preferencjami dziecka i rodziców może prowadzić do frustracji obu stron, a także konfliktów. Nasilają się one, kiedy wraz z wiekiem dziecka, jeszcze przed rozpoczęciem formalnej edukacji, coraz częściej oczekuje się od niego bycia "grzecznym”, tzn. przestrzegania norm społecznych i zachowywania w sposób, który dorośli uznają za właściwy. Kolejne wyzwania pojawiają się, kiedy wymagania szkolne nakładają na dziecko obowiązki wymagające kontroli uwagi i zachowania: wykonywanie poleceń, ograniczenie aktywności ruchowej, odrabianie zadań domowych, a także zdolności organizacyjnych. Nawet chcące spełnić różne oczekiwania dziecko doświadcza frustracji, ponieważ nie jest w stanie im podołać. $Z$ kolei rodziców frustruje niemożność wyegzekwowania od dziecka pożądanych zachowań. W wielu sytuacjach pojawiają się niezadowolenie, złość i smutek. Przy braku pomocy mogą pojawić się i nasilać zachowania opozycyjne i niszczycielskie, negatywizm, agresja dziecka względem rodziców i przemoc rodziców względem dziecka. Zapobieganiu i rozwiązywaniu tego typu problemów mogą służyć interwencje nakierowane na poprawę interakcji rodzic-dziecko.

Metodą o udowodnionej skuteczności w redukcji różnych objawów behawioralnych jest terapia interakcji rodzic-dziecko - Parent-Child Interaction Therapy (PCIT; Funderburk, Eyberg, 2011). Została ona opracowana specjalnie dla dzieci w wieku od 2 do 7 lat z ADHD, zaburzeniem opozycyjno-buntowniczym lub zaburzeniami zachowania i ich rodziców. Terapia ma dwie główne składowe - część dydaktyczną (wyjaśnienie znaczenia uczonych zachowań interakcyjnych i ich wpływu na zachowanie dziecka) i treningową (ćwiczenie zachowań w interakcji z dzieckiem w obecności terapeuty). 
Niedawna praca przeglądowa wskazała, że metoda może być skuteczna w redukowaniu objawów towarzyszących ADHD, np. zachowań trudnych, oraz podnoszeniu ogólnej jakości interakcji dziecko-rodzic (Vetter, 2018). Jednak ze względu na niedoskonałości metodologiczne uwzględnionych badań, takie jak niewielka liczebność prób czy brak randomizacji i pewne różnice między zastosowanymi programami terapeutycznymi (np. wynikającymi z dostosowania do różnych grup wiekowych [np. Barkley, 2002], w tym dzieci zbyt młodych, by posiadać formalną diagnozę ADHD), należy uznać te wyniki za wstępne.

Wagner i McNeil (2008) zwracają uwagę na dwa aspekty PCIT, które mogą oddziaływać na objawy specyficzne dla tego zaburzenia. Po pierwsze, sposób bawienia się z dzieckiem, jaki proponuje się rodzicowi, jest bardzo stymulujący. Po drugie, styl interakcyjny, którego uczy się rodzic (nadawanie struktury aktywności dziecka, naprzemienność, współdziałanie, uzyskiwanie posłuszeństwa bez stosowania zachowań intruzywnych, umiarkowana kontrola) pośrednio wpływa na rozwój umiejętności społecznych dziecka z ADHD, które może mieć trudności w kontaktach społecznych, szczególnie z rówieśnikami. Do tych dwóch efektów terapii należałoby dodać wpływ na relację rodzic-dziecko. Jak wyjaśniłam w rozdziale 1.3, relacja jest kształtowana przez interakcje. Wspólne bawienie się, satysfakcjonujące tak dla dziecka, jak i rodzica, oraz generalizacja pozytywnych wzorców interakcyjnych na inne codzienne sytuacje mogą chronić i naprawiać relację, której jakość jest zagrożona przez trudne zachowania i konflikty między dzieckiem i rodzicem. Jest to szczególnie ważne ze względu na ryzyko pogłębienia się zaburzeń relacji rodzic-dziecko przy braku interwencji terapeutycznej, co może prowadzić nawet do krzywdzenia dziecka (Brzozowska, Wzorek, 2011).

Istnieją zmodyfikowane wersje PCIT, jeszcze lepiej dostosowane do potrzeb dzieci z ADHD i ich rodziców. Jedna z nich, oprócz standardowych elementów PCIT, obejmuje psychoedukację dotyczącą zaburzenia. Ponadto zmieniono część treningową tak, aby rodzic nauczył się adekwatnie reagować na zachowania wynikające z trudności typowych dla dzieci z ADHD, m.in. krótki czas utrzymywania uwagi i nadmierną ruchliwość (McNeil, Hembree-Kigin, 2010). Natomiast trening behawioralno-poznawczy dla rodziców (Anastopoulos, Farley, 2003) obejmuje wypracowanie adekwatnych reakcji na niepożądane zachowania dziecka oraz wdrożenie procedury „czasu specjalnego" - niedyrektywnej zabawy z dzieckiem, która ma być źródłem pozytywnych doświadczeń interakcyjnych. Opis tego treningu w języku 
polskim Czytelnik znajdzie w zbiorze tekstów pod redakcją Kazdina i Weisza (2006). Ponadto istnieje wersja PCIT poszerzona o trening regulacji emocji (Chronis-Tuscano i in., 2016). Podczas terapii rodzic uczony jest strategii samoregulacji emocji (monitorowanie własnego stanu, relaksacja) oraz strategii, dzięki którym może wspierać dziecko w regulacji emocji (nazywanie emocji dziecka, proponowanie wybranej metody relaksacji). Pomocą w nauce jest $\mathrm{z}$ drzewo decyzyjne ułatwiające ustalenie, które zachowania będą najskuteczniejsze w danej sytuacji.

Wspieranie samoregulacji emocji rodzica, który ma dziecko z ADHD, jest uzasadnione z kilku powodów. Po pierwsze, ADHD występuje rodzinnie, zatem należy się spodziewać, że część rodziców dzieci z ADHD także może mieć objawy tego zaburzenia (o subklinicznym nasileniu bądź pełnoobjawowe ADHD; Weiss, Hechtman, Weiss, 2000). Ze względu na stosunkowo niedawne upowszechnienie wiedzy o tym zaburzeniu, wiele z tych osób może nie posiadać formalnej diagnozy, przez co w okresie dzieciństwa i dojrzewania nie uzyskało żadnej pomocy. Wspieranie tej grupy osób poprzez psychoedukację, a w przypadku dorosłych z nasilonymi objawami ADHD i zaburzeniami współwystępującymi - poprzez diagnostykę i leczenie, wydaje się niezbędne w toku interwencji, ponieważ objawy stanowią część wkładu rodzica w kształtowanie interakcji z dzieckiem. Wyniki badań pokazują, że nasilenie objawów ADHD u rodzica jest predyktorem poziomu odczuwanego przez nich stresu związanego $\mathrm{z}$ rodzicielstwem, niezależnie od nasilenia ocenianych przez nauczyciela problemów z zachowaniem dziecka (Theule, Wiener, Rogers, Marton, 2011). Objawy ADHD u rodziców mogą również obniżać skuteczność interwencji (Weiss i in., 2000). W badaniu skuteczności treningu rodzicielskiego zarówno nasilenie objawów ADHD u dziecka, jak i nasilenie tych objawów u rodzica, pozwalało przewidywać skuteczność interwencji - im cięższe objawy u dziecka i rodzica - tym mniejsza skuteczność interwencji (Sonuga-Barke, Daley, Thompson, 2002). U dzieci matek z najwyższym nasileniem objawów nie zaobserwowano żadnej poprawy.

Po drugie, opieka nad dzieckiem z zaburzeniem neurorozwojowym wiąże się z wieloma wyzwaniami i obciążeniami. Odzwierciedlają to wyniki badań - poziom stresu związanego $\mathrm{z}$ rodzicielstwem jest wyższy u rodziców dzieci z ADHD w porównaniu z rodzicami dzieci typowo się rozwijających oraz dzieci ze specyficznymi trudnościami w uczeniu się (Baker, McCal, 1995) oraz wyższy u rodziców dzieci z ADHD niż u rodziców dzieci z ASD (najwyższy poziom stresu związanego $\mathrm{z}$ rodzicielstwem stwierdzono $\mathrm{u}$ rodziców dzieci ze współwystępującymi ADHD i ASD; Miranda, Tárraga, 
Fernández, Colomer, Pastor, 2015) ${ }^{\mathbf{2 2}}$. Chroniczny stres odczuwany przez rodziców i trudne interakcje z dzieckiem wzajemnie się wzmacniają, dlatego ocena poziomu stresu rodzicielskiego powinna być elementem interwencji ukierunkowanych na poprawę jakości interakcji dziecko-rodzic. Ponadto wyniki badania $z$ udziałem nastolatków i ich matek wskazały, że jednym z mechanizmów wyjaśniających związek między objawami ADHD matki i zachowaniem dorastającego dziecka mogą być trudności matki w efektywnej regulacji własnych emocji, $\mathrm{w}$ tym nieakceptowanie negatywnych emocji, niedostępność strategii regulacyjnych oraz ograniczona zdolność do identyfikowania własnych emocji (Mazursky-Horowitz i in., 2015). Oznacza to, że przynajmniej część rodziców dzieci z ADHD potrzebuje nie tylko treningu radzenia sobie $\mathrm{z}$ emocjami pojawiającymi się $\mathrm{w}$ interakcjach $\mathrm{z}$ dzieckiem, ale także pracy nad ogólną zdolnością do regulacji emocji.

Jak wyjaśniają Weiss, Hechtman i Weiss (2000) - występowanie ADHD u rodzica dziecka z ADHD może pod pewnymi względami ułatwiać, a pod innymi utrudniać rodzicowi sprawowanie opieki nad dzieckiem. Z jednej strony, podobny poziom zapotrzebowania na stymulację może ułatwiać osiąganie synchronii interakcyjnej dzięki zbliżonym preferencjom co do tempa, intensywności i formy aktywności. Z drugiej strony, ze względu na wysoką reaktywność rodzica, objawy dziecka mogą być dla niego większym wyzwaniem niż dla osoby mniej reaktywnej, oraz zakłócać wykonywanie codziennych obowiązków, co już i tak jest trudne dla osoby z objawami nieuwagi. Kolejną kwestią jest postrzegane podobieństwo dziecka do siebie, które może ułatwiać rodzicowi nadawanie znaczenia jego zachowaniom. Jednak świadomość wpływu ADHD na codzienne funkcjonowanie rodzica, który sam ma objawy i doświadczył trudności z nimi związanych, może potęgować jego niepokój o rozwój dziecka i jego przyszłość.

Ze względu na profil neuropsychologiczny i behawioralny dziecka z ADHD, interakcje z nim mogą być trudne. Istnieją jednak skuteczne metody poprawiania ich jakości. Zwykle sama zmiana zachowań rodzica jest niewystarczająca - potrzebna jest również psychoedukacja i terapia dziecka, a w części przypadków farmakoterapia. Identyfikacja potrzeb i preferencji zarówno dziecka, jak i rodzica w odniesieniu do form aktywności może ułatwić kształtowanie takich interakcji zabawowych, które będą atrakcyjne

22 Autorzy jednej metaanalizy stwierdzili, że poziom stresu u rodziców dzieci z ADHD nie różni się od poziomu stresu u rodziców dzieci z innymi zaburzeniami (Theule, Wiener, Tannock, Jenkins, 2013). 
dla obu stron. Ponadto wypracowanie adekwatnych reakcji na objawy zakłócające codzienne funkcjonowanie służy rodzicowi jako narzędzie do radzenia sobie z trudnymi zachowaniami dziecka. Celem modyfikacji wzorców interakcji dziecko-rodzic jest łagodzenie objawów zaburzenia, wspieranie rozwoju dziecka w różnych sferach, ochrona i naprawa relacji dziecko-rodzic i zapobieganie rozwojowi zaburzeń współwystępujących u dziecka.

\subsection{Dzieci z zaburzeniami zachowania}

Zaburzenia zachowania (conduct disorders, CD) charakteryzują się przewlekłym występowaniem zachowań naruszających podstawowe prawa innych osób i niezgodnych z normami społecznymi, takich jak agresja czy niszczenie mienia oraz bardziej zawoalowane zachowania antyspołeczne i łamanie zasad, które nieleczone prowadzą u połowy dzieci i młodzieży do rozwoju osobowości antyspołecznej (Bierman, Sasser, 2014). U osób przed wystąpieniem zaburzeń zachowania stwierdza się zaburzenie opozycyjno-buntownicze, które objawia się zachowaniami opozycyjnymi, negatywizmem, mściwością, negatywnym nastrojem, podatnością na frustrację i labilnością emocjonalną, przy braku poważnych zachowań antyspołecznych (Bierman, Sasser, 2014). Wzorce nieprawidłowych zachowań z czasem utrwalają się, objawy ulegają nasileniu i prowadzą do coraz poważniejszych naruszeń norm społecznych (Dishion, Patterson, 2016). Podatność na wystąpienie zaburzeń zachowania ma częściowo podłoże genetyczne (fenotypowo objawiające się niskim podstawowym poziomem pobudzenia psychofizjologicznego) i jest większa u osób wychowujących się w rodzinach z niskim statusem socjoekonomicznym. Ponadto Granic i Patterson (2006) wyszczególniają dwa specyficzne wzorce reagowania na zachowanie dziecka, które sprzyjają rozwojowi $\mathrm{CD}$. W reakcji na niepożądane zachowania dziecka rodzice ulegają (np. kiedy dziecko zaczyna krzyczeć i kopać, dają mu to, czego chce, chociaż wcześniej nie zamierzali spełnić żądania dziecka) lub rezygnują z prób wywierania wpływu na zachowanie dziecka (wycofują się). Oznacza to, że interakcje dziecko-rodzic są jednym z mechanizmów rozwoju zaburzeń zachowania, a co za tym idzie - narzędziem zmiany terapeutycznej.

Patterson analizował rozwojowe źródła zachowań antyspołecznych u młodych osób (Patterson, Dishion, Bank, 1984). Według niego mają one początki w negatywnych interakcjach w obrębie rodziny (Patterson zamiennie używa słowa „wymiany”, exchanges). Wzorce negatywnych interakcji, które dominują w środowisku domowym, są generalizowane na 
inne konteksty, w szczególności szkołę i relacje rówieśnicze. Dziecko coraz bardziej ugruntowuje się w roli osoby agresywnej, „trudnej” i odrzucanej przez nauczycieli i tych rówieśników, którzy przeważnie przestrzegają norm. Dziecko czy nastolatek może wtedy poszukiwać akceptacji wśród osób zachowujących się podobnie, dołączając do grup, w których agresywne i przestępcze działania są nie tylko akceptowane, ale i nagradzane. W ten sposób utrwalany jest wzorzec zachowań antyspołecznych (Patterson i in., 1984).

Patterson zauważył, że zachowania w interakcjach rodzic-dziecko z zaburzeniami zachowania polegają de facto na wzajemnym wymierzaniu kar (Patterson, Reid, 1984). Chodzi tu o kary w rozumieniu teorii uczenia się, gdzie karą jest podanie awersyjnego bodźca (krytyka, groźba, krzyk, agresja fizyczna) - jest to tzw. kara pozytywna, bądź na zabraniu bodźca pozytywnego (niepodanie przysmaku, odebranie przedmiotu, przerwanie przyjemnej zabawy, zakłócanie wykonywania bieżącej czynności itp.) - jest to tzw. kara negatywna. Kary wymierza zarówno rodzic, jak i dziecko. Negatywną wymianę rozpoczyna zachowanie osoby, które drażni partnera interakcji. W odpowiedzi osoba ta wymierza karę, która z kolei wywołuje złość drugiej strony i jej reakcję w postaci kary. W ten sposób powstaje samopodtrzymujący się cykl negatywnych wymian, który zwykle kończy się dopiero, kiedy jedna ze stron wymierzy karę tak dotkliwą, że partner interakcji ustąpi. Ogół tego typu zachowań polegających na osiąganiu przez członków rodziny swoich celów poprzez stosowanie różnych nieprzyjemnych dla innych osób bodźców Patterson i współpracownicy nazywają wymuszeniowymi procesami rodzinnymi (coercive family processes; Dishion, Patterson, 2016). Wymuszanie uważa się za cechę charakterystyczną interakcji w rodzinach z dziećmi, u których rozwijają się później zaburzenia zachowania, począwszy od wymuszeniowych interakcji we wczesnym dzieciństwie, przez nasilanie się zachowań opozycyjnych u dziecka, po utrwalone wzorce agresywnych zachowań dziecka wobec rodziców i rodziców wobec dziecka oraz zachowań antyspołecznych dziecka, przejawianych w różnych kontekstach (zob. Dishion, Patterson, 2016; praca ta zawiera przegląd współczesnych badań potwierdzających trafność opisanego modelu).

Można wyobrazić sobie następującą sytuację. W autobusie znudzone podróżą dziecko próbuje wyjść z wózka, wstaje i szarpie się. Rodzic, który ma tendencję do szybkiego irytowania się w podobnych sytuacjach, chcąc, by dziecko pozostało w wózku, za złością przytrzymuje je i gani. Dziecko, teraz rozzłoszczone także zachowaniem rodzica, reaguje donośnym krzykiem. Rodzic, chcąc zakończyć tę wymianę, ostatecznie wyjmuje je z wózka. Fakt, 
że dziecko przestaje krzyczeć, jest dla rodzica wzmocnieniem negatywnym (usunięty zostaje bodziec awersyjny - krzyk dziecka). Natomiast zachowanie rodzica jest dla dziecka wzmocnieniem pozytywnym (nagrodą - zostało wyjęte z wózka). Sytuacja, w której osoba za pomocą danego zachowania uzyskuje to, czego chciała, zwiększa prawdopodobieństwo, że będzie się tak zachowywać w przyszłości.

W powyższej sekwencji zachowań można wyróżnić trzy fazy, które Patterson i Reid (1982) nazywają rozruchem (start up), kontratakiem (counterattack) i kontynuacją (continuance). Kiedy rodzic jest w stanie „neutralnym” (stoi w autobusie trzymając wózek), a dziecko zaczyna się szarpać, ma miejsce rozruch. Kiedy rodzic na zachowanie dziecka reaguje natychmiast w sposób awersyjny dla dziecka (przytrzymanie ze złością i ganiący komunikat werbalny), jest to kontratak. Kontynuacją jest donośny krzyk dziecka. Analogicznie, jeżeli rodzic nagle i bez wyjaśnienia przerywa zabawę dziecka, które bawi się, nie naruszając żadnych domowych zasad, dokonuje rozruchu. Dziecko, szczególnie jeżeli jest drażliwie, może kontratakować, rzucając się na ziemię i krzycząc. Rodzic kontynuuje wymuszeniową interakcję, jeżeli zaczyna grozić karą.

Nie we wszystkich rodzinach, w których część interakcji ma charakter wymuszeniowy, u dziecka pojawią się zaburzenia zachowania. Efekty rozwoju mają złożone źródła - wynikają z interakcji różnych czynników ryzyka i czynników chroniących przed wystąpieniem psychopatologii. Na przykład wyniki badania podłużnego, w którym monitorowano rozwój dużej grupy uczestników na przestrzeni 17 lat, wskazały, że u dzieci wychowujących się w rodzinach o niskim statusie socjoekonomicznym, które spędzały w żłobku lub przedszkolu od 30 do 40 godzin tygodniowo, lecz ta liczba godzin była osiągana stopniowo, miały niższy poziom zachowań agresywnych w okresie dojrzewania niż dzieci z ubogich rodzin, które w okresie przedszkolnym nie korzystały z opieki poza domem oraz tych dzieci, które od początku uczęszczania do żłobka lub przedszkola spędzały w nim wiele godzin dziennie (Orri i in., 2019). Zatem dzieci, które były w grupie podwyższonego ryzyka wystąpienia zaburzeń zachowania za względu na niski status socjoekonomiczny rodziny, uzyskiwały korzyści z opieki instytucjonalnej w pierwszych kilku latach życia, pod warunkiem, że miały możliwość stopniowego adaptowania się do zmiany formy opieki. Natomiast w innym badaniu stwierdzono, że u dzieci, u których występowało podwyższone ryzyko wystąpienia zaburzeń zachowania ze względu na czynnik teratogenny w okresie płodowym - palenie tytoniu przez matkę w ciąży, czynnikiem ochronnym były 
responsywne zachowania rodzicielskie (Wakschlag, Hans, 2002). W cytowanym badaniu wykazano, że chłopcy (nie dziewczynki), których matki paliły w ciąży, ale zachowywały się w sposób responsywny w pierwszych dwóch latach życia dziecka (łagodnie się z nim obchodziły, szybko reagowały, kiedy się denerwowało lub komunikowało potrzeby, wykazywały zainteresowanie aktywnością dziecka, dostosowały do niego tempo zachowania), rzadziej mieli diagnozowane zaburzenia w wieku 10 lat niż synowie palących w ciąży matek, które były mało responsywne. Wyniki te są również kolejnym dowodem na to, że responsywność rodzica sprzyja prawidłowemu rozwojowi społeczno-emocjonalnemu dziecka.

Chociaż model Pattersona opisuje, jakie zachowania składają się na wzorce interakcji wymuszeniowych, nie odwołuje się on do potrzeb leżących u podłoża tych zachowań. Badania takie jak opisane wcześniej (Wakschlag, Hans, 2002) są ważne, ponieważ przypominają, że zachowanie jest wyrazem procesów psychicznych osoby. Zatem nawet jeżeli w badaniach czy praktycznych zastosowaniach psychologii zajmujemy się obserwacją zachowania i jego zmianą, nie możemy zapominać leżących u jego podłoża procesów. Bez takiej refleksji istnieje ryzyko uprzedmiotowienia osób oraz pominięcia w badaniach naukowych, diagnozie i terapii wielu czynników, które wpływają na zachowanie osób.

Opisana w podrozdziale dotyczącym ADHD terapia interakcji rodzicdziecko PCIT ma udowodnioną skuteczność w redukowaniu objawów zaburzeń zachowania u dzieci (Brinkmeyer, Eyberg, 2006; Nixon, 2001; Zisser, Eyberg, 2010). W randomizowanym badaniu klinicznym przeprowadzonym w Norwegii porównano skuteczność PCIT z metodami zwykle stosowanymi w norweskich poradniach (najczęściej stosowana była terapia indywidualna dziecka i poradnictwo dla rodziców, a rzadziej terapia zabawowa i terapia rodzinna; Bjørseth, Wichstrøm, 2016). PCIT okazała się bardziej skuteczna - stwierdzono większy wzrost umiejętności rodzicielskich oraz spadek nasilenia objawów u dzieci. Wydaje się, że w przypadku dzieci z zaburzeniami zachowania, u których niszczycielskie, agresywne zachowania są nasilone, najpilniejszym celem terapeutycznym jest podniesienie umiejętności rodzica w sprawowaniu skutecznej i nieagresywnej kontroli nad zachowaniem dziecka. PCIT me ponadto pomóc rodzicowi i dziecku tworzyć pozytywne interakcje, pozwalające doświadczyć przyjemności z bycia razem. Długoterminowym celem treningu wrażliwości rodzicielskiej jest poprawa jakości przywiązania. 
Dzieci z zaburzeniami zachowania są trudnymi partnerami interakcyjnymi ze względu na ich negatywizm i opozycyjność, drażliwość, labilność emocjonalną i zachowania agresywne. Natomiast z punktu widzenia dziecka łatwo wpadający w złość, intruzywny, nadmiernie karzący lub wycofany rodzic nie pozwala współtworzyć pozytywnych, satysfakcjonujących interakcji. Programy terapeutyczne o udowodnionej skuteczności skupiają się na zmianie zachowania dziecka poprzez modyfikację zachowania rodzica. Wraz z poprawą jakości interakcji następuje także zmiana reprezentacji dziecka w umyśle rodzica, reprezentacji rodzica w umyśle dziecka oraz wzajemnej reprezentacji relacji (w terminach teorii przywiązania: wewnętrznych roboczych modeli przywiązania). Ważne jest, aby w pracy skoncentrowanej na modyfikacji zachowania uwzględniać refleksję nad źródłami zachowania: potrzebami, emocjami i motywacjami, przekonaniami, kompetencjami poznawczymi, społecznymi i samoregulacyjnymi oraz szerokim kontekstem rozwoju osób. 


\section{ZAKOŃCZENIE}

Celem tej książki było przedstawienie analizy interakcji rodzic-dziecko - jej podstawowych właściwości i zastosowań oraz zaproponowanie schematu analizy materiału obserwacyjnego. Jest to jednak tylko namiastka informacji o tym szeroko stosowanym w badaniach, jak i w różnych kontekstach klinicznych (diagnozie, poradnictwie, terapii) narzędziu, w ramach którego wyodrębnić można dwa główne podejścia - mikro- i makroanalizę, oraz szereg konstruktów i wiele schematów oceny interakcji.

Interakcje są kluczowe w rozwoju dziecka, ale także w rozwoju osób, które sprawują nad nim opiekę. W tej książce akcent położono na dziecko, co wiązało się z określaniem diady jako dziecko-rodzic, a nie rodzic-dziecko, chociaż to drugie dominuje w literaturze. $Z$ pewnością warto byłoby poświęcić również uwagę punktowi widzenia rodziców, w tym grupom rodziców, którzy doświadczają trudności psychicznych.

Poza zakresem tej książki znajdują się zagadnienia analizy danych ilościowych w badaniach. Należy jednak nadmienić, że rozwijane są nowoczesne narzędzia pozwalające analizować dynamikę interakcji dziecko-rodzic (przeglądy w: DiDonato, England, Martin, Amazeen, 2013; Gates, Liu, 2016), które dają badaczom możliwość lepszego zrozumienia obserwowanych interakcji, zachodzących procesów i potencjalnych obszarów zmiany zachowania.

Analiza interakcji to narzędzie bardzo elastyczne. Zarówno badacze, jak i klinicyści mogą dostosowywać ją do potrzeb swojej działalności. Jednak, aby móc nazwać ją narzędziem naukowym i stosować w badaniach, niezbędne jest przestrzeganie tego samego rygoru metodologicznego, co przy stosowaniu innych narzędzi badawczych. W zastosowaniu klinicznym konieczne jest bazowanie na uznanej i sprawdzonej empirycznie teorii, a sam proces analizy musi przebiegać według ustalonego schematu. Ważne, aby mieć świadomość praw osób, które są obserwowane i obowiązków, jakie wobec nich ma badacz czy klinicysta. Szczególnie wysokie standardy obowiązują psychologów i dotyczą wszystkich etapów pracy - od planowania, przez zbieranie danych obserwacyjnych i ich analizę po udzielanie informacji zwrotnych bądź publikację wyników badań. Pogłębione rozważania na ten temat Czytelnik znajdzie w pracach pod redakcją Brzezińskiej i Toeplitz (2007) oraz Brzezińskiego, Chyrowicz, Toeplitz i Toeplitz-Winiewskiej (2019). 


\section{BIBLIOGRAFIA}

Aarts, M. (2000). Marte Meo: Basic manual. Harderwijk: Aarts Production. Abney, D. H., Smith, L. B., Yu, C. (2017). It's time: Quantifying the relevant timescales for joint attention. Proceedings of the 39th Annual Meeting of the Cognitive Science Society, 1489-1494. Pobrane z: https://cogsci.mindmodeling.org/2017/papers/0293/paper0293.pdf

Adamson, L. B., Bakeman, R., Deckner, D. F. (2004). The development of symbol-infused joint engagement. Child Development, 75(4), 1171-1187. https://doi.org/10.1111/j.1467-8624.2004.00732.x

Adamson, L. B., Bakeman, R., Deckner, D. F., Nelson, P. B. (2012). Rating parent-child interactions: Joint engagement, communication dynamics, and shared topics in autism, Down syndrome, and typical development. Journal of Autism and Developmental Disorders, 42(12), 2622 2635. https://doi.org/10.1007/s10803-012-1520-1

Adamson, L. B., Frick, J. E. (2003). The still face: A history of a shared experimental paradigm. Infancy, 4(4), 451-473. https://doi.org/10.1207/ S15327078IN0404_01

Ahmadi, N., Chaudhry, S., Olango, G., Molla, M. (2017). The relation of parent-child interaction therapy (PCIT) in well-being of young children with attention-deficit/hyperactivity disorder (ADHD) and oppositional defiant disorder. Journal of the American Academy of Child and Adolescent Psychiatry, 56(10), 218. https://doi.org/10.1016/j.jaac.2017.09.191

Ahun, M. N., Côté, S. M. (2019). Maternal depressive symptoms and early childhood cognitive development: A review of putative environmental mediators. Archives of Women's Mental Health, 22(1), 15-24. https://doi. org/10.1007/s00737-018-0870-x

Ainsworth, M. D. S. (1969). Maternal care scales. Niepublikowany manuskrypt. Pobrane z: http://www.psychology.sunysb.edu/attachment/ measures/content/ainsworth_scales.html

Ainsworth, M. D. S., Bell, S. M. (1970). Attachment, exploration, and separation: Illustrated by the behavior of one-year-olds in a strange situation. Child Development, 41(1), 49-67. https://doi.org/10.2307/1127388

Ainsworth, M. D. S., Bell, S. M., Stayton, D. J. (1971). Individual differences in strange situation behavior of one year olds. W: H. R. Schaffer (red.), 
The origins of human social relationships (s. 17-57). Londyn: Academic Press.

Ainsworth, M. D. S., Blehar, M. C., Waters, E., Wall, S. N. (1978/2015). Patterns of attachment: A psychological study of the strange situation. Nowy Jork-Londyn: Routledge.

Aldred, C., Green, J., Adams, C. (2004). A new social communication intervention for children with autism: Pilot randomised controlled treatment study suggesting effectiveness. Journal of Child Psychology and Psychiatry, 45(8), 1420-1430. https://doi.org/10.1111/j.1469-7610.2004.00338.x

Allison, C., Baron-Cohen, S., Wheelwright, S., Charman, T., Richler, J., Pasco, G., Brayne, C. (2008). The Q-CHAT (Quantitative CHecklist for Autism in Toddlers): A normally distributed quantitative measure of autistic traits at 18-24 months of age: Preliminary report. Journal of Autism and Developmental Disorders, 38(8), 1414-1425. https://doi.org/10.1007/ s10803-007-0509-7

Anastopoulos, A. D., Farley, S. E. (2003). A cognitive-behavioral training program for parents of children with attention-deficit/hyperactivity disorder. W: A. E. Kazdin, J. R. Weisz (red.), Evidence-based psychotherapies for children and adolescents (s. 187-203). Nowy Jork: The Guilford Press. Anderson-Yockel, J., Haynes, W. O. (1994). Joint book-reading strategies in working-class African American and White mother-toddler dyads. Journal of Speech, Language, and Hearing Research, 37(3), 583-593. https://doi.org/10.1044/jshr.3703.583

Aspland, H., Gardner, F. (2003). Observational measures of parent-child interaction: An introductory review. Child and Adolescent Mental Health, 8(3), 136-143. https://doi.org/10.1111/1475-3588.00061

Atkins-Burnett, S., Monahan, S., Tarullo, L., Xue, Y., Cavadel, E., Malone, L., Akers, L. (2015). Measuring the quality of caregiver-child interactions for infants and toddlers (Q-CCIIT) (appendices). Mathematica Policy Research. Pobrane z: https://www.mathematica-mpr.com/-/media/publications/pdfs/earlychildhood/q-cciit_report_appen.pdf

Atkinson, J., Braddick, O. (2012). Visual attention in the first years: Typical development and developmental disorders. Developmental Medicine and Child Neurology, 54, 589-595. https://doi.org/10.1111/j.14698749.2012.04294.x

Azak, S., Raeder, S. (2013). Trajectories of parenting behavior and maternal depression. Infant Behavior and Development, 36(3), 391-402. https:// doi.org/10.1016/j.infbeh.2013.03.004 
Babska, Z., Shugar, G. W. (1984). Idea dwupodmiotowości interakcji dorosły-dziecko w procesie wychowania w pierwszych latach życia. Roczniki Filozoficzne, 32(4), 17-48.

Bagner, D. M., Eyberg, S. M. (2007). Parent-child interaction therapy for disruptive behavior in children with mental retardation: A randomized controlled trial. Journal of Clinical Child and Adolescent Psychology, 36(3), 418-429. https://doi.org/10.1080/15374410701448448

Bahrick, L. E. (2010). Intermodal perception and selective attention to intersensory redundancy: Implications for typical social development and autism. W: G. Bremner, A. Fogel (red.), Blackwell handbook of infant development (s. 120-165). Padstow: Blackwell Publishers Ltd. https://doi. org/10.1002/9780470996348

Bahrick, L. E., Lickliter, R. (2000). Intersensory redundancy guides attentional selectivity and perceptual learning in infancy. Developmental Psychology, 36(2), 190-201. https://doi.org/10.1037/0012-1649.36.2.190

Bakeman, R., Adamson, L. B. (1984). Coordinating attention to people and objects in mother-infant and peer-infant interaction. Child Development, 55(4), 1278-1289. https://doi.org/10.2307/1129997

Baker, B. L., Blacher, J., Crnic, K. A., Edelbrock, C. (2002). Behavior problems and parenting stress in families of three-year-old children with and without developmental delays. American Journal on Mental Retardation, 107(6), 433-444. https://doi.org/10.1352/0895-8017(2002)107<0433:BPAPSI $>2.0 . \mathrm{CO} ; 2$

Baker, D. B., McCal, K. (1995). Parenting stress in parents of children with attention-deficit hyperactivity disorder and parents of children with learning disabilities. Journal of Child and Family Studies, 4(1), 57-68. https://doi.org/10.1007/BF02233954

Bandura, A. (1977/2007). Teoria społecznego uczenia się. Warszawa: Wydawnictwo Naukowe PWN.

Barkley, R. A. (2002). Psychosocial treatments for attention-deficit hyperactivity disorder in children. Journal of Clinical Psychiatry, 63(12), 36-43.

Baron-Cohen, S. (1991). Precursors to a theory of mind: Understanding attention in others. Natural Theories of Mind: Evolution, Development and Simulation of Everyday Mindreading. Cambridge: Basil Blackwell.

Baron-Cohen, S., Wheelwright, S., Jolliffe, A. T. (1997). Is there a „language of the eyes"? Evidence from normal adults, and adults with autism or Asperger syndrome. Visual Cognition, 4(3), 311-331. https://doi. org/10.1080/713756761 
Barrera, M. E., Maurer, D. (1981). The perception of facial expressions by the three-month-old. Child Development, 52(1), 203-206. https://doi. org/10.2307/1129231

Baudry, C., Tarabulsy, G. M., Atkinson, L., Pearson, J., St-Pierre, A. (2017). Intervention with adolescent mother-child dyads and cognitive development in early childhood: A meta-analysis. Prevention Science, 18(1), 116-130. https://doi.org/10.1007/s11121-016-0731-7

Bateson, G. (1972/2000). Steps to an ecology of mind: Collected essays in anthropology, psychiatry, evolution, and epistemology. Chicago: University of Chicago Press.

Beebe, B. (2006). Co-constructing mother-infant distress in face-to-face interactions: Contributions of microanalysis. Infant Observation, 9(2), 151-164. https://doi.org/10.1080/13698030600810409

Beebe, B. (2017). My journey in infant research and psychoanalysis: Microanalysis, a social microscope. W: S. Lord (red.), Moments of meeting in psychoanalysis (s. 13-44). Abingdon: Routledge.

Beebe, B., Gerstman, L. (1984). A method of defining „packages” of maternal stimulation and their functional significance for the infant with mother and stranger. International Journal of Behavioral Development, 7(4), 423-440. https://doi.org/10.1177/016502548400700403

Beebe, B., Jaffe, J., Markese, S., Buck, K., Chen, H., Cohen, P., Feldstein, S. (2010). The origins of 12-month attachment: A microanalysis of 4-month mother-infant interaction. Attachment and Human Development, 12(12), 3-141. https://doi.org/10.1080/14616730903338985

Beebe, B., Steele, M. (2013). How does microanalysis of mother-infant communication inform maternal sensitivity and infant attachment? Attachment \& Human Development, 15(5-6), 583-602. https://doi.org/10.1080 /14616734.2013.841050

Behrens, K. Y., Parker, A. C., Haltigan, J. D. (2011). Maternal sensitivity assessed during the Strange Situation Procedure predicts child's attachment quality and reunion behaviors. Infant Behavior and Development, 34(2), 378-381. https://doi.org/10.1016/j.infbeh.2011.02.007

Belsky, J., Jaffee, S. R., Sligo, J., Woodward, L., Silva, P. A. (2005). Intergenerational transmission of warm-sensitive-stimulating parenting: A prospective study of mothers and fathers of 3-year-olds. Child Development, 76(2), 384-396. https://doi.org/10.1111/j.1467-8624.2005.00852.x

Bentenuto, A., de Falco, S., Venuti, P. (2016). Mother-child play: A comparison of autism spectrum disorder, Down syndrome, and typical 
development. Frontiers in Psychology, 7, 1829. https://doi.org/10.3389/ fpsyg.2016.01829

Berger, J., Cunningham, C. (1986). Aspects of early social smiling by infants with Down's syndrome. Child: Care, Health and Development, 12(1), 1324. https://doi.org/10.1111/j.1365-2214.1986.tb00483.x

Berk, L. E., Spuhl, S. T. (1995). Maternal interaction, private speech, and task performance in preschool children. Early Childhood Research Quarterly, 10(2), 145-169. https://doi.org/10.1016/0885-2006(95)90001-2

Bernier, A., Calkins, S. D., Bell, M. A. (2016). Longitudinal associations between the quality of mother-infant interactions and brain development across infancy. Child Development, 87(4), 1159-1174. https://doi. org/10.1111/cdev.12518

Bhutta, A. T., Cleves, M. A., Casey, P. H., Cradock, M. M., Anand, K. J. (2002). Cognitive and behavioral outcomes of school-aged children who were born preterm: A meta-analysis. Journal of the American Medical Association, 288(6), 728-737. https://doi.org/10.1001/jama.288.6.728

Białek, A., Białecka-Pikul, M., Stępień-Nycz, M. (2014). The nature of childadult interaction. From turn-taking to understanding pointing and use of pointing gestures. Psychology of Language and Communication, 18(2), 87-105. https://doi.org/0.2478/plc-2014-0008

Biemans, H. (1990). Video home training: Theory method and organisation of SPIN. W: J. Kool (red.), International seminar for innovative institutions (s. 96-112). Ryswijk: Ministry of Welfare Health and Culture.

Bierman, K. L., Sasser, T. R. (2014). Conduct disorder. W: M. Lewis, K. D. Rudolph (red.), Handbook of developmental psychopathology (s. 467-485). Nowy Jork: Springer Science+Business Media. https://doi. org/10.1007/978-1-4614-9608-3

Biringen, Z. (2000). Emotional availability: Conceptualization and research findings. American Journal of Orthopsychiatry, 70(1), 104-114.

Biringen, Z., Derscheid, D., Vliegen, N., Closson, L., Easterbrooks, M. A. (2014). Emotional availability (EA): Theoretical background, empirical research using the EA Scales, and clinical applications. Developmental Review, 34(2), 114-167. https://doi.org/10.1016/j.dr.2014.01.002

Biringen, Z., Easterbrooks, M. A. (2012). Emotional availability: Concept, research, and window on developmental psychopathology. Development and Psychopathology, 24(1), 1-8. https://doi.org10.1017/ S0954579411000617 
Biringen, Z., Robinson, J. L., Emde, R. N. (2000). Appendix B: The emotional availability scales (an abridged infancy/early childhood version). Attachment \& Human Development, 2(2), 256-270. https://doi. org/10.1080/14616730050085626

Bjørseth, Å., Wichstrøm, L. (2016). Effectiveness of parent-child interaction therapy (PCIT) in the treatment of young children's behavior problems. A randomized controlled study. PLoS ONE, 11(9), e0159845. https://doi. org/10.1371/journal.pone.0159845

Blacher, J., Baker, B. L., Kaladjian, A. (2013). Syndrome specificity and mother-child interactions: Examining positive and negative parenting across contexts and time. Journal of Autism and Developmental Disorders, 43(4), 761-774. https://doi.org/10.1007/s10803-012-1605-x

Blandon, A. Y., Calkins, S. D., Keane, S. P. (2010). Predicting emotional and social competence during early childhood from toddler risk and maternal behavior. Development and Psychopathology, 22(1), 119-132. https:// doi.org/10.1017/S0954579409990307

Blass, E. M., Lumeng, J., Patil, N. (2007). Influence of mutual gaze on human infant affect. W: R. Flom, K. Lee, D. Muir (red.), Gaze-following: Its development and significance (s. 113-141). Nowy Jork: Lawrence Erlbaum Associates Publishers. https://doi.org/10.4324/9781315093741

Bokus, B. (1984). Nawiazanie interakcji społecznych przez małe dziecko. Wrocław: Ossollineum.

Bornstein, M. H. (red.). (2002). Handbook of parenting. New Jersey: Lawrence Erlbaum Associates, Publishers. https://doi.org/10.4324/9780429401695

Bornstein, M. H., Tamis-LeMonda, C. S. (2008). Mother-infant interaction. W: G. Bremner, A. Fogel (red.), Blackwell handbook of infant development (s. 351-378). Padstow: Blackwell Publishers Ltd. https://doi. org/10.1002/9780470996348

Bornstein, M. H., Tamis-LeMonda, C. S., Hahn, C. S., Haynes, O. M. (2008). Maternal responsiveness to young children at three ages: Longitudinal analysis of a multidimensional, modular, and specific parenting construct. Developmental Psychology, 44(3), 867-874. https://doi. org/10.1037/0012-1649.44.3.867

Bosco, F. M., Bucciarelli, M., Bara, B. G. (2006). Recognition and repair of communicative failures: A developmental perspective. Journal of Pragmatics, 38(9), 1398-1429. https://doi.org/10.1016/j.pragma.2005.06.011

Bowlby, J. (1969/2007). Przywiązanie. Warszawa: Wydawnictwo Naukowe PWN. 
Brauer, J., Xiao, Y., Poulain, T., Friederici, A. D., Schirmer, A. (2016). Frequency of maternal touch predicts resting activity and connectivity of the developing social brain. Cerebral Cortex, 26(8), 3544-3552.

Brazelton, T. B., Cramer, B. G. (1990). The earliest relationship - Parents, infants, and the drama of attachment. Boston: A Merliyd Lawrence Book. Brenger, B., Mittelberg, I. (2015). Shakes, nods and tilts. Motion-capture data profiles of speakers and listeners head gestures. Proceedings of the 4th Gesture and Speech in Interaction (GESPIN) conference, 43-48.

Bretherton, I. (2013). Revisiting Mary Ainsworth's conceptualization and assessments of maternal sensitivity-insensitivity. Attachment \& Human Development, 15(5-6), 460-484.

Brinkmeyer, M. Y., Eyberg, S. M. (2006). Terapia interakcji rodzic-dziecko dla dzieci z zachowaniami opozycyjnymi. W: A. E. Kazdin, J. R. Weisz (red.), Psychoterapia dzieci i młodzieży. Metody oparte na dowodach (s. 210-228). Kraków: Wydawnictwo Uniwersytetu Jagiellońskiego.

Bronfenbrenner, U., Morris, P. A. (2006). The bioecological model of human development. W: R. M. Lerner, W. E. Damon (red.), Handbook of child psychology, t. 1: Theoretical models of human development (s. 793-828). Nowy Jork: John Wiley \& Sons Inc. https://doi. org/10.1002/9780470147658

Brooks, R., Meltzoff, A. N. (2005). The development of gaze following and its relation to language. Developmental Science, 8(6), 535-543. https:// doi.org/10.1111/j.1467-7687.2005.00445.x

Brzezińska, A. I. (2000). Społeczna psychologia rozwoju. Warszawa: Wydawnictwo Naukowe Scholar.

Brzezińska, A. I. (2015). Obserwacja dziecka w sytuacji zadaniowej - konstruowanie skali SOD-SZ. W: E. Filipiak (red.), Nauczanie rozwijające we wczesnej edukacji według Lwa S. Wygotskiego. Od teorii do zmiany w praktyce (s. 145-163). Bydgoszcz: Agencja Reklamowo-Wydawnicza ArtStudio.

Brzezińska, A. I., Appelt, K., Ziółkowska, B. (2011). Psychologia rozwoju człowieka. W: D. Doliński, J. Strelau (red.), Psychologia akademicka. Podręcznik, t. 2 (s. 122-133). Gdańsk: GWP.

Brzezińska, A. I., Toeplitz, Z. (red.). (2007). Problemy etyczne w badaniach $i$ interwencji psychologicznej wobec dzieci i młodzieży. Warszawa: Academica Wydawnictwo SWPS. 
Brzeziński, J. M., Chyrowicz, B., Toeplitz, Z., Toeplitz-Winiewska, M. (2019). Etyka zawodu psychologa: wydanie nowe. Warszawa: Wydawnictwo Naukowe PWN.

Brzeziński, J. M., Zakrzewska, M. (2011). Metodologia. Podstawy metodologiczne i statystyczne prowadzenia badań naukowych w psychologii. W: J. Strelau, D. Doliński (red.), Psychologia akademicka. Podręcznik, t. 1 (s. 175-302). Gdańsk: GWP.

Brzozowska, A., Wzorek, A. (2011). Zaburzenia więzi i krzywdzenie dzieci jako problem towarzyszący zaburzeniu hiperkinetycznemu (ADHD) i zaburzeniom zachowania. Psychiatria i Psychologia Kliniczna, 11(3), 189-193.

Bus, A. G., Leseman, P. P., Keultjes, P. (2000). Joint book reading across cultures: A comparison of Surinamese-Dutch, Turkish-Dutch, and Dutch parent-child dyads. Journal of Literacy Research, 32(1), 53-76. https:// doi.org/10.1080/10862960009548064

Butterworth, G. (2004). Joint visual attention in infancy. W: G. Bremner, A. Fogel (red.), Blackwell handbook of infant development (s. 213-240). Malden: Blackwell Publishing. https://doi.org/10.1002/9780470996348

Calkins, S. D., Hungerford, A., Dedmon, S. E. (2004). Mothers' interactions with temperamentally frustrated infants. Infant Mental Health Journal, 25(3), 219-239. https://doi.org/10.1002/imhj.20002

Campbell, S. B., Halperin, J. M., Sonuga-Berke, E. J. S (2014). A developmental perspective on Attention-Deficit/Hyperactivity Disorder (ADHD). W: M. Lewis, K. D. Rudolph (red.), Handbook of developmental psychopathology (s. 427-449). Nowy Jork: Springer Science \& Business Media. https://doi.org/10.1007/978-1-4614-9608-3

Campbell, S. B., Leezenbaum, N. B., Mahoney, A. S., Day, T. N., Schmidt, E. N. (2015). Social engagement with parents in 11-month-old siblings at high and low genetic risk for autism spectrum disorder. Autism, 19(8), 915-924. https://doi.org/10.1177/1362361314555146

Camras, L. A., Shutter, J. M. (2010). Emotional facial expressions in infancy. Emotion Review, 2(2), 120-129. https://doi.org/10.1177/1754073909352529

Carlson, S. M. (2005). Developmentally sensitive measures of executive function in preschool children. Developmental Neuropsychology, 28(2), 595-616. https://doi.org/10.1207/s15326942dn2802_3

Carneiro, C., Corboz-Warnery, A., Fivaz-Depeursinge, E. (2006). The prenatal Lausanne trilogue play: A new observational assessment tool of 
the prenatal co-parenting alliance. Infant Mental Health Journal, 27(2), 207-228. https://doi.org/10.1002/imhj.20089

Castellanos, F. X., Proal, E. (2012). Large-scale brain systems in ADHD: Beyond the prefrontal-striatal model. Trends in Cognitive Sciences, 16(1), 17-26. https://doi.org/10.1016/j.tics.2011.11.007

Cebula, K. R., Wishart, J. G. (2008). Social cognition in children with Down syndrome. International Review of Research in Mental Retardation, 35, 43-86. https://doi.org/10.1016/S0074-7750(07)35002-7

Cervantes, P. E., Matson, J. L., Goldin, R. L. (2016). Diagnosing ASD in very early childhood. W: J. Matson (red.), Handbook of assessment and diagnosis of autism spectrum disorders (s. 157-173). Nowy Jork: Springer. https://doi.org/10.1007/978-3-319-27171-2

Chapman, R. S., Hesketh, L. J. (2000). Behavioral phenotype of individuals with Down syndrome. Mental Retardation and Developmental Disabilities Research Reviews, 6(2), 84-95. https://doi.org/10.1002/10982779(2000)6:2<84::AID-MRDD2>3.0.CO;2-P

Charman, T., Baron-Cohen, S., Swettenham, J., Baird, G., Cox, A., Drew, A. (2000). Testing joint attention, imitation, and play as infancy precursors to language and theory of mind. Cognitive Development, 15(4), 481-498.

Childress, D. C. (2010). Play behaviors of parents and their young children with disabilities. Topics in Early Childhood Special Education, 31(2), 112120. https://doi.org/10.1177/0271121410390526

Christianson, A. L. H. C., Howson, C. P., Modell, B. (2006). March of dimes: Global report on birth defects, the hidden toll of dying and disabled children. Pobrane z: https://www.marchofdimes.org/global-report-on-birthdefects-the-hidden-toll-of-dying-and-disabled-children-full-report.pdf Chronis-Tuscano, A., Lewis-Morrarty, E., Woods, K. E., O’Brien, K. A., Mazursky-Horowitz, H., Thomas, S. R. (2016). Parent-child interaction therapy with emotion coaching for preschoolers with attention-deficit/ hyperactivity disorder. Cognitive and Behavioral Practice, 23(1), 62-78. https://doi.org/10.1016/j.cbpra.2014.11.001

Cicchetti, D., Sroufe, L. A. (1976). The relationship between affective and cognitive development in Down's syndrome infants. Child Development, 47, 920-929. https://doi.org/10.2307/1128427

Cielinski, K. L., Vaughn, B. E., Seifer, R., Contreras, J. (1995). Relations among sustained engagement during play, quality of play, and mother-child interaction in samples of children with Down syndrome and 
normally developing toddlers. Infant Behavior and Development, 18(2), 163-176. https://doi.org/10.1016/0163-6383(95)90046-2

Clowes, R. (2007). A self-regulation model of inner speech and its role in the organisation of human conscious experience. Journal of Consciousness Studies, 14(7), 59-71.

Cochet, H., Vauclair, J. (2010). Pointing gestures produced by toddlers from 15 to 30 months: Different functions, hand shapes and laterality patterns. Infant Behavior and Development, 33(4), 431-441. https://doi. org/10.1016/j.infbeh.2010.04.009

Cohn, J. F., Tronick, E. Z. (1983). Three-month-old infants' reaction to simulated maternal depression. Child Development, 54(1), 185-193. https:// doi.org/10.2307/1129876

Cohn, J. F., Tronick, E. Z. (1987). Mother-infant face-to-face interaction: The sequence of dyadic states at 3,6, and 9 months. Developmental Psychology, 23(1), 68-77. https://doi.org/10.1037/0012-1649.23.1.68

Colombo, J. (2001). The development of visual attention in infancy. Annual Review of Psychology, 52(1), 337-367. https://doi.org/10.1146/annurev. psych.52.1.337

Conty, L., George, N., Hietanen, J. K. (2016). Watching eyes effects: When others meet the self. Consciousness and Cognition, 45, 184-197. https:// doi.org/10.1016/j.concog.2016.08.016

Cooper, R. P., Aslin, R. N. (1990). Preference for infant-directed speech in the first month after birth. Child Development, 61(5), 1584-1595. https:// doi.org/10.1111/j.1467-8624.1990.tb02885.x

Corona, R., Lévy, F. (2015). Chemical olfactory signals and parenthood in mammals. Hormones and Behavior, 68, 77-90. https://doi.org/10.1016/j. yhbeh.2014.06.018

Courage, M. L., Adams, R. J. (1990). Visual acuity assessment from birth to three years using the acuity card procedure: Cross-sectional and longitudinal samples. Optometry and Vision Science: Official Publication of the American Academy of Optometry, 67(9), 713-718. https://doi. org/10.1097/00006324-199009000-00011

Creswell, J. D. (2017). Mindfulness interventions. Annual Review of Psychology, 68, 491-516. https://doi.org/10.1146/annurev-psych-042716-051139

Crnic, K. A., Neece, C. L., McIntyre, L. L., Blacher, J., Baker, B. L. (2017). Intellectual disability and developmental risk: Promoting intervention to improve child and family well-being. Child Development, 88(2), 436445. https://doi.org/10.1111/cdev.12740 
Csibra, G., Gergely, G. (2009). Natural pedagogy. Trends in Cognitive Sciences, 13(4), 148-153. https://doi.org/10.1016/j.tics.2009.01.005

Czownicka, A., Zalewska, M. (1988). O obserwacji psychologicznej: zasady wnioskowania diagnostycznego. W: M. Kościelska (red.), Studia z psychologii klinicznej dziecka (s. 33-48). Warszawa: WSiP.

Davis, M., Bilms, J., Suveg, C. (2017). In sync and in control: A meta-analysis of parent-child positive behavioral synchrony and youth self-regulation. Family Process, 56(4), 962-980. https://doi.org/10.1111/famp.12259

Davis, M., West, K., Bilms, J., Morelen, D., Suveg, C. (2018). A systematic review of parent-child synchrony: It is more than skin deep. Developmental Psychobiology, 60(6), 674-691. https://doi.org/10.1002/dev.21743

Davis, N. O., Carter, A. S. (2008). Parenting stress in mothers and fathers of toddlers with autism spectrum disorders: Associations with child characteristics. Journal of Autism and Developmental Disorders, 38(7), 1278-1291. https://doi.org/10.1007/s10803-007-0512-z

Dawson, G., Hill, D., Spencer, A., Galpert, L., Watson, L. (1990). Affective exchanges between young autistic children and their mothers. Journal of Abnormal Child Psychology, 18(3), 335-345. https://doi.org/10.1007/ BF00916569

de Barbaro, B. (red.). (1999). Wprowadzenie do systemowego rozumienia rodziny. Kraków: Wydawnictwo Uniwersytetu Jagiellońskiego.

de Barbaro, K., Johnson, C. M., Deák, G. O. (2013). Twelve-month „social revolution" emerges from mother-infant sensorimotor coordination: A longitudinal investigation. Human Development, 56(4), 223-248. https://doi.org/10.1159/000351313

de Campos, A. C., da Costa, C. S. N., Savelsbergh, G. J., Rocha, N. A. C. F. (2013). Infants with Down syndrome and their interactions with objects: Development of exploratory actions after reaching onset. Research in Developmental Disabilities, 34(6), 1906-1916. https://doi. org/10.1177/1362361314555146

de Falco, S., Venuti, P., Esposito, G., Bornstein, M. H. (2009). Motherchild and father-child emotional availability in families of children with Down syndrome. Parenting: Science and Practice, 9(3-4), 198-215. https://doi.org/10.1080/15295190902844381

DeCasper, A. J., Fifer, W. P. (1980). Of human bonding: Newborns prefer their mothers' voices. Science, 208(4448), 1174-1176. https://doi. org/10.1126/science.7375928 
Dekker, M. C., Koot, H. M. (2003). DSM-IV disorders in children with borderline to moderate intellectual disability. Prevalence and impact. Journal of the American Academy of Child \& Adolescent Psychiatry, 42(8), 915-922. https://doi.org/10.1097/01.CHI.0000046892.27264.1A

Dekker, M. C., Koot, H. M., Ende, J. V. D., Verhulst, F. C. (2002). Emotional and behavioral problems in children and adolescents with and without intellectual disability. Journal of Child Psychology and Psychiatry, 43(8), 1087-1098. https://doi.org/10.1111/1469-7610.00235

Della Longa, L., Gliga, T., Farroni, T. (2019). Tune to touch: Affective touch enhances learning of face identity in 4 -month-old infants. Developmental Cognitive Neuroscience, 35, 42-46. https://doi.org/10.1016/j. dcn.2017.11.002

DiDonato, M. D., England, D., Martin, C. L., Amazeen, P. G. (2013). Dynamical analyses for developmental science: A primer for intrigued scientists. Human Development, 56(1), 59-75. https://doi.org/10.1159/000342936

Dishion, T. J., Patterson, G. R. (2016). The development and ecology of antisocial behavior: Linking etiology, prevention, and treatment. W: D. Cicchetti (red.), Developmental psychopathology (s. 647-678). Nowy Jork: John Wiley \& Sons, Inc. https://doi.org/10.1002/9780470939406

Dragan, W. (2014). Temperament w pierwszym roku życia. Warszawa: Wydawnictwo naukowe Scholar.

Ekman, P. (1994). Strong evidence for universals in facial expressions: A reply to Russell's mistaken critique. Psychological Bulletin, 115, 268-287. https://doi.org/10.1037/0033-2909.115.2.268

Emde, R. N., Katz, E. L., Thorpe, J. K. (1978). Emotional expression in infancy: II. Early deviations in Down's syndrome. W: M. Lewis, L. A. Rosenblum (red.), The development of affect, t. 1 (s. 351-360). Boston: Springer. https://doi.org/10.1007/978-1-4684-2616-8

Erickson, M. F., Sroufe, L. A., Egeland, B. (1985). The relationship between quality of attachment and behavior problems in preschool in a highrisk sample. Monographs of the Society for Research in Child Development, 50(1-2), 147-166. https://doi.org/10.2307/3333831

Eyberg, S. M., Nelson, M. M., Duke, M., Boggs, S. R. (2004). Manual for the Dyadic Parent-Child Interaction Coding System. Pobrane z: https://www. incredibleyears.com/download/research/dpics-manual.pdf

Farroni, T., Johnson, M. H., Csibra, G. (2004). Mechanisms of eye gaze perception during infancy. Journal of Cognitive Neuroscience, 16(8), 1320 1326. https://doi.org/10.1162/0898929042304787 
Farroni, T., Johnson, M. H., Menon, E., Zulian, L., Faraguna, D., Csibra, G. (2005). Newborns' preference for face-relevant stimuli: Effects of contrast polarity. Proceedings of the National Academy of Sciences, 102(47), 17245-17250. https://doi.org/10.1073/pnas.0502205102

Favez, N., Frascarolo, F., Grimard, N. (2016). The PicNic game: Presentation of a situation of observation to assess family interactions. Infant Mental Health Journal, 37(3), 235-246. https://doi.org/10.1002/imhj.21561

Favez, N., Scaiola, C. L., Tissot, H., Darwiche, J., Frascarolo, F. (2011). The family alliance assessment scales: Steps toward validity and reliability of an observational assessment tool for early family interactions. Journal of Child and Family Studies, 20(1), 23-37. https://doi.org/10.1007/s10826010-9374-7

Feldman, R. (1998). Coding Interactive Behavior Manual. Niepublikowany podręcznik.

Feldman, R. (2003). Infant-mother and infant-father synchrony: The coregulation of positive arousal. Infant Mental Health Journal, 24(1), 1-23. https://doi.org/10.1002/imhj.10041

Feldman, R. (2007a). Maternal versus child risk and the development of parent-child and family relationships in five high-risk populations. Development and Psychopathology, 19(2), 293-312. https://doi. org/10.10170S0954579407070150

Feldman, R. (2007b). Parent-infant synchrony and the construction of shared timing; Physiological precursors, developmental outcomes, and risk conditions. Journal of Child Psychology and Psychiatry, 48(3-4), 329-354. https://doi.org/10.1111/j.1469-7610.2006.01701.x

Feldman, R. (2010). The relational basis of adolescent adjustment: Trajectories of mother-child interactive behaviors from infancy to adolescence shape adolescents' adaptation. Attachment \& Human Development, 12(12), 173-192. https://doi.org/10.1080/14616730903282472

Feldman, R. (2012). Parent-infant synchrony: A biobehavioral model of mutual influences in the formation of affiliative bonds. Monographs of the Society for Research in Child Development, 77(2), 42-51. https://doi. org/10.1111/j.1540-5834.2011.00660.x

Feldman, R. (2015). The adaptive human parental brain: Implications for children's social development. Trends in Neurosciences, 38(6), 387-399. https://doi.org/10.1016/j.tins.2015.04.004

Feldman, R., Eidelman, A. I., Sirota, L., Weller, A. (2002). Comparison of skin-to-skin (kangaroo) and traditional care: Parenting outcomes 
and preterm infant development. Pediatrics, 110(1), 16-26. https://doi. org/10.1542/peds.110.1.16

Feldman, R., Keren, M., Gross-Rozval, O., Tyano, S. (2004). Mother-child touch patterns in infant feeding disorders: Relation to maternal, child, and environmental factors. Journal of the American Academy of Child and Adolescent Psychiatry, 43(9), 1089-1097. https://doi.org/10.1097/01. chi.0000132810.98922.83

Feldman, R., Masalha, S., Nadam, R. (2001). Cultural perspective on work and family: Dual-earner Israeli Jewish and Arab families at the transition to parenthood. Journal of Family Psychology, 15(3), 492-509. https:// doi.org/10.1037/0893-3200.15.3.492

Fernald, A. (1985). Four-month-old infants prefer to listen to motherese. Infant Behavior and Development, 8(2), 181-195. https://doi.org/10.1016/ S0163-6383(85)80005-9

Fidler, D. J., Philofsky, A., Hepburn, S. L., Rogers, S. J. (2005). Nonverbal requesting and problem-solving by toddlers with Down syndrome. American Journal on Mental Retardation, 110(4), 312-322. https://doi. org/10.1352/0895-8017(2005)110[312:NRAPBT]2.0.CO;2

Field, T., Vega-Lahr, N., Scafidi, F., Goldstein, S. (1986). Effects of maternal unavailability on mother-infant interactions. Infant Behavior and Development, 9(4), 473-478. https://doi.org/10.1016/0163-6383(86)90019-6

Field, T. M., Woodson, R., Greenberg, R., Cohen, D. (1982). Discrimination and imitation of facial expression by neonates. Science, 218(4568), 179-181. https://doi.org/10.1126/science.7123230

Fish, M., Stifter, C. A., Belsky, J. (1993). Early patterns of mother-infant dyadic interaction: Infant, mother, and family demographic antecedents. Infant Behavior and Development, 16(1), 1-18. https://doi.org/10.1016/01636383(93)80025-4

Fivaz-Depeursinge, E. (2008). Infant's triangular communication in „two for one" versus "two against one” family triangles: Case illustrations. Infant Mental Health Journal, 29(3), 189-202. https://doi.org/10.1002/ imhj. 20174

Fivaz-Depeursinge, E., Corboz-Warnery, A. (1999). The primary triangle. A developmental systems view of mothers, fathers, and infants. Nowy Jork: Basic Books.

Fivaz-Depeursinge, E., Corboz-Warnery, A., Carneiro, C., Wasem, V. (2002). Coding manual for the GETCEF (Evaluation grid of the Lausanne Triadic Play). Niepublikowany manuskrypt. 
Fivaz-Depeursinge, E., Favez, N., Lavanchy, S., De Noni, S., Frascarolo, F. (2005). Four-month-olds make triangular bids to father and mother during trilogue play with still-face. Social Development, 14(2), 361-378. https://doi.org/10.1111/j.1467-9507.2005.00306.x

Forcada-Guex, M., Pierrehumbert, B., Borghini, A., Moessinger, A., MullerNix, C. (2006). Early dyadic patterns of mother-infant interactions and outcomes of prematurity at 18 months. Pediatrics, 118(1), 107-114. https:// doi.org/10.1542/peds.2005-1145

Franchak, J. M., Kretch, K. S., Adolph, K. E. (2018). See and be seen: Infantcaregiver social looking during locomotor free play. Developmental Science, 21(4), e12626. https://doi.org/10.1111/desc.12626

Franklin, B., Warlaumont, A. S., Messinger, D., Bene, E., Nathani Iyer, S., Lee, C. C., Oller, D. K. (2014). Effects of parental interaction on infant vocalization rate, variability and vocal type. Language Learning and Development, 10(3), 279-296. https://doi.org/10.1080/15475441.2013.849176

Frascarolo, F., Tissot, H., Favez, N. (2011). Observational situations of interactions in families of four and more people. Signal: Newsletter of the World Association for Infant Mental Health, 19(2), 1-6.

Freeman, S., Kasari, C. (2013). Parent-child interactions in autism: Characteristics of Play. Autism, 17(2), 147-161. https://doi.org/10.1177/1362361312469269

Friedman, L. A., Rapoport, J. L. (2015). Brain development in ADHD. Current Opinion in Neurobiology, 30, 106-111. https://doi.org/10.1016/j. conb.2014.11.007

Frydrychowicz, S. (1991). Na co w procesie interakcji komunikacyjnej mogą sobie pozwolić dzieci, a na co nie powinny sobie pozwalać osoby dorosłe? Zeszyty Naukowe Wyższej Szkoły Pedagogicznej w Bydgoszczy. Studia Psychologiczne, 9, 31-42.

Funderburk, B. W., Eyberg, S. (2011). Parent-child interaction therapy. W: J. C. Norcross, G. R. VandenBos, D. K. Freedheim (red.), History of psychotherapy: Continuity and change (s. 415-420). Waszyngton: American Psychological Association. https://doi.org/10.1037/12353-000

Gadaire, D. M., Henrich, C. C., Finn-Stevenson, M. (2017). Longitudinal effects of parent-child interactions on children's social competence. Research on Social Work Practice, 27(7), 767-778. https://doi. org/10.1177/1049731516632592

Gaffan, E. A., Martins, C., Healy, S., Murray, L. (2010). Early social experience and individual differences in infants' joint attention. Social Development, 19(2), 369-393. https://doi.org/10.1111/j.1467-9507.2008.00533.x 
Gardner, F. (2000). Methodological issues in the direct observation of parent-child interaction: Do observational findings reflect the natural behavior of participants? Clinical Child and Family Psychology Review, 3(3), 185-198. https://doi.org/10.1023/A:1009503409699

Gartstein, M. A., Rothbart, M. K. (2003). Studying infant temperament via the revised infant behavior questionnaire. Infant Behavior and Development, 26(1), 64-86. https://doi.org/10.1016/S0163-6383(02)00169-8

Gates, K. M., Liu, S. (2016). Methods for quantifying patterns of dynamic interactions in dyads. Assessment, 23(4), 459-471. https://doi. org/10.1177/1073191116641508

Gergely, G., Koós, O., Watson, J. S. (2010). Contingent parental reactivity in early socio-emotional development. W: T. Fuchs, H. C. Sattel, P. Henningsen (red.), The embodied self: Dimensions, coherence and disorders (s. 141-169). Stuttgart: Schattauer GmbH.

Gibson, E. J. (1982). The concept of affordances in development: The renascence of functionalism. W: W. A. Collins (red.), The Minnesota symposia on child psychology, t. 15: The concept of development (s. 55-82). Nowy Jork: Psychology Press.

Gibson, E. J., Schmuckler, M. A. (1989). Going somewhere: An ecological and experimental approach to development of mobility. Ecological Psychology, 1(1), 3-25. https://doi.org/10.1207/s15326969eco0101_2

Gibson, E. J., Walk, R. D. (1960). The „visual cliff”. Scientific American, 202(4), 64-71. https://www.jstor.org/stable/24940447

Gibson, J. J. (1979/2014). The ecological approach to visual perception. Nowy Jork: Psychology Press. https://doi.org/10.4324/9781315740218

Ginn, N. C., Clionsky, L. N., Eyberg, S. M., Warner-Metzger, C., Abner, J. P. (2017). Child-directed interaction training for young children with autism spectrum disorders: Parent and child outcomes. Journal of Clinical Child and Adolescent Psychology, 46(1), 101-109. https://doi.org/10.1080 /15374416.2015.1015135

Golinkoff, R. M., Can, D. D., Soderstrom, M., Hirsh-Pasek, K. (2015). (Baby) talk to me: The social context of infant-directed speech and its effects on early language acquisition. Current Directions in Psychological Science, 24(5), 339-344. https://doi.org/10.1177/0963721415595345

Gomez, J. A., Carter, A. S., Forbes, D., Gray, S. A. (2018). Parental insightfulness and parenting behavior: A two-dimensional analysis of parent contributions to child cognitive outcomes. Attachment \& Human Development, 20(3), 255-271. https://doi.org/10.1080/14616734.2018.1446734 
Granic, I., Hollenstein, T. (2003). Dynamic systems methods for models of developmental psychopathology. Development and Psychopathology, 15(3), 641-669. https://doi.org/10.1017.S0954579403000324

Granic, I., Patterson, G. R. (2006). Toward a comprehensive model of antisocial development: A dynamic systems approach. Psychological Review, 113(1), 101-131. https://doi.org/10.1037/0033-295X.113.1.101

Gratier, M. (2003). Expressive timing and interactional synchrony between mothers and infants: Cultural similarities, cultural differences, and the immigration experience. Cognitive Development, 18(4), 533-554. https:// doi.org/10.1016/j.cogdev.2003.09.009

Gratier, M., Devouche, E., Guellai, B., Infanti, R., Yilmaz, E., Parlato-Oliveira, E. (2015). Early development of turn-taking in vocal interaction between mothers and infants. Frontiers in Psychology, 6, 1167. https:// doi.org/10.3389/978-2-88919-825-2

Green, J., Charman, T., McConachie, H., Aldred, C., Slonims, V., Howlin, P., Barrett, B. (2010). Parent-mediated communication-focused treatment in children with autism (PACT): A randomised controlled trial. The Lancet, 375(9732), 2152-2160. https://doi.org/10.1016/S0140-6736(10)60587-9

Green, J., Charman, T., Pickles, A., Wan, M. W., Elsabbagh, M., Slonims, V., ..., Johnson, M. H. (2015). Parent-mediated intervention versus no intervention for infants at high risk of autism: A parallel, single-blind, randomised trial. The Lancet Psychiatry, 2(2), 133-140. https://doi. org/10.1016/S2215-0366(14)00091-1

Green, J., Garg, S. (2018). Annual research review: The state of autism intervention science: Progress, target psychological and biological mechanisms and future prospects. Journal of Child Psychology and Psychiatry, 59(4), 424-443. https://doi.org/10.1111/jcpp.12892

Greenspan, S. I., Wieder, S. (2006). Infant and early childhood mental health: A comprehensive, developmental approach to assessment and intervention. Waszyngton-Londyn: American Psychiatric Publishing, Inc.

Greenwood, C. R., Schnitz, A. G., Irvin, D., Tsai, S. F., Carta, J. J. (2018). Automated language environment analysis: A research synthesis. American Journal of Speech-Language Pathology, 27(2), 853-867. https://doi. org/10.1044/2017_AJSLP-17-0033

Grieco, J., Pulsifer, M., Seligsohn, K., Skotko, B., Schwartz, A. (2015). Down syndrome: Cognitive and behavioral functioning across the lifespan. American Journal of Medical Genetics Part C: Seminars in Medical Genetics, 169(2), 135-149. https://doi.org/10.1002/ajmg.c.31439 
Grossman, P., Niemann, L., Schmidt, S., Walach, H. (2004). Mindfulness-based stress reduction and health benefits: A meta-analysis. Journal of Psychosomatic Research, 57, 35-43. https://doi.org/10.1016/S00223999(03)00573-7

Gueron-Sela, N., Camerota, M., Willoughby, M. T., Vernon-Feagans, L., Cox, M. J., Family Life Project Key Investigators. (2018). Maternal depressive symptoms, mother-child interactions, and children's executive function. Developmental Psychology, 54(1), 71-82. https://doi.org/10.1037/ dev0000389

Guralnick, M. J. (2017). Early intervention for children with intellectual disabilities: An update. Journal of Applied Research in Intellectual Disabilities, 30(2), 211-229. https://doi.org/10.1111/jar.12233

Hahn, L. J., Loveall, S. J., Savoy, M. T., Neumann, A. M., Ikuta, T. (2018). Joint attention in Down syndrome: A meta-analysis. Research in Developmental Disabilities, 78, 89-102. https://doi.org/10.1016/j.ridd.2018.03.013

Hall, W. C., Levin, L. L., Anderson, M. L. (2017). Language deprivation syndrome: A possible neurodevelopmental disorder with sociocultural origins. Social Psychiatry and Psychiatric Epidemiology, 52(6), 761-776. https://doi.org/10.1007/s00127-017-1351-7

Harker, C. M., Ibañez, L. V., Nguyen, T. P., Messinger, D. S., Stone, W. L. (2016). The effect of parenting style on social smiling in infants at high and low risk for ASD. Journal of Autism and Developmental Disorders, 46(7), 2399-2407. https://doi.org/10.1007/s10803-016-2772-y

Harrist, A. W., Waugh, R. M. (2002). Dyadic synchrony: Its structure and function in children's development. Developmental Review, 22(4), 555592. https://doi.org/10.1016/S0273-2297(02)00500-2

Hassall, R., Rose, J., McDonald, J. (2005). Parenting stress in mothers of children with an intellectual disability: The effects of parental cognitions in relation to child characteristics and family support. Journal of Intellectual Disability Research, 49(6), 405-418. https://doi.org/10.1111/j.13652788.2005.00673.x

Haviland, J. M., Lelwica, M. (1987). The induced affect response: 10-week-old infants' responses to three emotion expressions. Developmental Psychology, 23(1), 97-104. https://doi.org/10.1037/0012-1649.23.1.97

Hedenbro, M., Lidén, A. (2002). CPICS: Child and Parents' Interaction Coding System in dyads and triads. Acta Paediatrica, 91, 1-19. https://doi. org/10.1111/j.1651-2227.2002.tb00459.x 
Hedenbro, M., Rydelius, P. A. (2019). Children's abilities to communicate with both parents in infancy were related to their social competence at the age of 15. Acta Paediatrica, 108(1), 118-123. https://doi.org/10.1111/ apa.14430

Hepper, P. G., Scott, D., Shahidullah, S. (1993). Newborn and fetal response to maternal voice. Journal of Reproductive and Infant Psychology, 11(3), 147-153. https://doi.org/10.1080/02646839308403210

Hertenstein, M. J. (2002). Touch: Its communicative functions in infancy. Human Development, 45(2), 70-94. https://doi.org/10.1159/000048154 Heyes, C. (2016). Born pupils? Natural pedagogy and cultural pedagogy. Perspectives on Psychological Science, 11(2), 280-295. https://doi. org/10.1177/1745691615621276

Hietanen, J. K. (2018). Affective eye contact: An integrative review. Frontiers in Psychology, 9, 1587. https://doi.org/10.3389/fpsyg.2018.01587

Hillairet de Boisferon, A., Tift, A. H., Minar, N. J., Lewkowicz, D. J. (2017). Selective attention to a talker's mouth in infancy: Role of audiovisual temporal synchrony and linguistic experience. Developmental Science, 20(3), el2381. https://doi.org/10.1111/desc.12381

Hobson, J. A., Tarver, L., Beurkens, N., Hobson, R. P. (2016). The relation between severity of autism and caregiver-child interaction: A study in the context of relationship development intervention. Journal of Abnormal Child Psychology, 44(4), 745-755. https://doi.org/10.1007/s10802015-0067-y

Hodapp, R. M., Thornton-Wells, T. A., Dykens, E. M. (2009). Intellectual disabilities W: C. H. Zeanah, Jr. (red.), Handbook of infant mental health (s. 332-344). Nowy Jork: The Guilford Press.

Hoehl, S., Wahl, S., Pauen, S. (2014). Disentangling the effects of an adult model's eye gaze and head orientation on young infants' processing of a previously attended object. Infancy, 19(1), 53-64. https://doi. org/10.1111/infa.12035

Hornowska, E. (2001). Testy psychologiczne. Teoria i praktyka. Warszawa: Wydawnictwo Naukowe Scholar.

Hornowska, E., Brzezińska, A. I., Appelt, K., Kaliszewska-Czeremska, K. (2014). Rola środowiska $w$ rozwoju małego dziecka-metody badania. Warszawa: Wydawnictwo Naukowe Scholar.

Høivik, M. S., Lydersen, S., Drugli, M. B., Onsøien, R., Hansen, M. B., Berg-Nielsen, T. S. (2015). Video feedback compared to treatment as usual in families with parent-child interactions problems: A randomized 
controlled trial. Child and Adolescent Psychiatry and Mental Health, 9, 3. https://doi.org/10.1186/s13034-015-0036-9

Hunnius, S., Geuze, R. H. (2004). Developmental changes in visual scanning of dynamic faces and abstract stimuli in infants: A longitudinal study. Infancy, 6(2), 231-255. https://doi.org/10.1207/s15327078in0602_5

Izard, C. E. (1992). Basic emotions, relations among emotions, and emotion-cognition relations. Psychological Review, 99(3), 561-565. https:// doi.org/10.1037/0033-295X.99.3.561

Izard, C. E. (1994). Innate and universal facial expressions: Evidence from developmental and cross-cultural research. Psychological Bulletin, 115, 288-299. https://doi.org/10.1037/0033-2909.115.2.288

Izard, C. E., Dougherty, L. M., Hembree, E. A. (1983). A system for identifying affect expressions by holistic judgments (AFFEX). Delaware: Instructional Resources Center, University of Delaware.

Jaffe, J., Beebe, B., Feldstein, S., Crown, C. L., Jasnow, M. D., Rochat, P., Stern, D. N. (2001). Rhythms of dialogue in infancy: Coordinated timing in development. Monographs of the Society for Research in Child Development, 66(2), I-VIII, 1-132.

Jasnow, M., Feldstein, S. (1986). Adult-like temporal characteristics of mother-infant vocal interactions. Child Development, 57, 754-761. https://doi. org/10.2307/1130352

Johnson, M. H. (1990). Cortical maturation and the development of visual attention in early infancy. Journal of Cognitive Neuroscience, 2(2), 81-95. https://doi.org/10.1162/jocn.1990.2.2.81

Johnson, M. H. (2005). Subcortical face processing. Nature Reviews Neuroscience, 6(10), 766-774. https://doi.org/10.1038/nrn1766

Johnson, M. H. (1994). Visual attention and the control of eye movements in early infancy. W: C. Umilta, M. Moscovitch (red.), Attention and performance, $t$. XV: Conscious and nonconscious information processing (s. 291-310). Canscious: MIT Press.

Johnson, M. H., de Haan, M. (2018). Neurokognitywistyka rozwoju. Wprowadzenie. Gdańsk: Harmonia Universalis.

Johnson, M. H., Gliga, T., Jones, E., Charman, T. (2015). Annual research review: Infant development, autism, and ADHD-early pathways to emerging disorders. Journal of Child Psychology and Psychiatry, 56(3), 228-247. https://doi.org/10.1111/jcpp.12328

Johnson, M. H., Posner, M., Rothbart, M. K. (1991). Components of visual orienting in early infancy: Contingency learning, anticipatory looking, 
and disengaging. Journal of Cognitive Neuroscience, 3(4), 335-344. https://doi.org/10.1162/jocn.1991.3.4.335

Jones, E. J., Gliga, T., Bedford, R., Charman, T., Johnson, M. H. (2014). Developmental pathways to autism: A review of prospective studies of infants at risk. Neuroscience \& Biobehavioral Reviews, 39, 1-33. https://doi. org/10.1016/j.neubiorev.2013.12.001

Jones, E. J., Johnson, M. H. (2017). Early neurocognitive markers of developmental psychopathology. W: L. C. Centifanti, D. M. Williams (red.), The Wiley handbook of developmental psychopathology (s. 197-214). Hoboken: John Wiley \& Sons. https://doi.org/10.1002/9781118554470

Jones, W., Klin, A. (2013). Attention to eyes is present but in decline in 2-6-month-old infants later diagnosed with autism. Nature, 504(7480), 427-431. https://doi.org/10.1038/nature12715

Juffer, F., Bakermans-Kranenburg, M. J., van IJzendoorn, M. H. (red.). (2012). Promoting positive parenting: An attachment-based intervention. Nowy Jork-Londyn: Routledge. https://doi.org/10.4324/9780203809624 Juffer, F., Bakermans-Kranenburg, M. J., van IJzendoorn, M. H. (2017). Pairing attachment theory and social learning theory in video-feedback intervention to promote positive parenting. Current Opinion in Psychology, 15, 189-194. https://doi.org/10.1016/j.copsyc.2017.03.012

Justice, L. M., Jiang, H., Purtell, K. M., Schmeer, K., Boone, K., Bates, R., Salsberry, P. J. (2019). Conditions of poverty, parent-child interactions, and toddlers' early language skills in low-income families. Maternal and Child Health Journal, 23(7), 971-978. https://doi.org/10.1007/s10995-01802726-9

Kaderavek, J. N., Sulzby, E. (1998). Parent-child joint book reading. American Journal of Speech-Language Pathology, 7(1), 33-47. https://doi. org/10.1044/1058-0360.0701.33

Kasari, C., Gulsrud, A., Paparella, T., Hellemann, G., Berry, K. (2015). Randomized comparative efficacy study of parent-mediated interventions for toddlers with autism. Journal of Consulting and Clinical Psychology, 83(3), 554-563. https://doi.org/10.1037/a0039080

Kasari, C., Gulsrud, A. C., Wong, C., Kwon, S., Locke, J. (2010). Randomized controlled caregiver mediated joint engagement intervention for toddlers with autism. Journal of Autism and Developmental Disorders, 40(9), 1045-1056. https://doi.org/10.1007/s10803-010-0955-5 
Kasari, C., Mundy, P., Yirmiya, N., Sigman, M. (1990). Affect and attention in children with Down syndrome. American Journal of Mental Retardation, 95, 55-67.

Kasparek, T., Theiner, P., Filova, A. (2015). Neurobiology of ADHD from childhood to adulthood: Findings of imaging methods. Journal of Attention Disorders, 19(11), 931-943. https://doi.org/10.1177/1087054713505322

Kazdin, A. E., Weisz, J. R. (red.). (2006). Psychoterapia dzieci i młodzieży. Metody oparte na dowodach. Kraków: Wydawnictwo Uniwersytetu Jagiellońskiego.

Kennedy, H., Landor, M., Todd, L. (2010). Video Interaction Guidance as a method to promote secure attachment. Educational and Child Psychology, 27(3), 59-72.

Kielar-Turska, M. (2013). Językowa zewnętrzna i wewnętrzna kontrola działania. Psychologia Rozwojowa, 18(4), 47-61.

Kielar-Turska, M., Białecka-Pikul, M., Skórska, A. (2006). Rozwój zdolności mentalizacji. Z badań nad związkiem teorii umysłu, sprawności językowych i funkcji zarządzającej. Psychologia Rozwojowa, 11(2), 35-47.

Klein, M., Onnink, M., van Donkelaar, M., Wolfers, T., Harich, B., Shi, Y., Franke, B. (2017). Brain imaging genetics in ADHD and beyondmapping pathways from gene to disorder at different levels of complexity. Neuroscience \& Biobehavioral Reviews, 80, 115-155. https://doi. org/10.1016/j.neubiorev.2017.01.013

Krasnor, L. R., Pepler, D. J. (1980). The study of children's play: Some suggested future directions. New Directions for Child and Adolescent Development, 1980(9), 85-95. https://doi.org/10.1002/cd.23219800908

Kmita, G. (2005). Od obrazu do znaczenia. Wykorzystanie analizy interakcji w terapii małych dzieci i ich rodzin. W: M. Święcicka, M. Zalewska (red.), Problematyka kontaktu $w$ diagnozie i terapii dzieci. Zeszyty Sekcji Psychologii Klinicznej Dziecka Polskiego Towarzystwa Psychologicznego (Nr 3) (s. 59-72). Warszawa: Wydawnictwo Emu.

Kmita, G. (red.). (2007). Klasyfikacja diagnostyczna DC: 0-3R. Wydanie poprawione. Warszawa: Oficyna Wydawnicza Fundament.

Kmita, G. (2011). Obserwacja interakcji niemowlę - rodzice. Rola mikroanalizy zachowania. W: M. Święcicka (red.), Metody diagnozy w psychologii klinicznej dziecka i rodziny (s. 43-53). Warszawa: Wydawnictwo Paradygmat.

Kmita, G. (2013). Od zaciekawienia do zaangażowania. Warszawa: Wydawnictwa Uniwersytetu Warszawskiego. 
Kmita, G. (2018). Interakcje w triadzie matka-ojciec-dziecko w diagnozie i terapii dzieci urodzonych ze skrajnym wcześniactwem. Polskie Forum Psychologiczne, 23(3), 516-529. https://doi.org/10.14656/PFP20180303

Kmita, G., Kiepura, E., Majos, A. (2014). Paternal involvement and attention sharing in interactions of premature and full-term infants with fathers: A brief report. Psychology of Language and Communication, 18(3), 190203. https://doi.org/10.2478/plc-2014-0013

Kochanska, G., Boldt, L. J., Goffin, K. C. (2019). Early relational experience: A foundation for the unfolding dynamics of parent-child socialization. Child Development Perspectives, 13(1), 41-47. https://doi.org/10.1111/ cdep. 12308

Kodeks etyczno-zawodowy psychologa. (1994). Warszawa: Polskie Towarzystwo Psychologiczne.

Koulomzin, M., Beebe, B., Anderson, S., Jaffe, J., Feldstein, S., Crown, C. (2002). Infant gaze, head, face and self-touch at 4 months differentiate secure vs. avoidant attachment at 1 year: A microanalytic approach. Attachment and Human Development, 4(1), 3-24. https://doi. org/10.1080/14616730210123120

Kuroki, M. (2007). The effect of positive emotion on infants' gaze shift. Infant Behavior and Development, 30(4), 606-614. https://doi.org/10.1016/j. infbeh.2007.03.008

Lavanchy Scaiola, C., Favez, N., Tissot, H., Frascarolo, F. (2009). The Family Alliance Assessment Scales (FAAS), manuel de codage. Niepublikowany manuskrypt.

Lavelli, M., Fogel, A. (2005). Developmental changes in the relationship between the infant's attention and emotion during early face-to-face communication: The 2-month transition. Developmental Psychology, 41(1), 265-280. https://doi.org/10.1037/0012-1649.41.1.265

Lawn, J. E., Mwansa-Kambafwile, J., Horta, B. L., Barros, F. C., Cousens, S. (2010). „Kangaroo mother care” to prevent neonatal deaths due to preterm birth complications. International Journal of Epidemiology, 39, i144-i154. https://doi.org/10.1093/ije/dyq031

Lebowitz, E. R., Shic, F., Campbell, D., MacLeod, J., Silverman, W. K. (2015). Avoidance moderates the association between mothers' and children's fears: Findings from a novel motion-tracking behavioral assessment. Depression and Anxiety, 32(2), 91-98. https://doi.org/10.1002/da.22333

Leclère, C., Viaux, S., Avril, M., Achard, C., Chetouani, M., Missonnier, S., Cohen, D. (2014). Why synchrony matters during mother-child 
interactions: A systematic review. PLoS ONE, 9(12), e113571. https://doi. org/10.1371/journal.pone.0113571

Leerkes, E., Qu, J. (2017). The maternal (non) responsiveness questionnaire: Initial factor structure and validation. Infant and Child Development, 26(3), e1992. https://doi.org/10.1002/icd.1992

Legerstee, M. (2009). The role of dyadic communication in social cognitive development. Advances in Child Development and Behavior, 37, 1-53. https://doi.org/10.1016/S0065-2407(09)03701-X

Legerstee, M., Fisher, T. (2008). Coordinated attention, declarative and imperative pointing in infants with and without Down syndrome: Sharing experiences with adults and peers. First Language, 28(3), 281-311. https:// doi.org/10.1177/0142723708091045

Legerstee, M., Weintraub, J. (1997). The integration of person and object attention in infants with and without Down syndrome. Infant Behavior and Development, 20(1), 71-82. https://doi.org/10.1016/S01636383(97)90062-X

Lewkowicz, D. J., Hansen-Tift, A. M. (2012). Infants deploy selective attention to the mouth of a talking face when learning speech. Proceedings of the National Academy of Sciences, 109(5), 1431-1436. https://doi. org/10.1073/pnas.1114783109

Lien, J. J. J., Kanade, T., Cohn, J. F., Li, C. C. (2000). Detection, tracking, and classification of action units in facial expression. Robotics and Autonomous Systems, 31(3), 131-146. https://doi.org/10.1016/S09218890(99)00103-7

Lloyd, C. A., Masur, E. F. (2014). Infant behaviors influence mothers' provision of responsive and directive behaviors. Infant Behavior and Development, 37(3), 276-285. https://doi.org/10.1016/j.infbeh.2014.04.004

Lloyd-Fox, S., Blasi, A., Elwell, C. E. (2010). Illuminating the developing brain: The past, present and future of functional near infrared spectroscopy. Neuroscience and Biobehavioral Reviews, 34(3), 269-284. https:// doi.org/10.1016/j.neubiorev.2009.07.008

López Pérez, D., Leonardi, G., Niedźwiecka, A., Radkowska, A., Raczaszek-Leonardi, J., Tomalski, P. (2017). Combining recurrence analysis and automatic movement extraction from video recordings to study behavioural coupling in face-to-face parent-child interactions. Frontiers in Psychology, 8, 2228. https://doi.org/10.3389/fpsyg.2017.02228

Lotzin, A., Lu, X., Kriston, L., Schiborr, J., Musal, T., Romer, G., Ramsauer, B. (2015). Observational tools for measuring parent-infant interaction: 
A systematic review. Clinical Child and Family Psychology Review, 18(2), 99-132. https://doi.org10.1007/s10567-015-0180-z

Lubiewska, K. (2019). Przywiązanie w kontekście wrażliwości rodzicielskiej, socjalizacji oraz wpływów kulturowych. Warszawa: PWN.

MacDonald, K. (2009). Patient-clinician eye contact: Social neuroscience and art of clinical engagement. Postgraduate Medicine, 121(4), 136-144. https://doi.org/10.3810/pgm.2009.07.2039

MacLean, P. C., Rynes, K. N., Aragón, C., Caprihan, A., Phillips, J. P., Lowe, J. R. (2014). Mother-infant mutual eye gaze supports emotion regulation in infancy during the still-face paradigm. Infant Behavior and Development, 37(4), 512-522. https://doi.org/10.1016/j.infbeh.2014.06.008

Magill-Evans, J., Harrison, M. J. (2001). Parent-child interactions, parenting stress, and developmental outcomes at 4 years. Children's Health Care, 30(2), 135-150. https://doi.org/10.1207/S15326888CHC3002_4

Mahdhaoui, A., Chetouani, M., Cassel, R. S., Saint-Georges, C., Parlato, E., Laznik, M. C., Cohen, D. (2011). Computerized home video detection for motherese may help to study impaired interaction between infants who become autistic and their parents. International Journal of Methods in Psychiatric Research, 20(1), e6-el8. https://doi.org/10.1002/mpr.332

Mahoney, G., Boyce, G., Fewell, R. R., Spiker, D., Wheeden, C. A. (1998). The relationship of parent-child interaction to the effectiveness of early intervention services for at-risk children and children with disabilities. Topics in Early Childhood Special Education, 18(1), 5-17. https://doi. org/10.1177/027112149801800104

Marfo, K. (1990). Maternal directiveness in interactions with mentally handicapped children: An analytical commentary. Journal of Child Psychology and Psychiatry, 31(4), 531-549. https://doi.org/10.1111/j.1469-7610.1990. tb00796.x

Maroulis, A., Spink, A. J., Theuws, J. J. M., Oster, H. Buitelaar, J. (2017, sierpień). Sweet or sour. Validating Baby FaceReader to analyse infant responses to food. Poster na 12th Pangborn Sensory Science Symposium, Providence, USA.

Martin, N. G., Witherington, D. C., Edwards, A. (2008). The development of affect specificity in infants' use of emotion cues. Infancy, 13(5), 456-468. https://doi.org/10.1080/15250000802329370

Mason, G. M., Kirkpatrick, F., Schwade, J. A., Goldstein, M. H. (2018). The role of dyadic coordination in organizing visual attention in 5-monthold infants. Infancy, 24(2), 162-186. https://doi.org/10.1111/infa.12255 
Matson, J. L., Wilkins, J., González, M. (2008). Early identification and diagnosis in autism spectrum disorders in young children and infants: How early is too early? Research in Autism Spectrum Disorders, 2(1), 75-84. https://doi.org/10.1016/j.rasd.2007.03.002

Matsugu, M., Mori, K., Mitari, Y., Kaneda, Y. (2003). Subject independent facial expression recognition with robust face detection using a convolutional neural network. Neural Networks, 16(5-6), 555-559. https://doi. org/10.1016/S0893-6080(03)00115-1

Maurer, D., Maurer, C. (1988). The world of the newborn. Nowy Jork: Basic Books.

Mazursky-Horowitz, H., Felton, J. W., MacPherson, L., Ehrlich, K. B., Cassidy, J., Lejuez, C. W., Chronis-Tuscano, A. (2015). Maternal emotion regulation mediates the association between adult attention-deficit/hyperactivity disorder symptoms and parenting. Journal of Abnormal Child Psychology, 43(1), 121-131. https://doi.org/10.1007/s10802-014-9894-5

McConachie, H., Randle, V., Hammal, D., Le Couteur, A. (2005). A controlled trial of a training course for parents of children with suspected autism spectrum disorder. The Journal of Pediatrics, 147(3), 335-340. https://doi.org/10.1016/j.jpeds.2005.03.056

McGillion, M. L., Herbert, J. S., Pine, J. M., Keren-Portnoy, T., Vihman, M. M., Matthews, D. E. (2013). Supporting early vocabulary development: What sort of responsiveness matters? IEEE Transactions on Autonomous Mental Development, 5(3), 240-248. https://doi.org/10.1109/ TAMD.2013.2275949

McHale, J. P., Favez, N., Fivaz-Depeursinge, E. (2018). The Lausanne Trilogue Play paradigm: Breaking discoveries in family process and therapy. Journal of Child and Family Studies, 27(10), 3063-3072. https://doi. org/10.1007/s10826-018-1209-y

McHale, J. P., Fivaz-Depeursinge, E. (1999). Understanding triadic and family group interactions during infancy and toddlerhood. Clinical Child and Family Psychology Review, 2(2), 107-127. https://doi. org/10.1023/A:1021847714749

McNeil, C. B., Eyberg, S., Hembree Eisenstadt, T., Newcomb, K., Funderburk, B. (1991). Parent-child interaction therapy with behavior problem children: Generalization of treatment effects to the school setting. Journal of Clinical Child and Adolescent Psychology, 20(2), 140-151. https:// doi.org/10.1207/s15374424jccp2002_5 
McNeil, C. B., Hembree-Kigin, T. L. (2010). Parent-child interaction therapy. Nowy Jork: Springer Science \& Business Media. https://doi. org/10.1007/978-0-387-88639-8

Mesman, J. (2010). Maternal responsiveness to infants: Comparing microand macro-level measures. Attachment \& Human Development, 12(1-2), 143-149. https://doi.org/10.1080/14616730903484763

Mesman, J., Minter, T., Angnged, A. (2016). Received sensitivity: Adapting Ainsworth's scale to capture sensitivity in a multiple-caregiver context. Attachment \& Human Development, 18(2), 101-114. https://doi.or $\mathrm{g} / 10.1080 / 14616734.2015 .1133681$

Mesman, J., van IJzendoorn, M. H., Bakermans-Kranenburg, M. J. (2009). The many faces of the Still-Face Paradigm: A review and meta-analysis. Developmental Review, 29(2), 120-162. https://doi.org/10.1016/j. dr.2009.02.001

Messinger, D., Fogel, A. (2007). The interactive development of social smiling. Advances in Child Development and Behaviour, 35, 328-366. https:// doi.org/10.1016/B978-0-12-009735-7.50014-1

Mick, E., Biederman, J., Faraone, S. V., Sayer, J., Kleinman, S. (2002). Case-control study of attention-deficit hyperactivity disorder and maternal smoking, alcohol use, and drug use during pregnancy. Journal of the American Academy of Child \& Adolescent Psychiatry, 41(4), 378-385. https://doi.org/10.1097/00004583-200204000-00009

Milewski, S. (2009). Wyrazy n-fonemowe i n-sylabowe w mowie dorosłych adresowanej do niemowląt. Psychologia Rozwojowa, 14(2), 43-56.

Milewski, S. (2011). Mowa dorostych kierowana do niemowlat. Studium fonostatystyczno-fonotaktyczne. Gdańsk: Harmonia Universalis.

Miranda, A., Tárraga, R., Fernández, M. I., Colomer, C., Pastor, G. (2015). Parenting stress in families of children with autism spectrum disorder and ADHD. Exceptional Children, 82(1), 81-95. https://doi. org/10.1177/0014402915585479

Miser, T. M., Hupp, J. M. (2012). The influence of socioeconomic status, home environment, and childcare on child language abilities. Current Psychology, 31(2), 144 -159. https://doi.org/10.1007/s12144-012-9139-0

Moffitt, T. E. (2005). The new look of behavioral genetics in developmental psychopathology: Gene-environment interplay in antisocial behaviors. Psychological Bulletin, 131(4), 533-554. https://doi.org/10.1037/00332909.131.4.533 
Montague, D. P., Walker-Andrews, A. S. (2001). Peekaboo: A new look at infants' perception of emotion expressions. Developmental Psychology, 37(6), 826-838. https://doi.org/10.1037/0012-1649.37.6.826

Moore, J. B., Saylor, C. F., Boyce, G. C. (1998). Parent-child interaction and developmental outcomes in medically fragile, high-risk children. Children's Health Care, 27(2), 97-112. https://doi.org/10.1207/ s15326888chc2702_2

Morimoto, C., Hida, E., Shima, K., Okamura, H. (2018). Temporal processing instability with millisecond accuracy is a cardinal feature of sensorimotor impairments in autism spectrum disorder: Analysis using the synchronized finger-tapping task. Journal of Autism and Developmental Disorders, 48(2), 351-360. https://doi.org/10.1007/s10803-017-3334-7

Morton, J., Johnson, M. H. (1991). CONSPEC and CONLERN: A two-process theory of infant face recognition. Psychological Review, 98(2), 164181. https://doi.org/10.1037/0033-295X.98.2.164

Mundy, P., Block, J., Delgado, C., Pomares, Y., Van Hecke, A. V., Parlade, M. V. (2007). Individual differences and the development of joint attention in infancy. Child Development, 78(3), 938-954. https://doi.org/10.1111/ j.1467-8624.2007.01042.x

Mundy, P., Kasari, C., Sigman, M., Ruskin, E. (1995). Nonverbal communication and early language acquisition in children with Down syndrome and in normally developing children. Journal of Speech, Language, and Hearing Research, 38(1), 157-167. https://doi.org/10.1044/jshr.3801.157

Mundy, P., Newell, L. (2007). Attention, joint attention, and social cognition. Current Directions in Psychological Science, 16(5), 269-274. https://doi. org/10.1111/j.1467-8721.2007.00518.x

Mundy, P., Sullivan, L., Mastergeorge, A. M. (2009). A parallel and distributed-processing model of joint attention, social cognition and autism. Autism Research, 2(1), 2-21. https://doi.org/10.1002/aur.61

Munson, L. J., Odom, S. L. (1996). Review of rating scales that measure parent-infant interaction. Topics in Early Childhood Special Education, 16(1), 1-25. https://doi.org/10.1177/027112149601600104

Murray, L., Fiori-Cowley, A., Cooper, P. (1996). The impact of postnatal depression and associated adversity on early mother-infant interactions and later infant outcome. Child Development, 67(5), 2512-2526. https:// doi.org/10.1111/j.1467-8624.1996.tb01871.x

Murray, L., Hentges, F., Hill, J., Karpf, J., Mistry, B., Kreutz, M., Cleft Lip and Palate Study Team (2008). The effect of cleft lip and palate, and the 
timing of lip repair on mother-infant interactions and infant development. Journal of Child Psychology and Psychiatry, 49(2), 115-123. https:// doi.org/10.1111/j.1469-7610.2007.01833.x

Namysłowska, I., Wolańczyk, T. (2010). Stanowisko konsultanta krajowego w dziedzinie psychiatrii dzieci i młodzieży oraz konsultanta wojewódzkiego (województwo mazowieckie) dotyczące kompleksowego (obejmującego psychoterapię) leczenia zespołu nadpobudliwości psychoruchowej (ADHD) i zaburzenia hiperkinetycznego. Psychiatria i Psychologia Kliniczna, 10(1), 59-60.

Neece, C. L. (2014). Mindfulness-based stress reduction for parents of young children with developmental delays: Implications for parental mental health and child behavior problems. Journal of Applied Research in Intellectual Disabilities, 27(2), 174-186. https://doi.org/10.1111/jar.12064

Nelson, M. M., Olsen, B. (2018). Dyadic Parent-Child Interaction Coding System (DPICS): An adaptable measure of parent and child behavior during dyadic interactions. W: L. N. Niec (red.), Handbook of parent-child interaction therapy (s. 285-302). Cham: Springer. https://doi. org/10.1007/978-3-319-97698-3

Nemeroff, C. B. (2016). Paradise lost: The neurobiological and clinical consequences of child abuse and neglect. Neuron, 89(5), 892-909. https:// doi.org/10.1016/j.neuron.2016.01.019

Nęcka, E., Orzechowski, J., Szymura, B. (2007). Psychologia poznawcza. Warszawa: Wydawnictwo Naukowe PWN.

Niedźwiecka, A., Ramotowska, S., Tomalski, P. (2017). Mutual gaze during early mother-infant interactions promotes attention control development. Child Development, 89(6), 2230-2244. https://doi.org/10.1111/ cdev. 12830

Nishitani, S., Miyamura, T., Tagawa, M., Sumi, M., Takase, R., Doi, H., Shinohara, K. (2009). The calming effect of a maternal breast milk odor on the human newborn infant. Neuroscience Research, 63(1), 66-71. https:// doi.org/10.1016/j.neures.2008.10.007

Nixon, R. D. (2001). Changes in hyperactivity and temperament in behaviourally disturbed preschoolers after parent-child interaction therapy (PCIT). Behaviour Change, 18(3), 168-176. https://doi.org/10.1375/ bech.18.3.168

Nomikou, I., Leonardi, G., Rohlfing, K. J., Rączaszek-Leonardi, J. (2016). Constructing interaction: The development of gaze dynamics. Infant and Child Development, 25(3), 277-295. https://doi.org/10.1002/icd.1975 
Northrup, J. B., Iverson, J. M. (2015). Vocal coordination during early parent-infant interactions predicts language outcome in infant siblings of children with autism spectrum disorder. Infancy, 20(5), 523-547. https:// doi.org/10.1111/infa.12090

Nyström, P., Ljunghammar, T., Rosander, K., von Hofsten, C. (2011). Using $\mathrm{mu}$ rhythm desynchronization to measure mirror neuron activity in infants. Developmental Science, 14(2), 327-335. https://doi.org/10.1111/ j.1467-7687.2010.00979.x

Obradović, J., Yousafzai, A. K., Finch, J. E., Rasheed, M. A. (2016). Maternal scaffolding and home stimulation: Key mediators of early intervention effects on children's cognitive development. Developmental Psychology, 52(9), 1409-1421. http://doi.org/10.1037/dev0000182

Olafsen, K. S., Rønning, J. A., Handegård, B. H., Ulvund, S. E., Dahl, L. B., Kaaresen, P. I. (2012). Regulatory competence and social communication in term and preterm infants at 12 months corrected age. Results from a randomized controlled trial. Infant Behavior and Development, 35(1), 140-149. https://doi.org/10.1016/j.infbeh.2011.08.001

Oller, D. K., Niyogi, P., Gray, S., Richards, J. A., Gilkerson, J., Xu, D., Warren, S. F. (2010). Automated vocal analysis of naturalistic recordings from children with autism, language delay, and typical development. Proceedings of the National Academy of Sciences, 107(30), 13354-13359. https:// doi.org/10.1073/pnas.1003882107

Olsson, M. B., Hwang, C. P. (2001). Depression in mothers and fathers of children with intellectual disability. Journal of Intellectual Disability Research, 45(6), 535-543. https://doi.org/10.1046/j.1365-2788.2001.00372.x

Orri, M., Tremblay, R. E., Japel, C., Boivin, M., Vitaro, F., Losier, T., ..., Côté, S. M. (2019). Early childhood child care and disruptive behavior problems during adolescence: A 17-year population-based propensity score study. Journal of Child Psychology and Psychiatry, 60(11), 1174-1182. https://doi.org/10.1111/jcpp.13065

Osório, A., Martins, C., Meins, E., Martins, E. C., Soares, I. (2011). Individual and relational contributions to parallel and joint attention in infancy. Infant Behavior and Development, 34(4), 515-524. https://doi.org/10.1016/j. infbeh.2011.07.005

Oster, H. (2003). Emotion in the infant's face. Annals of the New York Academy of Sciences, 1000(1), 197-204. https://doi.org/10.1196/annals.1280.024 
Papoušek, M. (2007). Communication in early infancy: An arena of intersubjective learning. Infant Behavior and Development, 30(2), 258-266. https://doi.org/10.1016/j.infbeh.2007.02.003

Papoušek, H., Papoušek, M. (2002). Intuitive parenting. W: M. H. Bornstein (red.), Handbook of parenting, t. 2: Biology and ecology of parenting (s. 183-203). Nowy Jork: Lawrence Erlbaum Associates, Publishers. https:// doi.org/10.4324/9780429401459

Parsons, C. E., Young, K. S., Murray, L., Stein, A., Kringelbach, M. L. (2010). The functional neuroanatomy of the evolving parent-infant relationship. Progress in Neurobiology, 91(3), 220-241. https://doi.org/10.1016/j. pneurobio.2010.03.001

Parr, J. R., Gray, L., Wigham, S., McConachie, H., Le Couteur, A. (2015). Measuring the relationship between the parental broader autism phenotype, parent-child interaction, and children's progress following parent mediated intervention. Research in Autism Spectrum Disorders, 20, 24-30. https://doi.org/10.1016/j.rasd.2015.07.006

Patterson, G. R., Dishion, T. J., Bank, L. (1984). Family interaction: A process model of deviancy training. Aggressive Behavior, 10(3), 253-267. https:// doi.org/10.1002/1098-2337(1984)10:3<253::AID-AB2480100309>3.0. $\mathrm{CO} ; 2-2$

Patterson, G. R., Reid, J. B. (1984). Social interactional processes within the family: The study of the moment-by-moment family transactions in which human social development is imbedded. Journal of Applied Developmental Psychology, 5(3), 237-262. https://doi.org/10.1016/01933973(84)90021-2

Pederson, D. R., Moran, G. (1995). A categorical description of infant-mother relationships in the home and its relation to Q-sort measures of infant-mother interaction. Monographs of the Society for Research in Child Development, 60, 111-132. https://doi.org/10.1111/j.1540-5834.1995. tb00207.x

Pederson, D. R., Moran, G., Sitko, C., Campbell, K., Ghesquire, K., Acton, H. (1990). Maternal sensitivity and the security of infant-mother attachment: A Q-sort study. Child Development, 61, 1974-1983. https://doi. org/10.1111/j.1467-8624.1990.tb03579.x

Pegg, J. E., Werker, J. F., McLeod, P. J. (1992). Preference for infant-directed over adult-directed speech: Evidence from 7-week-old infants. Infant Behavior and Development, 15(3), 325-345. https://doi.org/10.1016/01636383(92)80003-D 
Peltola, M. J., Leppänen, J. M., Hietanen, J. K. (2011). Enhanced cardiac and attentional responding to fearful faces in 7-month-old infants. Psychophysiology, 48(9), 1291-1298. https://doi.org/10.1111/j.14698986.2011.01188.x

Peltola, M. J., Leppänen, J. M., Mäki, S., Hietanen, J. K. (2009). Emergence of enhanced attention to fearful faces between 5 and 7 months of age. Social Cognitive and Affective Neuroscience, 4(2), 134-142. https://doi. org/10.1093/scan/nsn046

Pereira, A. F., Shen, H., Smith, L. B., Yu, C. (2009). A first-person perspective on a parent-child social interaction during object play. Proceedings of the Annual Meeting of the Cognitive Science Society, 31(31), 839-844.

Perra, O., Gattis, M. (2012). Attention engagement in early infancy. Infant Behavior and Development, 35(4), 635-644. https://doi.org/10.1016/j.infbeh.2012.06.004

Perry, R. E., Blair, C., Sullivan, R. M. (2017). Neurobiology of infant attachment: Attachment despite adversity and parental programming of emotionality. Current Opinion in Psychology, 17, 1-6. https://doi.org/10.1016/j. copsyc.2017.04.022

Phillips, D. A., Shonkoff, J. P. (red.). (2000). From neurons to neighborhoods: The science of early childhood development. Waszyngton: National Academy Press. https://doi.org/10.17226/9824

Pickles, A., Le Couteur, A., Leadbitter, K., Salomone, E., Cole-Fletcher, R., Tobin, H., Aldred, C. (2016). Parent-mediated social communication therapy for young children with autism (PACT): Long-term follow-up of a randomised controlled trial. The Lancet, 388(10059), 2501-2509. https://doi.org/10.1016/S0140-6736(16)31229-6

Piełuć, M., Fludra, M. (2010). Wideotrening Komunikacji jako metoda wspierająca rozwój emocjonalno-społeczny dziecka z trudnościami w komunikowaniu się werbalnym. Psychologia Rozwojowa, 15(1), 89-97.

Pierce, K., Gazestani, V. H., Bacon, E., Barnes, C. C., Cha, D., Nalabolu, S., Courchesne, E. (2019). Evaluation of the diagnostic stability of the early autism spectrum disorder phenotype in the general population starting at 12 months. JAMA Pediatrics, 173(6), 578-587. https://doi.org/10.1001/ jamapediatrics.2019.0624

Pineda, J. A. (2005). The functional significance of mu rhythms: Translating „seeing” and "hearing” into „doing”. Brain Research Reviews, 50(1), 57-68. https://doi.org/10.1016/j.brainresrev.2005.04.005 
Pisula, E. (2003). Autyzm i przywiązanie. Studia nad interakcjami dzieci autystycznych i ich matek. Sopot: Gdańskie Wydawnictwo Psychologiczne.

Pisula, E. (2008). Interactions of fathers and their children with autism. Polish Psychological Bulletin, 39(1), 35-41. https://doi.org/10.2478/v10059008-0005-8

Pisula, E., Porębowicz-Dörsmann, A. (2017). Family functioning, parenting stress and quality of life in mothers and fathers of Polish children with high functioning autism or Asperger syndrome. PLoS ONE, 12(10), e0186536. https://doi.org/10.1371/journal.pone.0186536

Pisula, E., Ziegart-Sadowska, K. (2015). Broader autism phenotype in siblings of children with ASD - A review. International Journal of Molecular Sciences, 16(6), 13217-13258. https://doi.org/10.3390/ijms160613217

Piven, J., Palmer, P., Jacobi, D., Childress, D., Arndt, S. (1997). Broader autism phenotype: Evidence from a family history study of multiple-incidence autism families. American Journal of Psychiatry, 154(2), 185-190. https://doi.org/10.1176/ajp.154.2.185

Poehlmann, J., Fiese, B. H. (2001). Parent-infant interaction as a mediator of the relation between neonatal risk status and 12-month cognitive development. Infant Behavior and Development, 24(2), 171-188. https://doi. org/10.1016/S0163-6383(01)00073-X

Polikovsky, S., Kameda, Y., Ohta, Y. (2013). Facial micro-expression detection in hi-speed video based on facial action coding system (FACS). IEICE Transactions on Information and Systems, 96(1), 81-92. https://doi. org/10.1587/transinf.E96.D.81

Posada, G., Kaloustian, G., Richmond, M. K., Moreno, A. J. (2007). Maternal secure base support and preschoolers' secure base behavior in natural environments. Attachment \& Human Development, 9(4), 393-411. https://doi.org/10.1080/14616730701712316

Posner, M. I., Rothbart, M. K., Voelker, P. (2016). Developing brain networks of attention. Current Opinion in Pediatrics, 28(6), 720-724. https://doi. org/10.1097/MOP.0000000000000413

Pungello, E. P., Iruka, I. U., Dotterer, A. M., Mills-Koonce, R., Reznick, J. S. (2009). The effects of socioeconomic status, race, and parenting on language development in early childhood. Developmental Psychology, 45(2), 544-557. https://doi.org/10.1037/a0013917

Querleu, D., Lefebvre, C., Titran, M., Renard, X., Morillion, M., Crepin, G. (1984). Reaction of the newborn infant less than 2 hours after birth to 
the maternal voice. Journal de Gynécologie, Obstetrique et Biologie de la Reproduction, 13(2), 125-134.

Rayson, H., Bonaiuto, J. J., Ferrari, P. F., Murray, L. (2017). Early maternal mirroring predicts infant motor system activation during facial expression observation. Scientific Reports, 7(1), 1-11. https://doi.org/10.1038/ s41598-017-12097-w

Rączaszek-Leonardi, J., Nomikou, I., Rohlfing, K. J. (2013). Young children's dialogical actions: The beginnings of purposeful intersubjectivity. IEEE Transactions on Autonomous Mental Development, 5(3), 210-221. https:// doi.org/10.1109/TAMD.2013.2273258

Reddy, V. (2003). On being the object of attention: Implications for self-other consciousness. Trends in Cognitive Sciences, 7(9), 397-402. https://doi. org/10.1016/S1364-6613(03)00191-8

Reindl, V., Gerloff, C., Scharke, W., Konrad, K. (2018). Brain-to-brain synchrony in parent-child dyads and the relationship with emotion regulation revealed by fNIRS-based hyperscanning. NeuroImage, 178, 493-502. https://doi.org/10.1016/j.neuroimage.2018.05.060

Reynolds, G. D., Romano, A. C. (2016). The development of attention systems and working memory in infancy. Frontiers in Systems Neuroscience, 10, 15. https://doi.org/10.3389/fnsys.2016.00015

Robins, D. L., Casagrande, K., Barton, M., Chen, C. M. A., Dumont-Mathieu, T., Fein, D. (2014). Validation of the modified checklist for autism in toddlers, revised with follow-up (M-CHAT-R/F). Pediatrics, 133(1), 37-45.

Robson, K. S. (1967). The role of eye-to-eye contact in maternal-infant attachment. Journal of Child Psychology and Psychiatry, 8(1), 13-25. https:// doi.org/10.1111/j.1469-7610.1967.tb02176.x

Rochat, N. A. C. F., de Campos, A. C., Silva, F. P. D. S., Tudella, E. (2013). Adaptive actions of young infants in the task of reaching for objects. Developmental Psychobiology, 55(3), 275-282. https://doi.org/10.1002/ dev.21026

Rochat, P. (1992). Self-sitting and reaching in 5- to 8-month-old infants: The impact of posture and its development on early eye-hand coordination. Journal of Motor Behavior, 24(2), 210-220. https://doi.org/10.1080/0022 2895.1992.9941616

Rodrigue, J. R., Morgan, S. B., Geffken, G. (1990). Families of autistic children: Psychological functioning of mothers. Journal of Clinical Child Psychology, 19(4), 371-379. https://doi.org/10.1207/s15374424jccp1904_9 
Rohlfing, K. J., Nomikou, I. (2014). Intermodal synchrony as a form of maternal responsiveness: Association with language development. Language, Interaction and Acquisition, 5(1), 117-136. https://doi.org/10.1075/ lia.5.1.06roh

Ros, R., Hernandez, J., Graziano, P. A., Bagner, D. M. (2016). Parent training for children with or at risk for developmental delay: The role of parental homework completion. Behavior Therapy, 47(1), 1-13. https://doi. org/10.1016/j.beth.2015.08.004

Rosenblum, K. L., Dayton, C. J., Muzik, M. (2009). Infant social and emotional development. Emerging competence in a relational context. W: C. H. Zeanah, Jr. (red.), Handbook of infant mental health (s. 80-103). Nowy Jork: The Guilford Press.

Rothbart, M. K., Sheese, B. E., Rueda, M. R., Posner, M. I. (2011). Developing mechanisms of self-regulation in early life. Emotion Review, 3(2), 207-213. https://doi.org/10.1177/1754073910387943

Ruble, L., McDuffie, A., King, A. S., Lorenz, D. (2008). Caregiver responsiveness and social interaction behaviors of young children with autism. Topics in Early Childhood Special Education, 28(3), 158-170. https:// doi.org/10.1177/0271121408323009

Ryan, R. M., Martin, A., Brooks-Gunn, J. (2006). Is one good parent good enough? Patterns of mother and father parenting and child cognitive outcomes at 24 and 36 months. Parenting, 6(2-3), 211-228. https://doi. org/10.1080/15295192.2006.9681306

Rybakowski, F., Białek, A., Chojnicka, I., Dziechciarz, P., Horvath, A., Janas-Kozik, M., Sykut-Cegielska, J. (2014). Zaburzenia ze spektrum autyzmu - epidemiologia, objawy, współzachorowalność i rozpoznawanie. Psychiatria Polska, 48(4).

Sameroff, A. J., Fiese, B. H. (2000). Models of development and developmental risk. W: C. H. Zeanah, Jr. (red.), Handbook of infant mental health (s. 3-19). Nowy Jork: The Guilford Press.

Sameroff, A. J., Mackenzie, M. J. (2003). A quarter-century of the transactional model: How have things changed? Zero to Three, 24(1), 14-22.

Schachner, A., Hannon, E. E. (2011). Infant-directed speech drives social preferences in 5-month-old infants. Developmental Psychology, 47(1), 19-25. https://doi.org/10.1037/a0020740

Schaffer, H. R. (1996/2006). Rozwój społeczny: dzieciństwo i młodość. Kraków: Wydawnictwo Uniwersytetu Jagiellońskiego. 
Schaffer, D. R., Kipp, K. (2015). Psychologia rozwoju. Od dziecka do dorosłości. Gdańsk: Harmonia Universalis.

Schilbach, L. (2015). Eye to eye, face to face and brain to brain: Novel approaches to study the behavioral dynamics and neural mechanisms of social interactions. Current Opinion in Behavioral Sciences, 3, 130-135. https://doi.org/10.1016/j.cobeha.2015.03.006

Schwartz, J. I. (2004). An observational study of mother/child and father/ child interactions in story reading. Journal of Research in Childhood Education, 19(2), 105-114. https://doi.org/10.1080/02568540409595058

Schwichtenberg, A. J., Kellerman, A. M., Young, G. S., Miller, M., Ozonoff, S. (2018). Mothers of children with autism spectrum disorders: Play behaviors with infant siblings and social responsiveness. Autism, 23(4), 821-833. https://doi.org/10.1177/1362361318782220

Senator, D. (2006). Wzorce więzi w triadzie matka - ojciec - 3-miesięczne niemowle (Niepublikowana praca doktorska). Uniwersytet Warszawski. Warszawa.

Senju, A., Johnson, M. H. (2009a). Atypical eye contact in autism: Models, mechanisms and development. Neuroscience \& Biobehavioral Reviews, 33(8), 1204-1214. https://doi.org/10.1016/j.neubiorev.2009.06.001

Senju, A., Johnson, M. H. (2009b). The eye contact effect: Mechanisms and development. Trends in Cognitive Science, 13, 127-134. https://doi. org/10.1016/j.tics.2008.11.009

Serrano, J. M., Iglesias, J., Loeches, A. (1992). Visual discrimination and recognition of facial expressions of anger, fear, and surprise in 4- to 6month-old infants. Developmental Psychobiology, 25(6), 411-425. https:// doi.org/10.1002/dev.420250603

Sethna, V., Perry, E., Domoney, J., Iles, J., Psychogiou, L., Rowbotham, N. E., Ramchandani, P. G. (2017). Father-child interactions at 3 months and 24 months: Contributions to children's cognitive development at 24 months. Infant Mental Health Journal, 38(3), 378-390. https://doi. org/10.1002/imhj.21642

Sheinkopf, S. J., Tenenbaum, E. J., Messinger, D. S., Miller-Loncar, C. L., Tronick, E., Lagasse, L. L., Hammond, J. (2017). Maternal and infant affect at 4 months predicts performance and verbal IQ at 4 and 7 years in a diverse population. Developmental Science, 20(5), e12479. https:// doi.org/10.1111/desc.12479

Shephard, E., Milosavljevic, B., Pasco, G., Jones, E. J., Gliga, T., Happé, F., BASIS Team. (2017). Mid-childhood outcomes of infant siblings at 
familial high-risk of autism spectrum disorder. Autism Research, 10(3), 546-557. https://doi.org/10.1002/aur.1733

Shire, S. Y., Gulsrud, A., Kasari, C. (2016). Increasing responsive parentchild interactions and joint engagement: Comparing the influence of parent-mediated intervention and parent psychoeducation. Journal of Autism and Developmental Disorders, 46(5), 1737-1747. https://doi. org/10.1007/s10803-016-2702-z

Siegel, D. J. (1999). The developing mind. Nowy Jork: Guilford Press.

Sigman, M., Ruskin, E., Arbelle, S., Corona, R., Dissanayake, C., Espinosa, M., Robinson, B. F. (1999). Continuity and change in the social competence of children with autism, Down syndrome, and developmental delays. Monographs of the Society for Research in Child Development, 64(1), i-139. https://doi.org/10.1111/1540-5834.00002

Singh, L., Morgan, J. L., Best, C. T. (2002). Infants' listening preferences: Baby talk or happy talk? Infancy, 3(3), 365-394. https://doi.org/10.1207/ S15327078IN0303_5

Smith, L. B., Thelen, E. (2003). Development as a dynamic system. Trends in Cognitive Sciences, 7(8), 343-348. https://doi.org/10.1016/S13646613(03)00156-6

Smith, P. K., Vollstedt, R. (1985). On defining play: An empirical study of the relationship between play and various play criteria. Child Development, 56(4), 1042-1050. https://doi.org/10.2307/1130114

Sokol, S. (1978). Measurement of infant visual acuity from pattern reversal evoked potentials. Vision Research, 18(1), 33-39. https://doi. org/10.1016/0042-6989(78)90074-3

Solomon, M., Ono, M., Timmer, S., Goodlin-Jones, B. (2008). The effectiveness of parent-child interaction therapy for families of children on the autism spectrum. Journal of Autism and Developmental Disorders, 38(9), 1767-1776. https://doi.org/10.1007/s10803-008-0567-5

Sonuga-Barke, E. J., Daley, D., Thompson, M. (2002). Does maternal ADHD reduce the effectiveness of parent training for preschool children's ADHD? Journal of the American Academy of Child \& Adolescent Psychiatry, 41(6), 696-702. https://doi.org/10.1097/00004583-200206000-00009

Sorce, J. F., Emde, R. N., Campos, J. J., Klinnert, M. D. (1985). Maternal emotional signaling: Its effect on the visual cliff behavior of 1-year-olds. Developmental Psychology, 21(1), 195-200. https://doi.org/10.1037/00121649.21.1.195 
Sorce, J. F., Emde, R. N., Frank, M. (1982). Maternal referencing in normal and Down's syndrome infants. W: R. N. Emde, R. J. Harmon (red.), The development of attachment and affiliative systems (s. 281-292). Boston: Springer. https://doi.org/10.1007/978-1-4684-4076-8

Sorkhabi, N. (2012). Parent socialization effects in different cultures: Significance of directive parenting. Psychological Reports, 110(3), 854-878. https://doi.org/10.2466/10.02.17.21.PR0.110.3.854-878

Spielberger, C. D., Strelau, J., Tysarczyk, M., Wrześniewski, K. (1987). Inwentarz Stanu i Cechy Lęku STAI (ISCL). Warszawa: Pracownia Testów Psychologicznych PTP.

Stack, D. M. (2008). The salience of touch and physical contact during infancy: Unraveling some of the mysteries of the somesthetic sense. W: G. Bremner, A. Fogel (red.), Blackwell handbook of infant development (s. 351-378). Padstow: Blackwell Publishers Ltd. https://doi. org/10.1002/9780470996348

Stack, D. M., Muir, D. W. (1990). Tactile stimulation as a component of social interchange: New interpretations for the still-face effect. British Journal of Developmental Psychology, 8(2), 131-145. https://doi.org/10.1111/j.2044835X.1990.tb00828.x

Steelman, L. M., Assel, M. A., Swank, P. R., Smith, K. E., Landry, S. H. (2002). Early maternal warm responsiveness as a predictor of child social skills: Direct and indirect paths of influence over time. Journal of Applied Developmental Psychology, 23(2), 135-156. https://doi.org/10.1016/S01933973(02)00101-6

Steiner, A. M., Gengoux, G. W., Smith, A., Chawarska, K. (2018). Parentchild interaction synchrony for infants at-risk for autism spectrum disorder. Journal of Autism and Developmental Disorders, 48(10), 3562 3572. https://doi.org/10.1007/s10803-018-3624-8

Stemplewska-Żakowicz, K. (2009). Diagnoza psychologiczna. Gdańsk: Gdańskie Wydawnictwo Psychologiczne.

Stemplewska-Żakowicz, K., Paluchowski, W. J. (2011). Podstawy diagnozy psychologicznej. W: J. Strelau, D. Doliński (red.), Psychologia akademicka. Podręcznik, t. 2. (s. 23-94). Gdańsk: Gdańskie Wydawnictwo Psychologiczne.

Stern, D. (1985). The interpersonal world of the infant. A view from psychoanalysis and developmental psychology. Nowy Jork: Basic Books. https:// doi.org/10.4324/9780429482137 
Stern, D. (1998). The motherhood constellation. Nowy Jork: Routledge. https://doi.org/10.4324/9780429482489

Stevenson, R. A., Segers, M., Ferber, S., Barense, M. D., Camarata, S., Wallace, M. T. (2016). Keeping time in the brain: Autism spectrum disorder and audiovisual temporal processing. Autism Research, 9(7), 720-738. https://doi.org/10.1002/aur.1566

Stöckli, S., Schulte-Mecklenbeck, M., Borer, S., Samson, A. C. (2018). Facial expression analysis with AFFDEX and FACET: A validation study. Behavior Research Methods, 50(4), 1446-1460. https://doi.org/10.3758/ s13428-017-0996-1

Strathearn, L. (2011). Maternal neglect: Oxytocin, dopamine and the neurobiology of attachment. Journal of Neuroendocrinology, 23(11), 1054-1065. https://doi.org/10.1111/j.1365-2826.2011.02228.x

Sullivan, R., Perry, R., Sloan, A., Kleinhaus, K., Burtchen, N. (2011). Infant bonding and attachment to the caregiver: Insights from basic and clinical science. Clinics in Perinatology, 38(4), 643-655. https://doi. org/10.1016/j.clp.2011.08.011

Super, C. M. (1976). Environmental effects on motor development: The case of „African infant precocity”. Developmental Medicine and Child Neurology, 18(5), 561-567. https://doi.org/10.1111/j.1469-8749.1976.tb04202.x

Super, C. M., Harkness, S. (1986). The developmental niche: A conceptualization at the interface of child and culture. International Journal of Behavioral Development, 9(4), 545-569. https://doi. org/10.1177/016502548600900409

Swain, J. E., Ho, S. H. S. (2017). Neuroendocrine mechanisms for parental sensitivity: Overview, recent advances and future directions. Current Opinion in Psychology, 15, 105-110. https://doi.org/10.1016/j.copsyc.2017.02.027

Swain, J. E., Lorberbaum, J. P., Kose, S., Strathearn, L. (2007). Brain basis of early parent-infant interactions: Psychology, physiology, and in vivo functional neuroimaging studies. Journal of Child Psychology and Psychiatry, 48(3-4), 262-287. https://doi.org/10.1111/j.1469-7610.2007.01731.x

Swanson, M. R., Shen, M. D., Wolff, J. J., Boyd, B., Clements, M., Rehg, J., Hazlett, H. C. (2018). Naturalistic language recordings reveal „hypervocal" infants at high familial risk for autism. Child Development, 89(2), 60-73. https://doi.org/10.1111/cdev.12777 
Szeląg, E., Kowalska, J., Gałkowski, T., Pöppel, E. (2004). Temporal processing deficits in high-functioning children with autism. British Journal of Psychology, 95(3), 269-282. https://doi.org/10.1348/0007126041528167

Talbott, M. R., Nelson, C. A., Tager-Flusberg, H. (2015). Maternal gesture use and language development in infant siblings of children with autism spectrum disorder. Journal of Autism and Developmental Disorders, 45(1), 4-14. https://doi.org/10.1007/s10803-013-1820-0

Talbott, M. R., Nelson, C. A., Tager-Flusberg, H. (2016). Maternal vocal feedback to 9-month-old infant siblings of children with ASD. Autism Research, 9(4), 460-470. https://doi.org/10.1002/aur.1521

Tamis-LeMonda, C. S., Kuchirko, Y., Tafuro, L. (2013). From action to interaction: Infant object exploration and mothers' contingent responsiveness. IEEE Transactions on Autonomous Mental Development, 5(3), 202-209. https://doi.org/10.1109/TAMD.2013.2269905

Tamis-LeMonda, C. S., Shannon, J. D., Cabrera, N. J., Lamb, M. E. (2004). Fathers and mothers at play with their 2- and 3-year-olds: Contributions to language and cognitive development. Child Development, 75(6), 1806-1820. https://doi.org/10.1111/j.1467-8624.2004.00818.x

Teicher, M. H., Samson, J. A. (2016). Annual research review: Enduring neurobiological effects of childhood abuse and neglect. Journal of Child Psychology and Psychiatry, 57(3), 241-266. https://doi.org/10.1111/jcpp.12507

Tenenbaum, E. J., Shah, R. J., Sobel, D. M., Malle, B. F., Morgan, J. L. (2013). Increased focus on the mouth among infants in the first year of life: A longitudinal eye-tracking study. Infancy, 18(4), 534-553. https://doi. org/10.1111/j.1532-7078.2012.00135.x

Theule, J., Wiener, J., Rogers, M. A., Marton, I. (2011). Predicting parenting stress in families of children with ADHD: Parent and contextual factors. Journal of Child and Family Studies, 20(5), 640-647. https://doi. org/10.1007/s10826-010-9439-7

Theule, J., Wiener, J., Tannock, R., Jenkins, J. M. (2013). Parenting stress in families of children with ADHD: A meta-analysis. Journal of Emotional and Behavioral Disorders, 21(1), 3-17. https://doi. org/10.1177/1063426610387433

Thomas, E. A., Martin, J. A. (1976). Analyses of parent-infant interaction. Psychological Review, 83(2), 141-156. https://doi.org/10.1037/0033295X.83.2.141

Tomasello, M. (1995). Joint attention as social cognition. W: C. Moore, P. Dunham, (red.), Joint attention: Its origins and role in 
development (s. 103-113). Nowy Jork: Psychology Press. https://doi. org/10.4324/9781315806617

Tomaszewski, P., Rosik, P. (2002). Czy polski język migowy jest prawdziwym językiem. W: G. Jastrzębowska, Z. Tarkowski (red.), Człowiek wobec ograniczeń. Niepelnosprawność. Komunikacja. Terapia. (s. 133-165). Lublin: Wyd. Fundacji ORATOR.

Trainor, L. J., Austin, C. M., Desjardins, R. N. (2000). Is infant-directed speech prosody a result of the vocal expression of emotion? Psychological Science, 11(3), 188-195. https://doi.org/10.1111/1467-9280.00240

Trempała, J. (red.). (2012). Psychologia rozwoju człowieka. Warszawa: Wydawnictwo Naukowe PWN.

Trevarthen, C., Aitken, K. J. (2001). Infant intersubjectivity: Research, theory, and clinical applications. Journal of Child Psychology and Psychiatry, 42(1), 3-48. https://doi.org/10.1111/1469-7610.00701

Trevarthen, C., Daniel, S. (2005). Disorganized rhythm and synchrony: Early signs of autism and Rett syndrome. Brain and Development, 27, 25-34. https://doi.org/10.1016/j.braindev.2005.03.016

Treyvaud, K., Doyle, L. W., Lee, K. J., Ure, A., Inder, T. E., Hunt, R. W., Anderson, P. J. (2016). Parenting behavior at 2 years predicts school-age performance at 7 years in very preterm children. Journal of Child Psychology and Psychiatry, 57(7), 814-821. https://doi.org/10.1111/jcpp.12489

Tronick, E. Z. (1989). Emotions and emotional communication in infants. American Psychologist, 44, 112-119. https://doi.org/10.1037/0003066X.44.2.112

Tronick, E. Z., Cohn, J. E. (1987). Revised monadic phases manual. Niepublikowany manuskrypt.

Tronick, E. Z., Gianino, A. (1986). Interactive mismatch and repair: Challenges to the coping infant. Zero to Three, 6(3), 1-6.

Tsang, T., Atagi, N., Johnson, S. P. (2018). Selective attention to the mouth is associated with expressive language skills in monolingual and bilingual infants. Journal of Experimental Child Psychology, 169, 93-109. https:// doi.org/10.1016/j.jecp.2018.01.002

Tylenda, B., Barrett, R. P., Sachs III, H. T. (2014). Intellectual disability. W: M. Lewis, K. D. Rudolph (red.), Handbook of developmental psychopatholo$g y$ (s. 665-682). Nowy Jork: Springer Science \& Business Media. https:// doi.org/10.1007/978-1-4614-9608-3

Valstar, M., Pantic, M. (2006, czerwiec). Fully automatic facial action unit detection and temporal analysis. Proceedings of the Conference on 
Computer Vision and Pattern Recognition Workshop, 149. Pobrano z: https://ieeexplore.iee.org/abstract/document/1640595

Varendi, H., Porter, R. H., Winberg, J. (1994). Does the newborn baby find the nipple by smell? The Lancet, 344(8928), 989-990. https://doi. org/10.1016/S0140-6736(94)91645-4

Venuprasad, P., Dobhal, T., Paul, A., Nguyen, T. N., Gilman, A., Cosman, P., Chukoskie, L. (2019). Characterizing joint attention behavior during real world interactions using automated object and gaze detection. Proceedings of the 11th ACM Symposium on Eye Tracking Research \& Applications. Pobrano z: http://code.ucsd.edu/pcosman/ETRA_paper.pdf

Venuti, P., de Falco, S., Esposito, G., Bornstein, M. H. (2009). Mother-child play: children with Down syndrome and typical development. American Journal on Intellectual and Developmental Disabilities, 114(4), 274-288. https://doi.org/10.1352/1944-7558-114.4:274-288

Vetter, J. A. (2018). Parent-Child Interaction Therapy for autism spectrum and attention-deficit/hyperactivity disorders: A review of the literature. Child \& Family Behavior Therapy, 40(3), 204-232. https://doi.org/ 10.1080/07317107.2018.1487740

Vik, K., Rohde, R. (2014). Tiny moments of great importance: The Marte Meo method applied in the context of early mother-infant interaction and postnatal depression. Utilizing Daniel Stern's theory of 'schemas of being with' in understanding empirical findings and developing a stringent Marte Meo methodology. Clinical Child Psychology and Psychiatry, 19(1), 77-89. https://doi.org/10.1177/1359104512468286

Wagner, S. M., McNeil, C. B. (2008). Parent-child interaction therapy for ADHD: A conceptual overview and critical literature review. Child \& Family Behavior Therapy, 30(3), 231-256. https://doi. org/10.1080/07317100802275546

Wakschlag, L. S., Hans, S. L. (2002). Maternal smoking during pregnancy and conduct problems in high-risk youth: A developmental framework. Development and Psychopathology, 14(2), 351-369. https://doi. org/10.1017/S0954579402002092

Walle, E. A., Campos, J. J. (2014). Infant language development is related to the acquisition of walking. Developmental Psychology, 50(2), 336-348. https://doi.org/10.1037/a0033238

Wan, M. W., Green, J., Elsabbagh, M., Johnson, M., Charman, T., Plummer, F., BASIS Team. (2012). Parent-infant interaction in infant siblings at 
risk of autism. Research in Developmental Disabilities, 33(3), 924-932. https://doi.org/10.1016/j.ridd.2011.12.011

Wan, M. W., Green, J., Elsabbagh, M., Johnson, M., Charman, T., Plummer, F., BASIS Team. (2013). Quality of interaction between at-risk infants and caregiver at $12-15$ months is associated with 3-year autism outcome. Journal of Child Psychology and Psychiatry, 54, 763-771. https:// doi.org/10.1111/jcpp.12032

Wan, M. W., Brooks, A., Green, J., Abel, K., Elmadih, A. (2017). Psychometrics and validation of a brief rating measure of parent-infant interaction: Manchester assessment of caregiver-infant interaction. International Journal of Behavioral Development, 41(4), 542-549. https://doi. org/10.1177/0165025416631835

Wan, M. W., Green, J., Scott, J. (2019). A systematic review of parent-infant interaction in infants at risk of autism. Autism, 23(4), 811-820. https:// doi.org/10.1177/1362361318777484

Warlaumont, A. S., Oller, D. K., Dale, R., Richards, J. A., Gilkerson, J., Xu, D. (2010). Vocal interaction dynamics of children with and without autism. Proceedings of the Annual Meeting of the Cognitive Science Society, $32,121-126$.

Watson, L. R., Crais, E. R., Baranek, G. T., Turner-Brown, L., Sideris, J., Wakeford, L., Nowell, S. W. (2017). Parent-mediated intervention for one-year-olds screened as at-risk for autism spectrum disorder: A randomized controlled trial. Journal of Autism and Developmental Disorders, 47(11), 3520-3540. https://doi.org/10.1007/s10803-017-3268-0

Weiss, M., Hechtman, L., Weiss, G. (2000). ADHD in parents. Journal of the American Academy of Child \& Adolescent Psychiatry, 39(8), 1059-1061. https://doi.org/10.1097/00004583-200008000-00023

Winsler, A. (2009). Still talking to ourselves after all these years: A review of current research on private speech. W: A. Winsler, C. Fernyhough, I. Montero (red.), Private speech, executive functioning, and the development of verbal self-regulation (s. 3-41). Nowy Jork: Cambridge University Press. https://doi.org/10.1017/CBO9780511581533

Woltering, S., Lishak, V., Elliott, B., Ferraro, L., Granic, I. (2015). Dyadic attunement and physiological synchrony during mother-child interactions: An exploratory study in children with and without externalizing behavior problems. Journal of Psychopathology and Behavioral Assessment, 37(4), 624-633. https://doi.org/10.1007/s10862-015-9480-3 
Wood, D., Bruner, J. S., Ross, G. (1976). The role of tutoring in problem solving. Journal of Child Psychology and Psychiatry, 17(2), 89-100. https:// doi.org/10.1111/j.1469-7610.1976.tb00381.x

World Health Organization. (2003). Kangaroo mother care: A practical guide. Genewa: World Health Organization.

World Health Organization. (2018). Międzynarodowa Statystyczna Klasyfikacja Chorób i Problemów Zdrowotnych ICD-11. Genewa: World Health Organization.

Wygotski, L. S. (1934/1989). Myślenie i mowa. Warszawa: Państwowe Wydawnictwo Naukowe.

Wygotski, L. S. (2002). Wybrane prace psychologiczne II: Dzieciństwo i dorastanie. Poznań: Wydawnictwo Zysk i S-ka.

Yale, M. E., Messinger, D. S., Cobo-Lewis, A. B., Delgado, C. F. (2003). The temporal coordination of early infant communication. Developmental Psychology, 39(5), 815-824. https://doi.org/10.1037/0012-1649.39.5.815

Yirmiya, N., Gamliel, I., Pilowsky, T., Feldman, R., Baron-Cohen, S., Sigman, M. (2006). The development of siblings of children with autism at 4 and 14 months: Social engagement, communication, and cognition. Journal of Child Psychology and Psychiatry, 47(5), 511-523. https://doi.org/10.1111/ j.1469-7610.2005.01528.x

Yoo, H., Bowman, D. A., Oller, D. K. (2018). The origin of protoconversation: An examination of caregiver responses to cry and speech-like vocalizations. Frontiers in Psychology, 9, 1510. https://doi.org/10.3389/ fpsyg.2018.01510

Yu, C., Smith, L. B. (2016a). Multiple sensory-motor pathways lead to coordinated visual attention. Cognitive Science, 41, 1-27. https://doi.org/10.1111/ cogs. 12366

Yu, C., Smith, L. B. (2016b). The social origins of sustained attention in oneyear-old human infants. Current Biology, 26, 1235-1240. https://doi. org/10.1016/j.cub.2016.03.026

Yu, C., Smith, L. B., Pereira, A. F. (2008). Grounding word learning in multimodal sensorimotor interaction. Proceedings of the Annual Meeting of the Cognitive Science Society, 30(30), 1017-1022.

Zalewska, M. (1998). Dziecko $w$ autoportrecie z zamalowana twarza. Warszawa: Jacek Santorski \& Co.

Zalewska, M. (2004). Charakterystyka podejścia interpersonalnego. W: J. Przesmycka (red.), Diagnoza psychologiczna dzieci z trudnościami w porozumiewaniu sie werbalnym. Materiały $z$ konferencji zorganizowanej 
przez Pracownię Terapii Neuropsychologicznej Instytutu Psychologii Uniwersytetu Wrocławskiego, Czerniawa, 16-19 października 2003 roku (s. 45-55). Wrocław: Wydawnictwo Uniwersytetu Wrocławskiego.

ZERO TO THREE. (2016). DC:0-5 $5^{\mathrm{TM}}$ Diagnostic classification of mental health and developmental disorders of infancy and early childhood. Waszyngton: ZERO TO THREE.

Zisser, A., Eyberg, S. M. (2010). Parent-child interaction therapy and the treatment of disruptive behavior disorders. W: J. R. Weisz, A. E. Kazdin (red.), Evidence-based psychotherapies for children and adolescents (s. 179-193). The Guilford Press.

Zwaigenbaum, L., Bauman, M. L., Stone, W. L., Yirmiya, N., Estes, A., Hansen, R. L., Kasari, C. (2015). Early identification of autism spectrum disorder: Recommendations for practice and research. Pediatrics, 136(Supplement 1), S10-S40. https://doi.org/10.1542/peds.2014-3667C 


\section{ZAtĄCZNIK A: \\ KARTA OCENY INTERAKCJI \\ DZIECKO-RODZIC}

\section{KARTA OCENY INTERAKCJI DZIECKO-RODZIC}

\section{DATA:}

WIEK DZIECKA:

MIEJSCE OBSERWACJI:

CZAS TRWANIA OBSERWACJI:

NUMER OBSERWACJI:
OSOBY OBECNE:

PODSTAWOWY/I OPIEKUN/OWIE:

SKŁAD OSOBOWY RODZINY:

OSOBY DOROSŁE:

DZIECI (WIEK): 


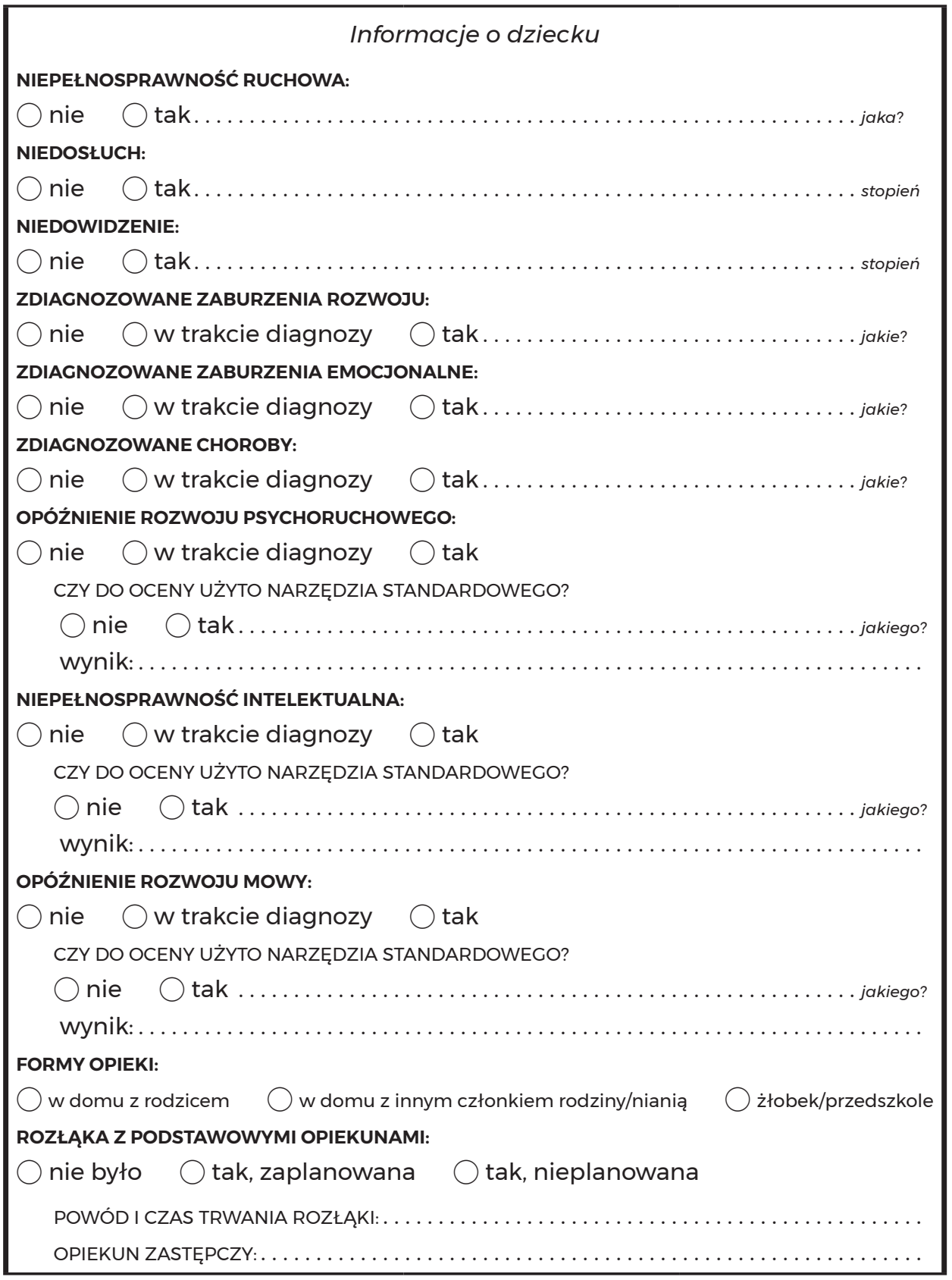




\begin{tabular}{|l|l|l|}
\hline \multicolumn{1}{|c|}{ Zachowania interakcyjne } & \multicolumn{1}{|c|}{ Opis } & $\begin{array}{c}\text { Zmiany w trakcie } \\
\text { obserwacji }\end{array}$ \\
\hline \multicolumn{2}{|c|}{ DZIECKO } & \\
\hline UWACA WZROKOWA & & \\
\hline Patrzenie na opiekuna & & \\
\hline $\begin{array}{l}\text { Nawiązywanie kontaktu } \\
\text { Wzrokowego z opiekunem }\end{array}$ & & \\
\hline $\begin{array}{l}\text { Unikanie kontaktu wzrokowego } \\
\text { zopiekunem }\end{array}$ & & \\
\hline Patrzenie na obcego & & \\
\hline $\begin{array}{l}\text { Nawiązywanie kontaktu } \\
\text { Wzrokowego z obcym }\end{array}$ & & \\
\hline $\begin{array}{l}\text { Unikanie kontaktu wzrokowego } \\
\text { z obcym }\end{array}$ & & \\
\hline Patrzenie na przedmioty & & \\
\hline $\begin{array}{l}\text { Przenoszenie wzroku, } \\
\text { utrzymywanie uwagi }\end{array}$ & & \\
\hline EMOcJE & & \\
\hline Radość & & \\
\hline Zaciekawienie & & \\
\hline Smutek & & \\
\hline Złość, rozdrażnienie & & \\
\hline Lęk, niepokój, napięcie & & \\
\hline Kierowanie emocji do opiekuna & & \\
\hline Kierowanie emocji do obcego & & \\
\hline PROKSEMIKA & & \\
\hline Pozostaje blisko opiekuna & & \\
\hline Pozostaje blisko innej osoby & & \\
\hline Pozostaje oddalone od osób & & \\
\hline AkTrwNość & & \\
\hline Szybkość, energia, ruchliwość & & \\
\hline Eksploracja & & \\
\hline
\end{tabular}




\begin{tabular}{|c|c|c|}
\hline Zabawa & & \\
\hline $\begin{array}{l}\text { Aktywność fizyczna, zabawy } \\
\text { ruchowe }\end{array}$ & & \\
\hline Trudno określić cel aktywności & & \\
\hline Zachowania stereotypowe & & \\
\hline $\begin{array}{l}\text { Zachowania destrukcyjne (np. } \\
\text { celowe niszczenie zabawek) }\end{array}$ & & \\
\hline Tematyka zabawy lub rozmów & & \\
\hline $\begin{array}{l}\text { Kierowanie aktywnością } \\
\text { opiekuna }\end{array}$ & & \\
\hline Kierowanie aktywnością obcego & & \\
\hline $\begin{array}{l}\text { Włączanie opiekuna w swoją } \\
\text { aktywność }\end{array}$ & & \\
\hline $\begin{array}{l}\text { Włączanie obcego w swoją } \\
\text { aktywność }\end{array}$ & & \\
\hline KOMUNIKACJA & & \\
\hline Niewerbalna & & \\
\hline Werbalna & & \\
\hline $\begin{array}{l}\text { Reagowanie na komunikaty } \\
\text { opiekuna }\end{array}$ & & \\
\hline $\begin{array}{l}\text { Inicjowanie komunikacji z } \\
\text { opiekunem }\end{array}$ & & \\
\hline $\begin{array}{l}\text { Reagowanie na komunikaty } \\
\text { obcego }\end{array}$ & & \\
\hline $\begin{array}{l}\text { Inicjowanie komunikacji z } \\
\text { obcym }\end{array}$ & & \\
\hline $\begin{array}{l}\text { Podążanie za wzrokiem } \\
\text { opiekuna }\end{array}$ & & \\
\hline Podążanie za wzrokiem obcego & & \\
\hline $\begin{array}{l}\text { Kierowanie uwagą opiekuna, } \\
\text { aby coś uzyskać (np. otrzymać } \\
\text { zabawkę) }\end{array}$ & & \\
\hline $\begin{array}{l}\text { Kierowanie uwagą opiekuna, } \\
\text { aby podzielić doświadczenie } \\
\text { (np. żeby opiekun spojrzał na tę } \\
\text { samą zabawkę) }\end{array}$ & & \\
\hline
\end{tabular}




\begin{tabular}{|c|c|c|}
\hline $\begin{array}{l}\text { Kierowanie uwagą obcego, } \\
\text { aby coś uzyskać (np. otrzymać } \\
\text { zabawkę) }\end{array}$ & & \\
\hline $\begin{array}{l}\text { Kierowanie uwagą obcego, aby } \\
\text { podzielić doświadczenie (np. } \\
\text { żeby obcy spojrzał na tę samą } \\
\text { zabawkę) }\end{array}$ & & \\
\hline \multicolumn{3}{|c|}{ OPIEKUN } \\
\hline \multicolumn{3}{|l|}{ ZACHOWANIE WOBEC DZIECKA } \\
\hline \multicolumn{3}{|l|}{ Uważna obserwacja } \\
\hline \multicolumn{3}{|l|}{ Odwracanie uwagi od dziecka } \\
\hline \multicolumn{3}{|l|}{$\begin{array}{l}\text { Nawiązywanie kontaktu } \\
\text { wzrokowego }\end{array}$} \\
\hline \multicolumn{3}{|l|}{ Unikanie kontaktu wzrokowego } \\
\hline \multicolumn{3}{|l|}{$\begin{array}{l}\text { Wrażliwość (zauważanie } \\
\text { komunikatów dziecka) }\end{array}$} \\
\hline \multicolumn{3}{|l|}{$\begin{array}{l}\text { Responsywność (adekwatne } \\
\text { reagowanie na komunikaty } \\
\text { dziecka) }\end{array}$} \\
\hline \multicolumn{3}{|l|}{ Nadawanie struktury } \\
\hline \multicolumn{3}{|l|}{ Zakazy i nakazy } \\
\hline \multicolumn{3}{|l|}{ Dyrektywność } \\
\hline \multicolumn{3}{|l|}{$\begin{array}{l}\text { Nadmierna kontrola, } \\
\text { ograniczanie }\end{array}$} \\
\hline \multicolumn{3}{|l|}{ Intruzywność } \\
\hline \multicolumn{3}{|l|}{ Konsekwentne reagowanie } \\
\hline \multicolumn{3}{|l|}{ Adekwatne wymagania } \\
\hline \multicolumn{3}{|l|}{ Bierność, wycofanie, unikanie } \\
\hline \multicolumn{3}{|l|}{ Wrogość, szorstkość } \\
\hline \multicolumn{3}{|l|}{$\begin{array}{l}\text { Sposoby komunikowania się z } \\
\text { dzieckiem }\end{array}$} \\
\hline \multicolumn{3}{|l|}{$\begin{array}{l}\text { Proponowane formy aktywności } \\
\text { i tematy zabawy }\end{array}$} \\
\hline $\begin{array}{l}\text { Dostrojenie tempa swojego } \\
\text { zachowania do tempa dziecka }\end{array}$ & & \\
\hline
\end{tabular}




\section{ZAŁĄCZNIKI}

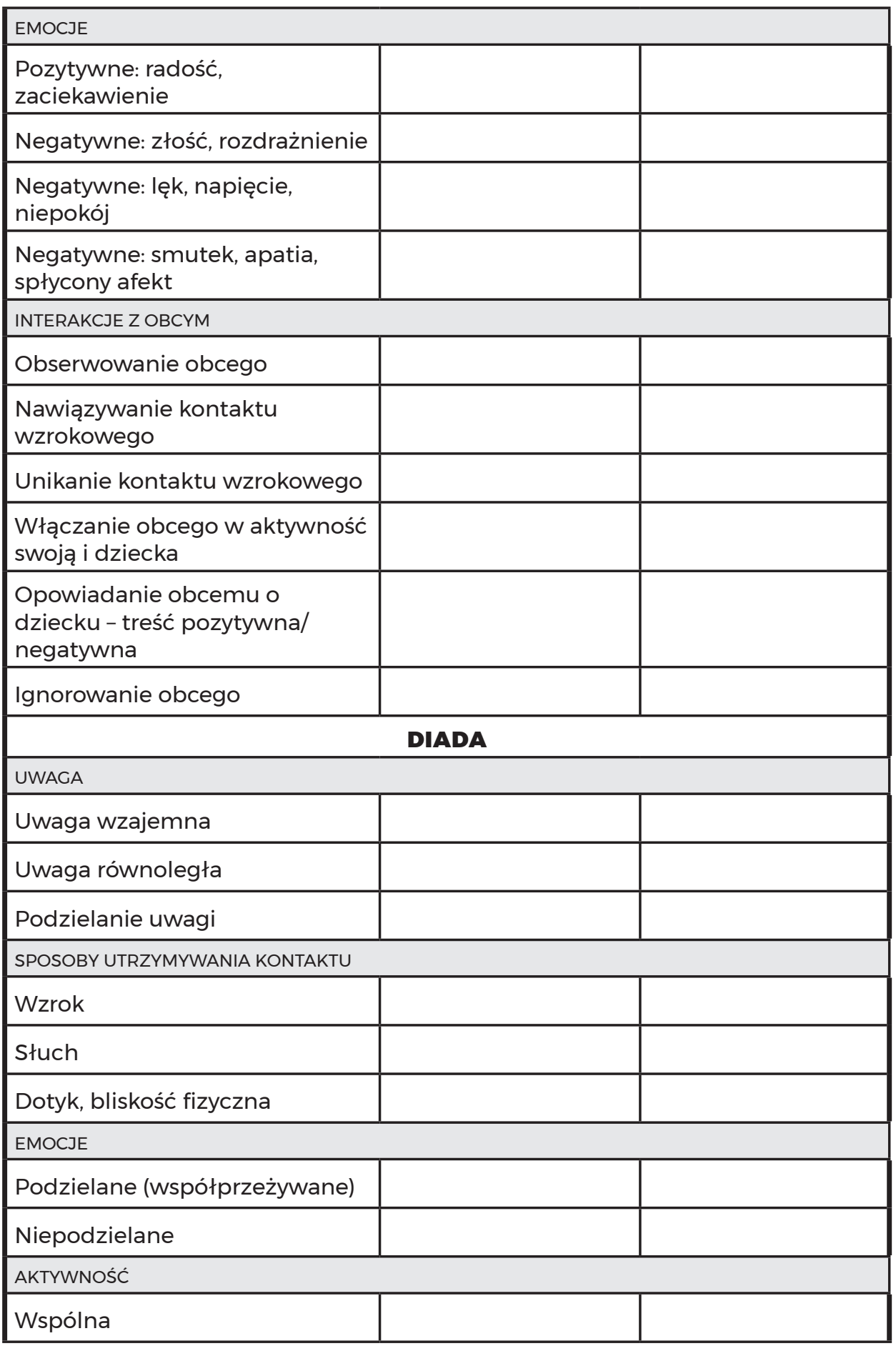




\begin{tabular}{|l|l|l|}
\hline Równoległa & & \\
\hline Kolidująca & & \\
\hline Naprzemienność działań & & \\
\hline Wspólne wykonanie zadania & & \\
\hline $\begin{array}{l}\text { Aktywność bez użycia } \\
\text { przedmiotów }\end{array}$ & & \\
\hline $\begin{array}{l}\text { Aktywność z użyciem } \\
\text { przedmiotów }\end{array}$ & & \\
\hline DOPAsowANiE & & \\
\hline $\begin{array}{l}\text { Uzgadnianie rodzaju i celu } \\
\text { aktywności }\end{array}$ & & \\
\hline Wspólne tempo & & \\
\hline Zgodność afektywna & & \\
\hline Łatwość komunikowania się & & \\
\hline Konflikt & & \\
\hline $\begin{array}{l}\text { Rozwiązywanie konfliktu, } \\
\text { negocjacje }\end{array}$ & & \\
\hline INTERAKcJe z oBcyM & & \\
\hline $\begin{array}{l}\text { Włączają obcego w swoją } \\
\text { komunikację lub aktywnośc }\end{array}$ & & \\
\hline Ignorowanie obcego & & \\
\hline pomaga dziecku/osobie/diadzie & & \\
\hline Jedynie obserwuje & & \\
\hline Aktywnie uczestniczy & & \\
\hline Ołatwia komunikowanie się lub & & \\
\hline
\end{tabular}


Dodatkowe uwagi

Dziecko:

Rodzic:

Diada:

Osoba obca:

Zakłócenia procedury obserwacyjnej:

\section{Dodatkowe pytania}

1. Czy według opiekuna dziecko zachowało się w sposób dla siebie typowy? Dlaczego?

2. Czy dorosły uważa, że zachowywał się w sposób dla siebie typowy? Dlaczego?

3. Czy według opiekuna istnieją czynniki, które mogły wpłynąć na dyspozycję lub stan dziecka w trakcie obserwacji?

4. Czy według opiekuna istnieją czynniki, które mogły wpłynąć na jego dyspozycję lub stan w trakcie obserwacji? 


\section{ZALACCZNIK B: NAUCZANIE ANALIZY INTERAKCJI DZIECKO-RODZIC}

Analiza interakcji może być nauczana na studiach psychologicznych, a także w pewnym zakresie na kierunkach pokrewnych. Jest to nie tylko wartościowe narzędzie do zastosowań badawczych i klinicznych. Może ona również znaleźć zastosowanie jako narzędzie dydaktyczne pozwalające kształtować u studentów różne umiejętności: obserwacji i nadawania znaczenia danym obserwacyjnym, używania w praktyce wiedzy psychologicznej, stosowania rygorów postępowania badawczego oraz myślenia klinicznego. Dlatego też na podstawowym poziomie mogłaby się znaleźć w programie nauczania psychologii rozwoju człowieka w ramach zajęć obowiązkowych dla wszystkich studentów, a w rozszerzonym zakresie jako przedmiot przeznaczony dla osób, które wybrały ścieżki specjalistyczne kliniczną czy wychowawczą. Poniżej znajdują się materiały dydaktyczne opracowane przez autorkę na potrzeby prowadzonych przez nią zajęć dydaktycznych na Wydziale Psychologii Uniwersytetu Warszawskiego, zarówno w ramach kursu obligatoryjnego (Psychologia rozwoju człowieka), jak i zajęć fakultatywnych w całości poświęconych analizie interakcji dziecko-rodzic. Końcowa część rozdziału zawiera dane ankietowe zebrane w grupie studentów, dotyczące ich opinii na temat narzędzia, które się poznali.

\section{Zagadnienia podstawowe}

Studenci przystępujący do nauki analizy interakcji dziecko-rodzic na poziomie podstawowym muszą znać i rozumieć przebieg typowego rozwoju w okresie dzieciństwa, znać teorie wyjaśniające rozwój i mieć podstawową wiedzę z obszaru metodologii badań psychologicznych. Zajęcia dotyczące analizy interakcji powinny być poprzedzone co najmniej 90-minutowymi zajęciami na temat obserwacji dziecka. Porównanie zachowania dziecka 
podczas zabawy samodzielnej i zabawy z rodzicem samo w sobie może być ciekawym ćwiczeniem.

Na poziomie podstawowym najlepiej pokazywać studentom nagrania dzieci rozwijających się typowo, a interakcje powinny mieć pozytywny charakter (sytuacja komfortowa dla dziecka i rodzica, dominacja pozytywnych emocji uczestników, stosunkowo wysoka synchronia czy dopasowanie). Na tym etapie warto zadbać, aby nagranie było wysokiej jakości i z małą ilością bodźców rozpraszających, które mogłyby utrudniać studentom obserwację. Najlepiej, aby odbywało się w pokoju, w którym obecne są tylko osoby, które mają być obserwowane, gdzie panuje względny porządek, oświetlenie jest dobre, ściany są gładkie i nie ma żadnych zakłóceń dźwiękowych. Obserwacja interakcji dziecko-rodzic może stanowić duże wyzwanie na początku nauki i wszelkie bodźce utrudniające percepcję obrazu i dźwięku dodatkowo sprawiają, że zadanie to staje się bardziej skomplikowane. Ponadto warto zaczynać pracę od krótkich nagrań, maksymalnie 2-3-minutowych, odpowiednio skracając ich długość, jeżeli grupa ma trudności, i wydłużając je wraz z rosnącymi umiejętnościami studentów.

Zwykle niezbędna jest dwukrotna prezentacja każdego nagrania w całości przed rozpoczęciem analizy materiału. Na początkowych etapach nauki podczas komentowania analizowanego nagrania często konieczne jest zatrzymywanie i kilkukrotnie pokazanie jego fragmentu. Następnie warto prosić studentów, aby to oni wskazywali te momenty, które są istotne ze względu na omawiany w danym momencie aspekt zachowania. Początkowo zwykle grupa pracuje najlepiej wspólnie, $\mathrm{z}$ aktywnym udziałem osoby prowadzącej, ale kolejne nagrania studenci są już w stanie analizować w małych podgrupach lub parach, na koniec dzieląc się efektami pracy z całą grupą. W ciągu pierwszych 90-minutowych zajęć zwykle możliwe jest jedynie krótkie wprowadzenie do analizy interakcji (część teoretyczna, około 30 minut), a następnie przeanalizowanie jednego 2-minutowego nagrania wspólnie i jednego w podgrupach. W rozdziale 2.1 został przedstawiony schemat analizy materiału obserwacyjnego, który warto wykorzystać w pracy ze studentami.

Spodziewanymi efektami nauczania na poziomie podstawowym powinno być: (1) rozumienie różnicy między obserwacją i interpretacją zachowania osób; (2) świadomość podstawowych możliwości, jakie analiza interakcji dziecko-rodzic daje badaczowi i klinicyście, oraz (3) umiejętność przeprowadzenia w sposób uporządkowany analizy krótkiego epizodu interakcji 
dziecko typowo się rozwijające-rodzic w odniesieniu do wybranych ram teoretycznych.

\section{Poziom rozszerzony}

Pogłębienie wiedzy i umiejętności studentów tak, aby mogli podjąć próbę wykorzystania analizy interakcji dziecko-rodzic we własnym badaniu (np. do pracy magisterskiej) lub w pracy klinicznej po uzyskaniu dyplomu, wymaga co najmniej 30 godzin ćwiczeń w sali oraz sporego nakładu pracy własnej studentów. Na wstępie od studentów należy oczekiwać biegłości $\mathrm{w}$ posługiwaniu się teoriami rozwoju typowego i przynajmniej podstawowej wiedzy o rozwoju nietypowym, a także znajomości języka angielskiego w stopniu umożliwiającym czytanie literatury specjalistycznej, ponieważ część prac jest dostępna tylko w języku angielskim. Zajęcia takie mogą być oferowane studentom, którzy odbyli już wszystkie obowiązkowe zajęcia w ramach studiów psychologicznych i zaczęli zawężać obszar zainteresowań. Ze względu na ćwiczeniowy charakter zajęć, grupa nie powinna liczyć więcej niż 15 osób.

Poza zapoznaniem się z zagadnieniami podstawowymi, spodziewanymi efektami nauczania na poziomie rozszerzonym są: (1) świadomość zalet i wad stosowania analizy interakcji w badaniach i praktyce klinicznej; (2) rozumienie różnic między podejściem mikro- i makroanalitycznym; (3) znajomość pojęć używanych w ocenie jakości interakcji dziecko-rodzic; (4) znajomość zmian rozwojowych w interakcjach dziecko-rodzic; (5) znajomość specyfiki interakcji dziecko-rodzic w wybranych grupach dzieci (np. z zaburzeniami neurorozwojowymi, niepełnosprawnością); (6) znajomość form ochrony praw osób, których interakcje zostają poddane analizie (kontrakt, ochrona danych osobowych) i świadomość problemów etycznych związanych ze stosowaniem analizy interakcji dziecko-rodzic; oraz (7) umiejętność przeprowadzenia w sposób uporządkowany analizy interakcji dziecko-rodzic w odniesieniu do wybranych ram teoretycznych, także $\mathrm{w}$ diadach $\mathrm{z}$ dzieckiem rozwijającym się nietypowo. Szczegółowe tematy, na przykład zajęć dotyczących wybranych grup dzieci, zależą od wiedzy i doświadczenia zawodowego dydaktyka oraz zainteresowań studentów. Zajęcia można rozszerzyć o tematykę skupiającą się na rodzicu, np. obejmującą wybrane grupy kliniczne.

Istnieje szereg metod dydaktycznych, którymi można posłużyć się w nauczaniu studentów z różnym poziomem wiedzy psychologicznej i różnymi 
celami edukacyjnymi. Podstawową metodą jest analiza interakcji według przyjętego schematu. Ćwiczenie to można urozmaicić poprzez uwzględnienie nagrań więcej niż jednego dziecka z rodzicem lub rodzicami (można wtedy prosić studentów o analizę i porównanie zachowań interakcyjnych dzieci i rodziców w diadach, triadach itd.). Grupę można również podzielić na podgrupy, których zadaniem będzie analiza interakcji w odniesieniu do różnych podejść teoretycznych. Wstępny etap analizy można również wzbogacić, wykorzystując dostępne narzędzia, takie jak obserwacyjne skale przesiewowe (np. Q-CHAT [Allison i in., 2008] czy M-CHAT-R/F [Robins i in., 2014], które dotyczą objawów autyzmu) lub schematy kodowania stosowane w badaniach naukowych (zob. rozdział 2.3). Użyteczną metodą jest wspólna analiza pisemnych protokołów z obserwacji przygotowanych przez studentów. Przez cały czas trwania kursu warto umożliwiać studentom swobodne dyskusje w grupie, a dodatkowo zorganizować można dyskusję oksfordzką. Przykładowe tematy takiej dyskusji to „Jakość interakcji dziecko-rodzic determinuje trajektorię rozwoju dziecka” lub „Analiza interakcji dzieckorodzic jest zbyt subiektywna, by można ją uznać za narzędzie naukowe”. Zwieńczeniem zajęć powinno być nagranie i całościowa analiza interakcji dziecko-rodzic przeprowadzona przez studentów.

W trakcie zajęć można wykorzystać Załącznik A: Kartę oceny interakcji oraz materiały zamieszczone dalej (przykładowy sylabus i literatura do zajęć, slajdy, opis sekwencji interakcyjnej na podstawie nagrania i protokół z obserwacji zabawy dziecka z ojcem).

\section{Analiza interakcji z punktu widzenia studentów}

Wśród studentów, którzy uczestniczyli w zajęciach dotyczących analizy interakcji dziecko-rodzic, przeprowadzono krótką ankietę internetową, aby dowiedzieć się, jak postrzegają poznane narzędzie. Zawierała one następujące pytania:

1. Z Pani/Pana punktu widzenia, jak trudna w zrozumieniu, opanowaniu i stosowaniu jest metoda ${ }^{23}$ analizy interakcji rodzic-dziecko (AI) w porównaniu z innymi niestandaryzowanymi metodami diagnozy, które

23 Za radą Recenzentki, Pani Profesor Marty Białeckiej-Pikul, zrezygnowałam z określania analizy interakcji mianem metody i określam ją teraz narzędziem. 
omawiane są w trakcie studiów psychologicznych, takimi jak rozmowa psychologiczna?

- Łatwiejsza

- Trudniejsza

- Stopień trudności jest podobny

2. Z Pani/Pana punktu widzenia, jak trudna w zrozumieniu, opanowaniu i stosowaniu jest metoda AI w porównaniu z wystandaryzowanymi testami, które poznaje się w trakcie studiów psychologicznych, takimi jak testy inteligencji?

- Łatwiejsza

- Trudniejsza

- Stopień trudności jest podobny

3. Jak Pani/Pan uważa, ile czasu potrzebowałaby Pani/potrzebowałby Pan, aby nauczyć się stosowania metody AI na tyle dobrze, aby móc po studiach używać jej w praktyce klinicznej lub badawczej? Proszę przyjąć, że w ciągu tygodnia odbyłaby Pani/odbyłby Pan jedne 90-minutowe zajęcia o charakterze ćwiczeniowym oraz dodatkowo w domu poświęcałaby Pani/poświęcałby Pan 45 minut tygodniowo na czytanie i zadania domowe.

- Nie więcej niż 6-7 tygodni (pół semestru zajęć)

- Około 15 tygodni (jeden semestr zajęć)

- Około 30 tygodni (dwa semestry zajęć)

- Trzech-czterech semestrów zajęć

- Ponad czterech semestrów zajęć

4. Kto Pani/Pana zdaniem może mieć kompetencje wystarczające, aby stosować w praktyce klinicznej lub badawczej metodę analizy interakcji rodzic-dziecko?

- Tylko psycholog (wymagana specjalistyczna wiedza psychologiczna i kompetencje nabywane w trakcie studiów psychologicznych).

- Psycholog, ale także pedagog lub psychoterapeuta niebędący psychologiem (wymagana wiedza i kompetencje będące elementem wykształcenia osób mających przygotowanie do pracy z dziećmi i rodzicami).

- Wszyscy wyżej wymienieni, a także lekarze, terapeuci, nauczyciele, pracownicy społeczni, socjolodzy, antropolodzy (wiedza i umiejętności mogą pochodzić z różnych dziedzin zorientowanych na badania i pracę z człowiekiem). 
- Wystarczające kompetencje mogą mieć osoby różnym wykształceniu, orientacji teoretycznej i obszarze praktyki (także niewymienione wyżej).

Uczestnicy mieli ponadto możliwość dodania własnych komentarzy.

Do studentów wysłano drogą elektroniczną zaproszenie do wypełnienia ankiety. Odpowiedzi udzieliło 25 osób. Wykresy kołowe przedstawiają odpowiedzi na pytania $z$ wielokrotnym wyborem. Większość studentów uznała, że poziom trudności analizy interakcji jest podobny lub wyższy w porównaniu z innymi narzędziami niestandaryzowanymi. Jednocześnie studenci postrzegali ją jako trudniejszą w opanowaniu niż testy wystandaryzowane. Czas potrzebny do opanowania tego narzędzia to według studentów jeden lub dwa semestry, a osobami kompetentnymi w posługiwaniu się tym narzędziem mogą być psycholodzy, pedagodzy i psychoterapeuci. W komentarzach studenci przywoływali następujące trudności: dostrzeganie szczegółów w zachowaniu i nazywanie ich, niemożność uzyskania jednoznacznego potwierdzenia, że dokonana ocena (wynik analizy) jest prawidłowa, wielość możliwych interpretacji zachowania i szybko zachodzące zmiany w zachowaniu dziecka. Ponadto studenci wskazywali, że korzystne byłoby analizowanie nie tylko nagrań interakcji, ale także interakcji na żywo oraz że aby skorzystać z zajęć, niezbędna jest znajomość psychologii rozwoju człowieka na więcej niż podstawowym poziomie lub doświadczenie w pracy z dziećmi i rodzicami. W innym przypadku zajęcia mogą być za trudne. 

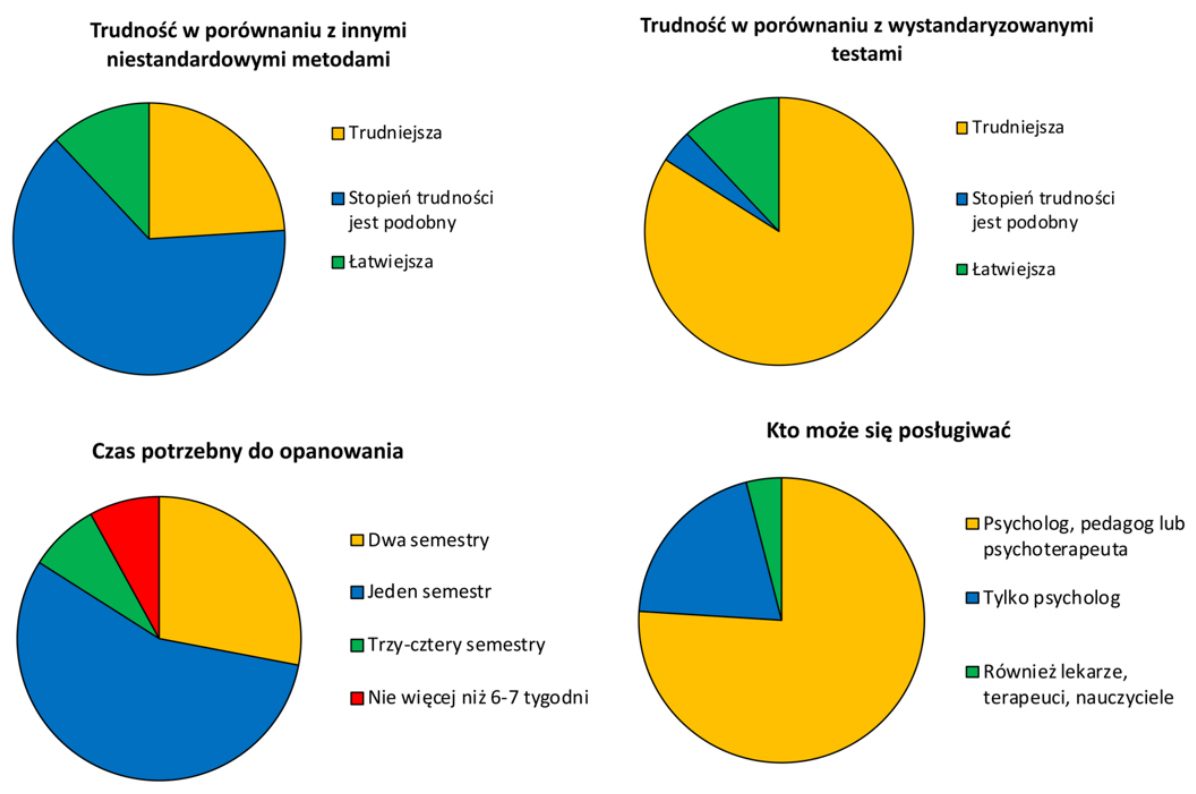

Rysunek 1. Wykresy przedstawiające wyniki ankiety przeprowadzonej wśród studentów, którzy uczestniczyli w zajęciach Analiza interakcji dziecko-rodzic.

Z punktu widzenia prowadzącej, w początkowej fazie kursu największą trudność sprawiało studentom oddzielanie obserwacji od interpretacji zachowania. Kiedy zadaniem było opisanie zachowania dziecka raczkującego w stronę matki, stwierdzali, że „dziecko chce się zbliżyć do matki”, a kiedy dziecko patrzyło na przedmiot, studenci często mówili, że „dziecko jest zainteresowane przedmiotem".

Drugim wyzwaniem była prawidłowa werbalizacja - studenci często używali nieadekwatnego słownictwa: stosowali język potoczny zamiast terminologii psychologicznej („dziecko się wścieka”, „matka zachowuje się normalnie"). Pojawiały się również określenia oceniające i etykietujące. U niektórych uczestników zajęć utrzymywała się tendencja do surowej oceny zachowań osób obserwowanych, szczególnie rodziców. Częstą trudnością w opisie zachowania dziecka rozwijającego się typowo było wyjście poza proste stwierdzenie, że dziecko rozwija się prawidłowo, czy że jest „normalne”. Jednocześnie studenci reagowali większym zaciekawieniem przy analizie interakcji dzieci z grup klinicznych. 
Studenci biorący udział w zajęciach różnili się pod względem posiadanej wiedzy i umiejętności psychologicznych oraz zainteresowań i motywacji do nauki. Kluczowym zasobem większości uczestników była ciekawość poznawcza i chęć uczenia się. Studenci mieli również gotowość do zwracania uwagi na własny stan psychiczny i jego wpływ na postrzeganie materiału obserwacyjnego, do analizowania własnych odczuć związanych z materiałem, a także własnych doświadczeń ( $\mathrm{z}$ dzieciństwa, z pracy z dziećmi) w odniesieniu do analizowanego materiału oraz do dzielenia się nimi z grupą. Studenci, którzy pracowali z dziećmi jako opiekunowie czy stażyści w różnych placówkach, mieli wyraźnie mniejszą tendencję do oceniania zachowań rodziców w kategorii dobry-zły, a ich analizy interakcji były bogatsze i bardziej pogłębione w porównaniu z wynikami pracy studentów, którzy nie mieli żadnego doświadczenia w pracy z dziećmi.

Dla studentów zaletą kursu w opisanej formie są możliwości praktycznego zastosowania zdobytych umiejętności i praca na realnym materiale obserwacyjnym, a nie na książkowych przykładach. Warsztatowy charakter zajęć pozwala aktywizować także studentów mniej zainteresowanych tematem i z niższą motywacją do nauki. Prawie wszystkie prowadzone przez autorkę książki grupy były gotowe do dyskusji tak z prowadzącą, jak i z innymi uczestnikami zajęć. Poziom zaangażowana studentów decydował o wartości kursu i efektach nauczania. 


\section{Materiały do zajęć Analiza interakcji dziecko- rodzic}

\section{Przykładowy sylabus do zajęć fakultatywnych Analiza interakcji dziecko-rodzic.}

1. Wprowadzenie do analizy interakcji dziecko-rodzic

Wstęp teoretyczny

Analiza jednego nagrania

2. Zmiany rozwojowe w interakcjach dziecko-rodzic (cz. I)

Wstęp teoretyczny

Obserwacja zmian rozwojowych na podstawie nagrań uzyskanych w ramach badania podłużnego

3. Zmiany rozwojowe w interakcjach dziecko-rodzic (cz. II)

Wstęp teoretyczny

Obserwacja zmian rozwojowych na podstawie nagrań uzyskanych $\mathrm{w}$ ramach badania podłużnego

4. Etapy analizy interakcji

Omówienie kolejnych kroków analizy interakcji

Analiza nagrania - ćwiczenie: przygotowanie surowego opisu i analiza własnych myśli i odczuć (kroki 1-2)

5. Nadawanie znaczenia danym obserwacyjnym

Analiza nagrania - ćwiczenie: opis i operacjonalizacja wybranej sekwencji zachowań, stawianie hipotez obserwacyjnych (kroki 3-4)

6. Interpretacja materiału obserwacyjnego w terminach wybranej teorii Analiza nagrania - kroki 1-5. Pogłębiona analiza całości materiału obserwacyjnego (krok 5)

7. Interakcje triadyczne

Wprowadzenie

Analiza interakcji - nagrania rodzin: interakcje w diadach i triadach

8. Specyfika interakcji z dzieckiem rozwijającym się nietypowo (cz. I zaburzenia ze spektrum autyzmu/zespół Downa/niepełnosprawność intelektualna, zespół nadpobudliwości psychoruchowej z deficytem uwagi lub inne)

Wstęp teoretyczny

Analiza nagrań

9. Specyfika interakcji z dzieckiem rozwijającym się nietypowo (cz. II dziecko głuche/niewidome/z niepełnosprawnością ruchową lub inne) 
Wstęp teoretyczny

Analiza nagrań

10. Terapia interakcji dziecko-rodzic

Metoda Parent-Child Interaction Therapy - teoria i nagrania

Metoda Wideotreningu Komunikacji - teoria i nagrania

11. Ćwiczenia - prezentacja i analiza nagrań przygotowanych przez studentów (cz. I)

12. Ćwiczenia - prezentacja i analiza nagrań przygotowanych przez studentów (cz. II)

13. Ćwiczenia - prezentacja i analiza nagrań przygotowanych przez studentów (cz. III)

14. Etyczne aspekty analizy interakcji dziecko-rodzic

Podstawowe zasady w postępowaniu klinicznym i badawczym. Informowanie i uzyskiwanie zgody na udział w badaniu. Ochrona danych osobowych.

Dylematy etyczne specyficzne dla stosowania analizy interakcji.

15. Udzielanie osobom badanym informacji zwrotnej dotyczącej interakcji Wprowadzenie

Ćwiczenia na podstawie nagrań przygotowanych przez studentów

\section{Wybrane pozycje z literatury do zajęć fakultatywnych Analiza interakcji dziecko-rodzic.}

Arias, D., Peña, M. (2016). Mother-infant face-to-face interaction: The communicative value of infant-directed talking and singing. Psychopathology, 49(4), 217-227. https://doi.org/10.1159/000447640

Aspland, H., Gardner, F. (2003). Observational measures of parent-child interaction: An introductory review. Child and Adolescent Mental Health, 8(3), 136-143. https://doi.org/10.1111/1475-3588.00061

Beebe, B., Steele, M. (2013). How does microanalysis of mother-infant communication inform maternal sensitivity and infant attachment? Attachment \& Human Development, 15(5-6), 583-602. https://doi.org/10.1080 /14616734.2013.841050

Borrego, J., Jr., Burrell, T. L. (2010). Using behavioral parent training to treat disruptive behavior disorders in young children: A how-to approach using video clips. Cognitive and Behavioral Practice, 17(1), 25-34. https:// doi.org/10.1016/j.cbpra.2009.10.003 


\section{ZAtĄCZNIKI}

Brinkmeyer, M. Y., Eyberg, S. M. (2006). Terapia interakcji rodzic-dziecko dla dzieci z zachowaniami opozycyjnymi. W: A. E. Kazdin, J. R. Weisz (red.), Psychoterapia dzieci i młodzieży. Metody oparte na dowodach (s. 210-228). Kraków: Wydawnictwo Uniwersytetu Jagiellońskiego.

Brzezińska, A., Toeplitz, Z. (red.). (2007). Problemy etyczne $w$ badaniach $i$ interwencji psychologicznej wobec dzieci i młodzieży. Warszawa: Academica Wydawnictwo SWPS.

Brzeziński, J., Chyrowicz, B., Toeplitz, Z., Toeplitz-Winiewska, M. (2019). Etyka zawodu psychologa: wydanie nowe. Warszawa: Wydawnictwo Naukowe PWN.

Czownicka, A., Zalewska, M. (1988). O obserwacji psychologicznej: zasady wnioskowania diagnostycznego. W: M. Kościelska (red.), Studia z psychologii klinicznej dziecka (s. 33-48). Warszawa: WSiP.

Fivaz-Depeursinge, E. (2008). Infant's triangular communication in "two for one" versus "two against one” family triangles: Case illustrations. Infant Mental Health Journal, 29(3), 189-202. https://doi.org/10.1002/ imhj. 20174

Kelly, J. F., Barnard, K. E. (2000). Assessment of parent-child interaction: Implications for early intervention. W: J. P. Shonkoff, S. J. Meisels (red.), Handbook of early childhood intervention (s. 258-289). Cambridge: Cambridge University Press. https://doi.org/10.1017/cbo9780511529320.014

Kildare, C. A., Middlemiss, W. (2017). Impact of parents' mobile device use on parent-child interaction: A literature review. Computers in Human Behavior, 75, 579-593. https://doi.org/10.1016/j.chb.2017.06.003

Kmita, G. (2011). Obserwacja interakcji niemowlę-rodzice. Rola mikroanalizy zachowania. W: M. Święcicka (red.), Metody diagnozy w psychologii klinicznej dziecka i rodziny (s. 43-53). Warszawa: Wydawnictwo Paradygmat.

Lorang, E., Hartley, S., Sterling, A. (2020). Physiological arousal and observed behaviour in parent-child interactions involving young children with Down syndrome. Journal of Intellectual Disability Research, 64(6), 426-433. https://doi.org/10.1111/jir.12714

Mesman, J. (2010). Maternal responsiveness to infants: Comparing microand macro-level measures. Attachment and Human Developement, 12(12), 143-149. https://doi.org/10.1080/14616730903484763

Nomikou, I., Leonardi, G., Radkowska, A., Rączaszek-Leonardi, J., Rohlfing, K. J. (2017). Taking up an active role: Emerging participation in early mother-infant interaction during peekaboo routines. Frontiers in Psychology, 8, 1656. https://doi.org/10.3389/fpsyg.2017.01656 
Piełuć, M., Fludra, M. (2010). Wideotrening Komunikacji jako metoda wspierająca rozwój emocjonalno-społeczny dziecka z trudnościami w komunikowaniu się werbalnym. Psychologia Rozwojowa, 15(1), 89-97.

Sethna, V., Murray, L., Edmondson, O., Iles, J., Ramchandani, P. G. (2018). Depression and playfulness in fathers and young infants: A matched design comparison study. Journal of Affective Disorders, 229, 364-370. https://doi.org/10.1016/j.jad.2017.12.107

Spruijt, A. M., Dekker, M. C., Ziermans, T. B., Swaab, H. (2019). Educating parents to improve parent-child interactions: Fostering the development of attentional control and executive functioning. British Journal of Educational Psychology, 90(Suppl 1), 158-175. https://doi.org/10.1111/ bjep. 12312

Steiner, A. M., Gengoux, G. W., Smith, A., Chawarska, K. (2018). Parentchild interaction synchrony for infants at-risk for autism spectrum disorder. Journal of Autism and Developmental Disorders, 48(10), 35623572. https://doi.org/10.1007/s10803-018-3624-8

Willard, A. K., Busch, J. T., Cullum, K. A., Letourneau, S. M., Sobel, D. M., Callanan, M., Legare, C. H. (2019). Explain this, explore that: A study of parent-child interaction in a children's museum. Child Development, 90(5), e598-e617. https://doi.org/10.1111/cdev.13232

Zyga, O., Dimitropoulos, A. (2020). Preliminary characterization of parent-child interaction in preschoolers with Prader-Willi syndrome: The relationship between engagement and parental stress. American Journal on Intellectual and Developmental Disabilities, 125(1), 76-84. https://doi. org/10.1352/1944-7558-125.1.76 


\section{Przykład slajdów do zajęć Wprowadzenie do analizy interakcji dziecko-rodzic.}

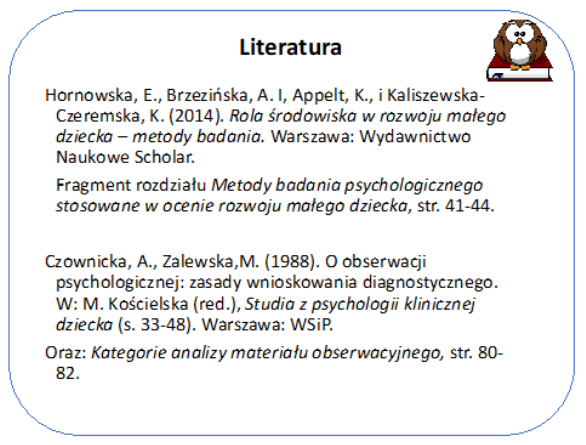

\section{Analiza danych obserwacyjnych}

1. Surowy opis wydarzeń (tylko to, co widać)

2. Analiza własnych odczuć i myśli

3. Opis wybranych zachowań lub sekwencji zachowań

4. Nadawanie znaczenia zachowaniom w terminach wybranej teorii

5. Integracja Informacji. Interpretacja zachowania w odniesieniu do wybranych ram teoretycznych

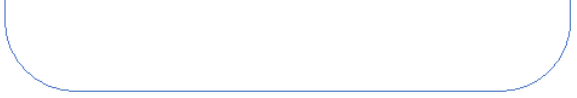

\section{Obserwacja osoby versus diady}

(] Jakie są kompetencje dziecka?

np. Czy dziecko inicjuje kontakt wz rokowy? W jaki sposób? versus

(] Jakie są kompetencje rodzica?

np. Czy rodzic odpowiada adekwatnie, kiedy dziecko próbuje nawiązać z nim kontakt wzrokowy?

$$
\text { versus }
$$

(] Jakie są kompetencje diady?

Czy diada potrafi się komunikować za pomocą kontaktu wzrokowego?

\section{Obserwacja diady Przykładowe pytania}

4. Kto prowadzi (kieruje bądź nadaje ramy interakcji)? W jaki sposób? Jak druga osoba odpowiada? Czy role się zmieniają?

5. W jaki sposób uczestnik inicjuje interakcje? Jak odpowiada na inicjatywy drugiej osoby? W jak sposób włącza ją w swoją aktywność?

6. Czy przebieg i jakość interakcji wydają się adekwatne do wieku dziecka?

7. ... Proszę zaproponować kolejne pytania.

\section{Co to znaczy, że...}

„Diagnoza psychologiczna polega na nadawaniu znaczenia zachowaniom jednostki"?

„W sytuacji stosowania techniki obserwacyjnej narzędzie tkwi niejako w osobie obserwującej"?

Czownicka, A., Zalewska,M. (1988). O obserwacji psychologicznej: zasady wnioskowania diagnostycznego. W: M. Kościelska (red.), Studia z psychologii klinicznej dziecka. Warszawa: WSiP

\section{Analiza danych obserwacyjnych}

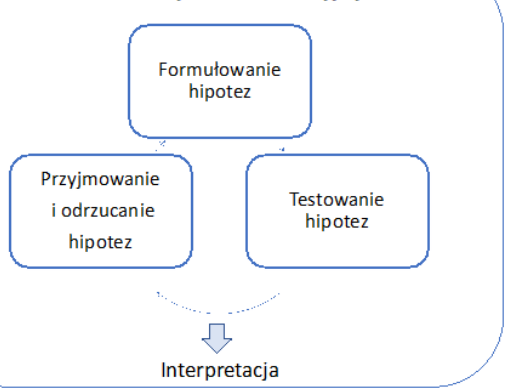

\section{Obserwacja diady} Przykładowe pytania ogólne

1. Jaki jest nastrój lub ton emocjonalny interakcji? (pozytywny/negatywny/płaski, zmienny, adekwatny/nieadekwatny, napięcie, wrogość)?

2. Jaki jest styl interakcyjny osób? (zaangażowanie, bierność, aktywna obserwacja, wycofanie, ignorowanie, wrażliwość, ułatwianie, kontrola, intruzywność)?

3. W jaki sposób rodzic i dziecko komunikują się ze sobą (kontakt wzrokowy, proksemika, dotyk, wokalizacje i mowa, wykorzystanie obiektów)?

\section{Zastosowania kliniczne}

Dlaczego w procesie diagnozy dziecka warto obserwować nie tylko zachowanie samego dziecka, ale jego interakcje z opiekunami?

\section{Zastosowania badawcze}

Na jakie pytania badawcze mogą odpowiedzieć dane uzyskane za pomocą analizy interakcji? 


\section{Wprowadzenie do analizy interakcji dziecko-rodzic}

\section{Opis sekwencji interakcyjnej na podstawie nagrania}

Osobami obserwowanymi są Julia (8,5 miesiąca) i jej mama. Obserwacja ma miejsce w mieszkaniu osób badanych, w pokoju dziennym. Na podłodze w pokoju leży mata piankowa i kilka zabawek niemowlęcych. Julia i mama siedzą naprzeciwko siebie na macie, Julia w specjalnym siedzisku.

1. Mama trzyma misia-pandę obiema rękami, nachyla się, zbliżając misia do twarzy Julii. Julia patrzy na misia (uśmiechając się), ręce ma rozłożone na bok.

2. Mama dotyka misiem twarzy Julii i szybko cofa ręce i całe ciało, zbliżając misia do swojej twarzy i zasłaniając ją nim. Julia patrzy na misia, wokalizuje gardłowo, lekko porusza rękami w górę i w dół.

3. Mama przesuwa misia w bok, odsłaniając twarz, patrzy na Julię, uśmiechając się szeroko. Julia patrzy na mamę, głośno wokalizuje, lekko porusza rękami i nieco zbliża je do tułowia. Cały czas uśmiecha się szeroko. Od odsłonięcia przez mamę twarzy, matka i córka utrzymują kontakt wzrokowy.

4. Mama zbliża misia do twarzy Julii, dotyka jej nim, cofa i zbliża go do siebie. Julia patrzy na misia i wyciąga ręce w jego kierunku, piszcząc i szeroko się uśmiechając. Julia obejmuje misia obiema rękami. Mama go puszcza. Julia przywodzi misia do siebie, przytula, przenosi wzrok w prawo, obejmuje głowę misia ustami. Przez cały czas mama patrzy na Julię i uśmiecha się szeroko. 


\section{Protokół z obserwacji zabawy dziecka z ojcem}

Osobami obserwowanymi są Filip (18 miesięcy) i jego tata. Obserwacja ma miejsce w sali zabaw. Oprócz Filipa i jego taty bawią się tam jeszcze inne dzieci z rodzicami, są również dwie opiekunki - pracownice sali zabaw. Plac zabaw jest odgrodzony płotkiem, wewnątrz znajdują się m.in. zjeżdżalnia, domek, pojazdy, grający stolik oraz liczne mniejsze zabawki. Osoba obserwująca znajduje się za płotkiem.

Filip siedzi za kierownicą samochodu i trąbi klaksonem, uśmiecha się. Tata mówi „No, co?”, na twarzy ma lekki uśmiech. Filip zerka w stronę osoby obserwującej, chwilę patrzy na nią, potem zaczyna kręcić kierownicą. Tata popycha samochód do przodu. Filip wskazuje na drzwi domku, tata je otwiera i mówi „Ale nie wjedziemy do domu samochodem”. Filip podnosi się z siedzenia, tata otwiera drzwiczki auta. Filip siada i „jedzie” dalej. Tata mówi „Ale zamknij drzwi” i zamyka je. Filip je otwiera i kręci kierownicą. Tata mówi „Trzeba zamknąc”" i zamyka. Znów popycha samochód. „Jadą” kawałek, Filip zatrzymuje się i wstaje. Tata pyta „Wysiadasz?”. Filip wysiada i podchodzi do grającego stolika do zabaw, spogląda na osobę obserwującą. Tata odchodzi kilka kroków dalej i siada na krześle, zwrócony w stronę Filipa, twarz ma rozluźnioną. Filip przez chwilę naciska różne przyciski, a kiedy pojawiają się dźwięki, uśmiecha się i przyciska coraz energiczniej. Spogląda na tatę z uśmiechem. Tata też uśmiecha się i mówi „No!”. Filip jeszcze chwilę bawi się jak wcześniej, po czym próbuje wejść na stolik. Tata mówi poważnym tonem „No, nie wchodzimy”. Filip nieruchomieje, patrzy na tatę, uśmiecha się i zdejmuje nogę ze stolika. Rozgląda się, uśmiecha, naciska elementy stolika, lekko podskakuje. Znów się rozgląda, patrzy na opiekunkę, która też patrzy na niego, i mówi „E!”, patrząc na nią. Tata podchodzi do Filipa i zaczyna się bawić grającym stolikiem, tak jak przed chwilą robił to Filip. Filip natychmiast odwraca się i pochodzi do stojącego dalej stołu z zabawkami. Zdejmuje z niego gitarę, tata mówi „O!”, podchodzi do Filipa, bierze gitarę do rąk (Filip ją puszcza) i zaczyna grać na niby, po czym odkłada gitarę. Filip wraca do grającego stolika, tata patrzy na Filipa. Filip znów podchodzi do stołu z zabawkami, bierze słuchawkę od telefonu i przykłada do ucha. Tata wraca na krzesło. Filip chwyta wieżę z Hanoi i spogląda na tatę. Tata $\mathrm{w}$ tym momencie nie patrzy na Filipa, wstaje $\mathrm{z}$ krzesła i podchodzi do wejścia na plac zabaw, szuka czegoś w wózku. Filip znów spogląda na tatę i przemieszcza się $\mathrm{w}$ stronę innych stolików, gdzie chwilę patrzy na bawiącego się chłopca. Wraca do swojego stolika, bierze lornetkę i idzie z nią 
w kierunku taty. Wkłada ją do buzi. Tata mówi łagodnie „Filipku, nie wolno do buzi". Filip odwraca się i odchodzi kawałek, lornetkę ma w buzi. Podchodzi do chłopca, który jedzie autkiem i wskazuje na niego, palcem dotykając okolic oczu chłopca. Dziecko robi gniewną minę, Filip odsuwa się szybko, minę ma poważną. Upuszcza lornetkę i wsiada na bujanego konika. Mówi „Iiiii!”, zsuwa się z niego. Podchodzi do kuchenki-zabawki, bierze garnek i patelnię, kładzie je na podłogę i siada. Rozgląda się. Zostawia zabawki i wchodzi na autko, patrzy na opiekunkę, która patrzy na niego. Tata podchodzi do Filipa, pyta "Chcesz piciu?” i podaje mu bidon. Filip odwraca się do niego plecami. Podchodzi do zjeżdżalni i próbuje wejść, tata chwilę stoi z boku, po czym mówi „Daj rączkę" i pomaga Filipowi się wspiąć. Filip z góry rozgląda się po placu, patrzy na tatę. Próbuje zjechać na brzuchu, ale zaklinował się. Tata komentuje „No i jak wyjdziesz?”. Filip w końcu zjeżdża na brzuchu. Wstaje, podchodzi do auta i popycha je w kierunku domku. Otwiera drzwi i wpycha samochód do środka. Sam też próbuje wejść. Za nim, pochylony, stoi tata. 


\section{Instrukcja do przygotowania nagrania i prezentacji własnej analizy interakcji dziecko-rodzic wraz z kryteriami oceny}

Istota zadania. Studenci mają za zadanie przeprowadzić analizę materiału obserwacyjnego. Materiałem jest nagranie zabawy dziecka $\mathrm{z}$ drugą osobą. Studenci muszą zrekrutować osoby do badania. Mogą to być dalecy znajomi czy osoby polecone przez innych studentów, którzy uzyskali zgodę na przekazanie w tym celu ich danych kontaktowych. Nagranie może zostać wykonane przez studentów lub może być dostarczone np. przez rodziców dziecka, pod warunkiem, że spełnia wymagania (poniżej). Grupa musi przeprowadzić analizę materiału obserwacyjnego zgodnie ze schematem przedstawionym na zajęciach i z wykorzystaniem ćwiczonych $\mathrm{w}$ trakcie zajęć umiejętności. Zadanie sprawdza stopień opanowania umiejętności zdobytych podczas ćwiczeń. W terminie ustalonym na początku semestru, podczas zajęć studenci: (1) przedstawiają nagranie (obraz i dźwięk), (2) przedstawiają analizę materiału obserwacyjnego.

Zadanie wykonywane jest grupach.

Czas trwania nagrania: 5 minut. Czas trwania prezentacji (analizy materiału): 20 minut (w zależności od liczebności grupy)

Nagranie. Na nagraniu widoczne musi być dziecko, osoba, z którą się bawi oraz ich otoczenie. Dialogi muszą być słyszalne. Jakość nagrania musi umożliwiać analizę materiału obserwacyjnego. Sugestia: nagranie zabawy rodzica/studenta $\mathrm{z}$ dzieckiem na podłodze, w mieszkaniu, jego zabawkami; w przypadku starszych dzieci zabawa może mieć np. formę gry planszowej. Inne możliwe aktywności, szczególnie dla starszych dzieci: wspólne przygotowywanie posiłku, wykonania pracy plastycznej (o ile jest to aktywność lubiana przez dziecko). Należy uważać, aby pomieszczenie było dobrze oświetlone oraz aby nagrania nie zakłócały dźwięki w tle, np. głośno grający telewizor. Można ustawić kamerę na stojaku lub nagrywać trzymając kamerę w ręce. Najlepiej wykonać krótkie nagranie testowe i sprawdzić jego jakość przed przystąpieniem do nagrania całości obserwacji. W razie potrzeby można przyciąć nagranie lub przewinąć.

Konieczne jest uzyskanie pisemnej zgody prawnego opiekuna dziecka na rejestrację jego wizerunku oraz wykorzystanie nagrania w trakcie zajęć dydaktycznych. Należy szczegółowo poinformować uczestników o celu nagrania. Uczestnicy muszą mieć jasność co do tego, że nagranie nie służy 
celom diagnostycznym oraz że nie uzyskają żadnej informacji zwrotnej. Nagranie służy wyłącznie celom dydaktycznym. Formularz zgody udostępnia prowadząca/prowadzący. Grupa nie może zaprezentować nagrania, jeżeli najpierw nie przedłoży zgody osobie prowadzącej zajęcia. W przypadku dzieci młodszych zgoda jest domniemana na podstawie zachowania. Od starszych dzieci uzyskujemy zgodę werbalną. Należy przestrzegać wszystkich obowiązujących zasad etycznych (zob. Kodeks etyczno-zawodowy psychologa, 1994).

TAK:

- Dziecko jest w dobrym stanie fizycznym i psychicznym.

- Dziecko bawi się z dorosłym lub innym dzieckiem.

- Dziecko znajduje się w znanym sobie otoczeniu.

- Dziecko ma możliwość bawienia się tak, jak lubi.

NIE:

- Dziecko jest w bliskiej relacji z którymś ze studentów przygotowujących prezentację (np. własne dzieci, rodzeństwo).

- Dziecko ma zaburzenia rozwoju lub choruje, rodzic ma zaburzenia psychiczne, rodzina jest w trudnej sytuacji życiowej etc.

- Rodzice oczekują informacji zwrotnych dotyczących poziomu rozwoju dziecka, zaobserwowanych nieprawidłowości czy oceny własnego zachowania.

Ocena. Wykonanie zadania jest oceniane punktowo. Maksymalnie można uzyskać 5 punktów.

\section{A. Informacje wstępne.}

$1 \mathrm{pkt}$ - Studenci dostarczyli wszystkie potrzebne informacje wstępne: wiek dziecka, czy chodzi do żłobka / przedszkola (od kiedy?) / pozostaje w domu (z kim?) / szkoły (która klasa?); skład rodziny; kim dla dziecka jest osoba, która partneruje mu w zabawie; kiedy i gdzie miała miejsce obserwacja; w jaki sposób zrekrutowano osoby badane; ew. inne ważne informacje ze względu na analizę materiału.

0 pkt - Brak lub niewystarczające informacje. 


\section{B. Jakość nagrania.}

1 pkt - Przynajmniej wystarczająca jakość nagrania, umożliwiająca dokonanie analizy materiału obserwacyjnego. Widoczne jest dziecko, osoba z którą się bawi oraz otoczenie. Słychać wypowiedzi. Brak poważnych zakłóceń, np. w postaci hałasu w tle, który utrudnia analizę materiału. Oczywiście dopuszczalne jest, że nie zawsze będą widoczne twarze obserwowanych osób, pojawi się zakłócenie w postaci wejścia osoby trzeciej czy pojedynczych hałasów w tle.

0 pkt - Słaba jakość dźwięku lub obrazu. Niska rozdzielczość, uniemożliwiająca rozpoznanie np. wyrazu twarzy osób badanych. Niedostateczne oświetlenie. Hałas w tle. Dźwięk i obraz poważnie niezsynchronizowane. Na nagraniu widać tylko dziecko.

\section{Analiza.}

3 pkt - Studenci dostrzegają wiele zachowań, także bardziej subtelnych („Dziewczynka bawi się lalką, siedząc obok mamy. Przez większość czasu patrzy na lalkę, ale kilkakrotnie kieruje spojrzenie na mamę. Manipuluje lalką, używając obu rąk. Mama przez cały czas patrzy na dziecko...”). Oddzielają własne odczucia i oceny od obserwowalnych zachowań. Analiza jest uporządkowana i całościowa. Studenci opisują poziom rozwoju dziecka we wszystkich sferach (motoryka, rozwój poznawczy, językowy, społeczny, emocjonalny), na ile jest to możliwe w oparciu o dostępne dane obserwacyjne (np. dziecko może w trakcie nagrania niewiele mówić, przez co analiza poziomu rozwoju językowego będzie skrawkowa, studenci powinni jednak to zauważyć i powiedzieć o tym wprost). Uwzględniają zachowania dorosłego/drugiego dziecka i wzajemne wpływy partnerów interakcji. W analizie podają przykłady konkretnych zachowań, które są podstawą hipotez, ocen czy interpretacji. Przynajmniej w odniesieniu do niektórych zachowań przywołują teorię, która pozwala je zinterpretować. Odwołują się do normy rozwojowej, ale nie ograniczają do kategoryzowania dziecka jako "typowo/nietypowo" się rozwijającego. Wykazują się wrażliwością i dają wyraz świadomości, że człowiek jest niedoskonałym narzędziem obserwacji (np. używają stwierdzeń typu: „zachowanie MOŻE oznaczać, że...”, „być może...”, „brakuje informacji, aby stwierdzić...”).

2 pkt - Studenci dostrzegają najważniejsze zachowania. Czasami oddzielają subiektywne odczucia i oceny od obserwowalnych zachowań. Dokonują szczegółowej analizy przynajmniej dwóch obszarów rozwoju lub powierzchownej analizy, która obejmuje wszystkie główne obszary rozwoju. 
Przynajmniej niektóre terminy są stosowane poprawnie. Niewielka liczba kategorycznych, definitywnych ocen. Próby stawiania hipotez. Może brakować przykładów konkretnych zachowań będących podstawą interpretacji lub ocen. Może brakować odniesień do teorii.

$1 \mathrm{pkt}$ - Studenci dostrzegają niewiele zachowań („Dziewczynka sama bawi się lalką"). Subiektywne oceny czy interpretacje nie są oddzielone od obserwowalnych zachowań. Terminologia niespecjalistyczna, nieadekwatna („ładnie się bawi”, „afekt wesoły”) lub stosowana błędnie. Pojawiają się o kreślenia zbyt kategoryczne, nadmiernie etykietujące lub stygmatyzujące, zbyt definitywne oceny, wnioski, których nie można wyciągnąć na podstawie danej obserwacji („Ignoruje matkę”, „Jest ufnie przywiązana”.). Dominują ogólnikowe stwierdzenia, np. „Rozwija się typowo/dobrze/normalnie”, „Bawi się symbolicznie", bez podania uzasadnienia czy przykładów zachowań.

Niezależnie od powyższych kryteriów, zadanie uznaje się za niezaliczone, jeżeli:

- studenci nie przedstawili zgody opiekuna prawnego dziecka na nagrywanie i prezentację materiału podczas zajęć dydaktycznych;

- studenci nie dysponują nagraniem;

- studenci zaprezentowali nagranie, ale nie przedstawili analizy;

- naruszone zostały prawa osób badanych lub inne zasady etyczne;

- prezentacja jest plagiatem. 
Książka przedstawia analizę interakcji dziecko-rodzic - narzędzie stosowane przez psychologów w procesie diagnozy oraz w badaniach naukowych. Celem książki jest dostarczenie Czytelnikowi podstawowych informacji teoretycznych i praktycznych, przygotowujących do używania analizy interakcji w praktyce klinicznej i w badaniach. Pierwsza część książki wprowadza w zagadnienie i przedstawia kolejne kroki analizy interakcji dziecko-rodzic oraz schematy oceny interakcji stosowane w badaniach naukowych. Druga część książki opisuje rozwój kompetencji interakcyjnych niemowlęcia oraz zawiera przegląd wyników badań nad interakcjami dziecko-rodzic w grupach dzieci z wybranymi zaburzeniami rozwoju.

Alicja Niedźwiecka - psycholog, adiunkt na Wydziale Psychologii Uniwersytetu Warszawskiego. Jej działalność naukowa i dydaktyczna obejmuje rozwój typowy i nietypowy we wczesnym okresie życia. Szczególnie interesuje się analizą interakcji dziecko-rodzic i rolą kontaktu wzrokowego w tych interakcjach.

Recenzowana ksiq̨żka jest bardzo cenna poznawczo lektura dla badaczy i praktyków, dla psychologów rozwoju i psychologów klinicznych, dla studentów, a także dla rodziców pragnacych bardziej świadomie wychowywać swoje potomstwo.

dr hab. Ludwika Wojciechowska, prof. UZ

www.LiberiLibri.pl

ISBN: 978-83-63487-53-9 